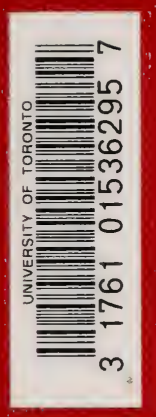





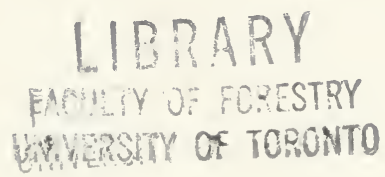

APR -81070 



MAR 201926

\author{
UNIVERSITY OF TORONTO
}

NORTH AMERICAN CERAMBYCID LARVA

\title{
A CLASSIFICATION AND THE BIOLOGY OF NORTH AMERICAN CERAMBYCID LARVÆ
}

F. C. CRAIGHEAD,

Entomologist, Division of Forest Insects Entomological Branch

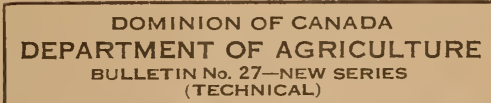

Price, $\$ 1.00$ 


\title{
ENTOMOLOGICAL BRANCH
}

\author{
Dominion Eintomologist......................Arthur Gibson \\ Associate Dominion Entomologist................. M. Swaine \\ Division of Folfest InSECts ................... M. Swaine (in charge) \\ Chimf, Division of Forfign Pests Suppression....L. S. MeLaine \\ Chimf, Division of Systematic Entomology......J. H. McDunnough \\ Chiff, Division of Field Crop and Garden Inseuts . . R. C. Treherne
}

\section{LABORATORIES}

Annapolis Royal, N.S...... Headquarters for Insecticide Investigations: Arthur Kelsall, Entomologist in charge.

Fredericton, N.B.

Forest Insect Investigations:

J. D. Tothill, Entomologist in charge.

Hemmingford, P.Q...

Fruit Insect Investigations:

C. E. Petch, Entomologist in charge.

Aylmer, P.Q........... Forest and Shade Tree Insect Investigations:

C. B. Hutchings, Assistant Entomologist in charge.

Vineland, Ont.......... Fruit Insect Investigations:

W. A. Ross, Entomologist in charge.

Strathroy, Ont......... Field Crop Insect Investigations:

H. F. Hudson, Assistant Entomologist in charge.

Port Stanley, Ont..........European Corn Borer Investigations:

H. G. Crawford, Entomologist in charge.

Treesbank, Man...........Field Crop Insect Investigations:

Norman Criddle, Entomologist in charge.

Saskatoon, Sask.......... Field Crop Insect Investigations:

K. M. King, Entomologist in charge.

Lethbridge, Alta.......... Field Crop Insect Investigations:

H. L. Seamans, Entomologist in charge.

Banff, Alta.............Mosquito Investigations:

Eric Hearle, Assistant Entomologist in charge.

Agassiz, B.C............ Field Crop and Fruit Insect Investigations:

R. Glendenning, Junior Entomologist in charge (acting).

Vernon, B.C........... Forest Insect Investigations:

Ralph Hopping, Entomologist in charge.

Fruit Insect Investigations: (Position vacant)

E. P. Venables, Junior Entomologist in charge temporarily

Victoria, B.C........... Fruit Insect Investigations:

W. Downes, Assistant Entomologist in charge.

(ENTOMOLOGICAL BULLETIN No. 23) 


\section{CONTENTS.}

P.GE

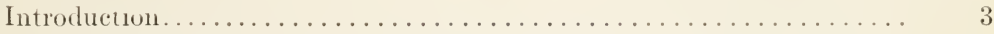

Classification of the larvae as correlated with that of the adults....... 5

Biological characteristics as correlated with anatomical structures and their use in taxonomy. . . . . . . . . . . . . . . . . . . .

Summary of biological habits................... 9

Anatomical characterization....................... 13

Brief characterization of larvae of the family Cerambycidae ........ 26

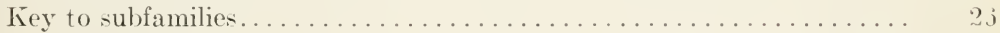

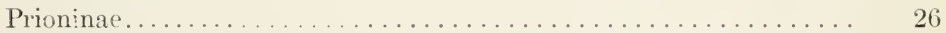

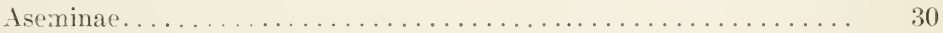

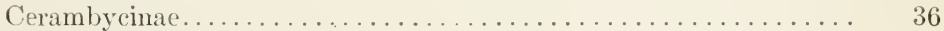

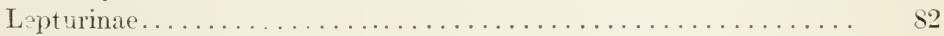

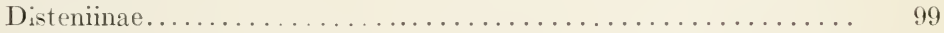

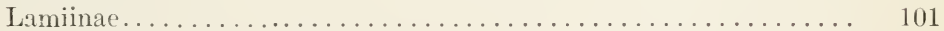

Appendix with additional species..................... 138

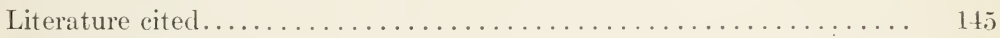

Index to species, genera and higher groups............... 147

Abbreviations used in plates and text figures................ 150

Plates................................... 1,1

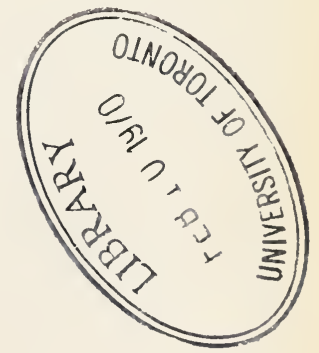





\title{
NORTH AMERICAN CERAMBYCID LARVAE
}

\section{A Classification and the Biology of North American Cerambycid Larvae}

\author{
$\mathrm{BY}$ \\ F. C. CRAICHEAD, \\ Entomologist, Division of Forest Insects, Entomological Branch
}

\section{INTRODUCTION}

The cerambycids or long-horned bectles constitute a group of insects which rank next to the scolytids in their ceonomic relation to our forests and forest products. They oceasion an annual loss of millions of clollars by their destruction, both to living trees as well as to felled trees and to lumber.

With a few exceptions, it is only in the larval stage that these insects are injurious, and it is in this stage, almost exclusively, that they are sent to the Entomological Branch with requests for identification and method of control. It is absolutely essential, therefore, that our entomologists should be able to determine these inseets in their larval stages, and know their biology; otherwise the only recourse is the laborious, lengthy and costly process of rearing, and under such conditions recommendations for remedial measures camnot be given in time to afford the necessary relief. In this bulletin there are presented tables for the identification of the larvae of all economic species of cerambycids which have any importance to forest resources. The bulletin also treats of the essential biological features necessary for recognition of these forms in the field, as well as data which must form the basis for all control or preventive measures.

The objects of the bulletin, therefore, are to describe those species of crambyeid larvae which have been reared and to give some information on their food habits and biology which will serve as a basis for a more practical discussion of the injurious aspects and control; also to indicate the systematic relationships of these larvae in the hope that these may be of assistance in the identification of the species in the larval stages and in the recognition of more exact relationships among the imagines.

Limited as this discussion is to part of the North American fauna, the difficulty of showing any broad relationships is recognized. Probably the better expression of such taxonomic positions, as shown by the larvae, will be found in groups of related genera or species where sufficient series of larvae have been available. For this reason no attempt is made to show any taxonomic relationships in the keys, but to use artificial arrangements based on the more evident characters, so as to allow the determination of the genera and species by the most expedient means. In the text the discussion of the genera expresses the writer's ideas of their relationships.

Before his appointment to the Dominion Fntomological Service. Dr. Craighead had been studying the elassification and biology of the cerambycid larvae for a number of years and had drawn up into manuscript form the deseription and discussion of a large number of species. The work was originally begun while at the Pennsylvania State College, i)ut nractically completed while at the Inited states l3ureau of lintomology. Since coming to Canada in January, 1921, lie has continued his studies, adding some Canadian species and a considerable amount of biological data to those already studied. Dr. L. O. Howard, Chief of the L nited States Bureau of Entomology and Dr. A. D. Hopkins, in eharge of Forest Insect Investigations, have given their consent to the use in this bullet in of the manuseript alrcady prepared, and for this co-operation we are indeed grateful.

ARTHYR GIBNON,

Dominion Entomologis 
Following asch deseription is given the note number of the specimens which servel as the hasis for the latral deseription either in the eollections of the Lintomological Branch, the Forest Insect collection of the United Fitates Burean of Entomelogy or the collections of the L nited states National Museum. These numbers also associate the described larvae with the reared adults and the hological notes. In the case of specimens having no number, the data on the label within the vials are noted.

since the following material and observations on hosts and habits have heen ohtained from the sources mentioned above and since many of the ol servations on the more common species have been duplicated over and over again hy a number of men associated with the institutions mentioned, it would repuire considerable space to refor to these in detail. It has, therefore, secmed anlisable to mention the names of observers only in cases of rarer species or where special studies or unusual recorels were made. By far the greater part of these records were made by A. D. Hopkins, J. M. Swaine, Ralph Hopping, J. I. Wobh, II. F. Burke, II. F. Fiske, T. E. Snyder, and the author.

fereral cntomologists in other institutions have made special efforts to assist in this work and to secure larval material and biological data, notably Mr. A. B3. Champlain, of the Bureau of Plant Industry, Harrisburg, Pennsylvania, whose ficld observations are especially detailed and accurate, and to whom the writer is indebted for a very large amount of data. Mr. J. N. Knull of the same institution has likewise given much assistance.

Mr. Crorge Dimmock kindly turned over to the United States National Museum his entire collection (part of which had been accumulated by the late Mr. Frederic Knab), consisting of many species and excellent biological notes, that it might be incorporated in this contribution.

Mr. E. Rosenberg, of Copenhagen, Denmark, kindly sent to the United States National Musem considerable material representing the European fallita.

The writer also wishes to express his appreciation of the assistance given by Dr. E. A. Schwarz, particularly for his many suggestions concerning the systematic position of these insects, and for reference to literature and interesting biological observations.

The photographs of larvae have been made by Mr. H. B. Kirk; the writer is much indebted to him for the care and pains taken to show the characteristics which have special significance. In several cases the full details could not be brought out because of the poor preservation of the material available.

The drawings have been made by Miss Esther Hart and Miss Mary Carmody, both of the United States Bureau of Entomology. Mr. A.B. Champlain has irawn the diagrammatic figures illustrating the pupal cells.

The adults reared from these larvae have been determined by Mr. II. S. Fisher, and the dipterous parasites by Mr. C. 'T. Greene. Mr. Fisher's determinations were largely made previous to 1918 , when the manuscript was outlined, and for this reason are not in all cases the nomenclature accepted at present. However, it was deemed best not to bring the names up-to-date without Mr. Fisher's authority. 


\section{CLASSIFICATION OF THE LARVAE AS CORRELATED WITH THAT OF THE ADULTS}

A review of the many schemes of chassification based on the characters of the imagines alone shows a great variety of systems and wide diversity of opinion among the different systematists. This variation of opinion is no doubt due to the many distinctive anatomical structures presented by nearly all genera and even species, the systems of classification resulting being merely the authors' various conclusions as to what particular characters are conceived to be fundamental.

Schiodte in 1863-186t (39) ${ }^{1}$ published a classification of the achult cerambycids of the Danish fauna, introlucing $n \times w$ characters and a new system. The primary divisions were basad oa the mouth structures. He discussed tha work of previous writers on this group, siating that they had gradu tlly worked away from the fundamental characters (mouth structures) and thit they laid too much stress on secondary modifications. S'chiodte also gives an admirable discussion of the relation between the types of mouth structures and the form and habits of the adult insects.

Some years later, 1876-18S3 (31) Schiodte published his unexcelled papers on the larval structures of certain European coleoptera, including the cerambycids. In these studies he corroborates entirely the conclusions on which his former classification of the adults was based, and shows that both stages can be correlated in a natural system. Here, again, he uses head structures as fundamental. This was the first and only attempt to correlate the larval and adult characters. It constitutes a most remarkable piece of work, showing profound studies into the smallest details of structure. In 1881, Ganglbauer (12) complementarily reviewed this work and deplored the fact that it had been so neglected by other systematists.

That in the formation of natural systems of classification importance should be attached to the consideration of all biological stages and factors is generally conceded but by no means widely adhered to. Fabre (9) in chapter 7 of "The Hunting Vasps," says, "It is no use telling me that this or that species has so many joints on its antennae, so many nervures to its wing, so many hairs on a region of its belly or thorax; I do not really know the insect until I am acquainted with its manner of life, its instincts, and its habits."

Tutt (33) in discussing the classification of the lepidoptera says: "No scheme based on a single set of characters belonging to only one stage of an insect's existence could possibly be only approximately perfect;" and discussing modification, he goes on to say: "it follows that no scheme of classification that is not founded on a consideration of the structural details and peculiarities of the insects in all their stages can be considered as really sound or as founded on a natural basis. It is also evident that the results of the various systemswhether based on oval, larval, pupal or imaginal characters - must be compared and the sum total of evidence brought together if a satisfactory result is to be obtained."

While studying these larvae the author avoided as much as possible, consideration of the adults, hoping thus to be free from any bias resulting from a knowledge of their systematic position and therefore to be able to perceive and express more clearly the true larval relationships. Iater in the preparation of the manuscript various systems of adult classification $(1,4,11,13,17,19,20$, and 30) were reviewerl ancl often the scheme of this or that systematist is referred to as agreeing with an arrangement based on the karvae. It is hoped that such a discussion will aid in the future classification of this family and in

\footnotetext{
1 Numbers in parentheses refer to "Literature cited"."
} 
the formulation of a more natmal systom. When a erertain adult shows affinities fowarels two eromps or eremera amel the larval charareters show rear affinities to one of these, it certamly would lo logical to eonsieler that the true position of the arlult was imlicated hy these harval characters.

Is an example of many instances in which the larval and adult rharacters

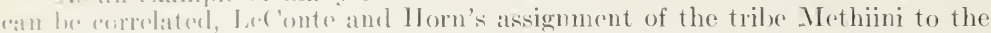
laminan may be taken. A study of these larvae elearly shows them to be the armberime trpe, and incerel later systematists have placed the adults in the smb-family of Ceramberine. Again and again in rearing unidentified larvae it las lesen pessible, from a knowledge of their strueture and habits, to predict vere aceurately the systematic position of the adults which will be reared therefrom. All of this goes to show that a certain correlation exists.

In these larvae a relatively snall number of characters or modifications of these characters have been found available for use in the classification. Some larvae can be immodiately recognized by a striking peculiarity comm on to it alone, but the great majority are to be recognized only by certain combinations of characters. The same character may be of only specific value in one subfamily, and in another subfamily it may characterize all the species. It would he pesible by a single or a few characters to place a species or genus almost anylhere, but the position given is that suggested by the greatest number of points in common, both anatomical and biological, the latter to a limited rxtent.

It is not proposed definitely to erect a group or genus by the present study, but to indicate and suggest the affinities between the species or larger divisiors and to let the adult systematists adopt such suggestions if they can be used. For instance, such genera as Plagionotus, Calloides, Cyllene, and Arhopalus are all so intimately related by larval structures and biological habits that it is imposible to separate them generically when the genus contains more than one specios. Again, such a genus as Elaphidion shows three very distinct groups of larval structures which are likewise supplemented by the habits. Hylotrupes bajulus is in no respects similar to Hylotrupes ligneus and $H$. amethystinus. Throughout the text such relationships are suggested.

Certain structures are subject to great modifications in larvae living in rlfferent environments. So striking are these modifications that closely related larvae often seem quite different, ard on the other hand, widely separated forms superficially may appear almost identical. By the elimination of such characters and the use of others which are more constant it is believed that a good hasis for classifying these larvae can be made.

Those larval characters considered as showing the relationships of the subfamilies are based on the form and structure of the head; for although the habits and enviromment may differ as widely as do those of herbaceous root feeders from those of borers in the living trunk, or those of bark feeders from cither, these head characters are searcely altered.

such characters being used as a basis, the larvae of the Cerambycidae studied by the writer may be divided into six subfamilies, namely, the Prioninae, Iseminae, Lepturinae, Cerambycinae, Lamiinae, and Disteniinae. It seems of little conscquence whether these groups are regarded as of equal rank or whether "crtain of them are considered as constituting higher groups, with the exception of Disteniinae, which probably should corstitute an entirely separate family. It is certainly possible to find a more gradual transition between any two of the first four of these subfamilies than between any of these and the Lamiinae. Un such a basis two large groups can be made. On the other hand, the Cerambycinae, in clypeal and mandibular characters, are set off quite distinctly from any other cerambycids, although in the tentorial structure they are similar to the Prioninae, and in many ways such genera as Opsimus and Oeme suggest connections with the Aseminae. Distenia will be discussed in more detail in a joint paper with Dr. A. C. Boving, where all the coleopterous families are 
considered. The adults of the Aseminae are often classified with those of the Cerambycinae. Through such genera as Llochaetes and Necydalis the Lepturinae cannot be sharply separated from the Aseminae. It would be possible from a majority of the characters to separate Prioninae and Cerambycinae into one group, and the Lepturinae and Aseminae into another. Because of interrelations and the absence of definitely connecting forms for the present the cerambyeid larvae are regarded as divided into the six subfamilies previously named.

The family Spondylidae is here included in the cerambycids. Only the larvae of Parandra have been seen, and these from their larval characters cannot be considered as other than prionines. Larvae of Spondylis have not been studied, but judging from the descriptions of the European species they agree in all respects with those of the Aseminac.

\section{BIOLOGICAL CHARACTERISTICS AS CORRELATED WITH ANATOMICAL STRUCTURES AND THEIR USE IN TAXONOMY}

It is quite evident, from even limited observations of the food habits of the cerambycid larvae, that in widely separate species and genera which live under the same environment or have similar habits there exists a striking parallel modification of certain morphological features. In the author's experience this was the source of serious confusion in field determinations before the fundamental anatomical characters on which the larger groups are based were recogn zed.

This parallel modification under similar habits and environment is found not only in the larvae but in some adults as well, suggesting that structures (more particularly form) in the adult may be modified through the influence of habit and environment on the larva. Evidence of this has been found in experimental rearing in such characters as size and colour pattern, and observation in nature suggests that it may be carried even further.

Dr. Hopkins (16) has admirably discussed parallel modifications and physiological characteristics in the Scolytoidea in relation to the taxonomy of the adult beetles. His statements are certainly borne out by all the writer's observations in the Cerambycidae, which are to the effect that the same habits are paralleled through various species and groups of all subfamilies; that together with these paralleled habits appear similar anatomical modifications in widely different groups; and that the food habits alone will not afford a natural arrangement of the imagines, but that there are certain of these physiologieal characteristies which do serve as a guide to specific or generic distinctions.

such paralleled food habits appear in all subfamilies of the cerambycid larvae and such habits or environments show many corresponding developments of the larvae in form and in the armature and texiure of the body integument.

One of the most eonstant correlations is that between the form of the larva and the particular condition under which it feeds. This is even subject to change in the same larva when, as it matures, it takes a different portion of the tree in which to feed. There are many species feeding between the bark and wood during the entire larval development, as those belonging to the genera Pachyta and Rhagium in the Lepturinae and Plectura and many speeies of Liopii in the Lamiinae. All of these larvae are of very depressed form, especially if they live under the bark before it has started to decay. Many species feed under the bark during about half the larval development and diring this time maintain the characteristic depressed form. When, howerer, they enter the wood, they begin to assume a more cylindrical form as in the ease of Monochamus. Strictly wood-boring forms are always cylindrical, as represented by Neoclytus of the Cerambycinae; most of the Prioninae; Centrodera of the Lepturinae ; 
and l'lectrorlera and Ecymses of the Iaminas. Those which pack the frass tightly hehinel them are shorter and more robust, as Veoclytus, or if the mines are more open the larva is more chongate, as represented by chion, of the Ceramliverinase, and fiose of the laminane.

Tlus (orrelation hetween form and enviromment ean be shown further in those lanvare which foed in the centere of branches, as the gircllers, or those feecling in the pith of lurbaceous stalks. When so feeching and expelling the frass the larval nume is conseguently restrieted in diameter but free and open along its axis. Furh larvae are always olongate, slender ancl eylindrical, as illustrated by Elaphidion villosum, E. subpubeseens, and $E$. tenue of the Cerambycinae, and Ii,ppopsis. Itaxia, and Oberea of the Lamiinae. Elaphidion villosum represonts an anketation only in the general cylindrical form, but a progressive derelopnent of better adaptation is shown in E. subpubescens. Hippopsis, and ()bere, in which the ampullate have become very abruptly projecting and the intersegmental skin of the abdomen very long, affording and allowing rapid movement in the larval mines. Still further is this earried by Oberea, in which the prothorax and ampullae have become asperate.

Elaphidion subpubescens and related species and species of Oberea have the common habit of expelling the frass through a straight series of small holes along the stem. The work is so similar in all that often it cannot be distinguished gencrically exeept by an examination of the surface of the gallery for marks make by the acutely-pointed mandible of one and the obtuse gougerodged mandible of the other.

In several of these genera in different subfamilies the larvae ean searcely be distinguished from one another except by an examination of the contrasting types of head structures.

In the foregoing species, representing more specialized habits, the adults are slender eylindrical forms, a fact which certainly would seem to have some correlation to the larval habits.

Another example is afforded by the armature of the ampulla and pronotum. Although the surface of these ampullae closely adheres to a certain type in each subfamily, as granulate in the Cerambycinae or tuberculate in the Lepturinae and Lamimae, a general well-marked tendency exists for the ampultae of all those species which attack living trees to become asperate (probably produced to afford better adhesion to the wet surfaces encountered under such conditions.) This is especially emphasized if the species of the genus are predominantly live-wood feeders. Among the Cerambycinae no typical case exists, but a velvety pubescence is developed in Nylotrechus and becomes asperate pubeseence in $\mathbf{X}$. aceris, which attacks living maples (Acer spp.). Leptura nitens, working in the living bark of chestnut (Castanea), has developed asperities on the tubereles of the ampullae. Among the Lamiinae are many species which attack living trees. Goes, for instance, includes six species, five of which have a finely asperate pronotum and more clistinctly asperate ampullae and all

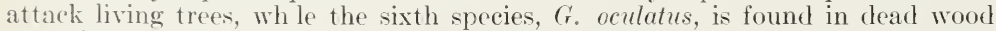
and the ampullae are glabrous, while the pronotum is asperate to velvety pubeseent.

The genera saperda and Oberea show the highest development of such armature. In the species of these genera the asperities of the pronotum are large, sharp, and recurved, afforting an excellent device for gripping the side of the wet, sapry mines. The ampullae likewise are set with sharp, erect, chitinous points.

Acanthoderes contains four species of which the larvae are known. This is typically a genus of decayed-wood feetlers and the ampullae are glabrous, shining; but one species, A. morrisit, attacks living gum trees (Nyssa sylvatica) and the pronotum and ampullae show distinct velvety to asperate pubescence.

The body integument and hairs are structures which are subject to considerable variation, flepending on the environment. Thus those species which 
bore in dry, hard, seasoned wood have a thin integument, often granulate, and the body hairs are fine and silky, such as Iylotrupes bajulus, Smodicum, and Obrium of the Cerambycinae, Necydalis of the Lepturinae, and IItoemis of the Lamiinae. Those species which inhabit soft, moist, decaying wood have a tough, shining integument beset with coarse stiff hairs, as many Prioninae, many Lepturinae (notably Anthophilax, and Acanthoderes and Itoplosia of the Laminae. All intermediate degrees oceur together with intermediate conditions of decay and moisture content of the wood.

The legs, like the ampullae, are more strictly subfamily variations of certain systematic value, yet some significance must be placed in the fact that the Lepturinae, which show them more strongly developed, are predominantly decayed-wood feeders, constructing mines of a greater diameter than the body, in which case the legs would be of more value in locomotion and the ampullae of less value. The same is true of the Prioninae, while in the Cerambycinae, although legs are usually present, they are absent or represented by only minute spines in those genera which feed consistently in solid dead wood in close-fitting burrows; thus they are very minute in Neoclytus, and in Nylotrechus they are absent.

The foregoing modifications of anatomical characters show that in deciding the taxonomic position of the genera and species of these larvae a knowledge of the biological habits is necessary in order that too much significance be not attached to conspicuous but easily modifiable characters, developed under similar environments.

On the other hand, many of these habits or physiological characteristics are of great use in the identification of species. Some are so characteristic as to identify a certain species immediately, while others that are paralleled must be considered in connection with the anatomical structures. For example, the peculiar pupal cells of Oeme immediately distinguish this genus from all other cerambycids, as do also the pupal cells of Arhopalus and Rhagium. The habit of girdling twigs, however, is peculiar to quite a few genera; if the larva is a Xylotrechus it can be immcdiately identified as $X$. quadrimaculatus, as this is the only known species with such habits in the genus; but if the girdled branch has a series of small holes through the bark the larvae concerned are those either of certain species of Elaphidion or of Oberea, in which cases the larvae must be examined for proper identification of the genus and species.

\section{SUMMARY OF BIOLOGICAI, HABITS}

Under each species a short discussion of such food habits or biology as will asisist in recognition of the insect is included. To present in a more comparative manner these habits the following resume is given.

Although the adults are not discussed in this paper, a short aceount of their habits may furnish a proper introduction to the succeeding paragraphs relating to the larvae.

Most of the adults are short-lived. They emerge, copulate, lay their eggs, and die in from a few days to several weeks. The males die much sooner than do the females. Prionine adults have been kept in eaptivity from 30 to 40 days, doing no feeding. The lamiines often live this length of time feeding daily.

Feeding by the adults is confined almost exclusively to the Lepturinae and Laminae. A few cerambycine adults, as Batyle spp., ('yllene robiniac, and Euderces spp., also have been observed to feed. The food of the adults consists of pollen, leaves, the bark of tender twigs, or the fruiting pustules of certain fungi. The species of Leptura and the few ceramby eines are pollen feeders. On bright sunny days the former (Leptura spp.) congregate in large numbers on the flowers of specially favoured plants. They are the most active ceram- 
liferels amel asily disturluel. When so disturbed some take flight quiekly, while others fall amel conceal themselves in the ground litter. Although a few lamimes have been moted ating pollen, they prefer green cellular tissue. Some

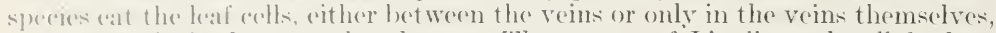
and others the lark on tender shoots. The genera of Liopii nearly all feed on the fruting pustules of bark fungi, as the chestnut bark-canker (Endothia purasiticu).

such fording usually proceeds and continues through the oripositing period. Inder such comlitions the life of the adult is greatly prolonged. As contrasted with the species of Leptura the lamines are more retiring or shade-loving, and many are active only at night.

No species are known to hibernate except in the pupal cell.

The eggs are laid in a few simple ways. By far the great majority of adults mercly place them under crevices of the bark, where they are concealed as much as possible. The prionines, which have strong ovipositors, often insert them deep into the soft wood or (e.g., Prionus, Pl. XXXVI, fig. 1) into the earth at the base of the tree on which the larvae are to feed. Some forms take advantage of the entrance burrows or emergence holes of scolytids. A few species that attack dry wood from which the bark has been removed place the egg in season checlis (Hylotrupes bajulus) or rarely lay them conspicuously on the surface (Chion cinctus). Herbaceous stem feeders and those attacking twigs often place the egg in the axil of a leaf petiole (Elaphidion spp.). The only specialization in ovipositing has been found in the lamiines, and in this group all species that have come under observation gnaw a hole or egg scar (often quite conspicuous through the bark and insert the egg into this scar. Pl. XXXVI, fig. 3). This varies little except in size, in which respect it is usually dependent on the size of the adult and the thickness of the bark. Two genera, Oncideres and Oberea, are known to girdle twigs for the purpose of ovipositing. The former lays the egg in the girdled portion, the latter in the living portion just beneath the girdle.

A certain preference has often been noted in some species for the underside of a $\log$ (lying on the ground), while others invariably will take the upper side on which to oviposit. The eggs hatch in from a few days to thirty days.

A rather constant correlation exists between the size of an adult and the length of the larval life, throughout the northern part of the temperate zone. A few species have several generations or an overlapping of generations each Year, such as those of ('yrtinus, Atimia, and Hyperplatys. A few larger species, as . Tylotrechus colonus, that feed in dead wood, also have a complete and partial second generation each year. Farther south many dead-wood feeders have an overlapping of generations. The usual life cycle is completed in one year. In other species it is extended to two, three, or even four or five years, as in Prionus and some species of Croes. Larvae of many species, especially those the adults of which appear early in the spring, mature by late summer and pass the winter as pupae or adults. Those species living as larvae two or more years do little or no feeding the last year, but after constructing a pupal cell in the late summer remain dormant until the metamorphosis takes place.

The regularity or irregularity of emergence and development shows some diversity. From a brood of Nylotrechus colonus developing from eggs laid during a single week in June adults appeared that September, from June to september of the second vear, and a few appeared early the third year. On the other hand, species such as Cyllene pictus will emerge, lay eggs, and the adults disappoar in two weeks. The resulting larvae develop regularly, the entire brood transforming to pupe within a week (in the fall) and emerging the next spring within a few days. The same is true of Neoclytus capraea and others.

Cerambycid larvae can be found in a variety of wood conditions, from living trees to thoroughly decayed logs, and from dry to almost saturated tissue, but each species is dependent on a very exact condition to produce the 
normal development. This can be well illustrated by a gradually dying tree or slirub where each stage of deterioration will have its particular species. Some requile freshly-cut wood (Cyllene pictus), others wood which has seasoned for several months or a year, and for others the wood must have been dead some time and have been lying on the moist ground. Again, the condition of a tree which died or was cut during the growing season differs from that of one which died or was cut during the dormant season, so that it is preferred by eertain species in the one case and by certain other species in the other. Old pine rafters of buildings seasoned for years are suitable for Hylotrupes bajulus, while many species of Leptura require very wet dead or decaying wood in situations where it is not subject to dessication. Many larvae are very sensitive to changes of humidity. Placing an infested branch in a dry room will prolong the larval existence of some species, several to many years, or, in the case of moisture-loving forms, quickly prove fatal. Those species breeding in living trees (Goes) will soon die if the tree is cut before the larva is mature. ()n the contrary, Callidium antennatum, requiring dry seasoned pine logs (Pinus), can be reared in freshly-cut wood, but the resulting adults are far below normal size and the life cycle is greatly lengthened.

It is difficult to elassify the many ways in which the larvae feed, since many species at different periods of their development acquire habits that in others obtain throughout the entire life-cycle. In arborescent plants certain species feed entirely in the outer scaly bark, as Encyclops and Microclytus; others mine entirely in the bast and even pupate there, as Acanthocinus, but require dead bark and enter the inner layers of the tissue. Again, there are those that feed only beneath the bark, and pupate there (Rhagium) or mine beneath the bark, searring and feeding on the wood (many species). Such feeders may pupate either in the bark, between the wood and bark, or in the sapwood. With such forms the thickness of the bark usually regulates the position of the pupal cell. The presence of bark is necessary for the early stages of nearly all species, although such forms as Neoclytus capraea (Pl. XXXV) in dead wood, or Goes (Pl. XXXII, fig. 1) in living wood, use it only as a protection for the young larvae, which almost immediately enter the wood and feed in the wood through the entire development.

A particular portion of a tree is often selected exclusively. Certain species feed only in the twigs, as Dysphaga; others attack the larger branches, the main trunk, the base, as Mallodon, or the roots, as Prionus and Distenia. Some species prefer the heartwood, as Eburia, and others live only in the sapwoot.

Among root feeders are those which attack the living roots, eating only the bark in early stages and later often completely hollowing the root, as Prionus; and those which mine between the bark and wood of dying or dearl roots, as Distenia. Some root feeders, as Prionus and Tetiaopes, burrow extensively through the ground. Crossidus and Mecas (Pl. XXIIII, fig. 2) feed in the base and roots of shrubby or herbaceous plants, sagebrush (Artemisia) and wild aster (Aster) and usually pupate in the hase of the stem.

A few genera of the Lepturinae (Anthophilax, Gaurotes, and Pachyta) that mine in very decayed wood, or between the bark and wood, just before pupating bore out of the $\log$ in which they are feeding, fall to the ground, and pupate in the soil and leaf molrl.

Certain species may be said to feed almost exchusively in the pith of the stem, as many girdlers of twigs, or Desmocerus in the base of sambucus.

A very characteristic mode of feeding is to be found in the twig-girdlers. This habit sometimes appears among unexpected genera, i.e., where the habits of the other species are quite different. In the genus, Oncideres, the adult girdles the twig. The girdling done by the larva may be either for the purpose of proviling dead wood in which to feed, or to cause the branch to drop to the ground after the larva has finished. In the former case (Xylotrechus 4-maculatus) the egg is laid near the point of cutting, the young larvae feeding beneath 
the hark, then entering the woorl, anel by coneentric mines in one plane cutting all hut the outer strands of wook. In this case it then proceseds to burrow up the stem, which som hreakis off. Quite frequently the limb breaks before the larvat has started to mine the branch, in which case the larva is killed. Elaphidiun villosum cuts the twigs in the same manner, but just before pupation, after it has hollowed the twigs from the terminal bud down to the point of chavage. I'urpuricenms axillaris has beren fomnd working like E. villosum. Another type of girdling is characteristic of Oberea spp. and Elaphidion submuluesens (Pl. NLII, fig. 3) and related species. The larvae start mining down the small twigs of living trees into branches from one-fourth to one-lualf inch in climeter. All along the stem a series of round holes, in a straight line, are mide through the hark from which the frass is exuded, and at irrogular intervals that portion of the branch eaten is eut off from the inside. In Oberea and in one species of Elaphidion the cut is made at right angles to the axis around the inside of the stem. In other species of Elaphidion this eut is very oblique or T-shaped (Pl. XLII, fig. 5). Pupation may take place in a section eut off or in the hasal section which is still green. Ataxia sometimes girdles branches in like manner.

I few spoceies feed in lerbaceous plants, chicfly composites, hollowing out the eentre of the stem and transforming in the base.

The attacks of several species of Saperda in twigs cause swellings or galls (Pl. XI.I.) S. obliqua forms a gall at the base of Alnus, and Desmocerus piperi a very large swelling at the base of Sambucus. Nylotrechus aceris forms a gall on the trunks of young red maple trees (Acer rubrum).

The dry, hard cones of Pinus attenwata are eaten by Paratimia; and the sceds of mangrove (Rhizophora mangle) by a species of Leptostylus and by the larva of Ataxia sulcata. A species of Lepturges, L. spermophagus, has been taken feeding in the seeds of cowpeas (I igna) from Mexico.

Poring dust or frass (Pl. XL, figs. 3-5) produced by the larvae in feeding is of two sources: (first) that passed through the digestive tract, and (second) that which is not eaten. The former is very fine and powdery, usually in small pellets; the latter is composed either of short flaky chips or of fibrous shreds. 'T he shreds are produeed by acute mandibles and the flakes by rounded, gougerlged mandibles. They are often quite characteristic for a species or group. This frass may be either packed tightly behind the larvae, as in the case of true wood-borers, as Smodirum, Neoclytus caprea (Pl. XXXV) and Ebmria, or less tightly packed and the mine open for a greater distance behind the larvae. Again, it may be entirely extruded through a small hole, usually the point where the rgg was laid, as in Cyllene (sens. lat.), some species of Elaphidion, Goes (I'I. XXIII, fig. 1), etc.

As intimated before, pupation may take place in the bark, under the bark, in the sapwood, in the heartwood, in the base of stalks, or in the gromnd. Just as variable are the types of pupal cells. The simplest type is an oval enlargement at the end of the larval mine. If the frass is packed close behind no harrier is ereeted, but in more open galleries a heavy wad of frass is tightly packed lehind the larva before it pupates. Sometimes such a warl is placed both in front and behind the larva (Pl. Xl.II, fig. 4). Where one wad is used the larva either turns and faces this wad so that the adult may chew out through it, as in Romalemm (Pl. XLIII, fig. 2), or the adult gnaws the exit hole through the wood, as in Goes (Pl. XLIII, fig. 3) and many other forms.

species feeding between the bark and wood may go into the wood and form a long, curved pupal cell which ends blindly. In this case the larva turns and constructs a wad of frass in front of it (Molorchus) (Pl. XLII, fig. 1). The adult gnaw through this plug and also through the bark, or the bark may have been previously opened by the larva (Pl. XLII, fig. 7, Cyllene); the wad in this ease being the only barrier to the outside. A short burrow may be made into the sapwood and the plug placed at the edge of the sapwood and protrude (Pl. 
XLII, fig. 9) as in Acanthoderes. Again, a U-shaped cell is often made which may be plugged at one end, as in Monochamus (Pl. XLIII, fig. 1) or at both ends, as in Eupogonius. Bark-feeding species which do not enter the wood may construct an oval cell of nest-like appearance, as in Rhagium (Pl. XLII, fig. 6), having a surrounding wall of shredded frass, or merely an oval cell scarring the sapwood and having no wall, as in Cyrtinus (Pl. XiII, fig. 2).

A few species pupating in the ground make an oval cell of earth hetd together by a secretion of some kind, as in Prionus (Pl. XXXVI, fig. 2).

Larvae of some species (Goes and the girdlers) feed individually, so that only one larva is found in a tree or in a certain portion of that tree. In such cases they either kill a small part of the tree or go into the dead heartwood to feed. Others, usually dead-wood feeders, when the wood is found in the proper condition for attack, breed in it in great numbers. In one species (Tetropium velutinum), the individuals are gregarious, in the sense that their existence depends on simultaneous attack. This species feeds between the bark and wood of living and weakened Larix and Tsuga, and if a sufficient number of larvae are not present to kill the tree they are unable to mature in the living wood, and die.

The cerambycids are all phytophagous, for the most part attacking arborescent plants, although a few are found in herbaceous growths. Those species feeding on living trees are more often restricted to a single species or genus of trees. Most of the species of Saperda and Goes are confined to a particular host. A peculiar case came under observation where Goes tigrina, feeding, so far as known, only on white oak (Quercus alba), laid a number of eggs in a sour gum (Nyssa sylvatica). This gum was growing in a grove of oaks and the bark very closely resembled that of the oaks. Such examples are rare. Sipecies which require freshly-cut wood have a wider variety of hosts but do not show the indiscriminate choice of purely dead-wood feeders. The conifers and deciduous or hardwood trees present barriers that are rarely crossed. Orthosoma and a few species of Leptura attack either, but it must be well decayed. Such indiscriminate feeders are those species which are most abundant numerically.

\section{ANATOMICAL CHARACTERIZATION.}

The larvae of the C'erambycidae may be said to be the most readily recognized by their form and texture. They are, in general, fleshy, cylindrical, elongate forms, having a thin body texture, which is never strongly chitinized and is covered with fine hairs or pubescence. The eoleopterous larvae most likely to be confused with them would probably be those of some genera of the Melandryidae, which resembles Leptura, or those of some genera of Erotylidae, which are IIippopsis-like. Both of these types have deeply retracted mouthparts.

This general characterization of the form includes, however, a great amount of variation. Very elongate, slender larvae are represented by llippopsis and Oberea (Pl. XXXII, fig. 4); thick, robust types almost like those of the scara-

1 The definition of both the abdominal and thoracic areas of these larvae is based on a study of the muscles by means of which the areas in different subfamilies have been homologized. This discussion was made the subject of another paper by the author (7), in which certain names were proposed for these areas, but given only as provisional. ln discussing the anatomical structure in the present paper only sucl details aregone into as will be essential for the proper understanding of the deseriptions.

Several of the terms used in the present paper may be found to differ from those applied by the author in previous papers $(1915,1916)$. In such cases the changes are based on renewed comparative morphological studies, jointly undertaken by Dr. A. G. Boving and myself on a considerable amount of adult and larval stages of different insects. This revised terminology expresses our present contentions and consequently we regard the terminology expressed in our earlier publications as cancelled and not to be drawn into further discussion. For explanation of most of the subsequent terms, see: (1) John B. Smith: Explanation of Terms used in Fintomology (published by Brooklyn Entomological Society, Brooklyn, N.Y., 1996); (2) A. D. Hopkins: The Genus Dendroctonus. (U.S. Dept. Agr., Bur. Fnt., Tech. Ser., No. 17, Pt. 1, 1909); (3) Kemner, A.: Beitrage zur Kenntnis einiger Schwedischen Koleopterenlarven. (Arch. f. Zool., Vol. 7, pp. $2-4,1912$ ); (4) F. C. Craighead: Larvae of the Prioninae. (U.S. Dept. Agriculture, Off. Sec. Rept. No. 107, 1915); (5) The Bibliography in G. C. Crampton's publication: The Thoracic sclerites of lmmature Pterygotan lnsects, with Notes on the

Relationships Indicated. (Proc. Ent. Soc. Wash., Vol. 20, No. 3, p. 60; 1918.) 
Damblate are ropresenterl hy Monilema (Pl. XXIX, fig. 5) and Tetraopes (Pl. X.XII, fje. 1); then there are purely depressed types, as Rhagium; larvae that are eompresserl, cepecially posteriorly, as Eburia (Pl. XXVII, fig. 3) and Ecyrus, ancl, again, those that are quadrate in eross-section, as Atimia (Pl. XXV, fig. 4), Iletruchthes and /letomis. The form is most constant in the Prioninae and most diversifecl in the Iamiinae.

The texture and body lairs, likewise, show a great many modifications. A hoary, tough texture, remarkably glabrous, characterizes the Prioninae, as also certain genera in all subfamilies; the opposite extreme, a very lelicate, thin, shining skin, beset with fine silky hairs, is found in such genera as Obrium and Encyclops. The skin may be dull and finely granulate, as in Tillomorpha and I'ofonocherus; or rugulose, as in Tetraopes. Again, the skin may be very densely hairy, as in Tetraopes, or it may bear coarse, stiff, almost sctose hairs, as in inthophilax, or a mixture of coarse hairs and short fine pubescence, as in saperda. special differenees of texture found on the ampullae and the pronotum will be discussed in the following pages, where the modifications of these structures are treated.

The body is rlivided into the head, three thoracic segments, and nine abdominal segments; a tenth abdominal segment is probably represented by the anal lobes.

\section{HEAD}

Two fundamental types of head are found, one in which the sides are rounded and diverge posteriorly, and the other (Lamiinae only, text fig. 1, $i$ and $j$ ) in which the sides are parallel or converge posteriorly. No intergradations betwern these types have been found, and the latter may be said to possess the only character not common to more than one subfamily. The head is usually depressed, but becomes thicker or occasionally even circular in eross-section, as in Hippopsis. Usually it is deeply embedrled in the prothorax, but sometimes is salient in the Lepturinae and few Lamiine genera. It is attached to the prothorax by a continuous band, the collar (co.), which is an extension of the prothoracic skin attached around the opening of the occipital foramen (occ. for.). This collar allows the extension and contraction of the head, procluecl by the superior $(a \mathrm{srm})$ and inferior $(\mathrm{vrm})$ retractor museles. When the hearl is deeply invaginated the collar is broad; when the head is salient, short. The exposed portion of the head is more or less heavily and darkly chitinized, the extreme being represented by the Prioninae. Dorsally the head-capsule is composed of two epicranial halves (epic) and the triangular, well-derined or olscure front $(F$.$) . The manner in which the halves of the epieranium meet$ or fuse behind the front offers good subfamily characters. In the Cerambycinae, Prioninae, and Aseminae the margins of the epieranial halves fuse for a short distance behind the front and then diverge; in the Lepturinae and Disteniinae they are entirely angulate from the posterior limit of the front, while in the Lamiinae they are fused for their entire dorsal length and are posteriorly jointly rounded. ientrally, these epieranial halves are bridged anteriorly by the hypostoma $(h y)$ with the gula $(g u)$ and posteriorly by the tentorial structures. Posteriorly and rentrally lies the large occipital foramen; it becomes ahmost directly posterior in some lamiines, and even posterior-dorsal in Distenia (Pl. NI, fig. 7). The anterior chitinized portion of the head is called the mouth frame (Pl. X); it supports the ventral mouth-parts, the mandibles, and the clypeus with labrum.

Giula, Iypostoma, and Tentorium: The gula, hypostoma, and tentorium are so fused with one another that they are best discussed together. The hypostoma $(h y)$ is that portion of the mouth-frame between the ventral mandibular articulations. In most coleopterous larvae it consists of two trapezoidal plates separated by the gula, but in all cerambycids (except Distenia) these two plates have fused medially with the gula, forming a broad anterior con- 

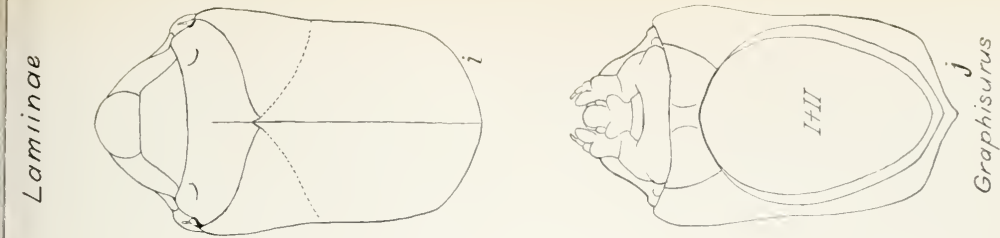

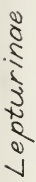
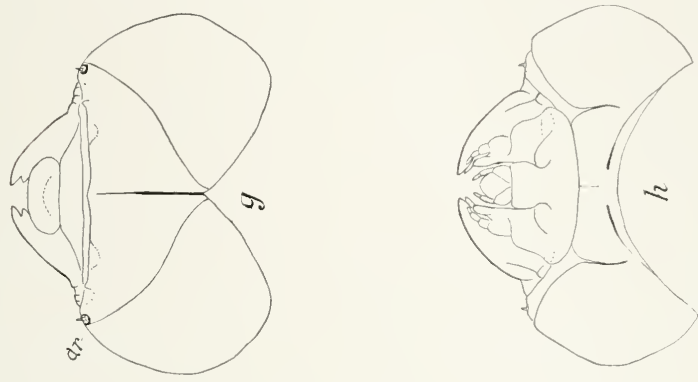

20

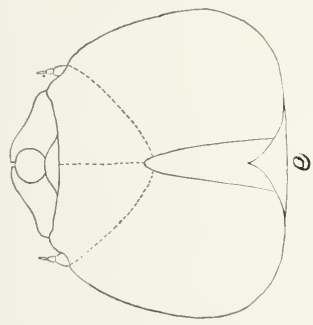

5
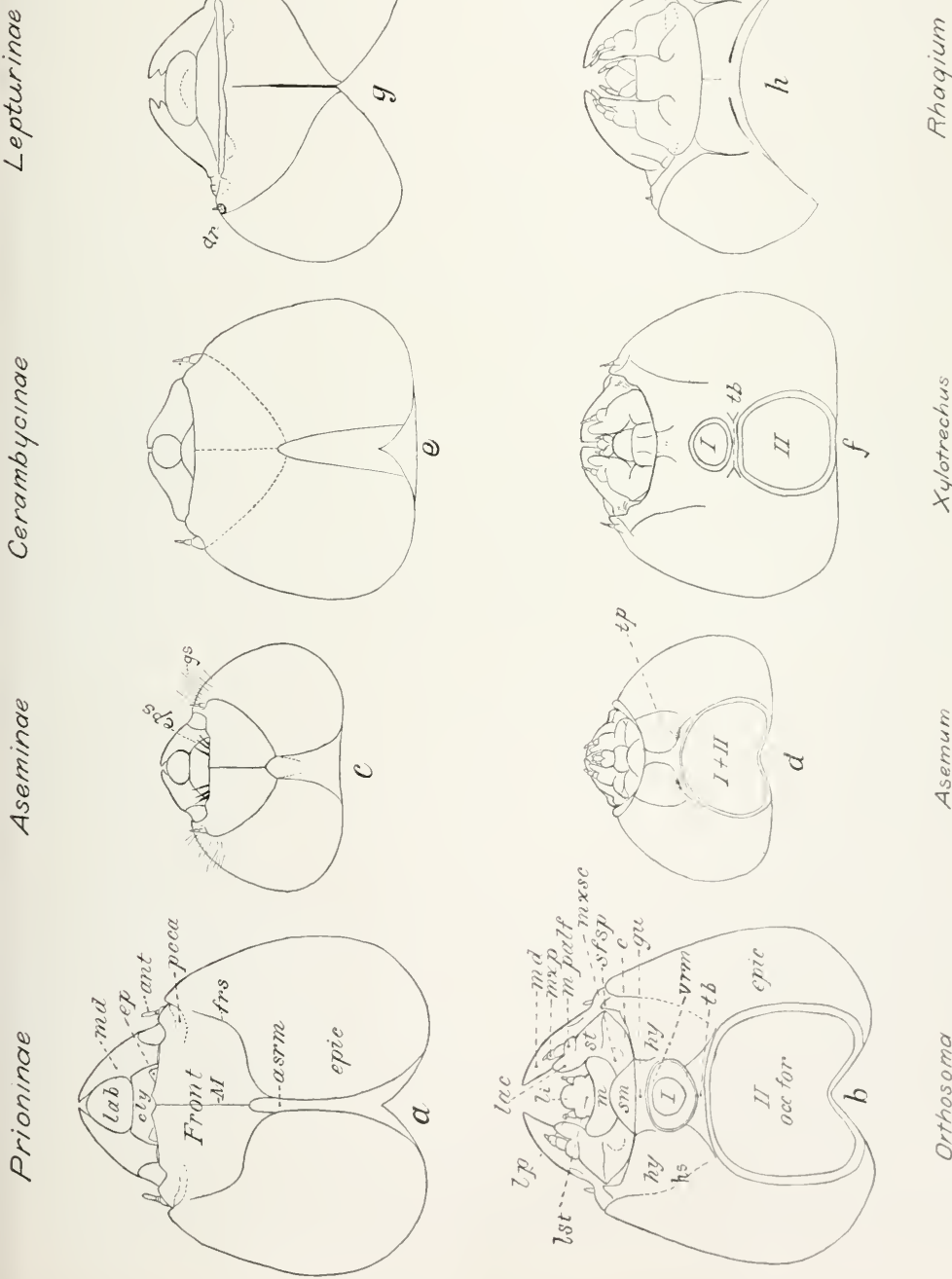

苫

2

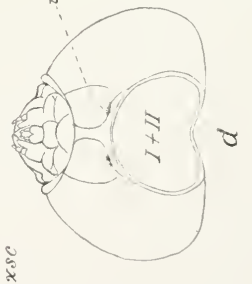

रत्तेके है

वरूे iे i
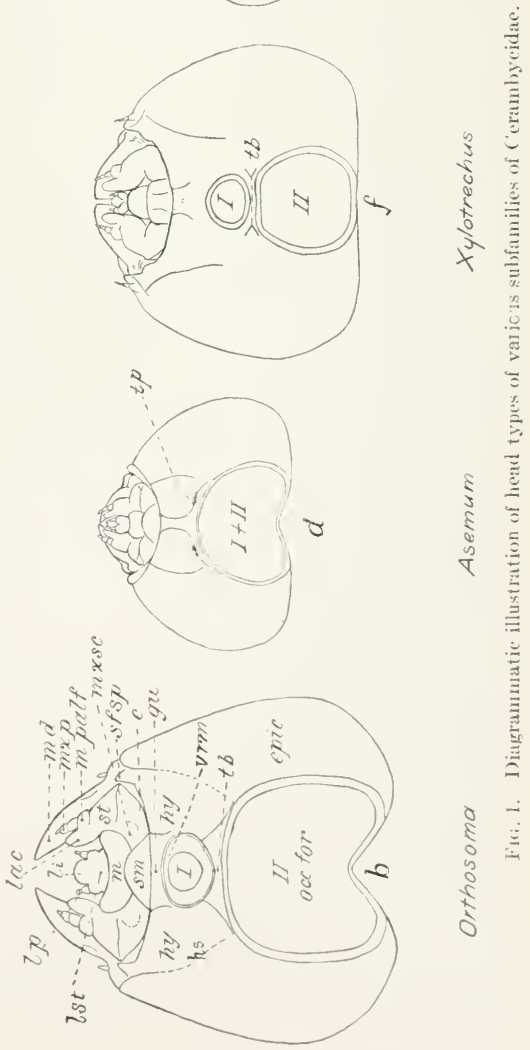
nertion just hehind the ventral mouth-parts. The anterior or maxillary margin of hipestem: is that portion hetween the ventral mandibular artieulation and the intersertion of hypostonal and gula, which intersection also corresponds, in most forms, to the articulation of the tip of the cardo. The gula (gu) lies betwern the ligpostomal plates just behind the submentum. It can be well seen in $1 \mathrm{semm}$, where the gula has the typical shape. Here it is wide, the protuluerant sutures; in other forms it is obsolete or represented only by a faint gular line. The tentorium is indieated externally by two pits or invaginations at the posterior inner angle of the hypostomal plates [see Asemum (Pl. III, fig. 8), Rhagium (Pl. XI, fig. 3)] from which extends dorsal to the frontal sutures, two ligamentous arms $(t a)$. In the Isemiinae, Lapturinae, and Iamiinae, these arms have a short cross-connection immediately inside the head. The modific:ation of such tentorial structures can be traced through Opsimus to the Cerambycinae where the pits sensibly widen, that part of the ligamentous arm between the pit and the cross-connection shortens, and the cross-connection comes to he in the same plane as the hypostoma, forming another bridge across the ventral surface of the head. This is also the structure in the Prioninae $(t b)$. This hole in front of the tentorial cross-arm is schiodte's (31) "fovea" in which, according to his description, the inferior retractor muscles of the head are attached, or, more precisely expressed, some of these muscles are attached to the tentorium near the pits. In Distenia (Pl. XI fig. 7 ) the tentorial eross-arm has broadened out and pushed forward until it forms the entire ventral connection of the epicranial halves; the hypostomal plates have not fused across the head (except with the tentorial cross-arm), and the tentorial pits on hypostoma occur in this genus at the anterior margin of the rentral bridge of the head. Distenia is also peculiar in that, apparently, no gula is present, the submentum articulating $(s a)$ directly by the collar to the prothorax. The writer believes, however, that this portion of the collar in reakity is the gula, or rather that it has been termed the gula when it has become chitinized and is attached to the surface of the fused hypostomal plates or lies between these plates when they are separated.

Labrum: The labrum (lab) is distinct and movable, varying in shape from transverse to elongate, roundly rectangular to orbicular, semicircular, fungiform, or cordate. The degree of chitinization varies. Usually only the anterior half is beset with coarse or fine, long or slender hairs; again, only the margin is ciliate.

Clypeus: The clypeus $(c l y)$ is always present just behind the labrum and is constant in shape within the subfamilies. It is either trapezoidal, widest behind, and attached to the epistoma between the entire width of the dorsal articulations of the mandibles, as in the Prioninae, Aseminae, Lepturinae, Disteniinae, and Lamiinae; or it is never as wide as the epistoma except by a hidden membraneous connection, characteristic of the Cerambycinae (text fig. $1, e, f)$. The clypeus never bear's any setae or hairs.

Front: The front (frons) or anterior dorsal plate of the head is triangular. It is laterally limited by the frontal sutures ( frs) which are either elistinct, well defined, as in the Lepturinae, or indistinct, as in most Cerambycinae,and Prioninae and in some Lamiinae. These sutures extend forward to the antennal ring (ar) which they either bisect and open behind, as in the Lepturinae, Aseminae, and some Lamiinae, or do not bisect. The median suture $(M)$ is well-defined in the Lepturinae, Aseminae, Distenia, and some Cerambycinae. A transverse suture occurs in a few genera, as in Anthophilax (Pl. XI, fig. 8). On the front just behind the dorsal articulations of the mandibles in the Prioninae is a curved arina, called the postcondylar carina (pcca).

Epistoma: The epistoma $(e p)$ is considered the anterior region or margin of the front; an infolding or thickening between the dorsal mandibular articulations. It has been seen in the Prioninae, where it forms the lower projecting 
series of dentations beneath the tuberculate or carinate edge of the front. It is straight or deeply emarginate and bears several hairs on each side, the epistomal setae (eps); in the Cerambycinae two epistomal setae are constant on each side, in the Lamiinae and Prioninae usually three, in other subfamilies three to many.

Mandible: Three distinct types of mandibles $(m d)$ are found. In the Prioninae [(Pls. XII and I), Aseminae (Pl. II), and Lepturinae (Pl. 1 and IV)] it is short and more or less triangular; the ventral apex is produced and acute; the cutting edge is very oblique, emarginate, or straight; a true molar part is never developed, but the dorsal angle of the cutting edge is either toothed, as in many Lepturinae, or flattened into a plate (Orthosoma) and this plate is often striated, as in Parandra, Ergates, the Aseminae, and some species of Leptura. In some Lepturinae the mandible is more elongate, with a short cutting edge, as in Gaurotes and Rhagium. Another mandibular type occurs in the Cerambycinae (Pl. I); it is short, robust, and especially characterized by the cutting edge rounded and gouge-like. A third form occurs in the Lamiinae (Pls. V and II); it is a more slender mandible, narrowing toward the apex, which is produced to some extent; the cutting edge is oblique; the dorsal angle is sometimes produced into a tooth, as in Dectes (Pl. V, fig. 7) and Hippopsis. The mandible of the Cerambycinae is often divided by a difference in structure into a basal and apical half (Pls. II and I). The apical half often bears a shallow impression or fovea. The mandible has two to many setae on the outer face, and this face also presents a great variation of texture and sculpture, as smooth, shining, dull, granulate, or rugulose.

Pleurostoma and Gena: The lateral region of the epicranium and mouthframe (Pl. X) between the dorsal articulations of the mandible is considered the pleurostoma $(p l)$. It may be smooth or rugulose and on its ventral portion just behind the ventral articulation of the mandible is often found a conical process or tubercle, called the subfossal process $(s f . s p$.). The gena $(g)$ is the region of the epicranium just behind the pleurostoma. It is variously modified and may be abruptly shouldered or gradually receding. ${ }^{1}$

It is more or less hairy and in some forms, as Asemum (Pl. VIII, fig. 8) beset with dense recurved hairs, called genal setae or bristles (gs); in others, as Elaphidion subpubescens, ete., with a few long hairs (Pl. X, fig. 3), and in Callichroma (Pl. IX, figs. 5 and 8) with very fine pubescence.

Ocelli: The ocelli $(o)$ are situated on the anterior part of the gena. They occur in the great majority of larvae and vary from one to five in number. They may be indistinct beneath the chitin, as in some species of Callidium; abruptly projecting; contiguous with the antennae, as in Merium, or separated from the antennae, and are often more or less surrounded by a fold of the gena. The ocelli are usually of generic value but only occasionally of specific value.

Antennae: The antennae (ant) are three-jointed and have a large basal membrane $(\mathrm{am})$ into which the other joints are more or less retractile. On the second joint beneath the third oceurs a minute "supplementary joint" (sj), to which Perris (25) attached much importance as a systematic character in the Coleoptera. In the Cerambycinae and Prioninae the antennate are salient, but in the other subfamilies they are entirely retractile into the antennal ring (ar). For this reason in certain larvae the relative lengths of the joints cannot be used to any extent in descriptions.

Tentral mouthparts: "Ventral mouthparts" is a collective name proposed to designate the following structures on the ventral surface of the head, namely, submentum, mentum, labium proper, and maxillae. The variation in these structures occurs, first, in mobility of the parts; in all except the Lamiinae the cardo

1 This distinction is used in the keys and descriptions and may be found difficult to determine. When the gena is shouldered the ocellus is usually turned so that it faces squarely forward, while when the gena is receding the ocellus faces obliquely to the side.

$57951-2$ 
and maxillary sclerito (or maxillary articulating area) are distinct and movable, but in that subfamily (l's. X, XII, XIII) they are indistinct, fused in a continuous area and only the stipes is movable. In the second place, the mode of attachnent to the head varies; in the lamiine form the ventral mouthparts are attached hy the fused base to the whole ventral surface of the head between the mandibular articulation, while in the Cerambycinae (Pl. XI) and Asemiinae (Pl. VIII, figs, 5, 6, 7,8 ) the cardo articulates near the edge of the gula on the hrpostoma. In Distenia (Pl. XI, fig. 7) the submentum is connected directly with the collar skin of the prothorax. A third variation oecurs in the arrangenent of palpifer and stipes. In the Cerambycinae (Pls. VIII and IX), Prioninae and Disteniinae, the palpifer ${ }^{1}$ is small and joint-like and the lacinia apparently is horne on the stipes, but in the other subfanilies the palpifer is large, bearing both the palpus and the lacinia.

The mentum $(m)$ is either separated by a transverse suture from the submentum (sm) or fused with it. The labium proper is attached to the mentum and is compesed of a median tongue or ligula (li), the two fused labial stipes, each of which bears a two-jointed palpus $(l p)$. Each maxilla consists of a basal articulating piece, or cardo $(c)$, the maxillary sclerite or articulating lobe (mxsc) attaching the cardo to the submentum, the stipes $(s t)$, and the palpifer $(p)$, which bears the lacinia (lac) on the inside and the palpus on the outer side. The lacinia is usually slender and cylindrical, but occasionally fleshy (Necydalis, Pl. XI, fig. 2); lanceolate (Opsimus, Pl. VIII, fig. 6), or flattened and broader toward the apex (Cerambycinae). The maxillary palpi normally are threejointed, but in Opsimus, Pogonocherus, Lepturges, some species, Tetraopes (Pl. XII, fig. 2), and Cyrtimus (Pl. XII, fig. 9), thry are two-jointed. On the outer face of the palpifer in the Cerambycinae a small fleshy process of ten is found; this the writer proposes to call the process of the palpifer $(p p)$. A similar process is sometimes present on the basal joint of the maxillary palpus. It is well developed in Methia (Pl. VIII, fig. 4).

\section{THE BODY SEGMENTS}

The fleshy body of the cerambycid larva is capable of considerable contraction and expansion which enables it to move in its close-fitting burrows,

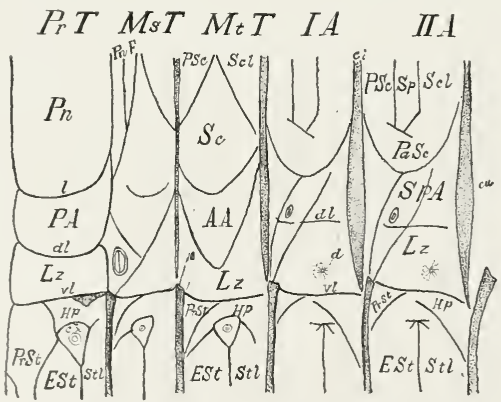

FIG. 2. Diagrammatic illustration of selerites and lines of a larva of the Frioninae. For explanation of abbreviations, see page 150 .

the legs being of little or no use. This shortening and contracting of the segments is produced by the muscles; the expansion and lengthening of the sagments and the swelling of the ampullae is caused by a relaxation of the muscles

1 Later studies in colenpterous larvae have suggested that this difference is more apparent than real, and only a difference in the deerpe of fusic $n$ ? the palpifer and the stipes. Also the lobe termed lacinia may be more correctly spoken of vith the indefinite expression mala. 
and an accompanying increase (in those segments) of the body fluids. A considerable amount of this longitudinal expansion is permitted by a peculiar arrangement of the intersegmental skin (as described by Boving, 2). This intersegmental skin consists principally of a dorsal and a ventral wedge-shaped perpendicular band, the dorsal and ventral cunei $(c u)$, the extremities of which overlap along the sides.

The length of the body is largely dependent on the width of these cunei and the manner in which they are placed. In short, robust forms of larvae they are very narrow and set almost directly in the same vertical plane, i.e., one directly above the other, in which case very little contraction is permissible. In very elongate and slender larvae, as Distenia, Elaphidion subpubescens, or Oberea, and usually in forms that can move rapidly in their mines, the cune: themselves are very wide and the ventral situated some distance behind the dorsal, and not only the cunei themselves are capable of contraction but also the intervening intersegmental skin.

Approaching the thoracic segments the cunei always shorten and between these segments they are in the same plane, one situated directly above the other, so that little or no expansion is permitted.

A well-defined protuberant fold or region, the lateral zone $(L z)$ or epipleurum as it is here termed, is developed along the entire side of the body (compare Leptura larvae), though less conspicuous on the thoracie segments. It readily separates the dorsal and ventral regions of the segments. This epipleurum represents only a portion of the adult pleurum.

\section{THORAX}

The dorsal region of the thorax above the epipleurum is divided into the following areas: prescutum, scutum, scutellum, and alar area. The term notum $(N)$ is used to indicate the complete plate formed by the fusion of the prescutum, scutum, and scutellum. The term tergum $(T)$ is used to designate the entire dorsal region above the epipleurum.

The region of the thorax below the epipleurum is divided into presternum, eusternum, sternellum, coxa, and hypopleurum. When these areas are fused and indistinct the whole region is collectively termed sternum $(S)$.

The prothoracic segment $(\operatorname{Pr} T)$ is always much larger than the other

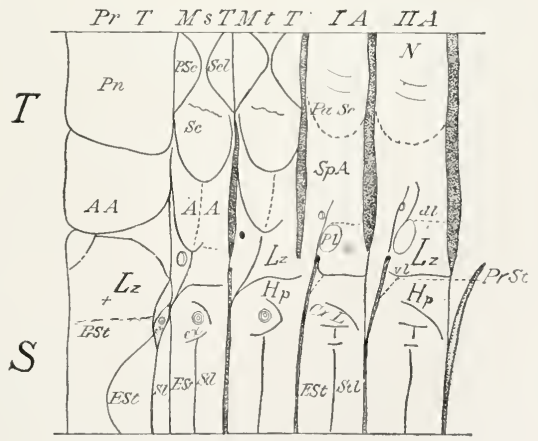

FIG. 3. Diagrammatic illustration of sclerites and lines of a larva of the Aseminae, For explanation of abbreviations, see page 150 .

thoracic segments, usually about the size of the other two combined, and is more subject to modification. The mesothorax $\left(M_{s} T\right)$ and metathorax $(M t T)$ are of about equal size or the latter is somewhat larger. 
The diseussion of these segments an be most conveniently followed by taking as the type the mesothorax of the Lepturinae, in which the areas are more distinct, and contrasting it with the modifications in the thoracic segments of other sulufamilios.

Ejpiplezum: 'The epiplenrum $(L z)$ of the mesothorax is shaped somewhat like an homl-glass, narrow in the midcle with anterior and posterior extremities extencled. The dorsal and ventral curved sutmes limiting this zone will be termol the dorso-lateral $(d l)$ and ventro-lateral $(v l)$ sutures. It is often divided hy an oblique sinture extending forward ventrally into an anterior triangle, the pre-cpipleurum, which bears the mesothoracic spiracte. In the Cerambycinae and in the metathoracic segment of the Lamiinae the anterior ventral angle extends much farther downward than usual below the upper end of the ventral cunens, the projection includes the presternum $(\operatorname{Pr} S t)$, which is not defined dorsally by the uswal suture.

The cpipleurum in the prothorax is erescent-shaped in the Lepturinae (fig. 5); rectangular in the Prioninae (fig. 2), the Lamiinae (fig. 8) and some of the Cerambycinae (fig. 4), and entirely or only anteriorly fused with the ventral eloments in some Cerambycinae and in the Disteniinae (fig. 6).

Alar area: Above the V-shaped dorso-lateral suture hies the alar area $(A A)$. It is characteristically wedge-shaped, with the apex below; in the Lamiinae and some Prioninae almost bisecting the epipleurum. Dorsally the alar area is limited by a more or less concave longitudinal sutura which mats tha cuneus posteriorly at the same muscle notch as does the lower end of the scutellum.

In the prothorax the alar area $(P A)$ is trapezoickal to rectangular and may or may not be completely set off from the area above (the pronotum, $P n$ ) by a suture. It is usually more or less chitinized and clothed in varying degrees of hairiness. When designated in descriptions it is spoken of as the pro-aiar area.

Notum, Prescutum, Scutum, and Scutellum: The remaining dorsal areas are either entircly fused (in many Lamiinae) and spoken of as the notum $(N)$, or separated by $\mathrm{x}$-shaped sutures into a triangular prescutum $(P S c)$, a triangular

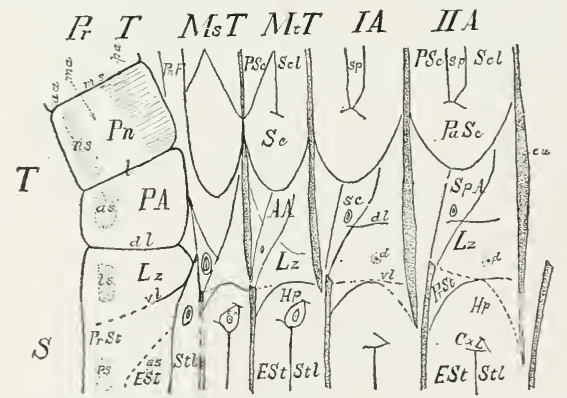

FIG.4. Diagrammatic illustration of sclerites and lines of a larva of the Cerambycinae. For explanation of abbreviations, see page 150 .

scutellum behind $(S c l)$, and katerally a diamond-shaped or triangular scutum $(S c)$, atl of whose apices meet in the longitudinal median-dorsal line. In the metathorax of some Cerambycinae and Lamiinae a single transverse suture marks off an anterior transverse prescutum and a posterior transverse scutellum, the region below being the scutum. The extremities of these areas, however, are then not definitely defined. In both the mesothorax and metathorax of the Lepturinae and in the metathorax of the Prioninae and the Lamiinae a small triangle is marked off, which possibly is part of the alar area, but is here consickered as a lower portion of the scutum. 
Pronotum: These notal areas have fused in the prothorax into a large rectangular plate, the pronotum $(P n)$. When not fused with the alar area, it is limited below by a lateral suture or impression, the lateral suture $(l)$ of pronotum which may extend along the entire prothorax or only for a short distance. Sometimes the pronotum is also divided by a longitudinal median suture ( $m$ ) of pronotum, which may or may not be impressed for the entire width of the pronotum. The pronotum is variously modified by differences in sculpture and texture to a greater extent than any other borly region. Usually it is defirable into an anterior area (aa), more or less chitinized, smooth and shining; a median punctured area $(m a)$, and a posterior area $(p a)$. This posterior area shows the greatest variation; it may be smooth and shining or finely or coarsely granulated and either opaque or shining; reticulate; finely, coarsely or pinnately striate; protuberant in various shapes; or finely vellured to coarsely asperate. This variation offers one of the most valuable specific characters.

Postnotal fold: In the Prioninae and nearly all the Cerambycinae a transverse fold, the postnotal fold $(P n f)$, is found just behind the fused notal areas of the prothorax. It is considered a development of the intersegmental skin.

Presternum: The presternum $(\operatorname{Pr} S t)$ is represented by a triangular area lying in front of the segment, against the ventral cuneus and just below the epipleurum. Occasionally it extends ventrally until the apices meet medially. This is usually the case in the prothorax, where it becomes quite large, and in sone of the Cerambycinae, in the Aseminae, and in the Disteniinac it is fused with the epipleurum into a broad ventral region.

Eusternum and Sternellum: A transverse line across the segment between the coxae sets off an anterior transverse eusternum (Est) and a posterior transverse sternellum $(S t l)$. In the prothorax the eusternum is often not defined, but when so it usually has a roundly triangular form and is variously sculptured. The sternellum in the prothorax forms in the Cerambycinae a very distinct

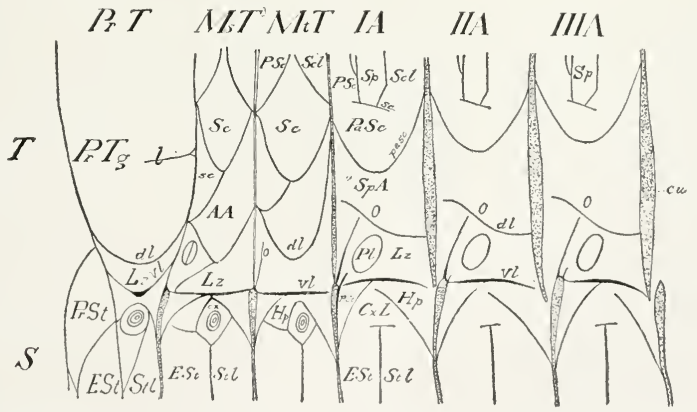

Fig. 5. Diagrammatic illustration of sclerites and lines of a larva of the Lepturinae. For explanation of abbreviations, see page 150 .

fold by the fusion with a portion of the hypopleurum, and its extremities often extend to or beyond the spiracles. In such cases it is spoken of as the sternellar fold and bears the legs. In other forms this sternellar fold is not distinct at its extremities but fused with the epipleurum.

Hypopleurum: The hypopleurum $\left(H_{p}\right)$ lies beneath the epipleurum, behind the presternum and contiguous with the basal portion of the leg. In many coleopterous larvae it is chitinized and divided into an anterior prehypopleurum and a posterior part (posthypopleurum), but in none of the cerambycid larvae does any chitinization occur, nor is it ever entirely divided in these forms, the nearest approach to this condition is found in the Lepturinae. 
Coxa and leg: lecgs are in general poorly developed in the cerambycid lalrace. In one sulfamily, the Lamiinae, they rarely oceur. They are also alsent in some of the Cerambycinae, or only developed as a minute spine, but in other ('ormbycinae they are two-, three-, four- or five-jointed. In the remaining families they always are present, best developed in the lepturinae. The fleshy lobe or joint forming the base of the leg is the coxa $(c x)$, which is surromuded, above by the hypopleurum and bencath by the eusternum and sternellum. In the prothorax of the Prioninae and Lepturinae the coxas meet or almost meet, medially. The last joint, the claw-like tarsus $(t)$, is most extensively molified and may be a short conical or a long spine; in the Lepturinae a long seta often exterids from near the base on the inner face. The other joints are, named from the base outward, trochanter, femur, and tibia (Pl. XXII). When the leg is represented only by a short spine it is assumed that these middle joints are lost.

The prothoracic, tergal, lateral, sternal, and eusternal plates or spots: The anterior margin of the prothorax in many cerambycid larvae tends to become more or less chitinized. This chitinization is stronger at certain points in rectangular or oval plates or spots. Four tergal plates occur, of which two are

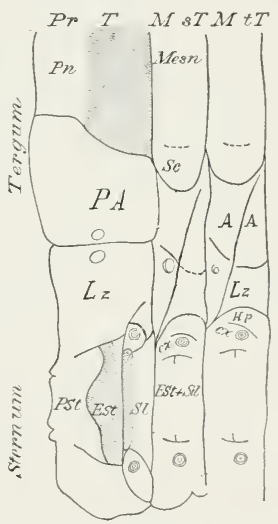

FIG. 6. Diagrammatic illustration of selerites and lines of thorax of a larva of the Disteniinae. For explanation of abbreviatiors, see page 150 .

pronctal ( $n s$ ) and two, one on each side proalar (as); two lateral spots (ls), one on each side, occur on the epipleurum and two are presternal (ps). The eusternum also often bears two similar spots of chitinization (es). These plates or spots are more distinct on living larvae and usually are some shade of yellow. They afford good descriptive characters.

\section{THE ABDOMEN}

As before stated, the epipleurum separates the abdominal segments into a dorsal and ventral region. These regions above and below the epipleurum are divided into certain areas, some of which ean be homologized with thoracic areas and are similarly named. Others are special abdominal developments or are questionably homologizable with the thoracic areas. In either case a new name has been applied. The abdominal areas above and below the epipleurum are as follows: 
Above the epipleurum the region is divided into prescutum, the scutal plate, the scutellum, the parascutum (ParSc), and the spiracular area (Spa) or alar area.

Below the epipleurum the region is divided into presternum, eusternum, sternellum, hypopleurum, and the coxal lobe $(\mathrm{C} x \mathrm{l})$.

Epipleurum: The epipleurum is often the most conspicuous abdominal area. It is strongly protuberant on all segments in most Lepturinae and many Lamiinae. In other Lamiinae it is only protuberant on five to seven segments, while in still others and in all the Cerambycinae, Prioninae, Aseminae and Distenimae it is protuberant only on the last three abdominal segments. Typically the region is somewhat oblique, the anterior extremity being slightly higher than the posterior. In the Cerambycinae and the Aseminae the sutures defining the epipleurum above are often indistinct on those segments on which it is not protuberant.

Pleural tubercule and disc: On the epipleurum in many larvae is a more or less conspicuous lobe or tubercule, the pleural tubercle $(\mathrm{Pl})$. It is usually better developed on those segments on which the epipleurum is protuberant. The shape of this tubercle and the number of hairs or setae it bears offer very good specific characters.

In the Prioninae and Cerambycinae a disc of contrasting texture is found on the epipleurum in those segments where it is not protuberant. This disc, the pleural disc $(d)$, is most conspicuous on the first three abdominal segments, becoming less so posteriorly. It may be present on from three to six segments. Near its centre is a small pore or pit surrounded by radial or sinuous striations or by a dull, finely granulate to rugulose integument. Again, it is somewhat obliterated by the pleural tubercle in some Cerambycinae. In the Lamimae a homologous structure occurs on the pleural tubercle. At each extremity of this tubercle in many genera can be found a chitinous pore or pit $(c p)$ ). The anatomy of these structures has been deseribed by Hess (13) and associated with chordotonal organs.

Ampullae: Probably the most conspicuous abdominal structures of many cerambycid larvae are the dorsal and the ventral protuberanees of the first six or seven segments. These protuberances are used by the larvae in moving in their burrows and have been named the ambulatory ampullae (Amb Amp) by

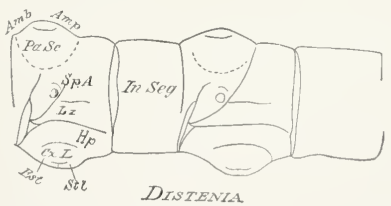

Fig. 7. Diagrammatic illustration of selerites and lines of abdomen of a larva of the Disteniinae. For explanation of abbreviations, sce page 150 .

Perris (23). These ampullae are formed from a dorsal protuberance of the prescutum, scutal plate, parascutum, and scutellum, and from a ventral protuberance of the eusternum and sternellum.

It would be expected that developments of such constant use to the lirvie would be greatly modified to conform to various conditions of life habits. This is eertainly the ease, and the wide variation in their shape and armature is of special systematic value, furnishing specific, generic and subfamily characters.

The ampullae (Pls. XXIX, XXX, XXXI, XXXII) may be projecting and with a flat surface, as in Cyllene, having one to several transverse impressions and often a small longitudinal furrow. The transverse impressions may be parallel or converging toward a lateral impression so as to form a hexigonal, 
elliptical, or diamond-shaped area. In other forms, as Atimia, Callimoxys, Encyclops, and Hetoemis, they are more prominently projecting and the longitudinal furrow is deepened until the ampullae appear completely divided into two separate lobes. The surface texture of these ampullae is always in contrast to that of the other portions of the boty; it may be granulate, with the granules dull or shining, fine, coarse, or eren placoid; or tuberculate, with small or large, distinct or confluent tubercules arranged in two, three, or four regular or irregular rows: or it may le striate. The tubercules or even the flat surface may be fincly pubeseent or velured to strongly asperate. In the Prioninae seven ampullae are developed, large projecting lobes with a flat surface usually more or less rugulose: dorsally they bear two transverse impressions, ventrally one: within this group is found the least variation. In the Aseminae they are usually fincly velured, in the Cerambycinac granulate in various degrees, in the Lepturinae and I.amiinae tubereulate or some variation therefrom.

Prescutum, Scutellum, and Scutal plate: In most larvae the dorsal ampullae have two transverse impressions that meet a lateral one on each side. For the inclosed region the writer proposes the name "scutal plate" (sp) (scutum of Craighead, 1915). In many Aseminae and Lamiinae another lateral impression

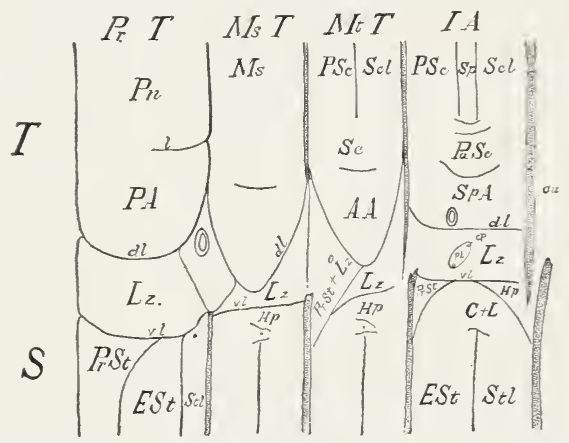

Fig. 8.-Diagrammatic illustration of sclerites and lines of a larva of the Lamiinae. For explanation of abbreviations, see page 150 .

is often found, produced by a division of the large muscle that contracts the ampullae. In front of the scutal plate is a poorly-defined region, and behind the latter a similar one, respectively interpreted as the prescutum and scutellum These regions correspond more or less to those of the thorax.

Parascutum: Directly below the scutal plate is a large region, the parascutum $(P a S c)$. Tentrally it is defined by a curved line that coincides more or less with the basal limit of the ampullar protuberance. Often this line is indistinct, but then there usually ean be found a muscle sear just above and behind the spiracle representing its position. Between this muscle mark and the scutal plate is a row of similar marks produced by longitudinal muscles characteristic of this area. Dorsally the anterior and posterior dorsal limits of the parascutum are not distinct from the prescutum and seutellum. This parascutum is supposed to be homologous with the whole thoracic scutum and in reality includes the scutal plate, but is so definitely separated by the transverse suture (when ampullae are developed) that different names are deemed appropriate.

Spiracular area or Alar area: Between the parascutum and the epipleurum lies a large area bearing the spiracle, the spiracular area (SpA) (Boving, 2). Its apices extend dorsad both anteriorly and posteriorly following the curved 
parascutum. The ventral limit is well-defined when the epipleurum is protuberant: otherwise it has to be located by a faint line marking the dorsal margin of the epipleurum or by a few muscle marks just below the spiracle.

In the Prioninae, Aseminae, Cerambycinae, and Disteniinae the spiracular area bears a protuding elliptical region in the centre of which the spiracle is situated. It also apparently takes in part of the epipleurum extending from the notch on the ventral cuneus. When spoken of it will be called the spiracular ellipse (se), but it is not regarded as a definite area. It is formed by certain muscle attachments and becomes more pronounced in those forms in which the epipleurum is less protuberant.

Hypopleurum and Coxal Lobe: Just beneath the epipleurum is a broad trarsverse region extending down to a short transverse suture on each side of the ampullae. This region consists of two distinct areas, the hypopleurum (II p) and the coxal lobe $(C x L)$. The hypopleurum is above and separated by an oblique line from the coxal lobe. In the Cerambycinae and Aseminae the hypopleurum is nearly trarsverse (to the segment) and very large; the coxal lobe is quite small. In the other subfamilies the hypopleurum is pushed backward by the enlarging of the coxal lobe until it forms a triangular area limited below by an oblique line extending from near the middle of the epipleurum. In some larvae the ventral ampullae are flat and the hypopleurum and coxal lobe strongly protrude laterally. Curius (Pl. XXVII, fig. 4) shows this development very well.

Presternum: Anteriorly, just below the epipleurum is found a small triangular area, the presternum $(P r S t)$. In the Cerambycinae and Lamiinae it is often not definitely separated from the epipleurum but superficially appears as though it were r.erely an anterior ventral protrusion of this region.

Eusternum and Sternellum: The ventrally protruding region of the segment forming the ampullae has, in most larvae, a transverse impression usually meeting laterally a shorter longitudinal one. The area in front of this transverse line is the eusternum (Est), that behind, the sternellum (Stl). Neither can be definitely limited laterally but they fuse to a greater or lesser extent with the coxal lobe or hypopleurum.

\section{NINTH ABDOMINAL SEGMENT}

The ninth abdominal segment, together with the anal lobes (al), may be more or less telescoped into the preceding segment. Such is the case in the Cerambycinae and most other cerambycid larvae, but in the Prioninae it is swollen and extended. In one genus, Aneflus, this segment is heavily chitinized.

Caudal Spines and Cerei: The ninth abdominal segment often bears on the tergum one or two chitinous points of various shapes or sizes, the caudal spines or cerci $(e i)$.

Anal Lobes and Anal Spines: Contractible into the ninth abdominal segment are three lobes, the anal lobes $(a l)$, which surround the anus. (1ne is situated dorsally, the others latero-ventrally. Rarely, as in P'tychodes (Pl. VII, fig. 15), only two lobes are present, a dorsal and a ventral. Occasionally, as in Dorcasehema (Pl. VII, fig. 9), the dorsal lobe bears a spine, the anal spine (ai). 


\section{BRILI: CII IRICTERIZITION OF LARVAE OF THE FAMILY CERAMIBYCII) AE.}

The latrate of the family ('erambyeidae may be briefly characterized as In|luा

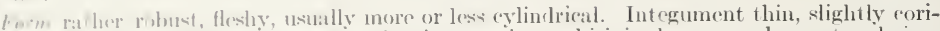

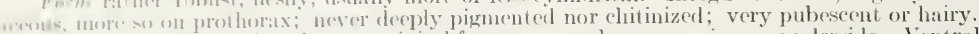

Ih ad uxmeible; ocriput large; occipital foramen very large, opening on underside. Ventral

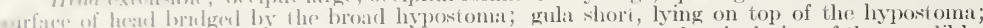

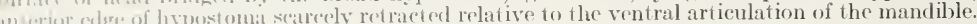
lantenl mouth-pits compact, not retracted; maxillary stipes not free (movable only in one blane: mastlary sederite distinet, often cushioned. Clypeus and labrum distinet. Mandibles short, ifuindrangulat; no molar part.

Peothure, large, membranous; collar articulating head with prothorax wide. No hypoDlenral chitizination on thorax. Legs either small or wanting, widely distant, conical, tarsus

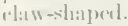

Thitomen extemled, segments readily telescoping on one another, dorsally and ventrally bearing fleshy umbulatory ampullac. Spiracles bilabiate, the two-lipped respiratory opening ntrrow; lips membramous, clothed with setigerous tubereles. Cerci absent, or chitinous unjointerl processes. Anal lobes three (rarely two), ex-erted, terminal.

\section{KIY 'T) THE STBFAMHLEN OF' CERAMBYCIDAE}

Hend transverse, wider behind the midlle. .

IIeal ohtong, sides parallel or converging behind f .

1. Vandibles with oblique cutting edge (except in Opsimus) . . . . . . . . . . . . . . 2

Vandibles with rounded, gougelike cuting elge ....

2. Dorsal margins of epicranial halves parily fused behind front . . . . . . . . . . . . 3

Dursal margins of epicranial halves separaied behind front.................... 4

3. Ejistom: projecting over clypeus; front projecting over epistoma, dentate or earinate (except in Parandra); tentorial cross-arm in same plane as hypostoma, forming a bridge behind it. Legs present t. theninae Veitluce epistomi nor front projecting; tentorial cross-arm internal. Legs present . A seminae

4. Tentorial cross-arm internal; palpifer large, bearing lacinia and palpus; epipleurum protuberaut on all aldominal segments, Legs present ...................... Lepturinae

Tentorial cross-arm in same plane as hypostoma, bridging the anterior ventral surface of the head: palpifer small, joint-like; lacinia apparently borne on stipes. Form very elongate, slender. tegs present. .

5. Epistoma never projecing; tentorial cross-arm in same plane as hypostoma and forming a britge behind it: elvpeis never filling space between dorsal articulations of mandibles; epipleurum protuberant only on last three abdominal segments. Legs present or absent. Cerambycinae

6. Fistoma never projecting; tentorial cross-arm internal; epipleurum variously protuberant. Legs usually absent

Lamiinae

\section{Subfamily PIRIONINAE}

The Prioninae constitute a group of uniformly large larvae. They are remarkably glabrous for cerambycids and of robust form. In all except Parandia the epistoma projects over the head in a more or less dentate carina, and the anterior margin of the front is variously modified into a earina, teeth, or tubereles. The ampullae are broad and flat, conspicuously marked by two transverse parallel impressions. The pleural dises are conspicuous in this group as large circular spots of a rugulose or raclially striate texture. They may be present on from three to six segments. The last abdominal segment is relatively large and more protrusive than in other cerambycids. Legs are

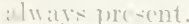

Thise larvae consitute a well-defined group with no sensible gradations into orh'r smbermilic.

\section{FOOD HABITS}

Gencrally speaking these larvae feed in wood in contact with the ground or those portions of a tree beneath the ground. They require considerable moisture and are casily affected by drying. One species, Sphenostethus taslei, 
attacks dry, dead, seasoned tops of various hardwoods. The larval mines are large, extensive burrows rather loosely packed with coarse shredded frass. They are often associated with species of Leptura and continue working in the same dead log or stump until it is completely consumed. Some species are peculiar to conifers, others only to hardwoods, and a few Orthosoma indiscriminately attack either. The genus Priomus has been found only in the roots of living trees. It burrows extensively through the ground from root to root.

The larvae require from two to four years to complete their development. From the same group of eggs laid by a single female Orthosoma some adults appeared after two years and others after three years.

\section{CHARACTERIZATION OF LARVAE OF THE SUBFAMILY PRIONINAE.} lows:

The characters of the Prioninae larvae may be briefly summarized as fol-

Head transverse, dorsal margins of epicranial halves behind front fused for some distance, later separating, angulate; tentorial cross-arm lowered in a plane parallel to the hypostoma (i.e. occipital foramen apparently divided into an anterior and posterior portion).

Mandibles wedge-shaped, cuting edge broadly emarginate, apex produced, acute.

Epistoma produced in two triangular lobes or a dentate carina over clypeus (except in Parandra); three epistomal setae on each side; front produced over epistoma, dentate or carinate. Clypeus thick, trapezoidal, as wide at base as epistoma. Labrum broad, thick, semicircular or cordate.

Maxillae moveable; cardo distince; maxillary sclerie full, cushioned; palpifor not disinet, small; lacinia borne on sipes; ventral mouih-paris attached to hyposioma by litile more than width of gula.

Antennae strong, partially reiractile.

Prothorax having presiernum and epipleurum disinct; eusternum of prothorax partially or entirely distinct; coxal lobe, large, surrounded by large hypopleurum. Mesothoracic spiracte protruding somewhat into prothorax. Legs short, stout, conical.

Epipteurum of abdomen protuberant only on last three segnents; hypopleurum distinet; coxal lobes large; spiracle in a well defined, ellipical region. Dorsal ambulatory ampullae bearing two transverse impressions; the ventral, one impression.

Vinth abdominal segment large, extended, never telescoped wihin the eighth.

\section{KEY TO THE KNOWN GENERA OF THE PRIONINAE}

Epistoma not projecting over the clypeus. Posterior area of the pronotum and the ampullae asperaie.

Epistoma projecting over clypeus; front either dencate or carinate

Neither pronotum nor ampullae asperate.

P'arandra

1. Pleural dises distinct on two to four abdominal segments . .

Pleûral dises distinct on six abdominal segments

2. Mandible having cutting edge entire.

andible with upper portion of cutting edge flackened into a siriated plate-........

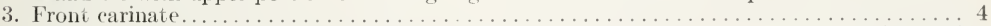

Front bearing four accuminace teeth. Three prominent ocelli.......... sphenostethus

4. Front produced in a smooth transverse carina or not at all. Inierior area of epipleurum of prothorax bearing a group of shori conical chicinous spines. Lasi joint of palpi very short,

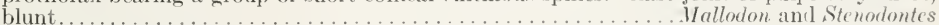

Front produced in a transverse dentate carina divided in the middle. Epipleurum of prothorax not armed... . ...........5

5. Carina of front distincily divided into four broad lobes; last jomt of maxillary palpi shorter than second; texture rugose. .................... Derobrachus

Carina not distinctly divided into four broad lobes; last joint of maxillary palpi longer than second, conical; texture smooth.

6. Front extended in four large, blunt, rounded teeth. Ocelli scarcely visible.

Front exiended into four flatiened, acule-edged, dentate tecels. Ocelli 3 to 4 , prominent... Tragosoma

7. Front projecting over epistoma in a transverse carina; never dentate; (p)istoma usually of two lobes.

Epistoma projecting in four flat, obtuse tubercules

P'rionus

II omacesthesis

NoтE.- In a previous paper the author (6) has deseribed the larvae of the following genera: Purandra, Mallodon, Stenodontes, Derobrachus, Orthosomz, Prionus, Ergates. Tragosomı, and sphenostcthus. Several other speries have been reared since and the pupae of some of the prese ding found, which are treated in this paper. They are the larvae and pupae of Ilomaestiesis and the pupae of Parandra, Ifallodon, Orthosoma, Ergates, sphenostethus, Tragosomis and Prionus. 
IIOM.MESTIHESIS leronte

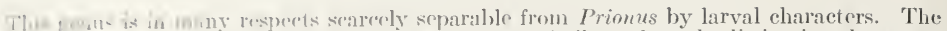

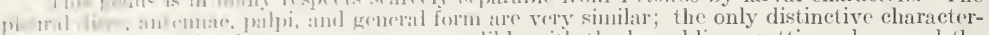

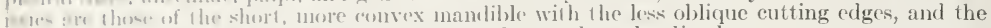
me lun thith of the epistomia, (ither as large or larger than the distal.

The 1. lam: su far as known, feed on the roots of glasses and related plants. They burrow

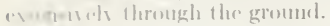

\title{
IIOM.IISTIIESIS EMARGINATUS Say
}

\author{
[1’l. I, fig. 10; Pl. XII, figs. 10, 11, 12]
}

Fimm chmlrieal, slighlly lapering posteriorly; integument very finely granulate, shining,

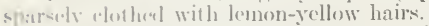

/leml subrectangular, slightly consiriciel on sides behind gena and somewhat produeed at latse behiml attarhment of dowal retractor muscles; epistoma projecting over elypeus in four prommont, flat, obtuse tubereles, the two median approximate; front searcely projecting in a dull rommlel transverse carina. Iabrum transverse, subtrapezoidal, sparsely haired; mandibles rubust, strumgly curvel on onter face (when seen from above), basal portion brownish, shining apic:al dull black, eutting edge straight, very licke obliquely inclined, dorsal angle not strongly toutlunl; antemile thec-jointed (as in Prionus), first joint shortest, transverse, second globular, bearing the minuts third. Veniral mouth-paris rather soft, fleshy, maxillary palpi conical, two basal joints transverse, last slightly larger, eylindrical, and bluntly round, about equal to last lisbial. P'ostendylar carina faint; subfossal spine acutely conieal.

I'rotherax quadrangular. Anterior area of pronotum with transverse band of short hairs, posterior rugulose. Lusternum completely separated from presternum. Legs short, hairy, tarsus a slender spine.

iblominal ampullae rather prominently projecting. Pleural dise radially striate, distinct on first six ablominal segments. Spiracles rather small, oval, peritreme slightly ehitinized.

P'up: Ls studiel from a larval skin no difference ean be seen from Prionus. It is absolutcly unarmel and pupates in an earthen cell, as does Prionus.

Egg: Elongate ovoid, 5 by $1.5 \mathrm{~mm}$., largest beyond middle opposite micropyle, from which it gradually tapers to apex; texture firm, tough, strongly or finely pitted or honeyconbed.

[Described from specimens Hopk. U S. $11860 j$.]

The larva of this species feeds on the roots of grasses, burrowing through the earth from plant to plant. It occasionally does considerable damage by killing the plots of grass. Adults were collected flying, about the middle of July and the males were attracted by lights. The eggs are laid in the earth at the base of grass stems, where they hatch in about 30 days. The larva requires three years to mature, finally pupating in an earthen cell. The foregoing interesting observations were made by Mr. W. D. Edmonston at Larkispur, Colo.

\section{IIOMAESTHESIS sp. (INTEGER LeConte?) ${ }^{1}$}

Distinguished from $H$. emarginatus only by the fact that the distal teeth or projections on the epistona are quite small and acute and some distance from the median ones, the medial largur anil obtusely rounded; the carina of the projecting front is sharper edged and distinctly arcuate, and a short carina is present in the region of the ocelli.

(1) wertibed from speeimens Hopk. U. S. 9906u.]

These specimens were sent in from Nebraska by a correspondent who stated that the larvae had destroyed a large portion of the corn (Zea mays) in a fickl by eating the roots. The specimens (three) are uniformly distinct from H. cmuminatus and are therefore described as the other species of that genus. A specimen has been scen that was collected in the tuber of a sweet potato (I pomola batutas) by F. ('. Pratt.

\section{KI: TO DESCRIBED PUPAE OF PRIONINAE}

Margin of pronotum entire; two acute caudal cerei.....................Parandra Margin of pronotum denticulate, serrate, etc.

Anterior inargin of third, fourth, fifth and sixth abdominal terga bearing two distinct carinae.

1 Described as Pr Pmesp. (6). 
No caudal cerci.

Two caudal cerci prescnt.

Margin of abdominal carinae entire

Mallodon ${ }^{1}$

Margin of abdominal carinae dentate.

Cerci obtusely conical, tuberculiform . . . . . . . . . . . . . . . . . . Ergates ${ }^{1}$

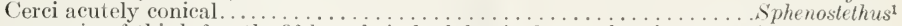

Anterior margin of third, fourth, fifth and sixth abdominal terga bearing no carinae.

Body armed with small chitinous spines; two caudal cerci................ Tragosoma

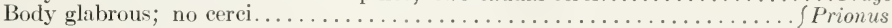

Homaesthesis

\section{PARANDRA BRUNNEA Fabricius}

\section{[Pl. XXVI, fig. 4]}

Pupa: Form similar to that of adult; head glabrous, pronotum armed with scattercd, minute conical spines on lateral borders and posterior margin; several groups of smaller ones on mesonotum and metanotum; each abdominal tergum armed with similar recurved spines, which are more numerous posteriorly; the epipleurum also, which is slightly protuberant, bearing a group; last tergum bearing two stout acuminate spines widely separated at base, extending posteriorly and laterally.

Egg: Elongate, cylindrical, $1.5 \mathrm{~mm}$. by $0.5 \mathrm{~mm}$; widest at middle, tapering slightly to both ends, which are bluntly rounded; bcaring a rather large micropyle at the larger cnd; texture smooth, no trace of sculpturing.

The larva was first described by Osten-Sacken (22).

\section{TRAGOSOMA HARRISII LeConte}

Pupa: Form similar to that of adult; head and thoracic segments glabrous; abdominal terga bearing numerous acute, conical, chitinous points, the central median ones larger, on first tergum fewer and smaller, increasing posteriorly; epipleurum of all but first three bearing a group of short conical spines; ninth tergum armed with two acutely conical, widely separated, chitinous processes. No carina present on abdominal tergum.

\section{SPIIENOSTETHUS TASLEI Buquet}

Pupa: Form similar to that of adult; head and thoracic segments bearing a few seattered, minute, chitinous points; abdominal terga bearing a transverse row of acutely triangular, flattened points, more numerous and strongly chitinized on posterior segments; carina on abdominal terga finely crenulate or lentate; epipleurum beset with several points similar to tergal; ninth tergum with two diverging, acutely conical, chitinous processes or cerei.

\section{PRIONUS IMBRICORNIS Linnaeus}

Pupa: Form as of adult; body entirely glabrous, devoid of any chitinous spines or points; abdominal terga very fincly wrinkled and epipleurum strongly so; ninth abdominal tergum bearing two small, globular, fleshy protuberances.

The pupae of this genus are remarkable in that they are entirely devoid of any chitinous markings, so characteristic of other pupae in the family. This may have some correlation with their habit of transforming in an earthen cocoon. From the two species which have been studied it is impossible to draw specific differences.

\section{PRIONUS CALIFORNICUS Motschulsky}

[Pl. XXXVI, fig. 2]

Pupa: The pupa of this species cannot be distinguished from $P$. imbricomis. It is likewise totally glabrous and devoid of any spines.

The described specimens were collected at Missoula, Montana, by Josef Brunner. The larvae feed on the roots of Amelanchier and Rhus, of ten killing the plants.

1 For description see Craighead (6). 


\section{sulfomily ÁLMIINAE}

Comedering the trpical menera inchuded in 1.eConte's group Asemi, the 1:114.16 form a sharply ilefined series; hut with the consideration of Tetropium, dowir must le inchuled and the less closely related (by larval characters) genns () psmols. Thomph this last gemus is indicated the transition to the Ceramhochate, from whide sulfinnily it ean be separated by only one character. As a) whe the Ineminase present at the same time strong affinities to the Lepturinae and thromgh . llimin show a well-graduated transition to that subfamily. In fact the Dervelalini could be as well placed with the Aseminae as in the true l.eptintinar.

The present consideration is hased on the following genera: Asemum, (rincephatns, Nothorhina, Sipondylis, Tetropium, Atimia, Paratimia, and ()psimis.

\section{GENERAL HABITS}

111 species of the Aseminae, so far as known, are confined to the coniferous trees. II ith several exceptions, they have very similar habits and on this basis can he divided into two groups which eoincide more or less closely with those biscel on the larval characteristics. The species of A semum, Criocephalus, and Vothorhina can be said to be wood borers mining under the bark but a very short time; in 1 semum moestum entering only the sapwood, but in other species the deep heartwood. Pupation normally takes place in the wood. The larval mines are elosely packed with mixed granular and fibrous frass. Species of the gencra Tretropium and Atimia are strictly bark feeders, spending the whole larvalstage between the bark and wood. Pupation occurs in the outer sapwood or hark. Their mines also are tightly packed with frass which, however, is more gramular than in the case of related forms. Opsimus is more strictly a sapwool feeder, but a short part of the larval period is spent between the bark and wool. Paratimia has the peculiar habit of mining in dry, seasoned pine cones (Timus).

1 rather large amount of moisture is requisite to all species, except probably Puratimia. Trees which have practically dried out are never attacked. This is especially true of Atimia, which attacks the cedars on which the bark dries quickly. IIany of the species feed only in the stumps and portions close to the ground. In upright tree is seldom attacked, except at the base, but if felled the whole trunk is liable to injury.

The oviposition of those species in which it has been observed (Asemum, (rincephalus and Atimia), is accomplished by merely inserting the egg in deep erevices of the bark.

Two species of Tetropimm are of economic importance, as they attack living or weakenel trees under favourable circumstances. Great numbers of Tsuga, Larix, and Abies have been reported killed by these insects.

Paratimia, Atimia, and Opsimus pupate in the fall, over-wintering as adults. All other species transform in the spring.

\section{('HARA('THRIZATION OF LARVAE OF THF' SUBFAMULY ASEMINAE}

\section{The characters of the Aseminae may be summarized as follows:}

Head transwerse; dorsal margins of epicranial halves behind front fused almost to base, rounded behind; tentorial cross-arm internal in a plane at right angles with hypostoma (i.e., oce ipital foramen not apparently divided into an anterior and a posterior porion).

Wandibles cumente from side, eutting edge broadly emarginate, having the dorsal angle rounted or flattened (except in $O p s i m u s$ ), apex produced aeute.

Eipistome not produeed over elypeus, five to many epistomal setae. Clypeus trapezoilal, filling -paee between the dorsal condyles of the mandible. Labrum transverse, semicireular or subeordate

Inxilla movable; carilo visible; maxillary artieulating lobe full; ventral mouth-parts attachert to hypostoma for nearly its entire breadth; palpifer large, disinet, bearing lacinia.

Intemac frail, short, very retractile. 
Eusternum of prothorax distinct, triangular; presternum and epipleurum fused; coxal lobe small, opposite sternellum. Mesothoracic spiracle not protruding into prothorax. Legs moderate in size, slender.

Abdominal ampullae with two lateral impressions on cach side; regions bearing spiracle distinctly defined, elliptical; hypopleurum large; coxal lobe small; epipleurum protulserant only on seventh, eighth and ninth abdominal scgments; pleural disc never present.

\section{KEY TO THE GENERA AND SPECIES OF ASEMINAE}

Labrum as long or longer than wide; dorsal angle of mandibles flattened into a triangular

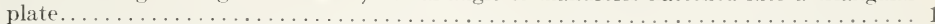

Labrum wider than long, transverse, dorsal angle of mandibles simply rounded . . . . . . 2

1. Asperities of pronotum ${ }^{1}$ coarse; caudal spines acutely conical, nearly contiguous at base, usually slightly incurved.

Asperities or pronotum finer; caudal spincs either bluntly conical, contiguous at base, or separate and shortly tubcrculate semum

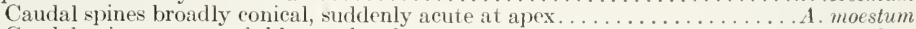

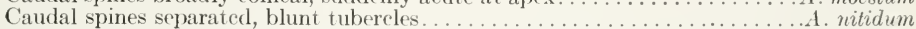

Asperities of pronotum finer; caudal spines flatly triangular, concave from behind

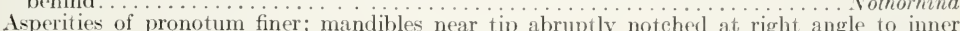
edge; caudal spines short, blunt, widely separate . . . . . . . . . . . . . . . .

2. Cutting edge of mandibles obliquely emarginate; lacinia nomal; two caindal spines. Caudal spines approximate; ampullae dull, covered with velvety pubescence. Tetropium Caudal spines fused, bifureate at tip.

Caudal spines separated, blunt tubercles.

Gena beset with dense bristles. T. cinnamopterum. Gena essentially glabrous.

T. velutinum

Caudal spines separated more than twice their length, incurved; ampullae glabrous, shining, deeply bilobed; pronotum posteriorly finely velvety pubeseent........ Atimia

Caudal spines straight, separated more than twice their height; ampullae not bilobed;

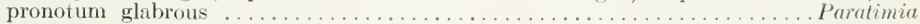

Cutting edge of mandibles rounded, gouge-like; lacinia lanceolate; no caudal spines.Opsimus

\section{ASEMUM Eschschotz, GRIOGEPHALUS Mulsant, and NOTHORHINA Redtenbacker}

The species of Asemum, Criocephalus, and Nothorhina cannot be separated generically as larvae. Without exception every character found either varies within the genus or is of only relative value and ean be recognized only in the species. Their similarity when a large series is studied is very striking. The best character of specific value is the shape and position of the caudal spines. In general it may be said that Criocephalus and Nothorhina are more robust and more densely haired. The asperities on the posterior area of the prothorax are much coarser and darker in colour and the glabrous spots more numerous in Criorephalus. The species may be collectively recognized as follows:

Head rather salient; labrum cordate, longer than wide; no ocelli; genal bristles long and dense; mandibles having ventral apical angle sharply acute and clorsal angle of cutting edge flatiened into a triangular, more or less striated plate; gula longer than wide. Pronotum posteriorly very fincly asperate or velured, as also the ampullae, but much less so.

\section{ASEMUM MOESTUM Haldeman}

\section{[Pls. VI, fig. 8, 12; XXY, fig. 1, 2]}

Form rather robust, anteriorly slightly depressed, posteriorly slightly comprested; integument thin, shining, sparsely covered with fine brownish pubescenee.

Head depressed, widest behind middle; mouth-frame strongly chitinized; epistoma roundly declivous, slightly curved. Labrum eordate, widest triangular from side, dorwal plate feebly striate. Intennae three-jointed, second and third joints equal; antennal ring open behind; ocelli absent; genal setae rather dense, reddish brown. Hypostomal plates large, trapezoidal, anterior margin thick, distinet and broadly curved; gula longer than wide, sutures coneave. Ventral mouth-parts fleshy; joints of maxillary palpi gradually shorter, basal largest, lasi labial joint equal to last maxillary; lacinia very slender, eylindrical; mentum wider than long.

Prothorax trapezoidal, widest in front; a chitinized light ochraceous band across anterior margin of protergum, widening laterally, and two triangular plates on epipleurum; pronotum

${ }^{1}$ These asperites on the pronotum in $A$ se $m u m$ moestum and 1 . atrum are individually distinguishable as fine points with a Zeiss 4 eyepiece and Ao objective, while in $A$. nitidu $m$ they cannot be so separated but blend together. In $C r$ ocephalus they are distinguishable with a $20 \mathrm{X}$ hand lens; in . Hothoirna they are similar to 1 . nitidum. 


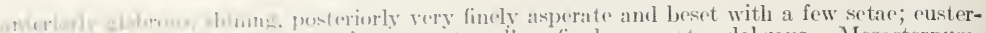

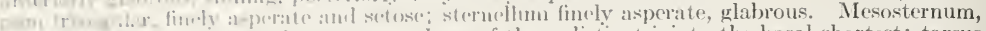

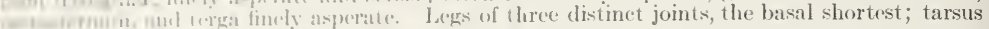

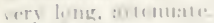

Ifoi in he:armg ampultae on seven segrnents, these very finely asperate, impressed by a

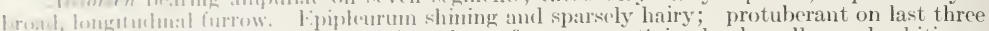
gments, tuberete hroully oval, bearing about five setae. Sipiracles broadly oval, chitinous rmmmel. ('ambil spmes contiguets at base, large eonical, then suldenly aeute at apex. Anus

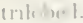

P'um: Form as in adult. Promotum anteriorly bearing a few minute ehitinous points; me vmofmm,mutanotum, and first abdominal segment marmed; ablominal terga bearing two gromps of dritmous points in a transverse row; caulal segment armed with two slender, aeute, memrved spines.

The larva of this species breeds in Picea, Larix and Abies throughout castern and central North America. It attacks dead trees, preferably shortly after their death. The mines are constructed under the bark for a short distance, then into the sapwood. rarely penetrating more deeply. The pupal cell is either made in the bark proper or in a long cell in the sapwood parallel to the grain. The life cycle is completed in one or often two years.

lackirl (23) has lescribed A semum moestum, but evidently he has confused this larva with that of some other species. The description indicates a species of leoclytus.

ASEMUM ATRUM Esehseholtz

[Pl. VI, fig. 1]

Some typieal forms from the Pacific slope can be recognized by the gradually conical, acute caulal spines, but all intermediate grades are found between these and the true moestum.

[Deseribed from speeimen Hopk. U.S. 11065b.]

Habits similar to A. moestum, of which it is supposedly the western form, oceurring throughout the Sierra and Rocky Mountain regions of North America. It has been found in Picea.

\title{
ASEMUM NITIDUM LCConte
}

\section{[Pls, II, III, VIII]}

Distinguished from A. mocstum by the larger size of matured larvae, the finer asperities on the prothorax and ampullae, and the longer genal setae. The eaudal spines eonsist of two very short, blunt tubereles scparated a distance equal to about twice their height.

[Deseribed from speeimens Hopk. U.S. 9014a.]

I'upa: Distinguished from that of A. moestum by the coarser points on the pronotum, as well as on the metanotum. All abdominal segments bearing mueh coarser chitinous points, clusely and irregularly disposed. Caudal spines nearly contiguous at tip.

The larva of this species has been collected from Abies, Pseudotsuga, and Pinus. It is more of a heartwood borer than A. moestum. The adult flies from May to July in the Pacific Coast region. Observations by Dr. A. D. Hopkins and Messis. H. E. Burke and B. T. Harvey.

\section{CRIOCEPHALUS Mulsant}

From a series of several hundred specimens two species can be distinguished by the larvae, both of which have been reared. One is eastern, the other western

\section{CRIOCEPIIALUS PRODUCTUS LeConte}

\author{
[Pls. II, III, VI, XXIII, XXV]
}

In gencral as deseribed for A. moestum, but readily distinguished by the much coarser asperitis of the pronotum and the numerous interspaced glabrous spots. Mandibles robust, clorsal plate of cutting edge strongly striate; genal bristles more dense; asperities of ampullae of about same texture as those on the prothorax of 4 . moestum. Caudal spines acutely conical and slightly incurved (curved toward each other). Fom more robust and densely pubeseent.

Pupa: Resmbles that of $A$. nitidum except that the prothorax is sparsely and regularly covered with fime whitish pubescence.

[I escribed from specimens Hopk. U.S. 11076 $a^{1}$ and 9528.] 
This species, occurring throughout the Rocky Mountains and the Pacific Coast regions attacks dying and dead species of Pinus, Abies, and Pseudotsuga. It is strictly more primary in its attack than A semum, being often found mining under the bark of trees infested by Dendroctonus long before the leaves begin to fade. The larva is more of a heartwood feeder, probably living in this stage at least two years. The mines are tightly packed with fibrous frass. The adults have been collected from June to August.

\title{
CRIOCEPHALUS OBSOLETUS Randall
}

This species averages smaller in size than in $C$. productus, the asperities are finer, and the pubescence much finer and yellowish white instead of reddish brown as in $C$. productus. The chitinized portion of the proalar area is nearly glabrous. The eaudal spines are on a common base and slightly compressed.

[Described from specimens Hopk. U.S. 9733 and $11 \mathrm{~s} 74 \mathrm{c}$.]

The larva mines in the stumps of eastern species of Pinus, near the surface of the ground and down into the roots. The work is similar to that of C.productus. The adults appear during June and July. Observations by W. F. Fiske and the author.

\section{CRIOCEPHALUS MONTANUS LeConte}

Specimens cannot be distinguished from those of C. obsoletus. It has been reared from Pinus ponderosa.

NOTHORHINA ASPERA LeConte

\author{
[Pl. VI, Fig. 10]
}

Form and pubescence as in Criocephalus productus. Caudal spines sharply triangular, flat, concave posteriorly, situated on a common projecting base. Epistoma abruptly declivous; second antennal joint longer than third; mandibles more robust, dorsal plate strongly striate. Asperities of pronotum and ampullae similar in texture to those of $A$. moestum. Pleural tubercle rather densely hairy.

[Described from specimens Hopk. U.S. 12674a.]

This larva has been found only in dead heartwood of Pseudotsuga, in Rocky Mountain and Pacific Coast regions. The galleries are tightly packed with fibrous frass. Adults fly from .July to September. The larva is described from specimens collected in Colorado by Mr. A. B. Champlain.

\section{SPONDYLIS Fabricius}

$$
\text { [Pls. I, III, VI] }
$$

The writer has not seen any specimens of this genus, but places it here following Perris. Perris's description is utilized and from it the characters are taken as given in his table in "Larves des coleopteres." Judging from the remarkable similarity between European species of Tetropium. Asemum, and Criocephalus which the author has compared with our American forms, the characters given here will hold for spondylis upiformis. The figures are from Perris.

The adults of our species have been collected from dead logs of Pinus in the western United States and British Columbia. It flies from May to July.

\section{TETROPIUM Kirby}

Form rather short; robust; pubescence fine and short. Head less salient, depressed; labrum transverse; mandibles short, robust, apex blunt, dorsal angle of cutting elge rounded or bluntly toothed, not flattened; last joint of maxillary palpi sharply conical; gula very short, transverse. Pronotum posteriorly very finely asperate or rather velvety pubeseent, ampullae also velured. Caudal spines either short, blunt, and approximate or projecting and bifurcate at tip. 


\section{TVTR()PILM CINNAMOP'TERUM lïrby}

[l's. I1, li]

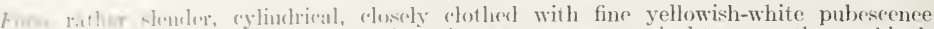

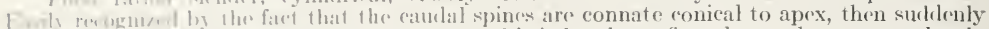
lat re lidormu ilemsely hairy in front; genal bristles short, fine, dense; hypostoma rleeply

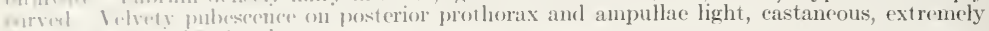
tume spurates orlueular, large.

fopt form as in adult. Pronotum sparsoly beset with chitinous-tipped papillae; mesonotum imul metilutum rlabrous; ablominal terga beset with a posterior band of chitin-

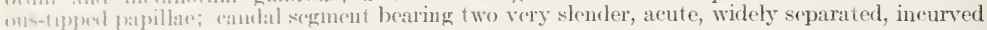
$\rightarrow$ inl1,

[1) weribed from specincu Hopk. U. S. 973.4.]

'The larvae feed only in dead trees. They have been collected from Abies bulsamea, l'ims, and l'irea. The mines are constructed entirely under the bark until the short pupal cell is mate in the outer sapwood or bark. Its range ixtemls through the castern and northwestern North America. Adults have leen collected from June to sieptember.

\section{TETROPIUM VELUTINUM LeConte}

\section{[Pl. VI, XIV, XXII]}

Form more robust than $T$. cinnamopterum: (epistoma more abruptly declivous; labrum antirely covered with hairs. Pronotum and ampullae more darkly though less densely velured. ('inulil spines minute chitinous tubercles separated little more than their length.

P'upa: From the specimens studied this pupa can not be distinguished from that of cinnamopterum.

[Deseribed from speeimens Hopk. U.S. 1190sa and 1262S.]

This insect is of considerable economic importance, causing the death of Tsuga heterophylla and Larix throughout the Rocky Mountains and the Pacific ('oast region. It has also been found in Pseudotsuga and Pinus. The larvae mime between the bark and wood, entering their pupal cells construeted in the outer sapwood or bark late in the summer. The adults fly from May to August. II (b) describes the work of this insect.

\section{TETROPIUM ABIETIS Fall}

\section{[Pl. III, VIII]}

Distinguished from $T$. velutimum by the almost total absence of genal bristles and the shining glabrous spot on the center of the labrum. The form is slightly more robust.

I'upa: Easily recognized by the absence of papillae on the pronotum and the coarse, very chitinous ones of the dorsal abdominal segements.

[1)escribed from specimens Hopk. U. S. $10597 \mathrm{c}$.]

This Totropium is also of economic importance, killing species of Abies at high elevations throughout the Pacific Coast region. Its habits are similar to those of vetutinum, and it is probably often confounded with that species. It rarely pupates in the sapwood, but usually in the inner bark. The adults fly from April to August.

\section{ATIMIA Haldeman}

IIterl not very salient, depressed, widest slightly behind midkle; labrum transverse, fleshy; mandibles more slender than those of Tetropium, apical and dorsal portions of eutting edge roundwh. latter slightly toothed; genal setae very long and slender; one pair of ocelli. Pronotum very fincly velured behind exeept for an irregular central area. Ampullae glabrous, shining, fourth, fifth and sixth deeply bitoberl, giving abdomen a four sided form. Caudal spines short, acute, in urve 1, separatel more than twice their length.

\section{ATIMIA DORSALIS LeConte}

\section{[Pls. III, VI, VII, XXIII, XXV]}

Form elongate, semi-robust, anteriorly slightly depressed; integument thin, shining, very sparsely clothed with short whitish pubescence. 
Head depressed; ocelli sometimes nearly obsolete; epistoma thin, curved; hypostoma transverse; gula very short; ventral mouth-parts fleshy, palpal joints subequal.

Prothorax about twice as wide as long, with an anterior, dorsal, transverse, light ochraceous band divided into four plates extending across protergum; pronotum anteriorly shining, posteriorly ly very finely velvety pubescent except for central area (pubescence sometimes nearly obsolete): eusternum having a narrow, transverse, posterior band of velvety pubescence. Mesonotum and metanotum extremely finely velured.

Abdomen shining; ampullae rarely at all pubescent, fourth, fifth and sixth deeply bilobed, these lobes tending to be tubereulate. Apiracles small, middle abdominal ones orbicular. Caudal spines two, widely separated.

[Deseribed from specimens Hopk. U.S. 4240g.]

The species of Atimia are found only in the Cupressae. The larvae of this species mine under the bark of recently dead trees, pupating and transforming to adults in the late summer, but not emerging until spring. A.dorsalis has been reared from Cupressus, Juniperus, and Libocedrus through the Pacific Coast region. Observations by Messrs. H. E. Burke and J. M. Miller.

\title{
ATIMIA CONFUSA Say
}

This species can only be distinguished from A. dorsalis by the more slender form and by its different distribution.

Pupa: Form, as in adult. Beset with short, stiff hairs as follows: Several groups of three on front of head; finer ones around perimeter of pronotum; two groups on mesonotum and metanotum; a transverse row on each abdominal tergum, denser on second and third. Caudal spines reflexed.

[Deseribed from specimens Hopk. U.s. 9483 and 11820.]

This larva has been taken in Jumiperus, Thuja, and Chamaecyparis. Two broods of adults occur each year: one in early spring and the other in early fall. From eggs laid by the spring brood some adults appear in the early fall, some larvae over winter and transform to adults for the early spring flight, and sometimes a few larvae live until the following fall before they transform. The fall brood shows the same irregularity of development.

\section{PARATIMIA CONICOLA Fisher}

\author{
[Pl. VI, XL]
}

Form semi-robust, anteriorly depressed; integument firm, shining, very sparsely covered with short whitish pubescence.

Very closely resembling Atimia, from which it is distinguished by the absence of any veluring on prothorax or body. Pronotum trapezoidal, widest behind, smooth, glabrous, shining. Ampullae prominent, projecting, shining, not bilobed, marked by a transverse furrow. Caudal spines separated about three times their height, very attenuately acute, straight, projecting dorsally

[Deseribed from specimens Hopk. U.S. 10856d.]

The peculiar habits of this species were liscovered by Messis. J. M. Miller and P. D. sergent. The larva feeds in the dry, dead cones of Pinus attenuata, boring through pith seales and seeds. Adults were found in the pupal cells in October. Collected at Watdo, Oregon.

\section{OPSIMUS Thomson}

This genus forms a distinet transition between the Aseminae and the Cerambycinae. The ventral mouthparts are fused to the whole width of the hypostomal plates; the clypeus extends out narrowly to the dorsal condyles as in the Aseminae, but is much shorter. The lacinia is borne on the palpifer, which is large and also bears the palpi as in the Asemimae. The mandibles have the gouge-shaped cutting edge typical of the Cerambycinae. The eusternum is triangular and listinct.

OPSIMUS QUADRILINEATUS Mannerheim

\section{[Pls. III, VIII]}

Form subquadrate, elongate, slightly tapering; integument thin, white, shining; sparsely covered with fine lemon-yellow hair.

Head transverse, gradually widening behind, narrowest in front, exposed surface brown, chitinized excepting hypostoma; clypeus and labrum thin, latter twice as wide as long; mandibles $57951-3 \frac{1}{2}$ 


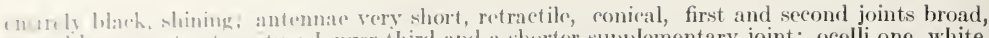

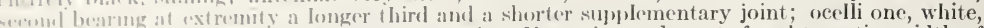

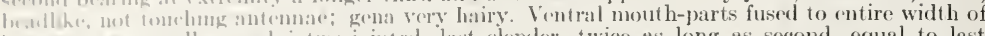

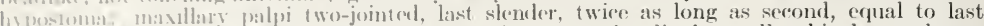

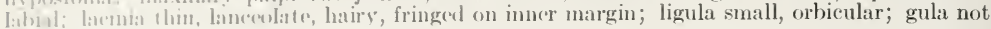
(1) $-1,121: 1$

P'rolherax slightly ilepressed; pronotum rectangular, posteriorly dull, fincly granulate, suteruty hairy; lateral sutures complete, no median suture, eusternum triangular, dull; sternellar folif not ilistinet. Iargless.

Impullu dill, not definitely marked, the first three pairs flat, the fourth, fifth and sixth mojerting ame somewhat hilobed as in ltimia. Spiracles clistinet, chitinous-rimmed, thoracic (1):al, alufeminat orloicular.

i) (xoribed from specimens Hopk. U.s. 11043a.]

This larva bores in sound, recently dead, or dying branches of Picea, Abies and Tsueq, and old fire-sears. The mines are extended principally in the sapwood, where pupation oceurs in the fall of the year. The insect overwinters as an adult, flying from April to May. It oecurs in Oregon, Washington, British ('olumbia ind bordering regions.

\section{Subfamily CERAMBYCINAE}

The larvae of the Cerambyeinae as here considered form a sharply defined group. Most systematists include in this group the Aseminae and Lepturinae, each of which has been treated here as of subfamily rank. Including such groups it would be necessary (by larval characters) to treat all other cerambycids excepting the Lamiinae as belonging in one subfamily.

They are most readily recognized by the short mandible having a rounded, gouge-like cutting edge and the small clypeus not filling the space between the dorsal articulations of the mandibles. They usually have fairly-well developed legs, but in some genera and species these are lacking. The larvae are quite hairy or pubeseent. This is a large subfamily showing many variations in hiological and anatomical structures.

The characters of the Cerambycinae may be briefly summarized as follows:

\section{CIIARACTERIZATION OF LARVAE OF THE SUBFAMHLY CERAMBYCINAE}

IIead transverse; dorsal margins of epicranial halves behind front fused for some distance, later separating, angulate; tentorial cross-arm lowered in a plane parallel to hypostoma (i.e., oceipital foramen apparently divided into an anterior and a posterior portion).

Mandible short, trapezoidal, cutting edge gougelike, never having apex or dorsal angle producesl.

Epristoma not produced over clypeus, two setae on each side; clypeus narrow, not as wide at bats as epistoma; labrum small, usually more or less circular.

Inxillne moreable; cardo distinct; maxillary sclerite full; ventral mouth-parts attached to hypostoraa by little more than width of gula; palpifer small; lacinia borne on stipes.

intennae quite salient, rarely entirely retractile.

P'rothorax having presternum and epipleurum often fused, sometimes distinctly separated; eusternum rarely distinct; coxae small, opposite sternellum. Postnotal fold usually present. Mesothoracic spiracle not protruding into prothorax. Legs either wanting or developed.

Abdomen having an elliptical region surrounding the spiracle, protruding and well defined; epipleurum protuberant only on last three segments; pleural dises present; hypopleurum large; coxal lobe small.

\section{ARTIFICIAL, KEY TO THE GENERA OR TRIBES OF THE CERAMBYCINAE}

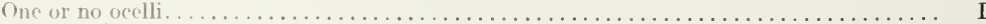

Twi 0 elli

Three ocelli.

I.

Fena not shouldered. . .

Ciena more or less shouldered, enclosing ocellis . . . . . . . . . .

1. Postnotal fold behind prothorax absent; antennae conical................ Methini, Oemini

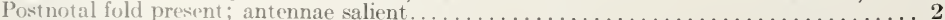

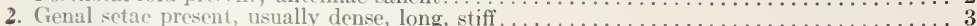

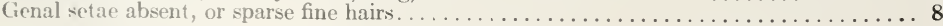


3. Pleural dises, large, cireular, finely granulate. . . . . . . . . . . . . . . . . . Pleural dises indistinet . . . . . . . . . . . . . . . . . . . . . . . 5

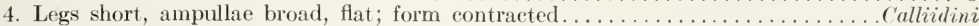
Legs slender, ampullae projecting, form elongate......... Elaphidion subpubescens and allies

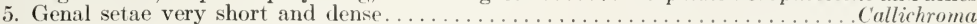
Genal setae very long, eurved.

6. Last joint of maxillary palpi longer than seeond.

Last joint of maxillary palpi not longer than second . . . . . Elaphidion subpubescens and allies

7. Hypopleurum of abdominal segments laterally protuberant; skin between several middle ventral ampullae distinctly rugulose.

Curius and Euderces

Hypopleurum normal or ventrally protuberant with ampullae; ampullae usually strongly bilobed; skin between segments not rugulose

8. Pleural dises, distinet, circular, either having a deep pore or finely granulate......... Pleural dises indistinct; femur plus tibia shorter than maxillary palpi . . . . . . . . . . 12

9. Yellowish presternal plates of prothorax distinet.................... Malocopterus

Presternal plates absent

.10

10. Prosternum never more than twice as wide as long (i.e., between notchlike ventro-lateral

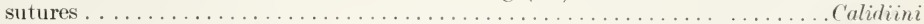

Prosternum more than twice as wide as long (i.e., between notehlike ventro-lateral sutures. . . . . . . . . . . . . . . . . . . . . . . . . . . . .

11. Prothorax somewhat depressed; ampullae flat; form not elongate............. Heterospini Prothorax quadrate; ampullae strongly protuberani; form elongate. Elaphidion subpubescens

2. Eusternum distinet, triangular, shining and allies

Eusternum not distinct.

Simodicum

13. Pronotum not striate or, if so, having the median suture deeply impressed.

Pronotum striate, no median suture

14. Pronotum about twice as wide as long; last joint of maxillary palpi longer than second

Pronotum but little wider than long; last joint of maxillary palpi not longer than second

15. Yellowish presternal plates of prothorax present.

Yellowish presternal plates of prothorax absent

16. Metanotum having $\mathrm{x}$-shaped impressions

Metanotum having a single transverse impression

Araglypti

. Pleural dises finely granulated, or a deep pore

Pleural dises indistinct, obstructed by a tuberele

Tylonotus Stcnaspini

Phoracanthini

8. Prosternum between notch-like ventro-lateral sutures, not twice as wide as long. Callidiini. Prosternum between notch-like ventro-lateral sutures more than twice as wide as long.

Ileterospini

19. Both ventro-lateral and median dorsal suture of pronotum impressed. Neither ventro-lateral nor median dorsal suture of prothorax impresised.

. Metanotum with a single transverse suture

Metanotum with $\mathrm{x}$-shaped sutures.

Anaglypti

Eburiini

Phoracanthini

Postnotal fold (behind prothorax) absent; antennae conieal

Postnotal fold (behind prothorax) present; antennae salient

IIaplidus

1. Metanotum having $\mathrm{x}$-shaped sutures

Metanotum having a single transverse suture.

2. Pleural dises finely granulate.

Pleural dises indistinet, obstrueted by at tubercle. . .

3. Ventro-lateral sutures of prothorax absent

Ventro-lateral sutures distinet, widely diverging anteriorly

Phoracanthini

.......... 2

(yllenes (rarely)

Ibidioni

Rhopalophora

III

Ocelli sharply defined; median suture of pronotum impressed

Ocelli often indistinet, or fused; median suture of pronotum not impressed........ ("yllenes

\section{SMODICUM Haldeman}

Most writers, in discussing the adult of this genus, agree that it is an aberrant form and place it at the beginning of the Cerambycinae. The larva is likewise perplexing, not from any peculiarities of structure but because of a striking absence of any definite characters which might give a clue to its relationship. It is typically a cerambyeine, but in some respects sugesests a prionine. The rather distinet triangular eusternum suggests the Aseminae, and allied forms. On the strength of this single character and the opinion of 
the andt ststomatists it is retained here. The correlation in form between litrian and alults so often seen in the ('orambyeidae does not hold in this species. The depresorl adult sugerests a hark-feeder, while the larva is eylindrical and mines 111 solicl woorl.

\section{SMODICUM CUCUJIFORME Say}

\section{[Pl. XVIII]}

Form eylindrical, slender, slightly tapering; integument thin, white, and shining, sparsely covered with very fine white hair.

Head suborbieular, a sudelen constrietion at base, rather abruptly broad in front; mouth frame white, never corneous; clypets and labrum small, fleshy, later transverse; mandible short, hatsal half light, distal piceous, having a groove on outer face; antennae fleshy, first and second joints subequal, short, about as long as thick; one small black orellus contiguous to base of antemae. Ventral mouth-parts white, fleshy; last joint of maxillary palpi one and one-half times the length of second; lobe of palpifer minute. (iula narrow, sides slightly eoneave.

Thothorax quadrate, tergal plates dull lemon-coloured; pronotum square, posterior area shining, fincly, irregularly striate, median suture not impressed. Sternum fincly hairy; eusternum distinet, triangular, glabrous; poststernellar fold not distinet at extremities, fused into rpipleurm; ventro-lateral suture not impressed. Mesonotum and metanotum not distinetly impressed by sutures. Legs minute, three-jointed, shorter than maxillary palpi.

Ibdomen: Ampullar prominent, small, shining alutaceous; inter-segmental skin long, ampullae witely separated. Pleural dises distinet on three segments, not distinetly granulate. spiracles minute, orbicular, peritreme thin.

[Described from speeimens Hopk. U.S. 9791 n.]

This larva is a typical heartwood borer in very old dry and seasoned wood of Quercus and Hicoria. Its work is often found under old fire-scars on oaks, where the larvae bore in connection with Eburia quadrigeminata, completely honeycombing the heartwood. The mines are tightly packed with granular frass. The larva sometimes attacks seasoned products. The adult flies in June and July throughout the eastern United States. Hopkins records the adults under bark of Fagus, Clmus and Gleditsia in West Virginia. Observations by A. 13. ('hamplain and the author.

\section{Tribes OEMINI and METIINI}

The following five genera, Oeme, Haplidus, Dysphaga, Methia, and Idoemea, undoubtedly show close affinities and here are grouped together. This (loes not mean that they are to be considered as one tribe, but as only a few of the larvac in these groups of adults have been studied and two of the genera have not been reared (Haplidus and Methia), they are so grouped for the present. Oeme and Inysphaga each show characters of distinct tribal value. The species of Oeme show important affinities to the Aseminae and are considered as related to them.

They may be recognized by the slender form and depressed prothorax; antennae short and conical, retractile; antennal ring bisected by rather distinct frontal sutures (in Oeme); genal setae ustually dense; stermum broad and not very long; ventro-lateral sutures obliquely impressed, diverging anteriorly; eusternum often faintly indicated by sutures; prosternellar fold strongly fused into epipleurum at extremities; no median pronotal suture; fold behind pronotum wanting; mesonotum and metanotum each with a transverse suture; legs very short, conical, three or four jointed; pleural dises a deep pore (in Oeme), or indistinet.

The following key will separate the described genera:

\section{KEY TO THE GENERA OF OEMINI AND METHINI}

Head not bearing a short carina behind ventral articulation of mandible.

Articulation of submentum to gula sunken below anterior edge of hypostoma.

Genal setae dense, conspieuous.

Genal setac

Irtichtation in line

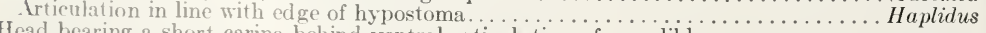

pad bearing a short carina behind ventral articulation of mandible.

Process of palpifer indistinct

Proees of 
OEME Newrnan

The species of Oeme are very similar by larval eharacters. They can we recugnized as follows. Head subtriangular, widest behind; antennae short, conical, retractile; one ocellus; genal bristles dense; submentum deeply and suddenly sunken below anterior margin of hypostomal plates and fused with fleshy gula; prothorax depressed, transverse; no median suture on pronotum; postnotal fold absent; ventro-lateral sutures oblique, widely diverging anteriorly; sternellar fold not distinct at extremities; pleural dises conspicuous; dorsal ampullae with two lateral and two transverse impressions, wider in middle; legs short; form slender.

The larvae of this genus breed in the dead wood of the Cupressae and one species of Pimus. All, so far as known, complete the life cycle in one year The younger larvae mine beneath the bark, exuding much granular frass. Shortly before pupating they enter the sapwood or heartwood, where a characteristic cell is constructed. At the outer extremity of this pupal cell a disc of wood is left, perforated in the center, which partly eloses the cell.

\section{KEY TO THE SPECIES OF OEME}

Labrum orbicular, body hairs silky ......................... rigida

Labrum transversely oval.

Ultimate joint of maxillary palpi equal to penultimate, body hairs coarser. Breeds

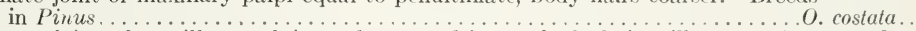

Ultimate joint of maxillary palpi equal to penultimate, body hairs silky ....... strangulata

OEME RIGIDA S'ay

[Pls. VIII, XX, XLII]

Form elongate, slender, cylindric; integument thin, shining, sparsely covered with long, light, castaneous hairs.

Head subtriangular, deprsseed, strongly tapering anteriorly; mouth-frame slightly corneous; clypeus and labrum thin, latter orbicular; mandibles black, shining, slightly constrieted near apex, basal piece indistinct; antennae short, retractile, conical, last joint slender, much longer than third, supplementary distinct; one black ocellus, not contiguous with antennae. Ventral mouth-parts indistinguishably fused by submentum with gula; process of palifer distinct, as also process on first maxillary joint; maxillary palpi short, conical, ultimate joint slightly shorter than penultimate, shorter than last labial; gula soft, deeply sunken below anterior curved edge of hypostomal plates; gena not shouldered, bristles dense, long and slender.

Prothorax transversely depressed, short, pronotum rectangular, of essentially same texture throughout, or slightly reticulated behind, no median suture; sternum shining, retieulated, ventro-lateral sutures widely diverging anteriorly; sternellar fold broadly fused at extremities into epipleurum. Nesonotum and metanotum with straight transverse impression. Legs short, conical, four-jointed, joints globular, femur and tibia shorter than maxillary palpi.

Abdominal segments elongate; dorsal ampullae alutaceous, shining, marked by two lateral impressions, a shallow median longitudinal furrow, and two transverse impressions forming a fusiform diamond-shaped area. Pleural dise faint on first segment, distinet on second and third, faint on fifth. Abdominal spiracles minute, oval, peritreme thin.

[Described from specimens Hopk. L.... $11847 z$ ]

The larva has been collected in Taxodium and Juniperus. A. B. Champlain records the adults ovipositing in the exit holes of Phloesinus, in Comnecticut, July 15. By October most of the larvae had constructed their pupal cells. W. F. Fiske has made a number of observations on this species in the south. He records two generations or an overlapping of broods in some localities, since he found adults in September.

\section{OENE COSTATA LeConte}

Distinguishable from rigida only by the coarser and more densely set liairs, of ten chitinous tarsus, usually white ocellus, and transversely oval labrum.

Pupa: The pupa is characterized by almost total absence of spines on the body. The tergum of the mesothorax has a small group of spines near the posterior median margin, and a transverse band of from six to eight small spines occur on the first three dorsal abdominal segments.

[Deseribed from specimens lfopk. U. S. 126i7a.]

The larval habits are similar to those of $O$. rigida. It is more commonly found in branches. It has been collected by A. B. Champlain from Pinus edulis in Colorado and by M. Chrisman from Pinus ponderosa in Arizona. 
()EME S'IRANGULATA Horn

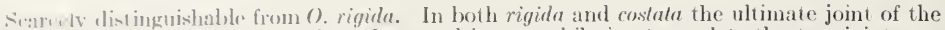
mavillary palpus is much shorter than the penultimate, while in strangulala the two joints are

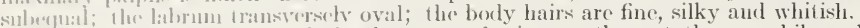

I'upe: 'The prupal cont irely lacks the group of spines on the metathorax, while cach ablominal segunent hears two small gromps on the anterior part of the dorsal surface.

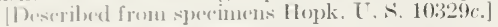

This latra has heen collected in the small branches of Cupressus and Juniunu in Arizonat ly M. ('hrisman. The aclult flies in June.

HAPLIDUS TESTACEUS LeConte

[Pl. IX, Fig. 6]

Fin $m$ very elongate, slender; integument rather firm, shining, sparsely covered with whitish hairs.

II cad transverse, twice as wide as long, rather broad in front, sides curved; mouth-frame searcely comeous; clypeus and labrum thin, latter transversely oval; mandible tapering, long, hatsil jicee short, about one-fourth length of distal, latter piceous, impression at base on outer fire: antennae sholt, retractile, third joint globular, fourth slender; ocelli two, black, prominent, enclosed by very abruptly shouldered gena bearing numerous fine, short, white bristles; ventral momth-parts fleshy, fused with gula; palpi long, slender, ultimate joint of maxillary palpi about twice length of penultimate, equal to last labial; gula wide, sutures strongly diverging behind.

Prothorax transverse; pronotum posteriorly finely rugulose with a tendenev to striation; sternal region smooth, shining; sternellar fold broatly fused at extremities into epipleurum Legs short, basal joint globular, second longer than third, tarsus twice as long as second.

Abdomen dorsal ampullae alutaceous, shining, marked by two lateral and two transverse impressions and a median longitudinal furrow. Sipiracles sub-rectangularly oval.

[Described from a single poor specimen, Hopk. L. S. 2779.]

The specimen on which this description is based was not reared, but collected and associated with the adult by A. D. Hopkins. It was working in the small dead branches of Pinus jeffreyi, in Ventura Co., California.

\section{DYSPHAGA TENUIPES Haldeman}

\section{[Pls. VIII, XXVI]}

Form eylindrie, slender, elongate; integument thin, shining, sparsely covered with short yellowish hairs.

Hearl transversely sub-orbicular, rather thick, mouth-frame light lemon-coloured, not strongly corneous; labrum fleshy, transversely oval; manclible rather robust and broad at apex, basal picce distinct, light, castaneous, slightly shorter than apical, latter piceous; antennae uninute, conieal, retractile; ocellus indistinet, white, oval; gena not shouldered, bearing a row of lito 4 very long, slender, recurved bristes. Ventral mouth-parts fleshy, last maxillary joint longer than second; process of palpifer absent; submentum sunken below anterior margin of hypostoma, fuserl with membranous gula; epieranium bearing a short prominent earina just below the ventral articulation of the mandible.

I'rolhorax subquadrate, depressed; pronotum rectangular, with a border of long hairs in front, posteriorly substriate, merging into dull fine granulations, no median suture; postnotal foll absent; eusternum faintly defined, triangular; ventro-lateral sutures impressed, widely divergent anteriorly; sternellar fold broadly fused at extremities into epipleurum; legs minute, about as long as labial palpi; tarsus not chitinized.

Abdomen: Impullae shining, granulate, with two faint lateral and one faint transverse impression; pleural dises indistinct. Spiracles orbieular, minute, peritreme not corneous.

Pupa: Slender, eylindrical, essentially unarmed execpt for a transverse row of doublepointed (one point extending anteriorly, the other posteriorly) chitinous spines on second, third, fourth, fifth and sixth abdominal terga; seventh armed with simple spines irregularly disposed, this segment also broadly enarginate below.

[Described from specimens Hopk. [.... 97s6d. $\left.{ }^{1}\right]$

The larva breeds in small dead branches of Quercus, Fagus and Hicoria, and is rarcly found in twigs over one-fourth of an inch in diameter. It completely hollows these twigs, forming pupal cells between two wads of frass. Pupation and transformation to adult occur in late summer or fall. Observations by A. B. Champlain and the author. Range, throughout eastern United States. 
METHIA PUSILLA Newman

[Pl. VIII]

Form, integument and body characters similar to those of Dysphaga. The larvae can be easily recognized by the processes of the maxillary palpifer and the first palpal joint, being well-developed and bearing long incurved setae, the latter being much heavier and extending beyond the palpus. The head tapers more in front than in Dysphaga; the labrum is orbicular, and the ocellus is black.

[Described from several poor specimens, Hopk. [. S. 1910h.]

The larvae on which this description is based have not been reared but were collected with adults by W. F. Fiske, who found it boring in very small branches of Taxodium, in Georgia.

\section{IDOEMEA sp.}

Form very elongate, slender; integument thin, shining, very sparsely elothed with very short, fine, whit ish hairs.

Head rather broad; mouth-frame not corneous; epistoma thin, fused with membranous clypeus whieh indistinctly fills spaee between condyles; labrum thick, transversely rectangular; mandible short, shining, basal half somewhat shorter than distal; antennae very short retractile; ocellus large, black, conspicuous (not protruding); gena not shouldered, having a row of five to six short setae above ocellus and another row some distance behind ocellus. Ventral mouth-parts little chitinized, first and second maxillary joints transverse, last equal to last labial, cylindrical; gula sunken below hypostoma as in Oeme.

Prothorax less than twice as wide as long; pronotum anteriorly densely beset with very fine short hairs, posteriorly finely reticulated to dull granulate behind; sternal region uniformly hairy, undifferentiated, sternellar band short, broadly fused into lateral regions at extremities. Mesonotum and metanotum and sterna dull granulate. Legs two-jointed, very minute, not longer than labial palpi.

Abdomen very elongate, slender; ampullae small, very widely separated, shining, very finely alutaceous, having two lateral and two faint oblique transverse impressions and a slight median longitudinal furrow' pleural dises distinet on five segments, surrounding area protuberant. spiracles minute, indistinct, orbicular; anal lobes protuberant, fincly pubescent.

[Deseribed from specimen Hopk. U.S. $12699 a$ and 7132 and $10650 \mathrm{r}$.]

An adult was reared with the last number. The other larvae have not been reared but were collected in twigs of Juniperus and Cupressus associated with the adult of Idoemea sp. by M. Chrisman, $7132 a$ at Paradise, Ariz., and $12699 x$ in the Catalina mountains.

\section{MALACOPTERUS LINEATUS Guerin}

\section{[Pls. XVIII, XIX.]}

Form elongate, cylindrical, slightly depressed; integument thin, shining, verv sparsely covered with short brownish-yellow hairs.

Head subtrapezoidal, stighily tapering in front; mouth-frame corneous, smooth, dark castaneous; elypeus and labrum fleshy, latter orbieular, shorily stalked, densely eiliate; mandibles tapering, longer than basal width, smooth, shining, basal piece redish brown, about onehalf length of apical piece, latter piceous, having a shori suleus on onter faee; antennae rather thick, joints subequal, supplementary minute; minute ocelliform tubercle; gena receding, not shouldered, sparsely haired. Ventral mouth-parts fleshy, a chitinous band across stipes; ultimate joint of maxillary palpi much longer than penultimate, slightly larger than last labial; process of palpifor minute.

Prothorax subtrapezoidal, with four chitinized tergal and two sternal plates; pronotum shining, length about two-thirds width, posteriorly finely reticulated to very finely rranulate, this area slightly raised and extending medially forward, median suture impressed anteriorly, faintly. keeled posteriorly; sternal region reticulated, shining ventro-lateral sutures impressed, eonvergent anteriorly. Legs shori, joints globular, basal largest, exehusive of tarsus shorter than maxillary palpi.

Abdominal segments elongating eaudally; ampullae transverse, oval, prominently projecting, dull, finely granulate, eaeh with a deep lateral impression and a shallow median longitudinal furrow, transverse impressions indistinet. Pleural dise distinet on first segment, faint on seeond thirel and fourth. Spiracles narrow, elliptical, peritreme thin.

Pupa: Form similar to that of adult; essentially glabrous exeept for a few conical chitinous. tipped points on dise of pronotum; also recurved points on first to eighth abdominal terga, most numerous on second, third and fourth; anal lobes bearing two or three recurvel points.

[Described from speeimens Hopk. L. s. 105:32b.]

All larvae and adults in the collections have been taken from dead sialix and Populus in Arizona. The larvae construct very long meandering galleries 
throngh the heartwood and sipwood, always packing them tightly with granular frass. The work resembles that of Neoclytus capraea in ash. Pupation occurs (leop in the woul, the atults cmerging late in the summer. It is generally ansociated with a specries of Aconthoderes and one of Elaphidion, both of these working in the decitying sapwood. Range, throughout southwestern United siate. The specimens were collected by M. ('hrisman.

The adult of this species is generally associated by systematists with Oeme, hut the latrat has fow characters in common with the latter and in fact srems to be quite isolated in the subfamily.

\section{Tribe CALLIDIINI}

The larvae of the Callidizi with one exception (Hylotrupes bajulus) form a homogeneous and natural group. They can be distinguished by a group of characters usually very constant. The legs are relanively short, three or four jointed, the coxa very small, and the joints more or less globular: cxclusive of the tarsus they are never longer, usually shorter, than the maxillary nalpi; the ma xillary palpifer bears a distinct fleshy process on its lateral face nearly as long as or longer than the last joint of the maxillarv palpus; a similar process is borne on the first joint of maxillary palpus, though shorter. A distinct pleural disc is present on three to six abdominal segments. It his a deep pore surrounded by a dull granular area. The prothorax is rather thick and hairy, the hairs of the lateral region are never of two forms, the pronotum is never twice as wide as long, and the median suture, often partially impressed, is never complete; the sternum is broad and never differentiated (i.e. into presternum and eusternum) and is fused with the hypopleurum and the epipleurum into one broad area; the ventro-lateral sutures are never impressed; the median central areat of the sternum has two circular glabrous spots of contrasting texture; the sternellar fold or area never passes the spiracles and the extremity is usually indistinct and fused into the lateral region. The mesonotum has no distinct $x$-shaped impression but only the scutellum chistinct; the metanotum has a single transverse impression. The ampullae are broad, ustally gramulate when marked, having two lateral, an anterior connecting transverse, and sometimes a posterior transverse impression. This last one is never complete. The intersegmental skin is very short, thus giving the larvae a more or less contracted, robust form.

In this group) a study of the larvae indicates that the formation of genera has been carried too far. In many cases it is impossible to recognize the genera, especially if they contain several species. Thus it would seem that only three distinct groups of genera of larvae oceur, one consisting of $I I$. bajulus, which is with difficulty included in the Callidiini. It has a distinct triangular eusternm, the mesonotum and the metanotum each with an inverted v-shaper impression (i.e. scutellum distinet) and no pleural dises. All writers agree in the position of the adult, hence it will be retained here and may be a radical case of development due to its peculiar habitat. Another generic group would include the two species of Hylotrupes ligneus and amethystimus, and those of Callidium and Phymatodes in which the sides of the head recede from the antennae (i.e, are not shouldered). The species of Callidium and Phymatodes can not be separated generically: A third would contain those forms having the gena shouldered, inclosing the ocellus, and would include Callidium antennatum, C. janthinum, Physocneum, Gonocallus and Merium. IV ithin this last larval group several genera might be recognized, but it is doubtful if it could be done if they included more than one species.

The larvae show well-marked affinities to the Clytini and Anaglypti. In fact some of the species of Callidium superficially can be confused easily with Neoclytus, Clytanthus, etc., while Gonocallus and Werium resemble genera of the Anaglypti and many characters of $H$. bajulus are to be found in the species of Cyllene. The absence of pleural dises and the relatively shorter legs and process of the palpifer will mark off the Clytini-like groups.

These larvae likewise are similar in their habits. All are feeders on the inner layer of bark for the greater part of the larval life, going into the wood (sometimes the bark) only to pupate. All normally mature in one year. The exeeption is Hylotrupes bajulus, which lives in dry seasoned wood, and often requires many years to mature.

\section{KEY TO THE GENERA OR SPECILS OF CALLIDINII}

Three pairs of ocelli

One pair or no occlli.

Gena reeching from antennae, never shouldered so as to enclose the ocelli; ocelli one or none. Genal bristles short and lense; no ocelli; last joint of maxillary palpi shorter than second; pronotum not listinctly striate............. Iylotrupes ligneous, H. amethystinus.

Genal bristles absent or very long; one or no ocelli; last joint of maxillary palpi longer than second; pronotum usually striate......... Ropalopus, Callidium and Phymatodes.

Gena shouldered and more or less corneous, enclosing ocelli.

Anterior elge of hypostoma bearing four tuberculiform projections...Callidium antennatum and C.janthinum 
Anterior edges of hypostoma smooth or merely roughened.

Subfossal spine indistinct.

Subfossal spine conical, acute.

Epicranium not bearing a distinct tubereuliform carina above antennae.

Pronotum having a median suture impressed on posterior half; body hairs

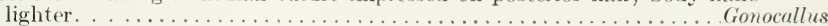

Pronotum with no median suture; body hairs eastaneous. . . . . . . . . . . Merium

Epicranium bearing a distinct tubereuliform earina above antennae... . .

\section{HYLOTRUPES BAJULUS Linnacus}

Form rather robust, slightly depressed; integument thin, shining, very sparscly covered with very long yellowish hairs.

Head subtrapezoidal, widest behind; mouth-frame very slightly ehitinized (light lemon colour); epistoma swollen; clypeus and labrum fleshy, latter twice as wide as long; mandibles broad, basal piece light brown, distal black, shining, having a deep longitudinal impression ; antennae fleshy, first and last joints sub-equal, second much longer, supplementary minute; ocelli three, oval, projecting, usually black; gena somewhat shouldered, not setose; ventral mouth-parts soft, fleshy, last maxillary joint shortest, shorter than last labial; process of the palpifer distinct, not as long as last maxillary joint; gula narrow, sutures coneave.

Prothorax rectangular, depressed; pronotum but little wider than long, shining, anteriorly sparsely beset with long hairs, posteriorly smooth, shining, with a few irregular indistinet striae; median suture deeply impressed; eusternum distinct, glabrous, shining; sternellar fold not distinct beyond spiracles. Metanotum marked with inverted v-shaped impression. Legs short, four-jointed.

Abdomen: Dorsal ampullae rather prominently projecting, shining, coarsely sub-reticulate approaching tuberculate, having two lateral and two transverse impressions and a deep median furrow. Pleural dises indistinet, not granulate. Spiracles broadly oval, small, peritreme thin.

[Described from specimens Hopk. U.S. 9731 and 11866h.]

The larval habits of this species are very different from those of the other Callidini. It attacks dry-seasoned wood of conifers, excavating extensive galleries loosely packed with mixed, fine, powdery, small pellet-like frass, though a great deal of this is extruded. This species is of economic importance and many references in literature discuss its habits and the great length of its larval life. It often mines for years in a finished piece of furniture. Mr. George Dimmock has given me the following unpublished note: "Adult emerged from wood of microscope box June, 1885; this instrument was imported from Germany in 1881, first sign of work noticed by exuded frass in 1882."

The writer found the pine trestles of a railroad bridge completely destroyed by these larvae, necessitating their removal. It has been collected from Pinus and Picea.

\section{HYLO'TRUPES AMETHYSTINUS Leconte}

\section{[Pls. X, XV, XVIII, XIX, XXXIV]} hairs.

Form robust, sub-depressed; integument shining and sparsely covered with yellowish-white

Head subtrapezoidal, narrowing in front; mouth-frame dark brown, ehitinized; clypeus very short, labrum suborbicular, very thick, widest at middle; mandible entirely black, slining, without prominent basal piece; no oeelli; antemnae slender, first and seeond joints subequal, last very short; gena reeeding from antennae (not shouldered), bristles dense and short; ventral mouth-parts rather strongly chitinized; joints of maxillary palpi gradually shorter, last shortest, equal to last labial; process of palpifer large, longer than last maxillary joint.

Prothorax rectangular, twice as wide as long, rather densely and finely hairy; pronotum nearly twice as wide as long, anteriorly fincly rugulose, posteriorly rugulosely striate exeept for dull granulate posterior border, median suture faintly impressed; eusternal spots glabrous, eontiguous, ventro-lateral suture not impresserl. Mesonotum and metanotum dull, finely granulate, the former with an incomplete $\mathrm{X}$ and the latter with a transverse impression. Legs short, indistinctly four-jointed.

Abdomen: Ampullae broad and flat, dull, finely granulate or laterally alutaceous, bearing two lateral, also one complete and one incomplete transverse impression, the seventh ventral segment having a wrinkled eorneous, rugose plate at each side. Pleural dises distinet on first, sceond, third and fourth segments. Spiraeles large, oval, peritreme thiek.

Pupa: Head and thorax unarmed, but beset with a few short, stiff hairs on posterior border of pronotum and on metanotum; abdominal terga 1 to 5 , bearing two patehes of very short chitinous points in a transverse band, most numerous on second and thirl.

[Described from specimens Hopk. U.S. $4340 \mathrm{c}$ and $9032 d$.] 
Tine larva hreeds normally in species of Cupressus, working under the bark ami deeply searring the worl. It enters the wood only to construct a long prompal gallery. This is rarely constructed in the bark. The mines are lighty packed with gramulat frass. The life cycle is completed in one year. It has heen colloctod from C'upressus, Libocedrus, Thuja, and Abies. Range, in the Palcific ('otst and Rocky Mountain regions south to Arizona. H. E. Burke records it in one (atse attacking a living tree of Libocedrus.

\title{
HYIOTRUPES JUNIPERUS Fisher
}

This larva ean be separated from amethystinus only by the eoarse eastaneous body hairs.

1) hescribed from suecimens Hopk. L. . . 12698.]

Collected hy M. Chrisman in Arizona, attacking and killing living junipers. It constructs a very large pupal cell at nearly right angles to the axis of the tree.

\section{HYLOTRUPES LIGNEOUS Fabrieius}

\author{
[Pls, XXVI, XLIH]
}

In gencral similar to amethystinus, though smaller, differing in that the genal bristles are not so numerous; the pronotum is less rugose; the ampullae are entirely finely granulate, dull; and the last ventral ampulla lacks the lateral eorneous plates.

P'upa: Arrangement of spines as in amethystinus, but searecly chitinized and eaeh having a bristle.

The hahits of this species are the same as those of amethystinus. It has been recorded from Juniperus, Thuja, Sequoia, Tsuga, Libocedrus, Picea, i'seudotsuga, 1 bies, Larix, Chamaecyparis, and Pinus. Range, throughout North America. The numerous colour forms of the adults cannot be distinguished in the larva stage.

\section{PIIYMATODES Mulsant and GALLIDIUM Fabricius}

The following species of Phymatodes and Callidium cannot be separated generically in the larval stage. C. antennatum is quite distinct from these forms.

\section{KEY TO SPECIES OF CALLIDILU AND PHYMATODES}

Oeelli absent or not distinctly protuberant, often a blaek spot beneath chitin.

Median suture of pronotum not or faintly impressed................ Callidium aereum Median suture of pronotum distinetly impressed.

Genal bristles wanting. ..................... Phymatodes variabilis

(inal bristles long and numerous.

Pronotum posteriorly striate ................... nitidus

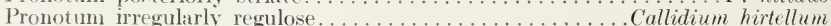

( )eclli distinetly protuberant, usually white.

second joint of antennae longer than first, first as long as wide.

Protergal plates distinct (orange).

I'rotergal plates not strikingly distinet.

Firacles orbicular, peritreme thin..... dimidiatus

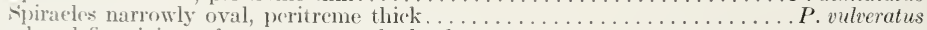

Fecond and first joints of antennae equal, slender.

Eastern.

IV estern

...P. varius

$\ddot{P}$. decussatus

CALLIDIUM AEREUM Newman

Pls. XV, XIX]

Form suberlindric, slightly depressed; integument firm, smooth, not very shining, densely covered with lemon-yollow hair.

Hrarl subtrapezoidal, gradually widening behind antennae; mouth-frame corneous, castancous to dirty black; labrum fleshy, transversely oval; mandibles about as long as wide at base, basal picee brown, narrow, one-third width of distal, latter piceous, shining, median inupression on outer face; antennal joints slender, seeond joint longest, supplementary slender, distinct; ocelli none: gena receding not shouldered, no bristles; ventral mouth-parts searcely coriaceous: lobe of palpifer distinet; ultimate joint of maxillary palpi twiee length of penultiniate, equal to last labial; subfossal spine absent; gular sutures parallel.

Prothorax roundly rectangular; pronotum one and onc-half times as wide as long, hairy on anterior lialf, posteriorly very finely and regularly striate, merging into finely granulate, median 
impressions faint, pronotal and proalar plates distinct, ochraceous; sternum undifferentiated, hairy, having a dull granulate band in centre, bordered by two glabrous shining spots. Mesonotum and metanotum dull, finely granulate. Legs small, four-jointerl, about equal to maxillary palpi.

Abdomen: Segments wider ventrally, ampullae with no definite transverse impressions, dull, finely granulate. Pleural dises distinct on first, second, and third abdominal segments. Spiracles narrowly oval, peritreme thin.

Pupa: Form similar to that of adult, pronotum bearing a small obtuse tubercle on anterior margin, unarmed except for an irregular row of a few tiny, short, acute, chitinous points on posterior margin of second to last abdominal terga.

[Described from specimens Hopk. U, s. 11947 hand 11845t.]

This larva, so far as known, mines only under the bark of dead or dying Castanea and Quercus, constructing extensive meandering and crossing mines. The frass is packed behind the larva. The mines are often confused with those of Agrilus, from which they can be distinguished by the fact that Agrilus intermittently breaks the mine by going into the bark or outer laver of wood for very short distances, whereas Callidium always works between the bark and the wood, the mine being always plainly visible. It pupates in early spring, either in the bark or in the outer layers of the sapwood. The adults commonly emerge through April and May or June in the North. Fiske records it as hastening the death of diseased chestnuts in the South. Range, throughout the eastern United States and Canada.

\section{PHYMATODES VARIABILIS Fabricius}

\section{[Pl. XVIII]}

No genal setae; ocelli a black spot beneath chitin, not protuberant; last joint maxillary palpi little longer than second, equal to last labial; first and second joints of antennae subequal, little longer than thick; striae of pronotum coarse, irregular, merging into a granulate band behind; ampullae shining, coarsely granulatc, these granules flattened into tiny plates; faintly marked with a transverse and two lateral impressions; pleural dises distinct on first, second, third, fourth, fifth, and sixth abdominal segments; legs four-jointed; texture shining, granulate.

[Deseribed from specimens Hopk. L.... 11stig and 9793a.]

The larva mines chiefly in the bark of oak (Quercus) and is often of economic importance in the tan-bark industries. In thin bark it burrows between the bark and the wood, making a short curved pupal cell in the sapwood. It pupates in the early spring. A. D. Hopkins and $I V$. F. Fiske have both recorded it from Picea and Tsuga.

\section{PII YMATODES NITIDUS Leconte}

Genal bristles numerous, long; ocelli not distinct, a dark spot beneath chitin; last joint of maxillary palpi slightly longer than penultimate; first and second antennal joints short, little longer than thick, subequal; pronotum posteriorly marked with fine and regularly impressed striae; median suture impressed; ampullae finely granulate; pleural dises clistinet on first, second, and third scgments; legs three-jointerl.

[Described from specimens Hopk. U. s. 2348 and 11858b.]

Pupa: Unarmed except for several conical chitinous-tipped papillae on sixth abdominai tergum and four on seventh.

The larva mines beneath the bark of Cupressus, Seouoia. and Thuja. Pupation occurs in the sapwood or between bark and wood. Found in the Pacific Coast region. Collected by H. E. Burke and F. M. Trimble.

\section{GALLIDIUM IIIRTELLUM Leconte}

Genal bristles numerous and long; ocelli not distinet, a dark spot bencath chitin; last joint of maxillary palpi one and one-half times the length of second, shorter than last labial, basal joints transverse; second joint of antennae slightly longer than first, neither longer than thick; pronotum posteriorly bearing a few irregular markings, tending to be rugulose, median suture impressed; ampullae altaceous, with a deep median furrow; pleural dises distinet on first, second and third segments; legs indistinctly three-jointed.

[Described from specimens Hopk. U. s., 94ssc and 10074.]

The larva has been collected in the small dead twigs of Pinus ponderosa by A. D. Hopkins and J. M. Miller in California. 
PHIMATODES AMOENUS SAIY

[1'I. IX, XIX]

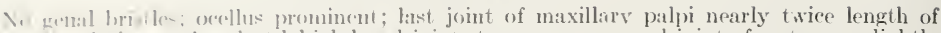

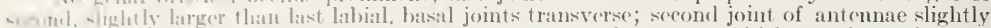

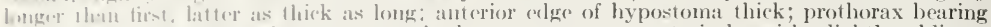

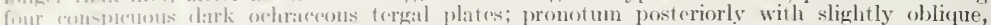
shaply mureserl striae, median suture impressed; ampullae alutaceousls sub-tubereulate, with at denp meslian furrow; pleural dise's distinct on second and third segments, fainter on first and fourth: legs llurer-jointerl.

l)escribed from specimens Hopk. […. 1222S

This species has been eollected in dead grapevines (Itis). The larval mines are extended principally through the wood and are tightly packed with frass. Pupation takes place very early in the spring. Range, eastern United siater and c'analat.

\section{PIIMATODES DIMIDIATUS Kirby}

Xo grenal bristles; ocelli prominent; last joint of maxillary palpi longer than second, equal (1) list labial, hasal joints transverse; second joint of antennae slightly longer than first, latter as llick as long; pronotum posteriorly bearing a few striae, median suture impressed; ampullae ahutaceusly granulate; pleural dises most distinet on second and third segments, faint on first, fourth, and fifth; legs four-jointed; spiracles nearly orbicular; very small, peritreme thin.

[Deseribed from speemens Hopk. L. S. 11835 and 12693a.]

The larva has been found in Picea, Tsuga and Larix. It mines beneath the bark, construeting a rather long prepupal mine in the wood. Range, throughout eastern Lnited states and Canada to the Rocky mountains.

\section{PH IMATODES VULNERATUS LeConte}

Vo genal bristles; ocelli very prominent, black pigmentation directly under protuberance; last joint of maxilllary palpi longer than second, slightly shorter than last labial; antennae slenter, second joint longer than first, first a little longer than wide; pronotum posteriorly strongly striate. II clian suture impressed; ampullae shining, alutaceously reticulated; pleural dises lirge and distinct on seeond and third segments, faint on first; legs four-jointed; spiracles nirrowly oval, about as long as ocellus, peritreme heavy. Integument tough, shining, densely hairel.

P'upa: Body glabrous, except for small chitinous-tipped papillae on abdominal terga, becoming stronger posteriorly and tending to form an oval grouping; lasi tergum bearing four small spines, two usually larger.

[Described from specimens Hopk. [. S. 14415d.]

Collected by F. B. Herbert at Placerville, Cal., in dead dry branches of Acer macrophyllum.

PIIMATODES VARIUS Fabricius

[Pl. XXXIII]

No genal bristles; ocellus large, prominent; last joint of maxillary palpi slightly longer than second, shorter than last labial; joints one and two of antennae subequal, slender; striae of pronotum short and slightly oblique, ending in a granulate area, median suture impressed; ampullae dull, very finely granulate; pleural dises distinct on first, second and third segments; legs threce-jointerl.

[Described from specimens Hopk. L. s. 10075p.]

The larvac work as those of Callidium aereum and usually are associated with it beneath the bark of white oaks (Quercus). It has been collected from Eastern ('anada to Arizona.

\section{PIIYMATODES DECUSSATUS LeConte}

This spceiss can not be distinguished from varius, except by the somewhat finer granulations of the ampullae.

Pupa: Lnarmed except for a few (about six) small, scarcely chitinous-tipped, tubereuliform points in a single row, on second to seventh abdominal terga.

[Deseribed from specimens Hopk. U. s. 1925.]

These linvae were collected by A. D. Hopkins and H. E. Burke beneath the bark of Quereus at Fima, Wash. 


\section{CALLIDIUM ANTENNATUM Newman}

\section{[Pl. X]}

Form robust, somewhat depressed; integument rather thick, more or less reticulated, shining, covered with long castancous hairs.

IIead rectangular, nearly as wide in front as behind; mouth-frame very heavily cornified, reddish brown to piceous, often much wrinkled; epistoma straight; labrum rather thick, transversely semicircular; mandibles longer than basal width, basal piece dark brown, two-thirds width of distal, latter shining, piceous; second antennal joint longest, first and last subequal, supplementary, minute, indistinct; ocellus large, yellow, widely enveloped by very large tuberculate genal shoulder. Ventral mouth-parts somewhat coriaceous, process of palpifer as long as last maxillary joint, joints of maxillary palpi successively shorter, last labial joint longer than last maxillary; anterior edge of hypostoma bearing four black, prominent, conical projections; subfossal spine distinet; gular sutures widely diverging behind.

Prothorax short, rectangular, pronotum one and one-half times as wide as long, anteriorly hairy, posteriorly sparsely irregularly striate to alutaceously reticulated, no mechian suture; sternum reticulated, shining, not differentiated into areas; sternellar fold rather strongly fused at extremities into epipleurum. Legs four-jointed, without tarsus about as long as maxillary palpi.

Abdomen: Dorsal ampullae alutaceous, shining, bounded by two lateral converging folds which are joined anteriorly by a transverse one, ventral with two deep lateral impressions; pleural dises visible on first, second, third, fourth, fifth and sixth seginents. Spiracles oval, large, peritreme castaneous, thin, but distinct.

Pupa: Form similar to that of adult, armed with very small, blunt, chitinous points, a few on posterior edge of pronotum, two small groups on mesonotum and metanotum, and on each abdominal tergum, growing fewer posteriorly. In some forms from Colorado these points are scarcely chitinized.

[Deseribed from speeimens Hopk. C. S. 11857.]

This species spends the greater part of the larval period boring between the bark and wood. The latter is deeply searred, but not entered until before pupation, when a long pupal cell is constructed parallel to the grain of the wood The frass loosely fills the burrows and much is expelled. The pupal cell is opened to the exterior by the larvae. One generation oceurs each rear. This insect often becomes of economic importance in rustic work. Specimens have been collected from Pinus and Picea, while other forms, probably distinct species, breed in Thuja, Juniperus and Chamaecyparis.

\section{GALLIDIUM FRIGIDUM Casey}

A few specimens which may be this species have the body covered with white hairs; the pronotum is more regularly and finely striate and the tubercles on hypostoma very small or inner pair nearly obsolete. This is also the case in some of the western forms of antennatum.

[Described from specimens Hopk. U.s. 11913b.]

Habits similar to those of antennatum though more confined to the northwestern United States and higher elevations.

\section{PHYSOGNEMUM ANDREAE Haldeman}

\section{[Pl. XXIX]}

Form elongate, depressed; integument rather dull, thick, alutaceous, sparsely covered with fine whitish hairs.

Ilead subtrapezoidal, widest behind; mouth-frame strongly corneous, reddish brown; labrum thick, fleshy, sub-rectangular; mandibles little longer than basal width, apical half about three times the length of basal, having a groove on outer face, entirely black, shining; one large ocellus contiguous with antennae, enveloped by genal shoukder; antennae long, slender, second joint longest, last very slender and tapering; gemal bristles short, stiff; last joint of maxillary palpi equal to second, shorter than last labial; lobe of palpifer large; gulat not very prominent, sutures diverging: no subfossal spine.

Prothorax rectangular, transverse; pronotum one-third wider than long, anteriorly finely rugose, hairy, posteriorly obliquely rugulose, striate, shining; lateral sutures entire, median faintly impressed; prosternum rugulose, shining; sternothar fold not passing beyond spiracles. Mesonotum and metanotum dull, alutaceous, with a trausverse impression; legs inclistinctly four-jointed.

Abdomen: Ampullae broad, flat, alutaceous, shining, dorsally marked by two lateral longitudinal folds and one transverse one connecting them anteriorly, ventrally marked by two lateral, deep triangular impressions and sixth and seventh laterally bounded by a series of 
Wuritulnat corncous curimas. Syiracular area and epipleurum projecting in prominent lobes; Whenat dises distmet on third, fourth and fifth segments; spiracles broadly oval, large, peritreme lim

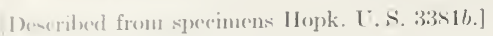

The latral mines resemble those of $/ /$. amethystinus, but often are still more extensive. Pmpation take place in the sapwood. The life eyele is completel in one rear. All specimens have been taken from Taxodium in the voutheastern linited states.

\section{PIIYSOGNEMUM BREVILINEUM Say}

Form and in general as in andreae, but differing in that the texture is smooth and shining, the spiracte and epipleurum less distinct, the pronotum without median sut ure and the striations finc and very regular, the genal bristles few and fine, and the lateral earina absent on sixth and serenth anpullace.

[Described from specimens Hopk. U.S. 9791z.]

The larval habits of this species are unusual in this tribe. It has only been taken mining in the outer bark of living Ulmus. The burrows are rather rxtensive and meandering, tightly packed with granular frass. Pupation occurs in a cell in the bark. Similar feeding-bark habits occur sporadically in several other genera in the Cerambycinae. Observations by A. B. Champlain and the author.

\section{GONOCALLUS COLLARIS Kirby}

[Pl. X]

Form eylindrie, rather robust; integument firm, rather glossy, white, densely covered with long castaneous hairs.

Head subquadrate, rather broad in front; mouth-frame corneous, dark chestnut brown; epistoma swollen and wrinkled; labrum thin, little wider than long; mandibles longer than wide at base, basal piece brown, distal piccous, shining, one and one-half times length of basal; antennae slender, second joint, slightly longest; ocellus large, white, enclosed by slightly shouldered gena, latter bearing three to four long bristles. Ventral mouth-parts slightly coriaceous, joints of maxillary palpi subequal, last shorter than last labial; subfossal spine distinct; gula narrow, sutures shightly diverging.

P'rothorax rectangular, thick, yellow tergal plates prominent; pronotum little wider than long, hairy, posteriorly irregularly striate, merging into finely granulate, median suture entirely impressed; sternum rugulose, reticulated. Mfesonotum and metanotum smooth. Legs fourjointed, without tarsus as long as maxillary palpi.

tbdomen: Dorsal ampullae finely granulate, dull, impressed by two lateral sutures, converging and meeting the transverse one. Pleural dise distinct on first, sceond and third abdominal segments. Sipiracles small, suborbicular, peritreme thin.

[Deseribed from specimens Hopk. T...'. 10385c and 12610a.]

The larva feeds in the stems of young pines and spruce (Pinus and Picea), boring beneath the bark and pupating in the wood, completing the life eycle in one vear.

\section{MERIUM PROTEUS Kirby}

$$
\text { [Pls. XV, XIX] }
$$

Form robust, cylindric; integument firm, rather dull, densely covered with long, light castaneous hairs.

Head transverse, rather broad in front; mouth-frame strongly chitinized, dark brown; labrum about one and one-half times as wide as long; mandibles longer than wide at base, basal piece reddish-brown, one-half as wide as distal piece, latter piceous, shining, with a faint longitudinal groove; first and second antennal joints subequal, last one-half as long as first; one large white ocellus contiguous with antennae, enclosed by shouldered gena; a few long genal bristles. Ventral mouth-parts slightly coriaceous, joints of maxillary palpi successively shorter, last slightly shorter than last labial; hypostomal edge often roughened; subfossular spine distinet; sutures diverging convex.

Prothorax rectangular, hairy; pronotum little wider than long, posteriorly substriate to granulate, no median suture; sternum undifferentiated, rugulose, hairy, except for two glabrous shining spots; sternellar fold not passing spiracle, rather broadly fused into epipleurum. Mesonotum and metanotum finely alutaceous, bearing a transverse impression. Legs short, fourjointed, without tarsus equal to maxillary palpi. 
Abdomen: Dorsal ampullae rather narrow, alutaceous, two oblique lateral impressions connected anteriorly by a transverse one, skin behind ventral ampullae transversely wrinkled. Pleural dises distinct on first, second and third abdominals, faint on fourth. Spiracles oval, small, the last orbicular, peritreme thin, ochraceous.

[Deseribed from sepeimens Hopk. Ĺ. S. No. 12652a.]

This species has been found only in Picea. The larva bores beneath the bark of dead trees, entering the wood to pupate, and completing the life cycle in one year. It causes much damage to rustic work in Maine and eastern Canada. It occurs from eastern Canada to the Rocky Mountains.

\section{XYLOCRIUS LeConte ${ }^{1}$}

Several larvae in the U.S. Forest Insect Collection belonging to the Callidini are quite similar to Merium and Callidium. They have never been reared or associated with adults, but by elimination have been placed in this genus until their position can be verified. They may be recognized as follows:

Integument tough, shining, densely covered with long, dark, castaneous hairs; head much depressed; gena broadly shouldered and tuberculate, enclosing distinct, protuberant ocellus and bearing several inconspicuous hairs; labrum small, roundly rectangular; last joint of maxillary palpi shortest, shorter than last labial; palpifer and first palp is joint bearing distinet process; gula indistinct; hypostoma smooth. Thorax and abdomen much as in C. antennatum; spiracles broadly oval, peritreme thin; pleural dises distinct on first three or four abdominal segments; seventh ventral ampulla lacks chitinous plates.

[Described from specimens Hopk. U .S. No. 11919.]

It has been collected in Colorado in Pinus flexilis by Geo. Hofer, A. B. Champlain and the author. The work resembles that of Callidium antennatum in the form of mine beneath the bark, the expulsion of frass from a small hole and the long pupal cell in the wood which is opened through the bark by the larva. It attacks dying trees, probably hastening the death of the branches.

\section{Tribe CLYTINI}

The following larvae form a natural group of several disinet genera; they may be recognized as follows:

Form robust, contracted, rather thick, tapering to last few segments, then suddenty swelling. IIead trapezoidal, widest behind; ocelli small, one to three; gena never shouldered; no genal setae; labrum never longer than wide; thick; mandible without sulcus or groove on outer face; subfossal spine wanting or very ininute; process of palpifer minute or wanting; last joint of maxillary palpi relatively short. Prothorax thick, having distinet proalar plates and short, more or less subulate hairs on the lateral region; pronotum posteriorly raised, projecting forward along the median line, glabrous or velvety pubescent, never striate; median suture absent or impressed; eusternum never distinct but region marked by two round, glabrous, shining spots; ventrolateral sutures a short notch; sternellar fold disinet at extremities, passing beyond spiracles; mesonotum bearing the posterior half of an $\mathrm{x}$-shaped impression (scutellum distinet); metanotun with one transverse impression; legs wanting, one, two or three jointed, femur plus tibia never as long as maxillary palpus. Ampullae broad, oval, flat, the dorsal and rentral surfaees parallel, bearing two lateral and a transverse inpression, though often indisclinci; pleural dises not distinct nor granulate, usually a half dise of wrinkled texture; the other half obliteraterl by a tubercle-like swelling.

The general tendency of these larvae is to be wood-borers, spending a proportionately shorter time between the bark and wood and a greater length of time in the wood proper. A striking correlation between habits and strueture is well illustrated within the species. The species of Cyllene normally spend about half the larval growth between the wood and bark, several not entering it before constructing the pupal cells, but deeply scoring the wood (as those of Arhopalus and Cyllene pictus); others enter carlier and mine in the wood considerably (as those of $C$. antennatus and $C$.robiniae). C. robiniae attacks living trees and the body hairs have become short and rather stiff. The species of Neoclytus are typical wood-feeders, often completely honeyeombing the wood in which they are boring, the extreme cases illustrated by $N$. capraea and $N$.

${ }^{\text {Since }}$ writing this deseription the adult was reared. It was described by W. S. Fisher as Elatolrypes ho $i$. Pro Ento. Soc., Wash. Vol. 21, p. 38, 1919.

$57951-4$ 
contisnctus. In intermediate position is that occupied by most species of Vifuluchus, thomeh a fow also illustrate the extremes. All the species of Nendylus lack the velvety pubesernee of the pronotmm and ampullae, as do two species of Tylotrechus, both of which are typical wood-borers. (On the lemaining species of Sylotrechus the ampullac are clothed with velvety pulescence, though to a varying degree; in some forms only the perimeter is puluesent, in others the "ntire surface (c.g. Nylotrechus obliteratus, which bores in the softer moist wood of Populus and Salix). Two species of Xylotrechus (aceris and ynadrimaculatus) attack living trees. In both of these the velvety pubesence has become much coarser and stiffer or velvety asperate. In one (yuadrimaculatus), which girdles branches mining in the living wood until the branch is dead, the perimeter only of the ampullae is pubescent; in the other (aceris), which occurs in the trunk of living trees, the ampullae are contirely covered.

\section{KEY TO THE GENERA OF CLYTINI}

Ocolli normally three; no median pronotal suture; legs three-jointed.............. Cyllenes Oerlli one.

Iechian suture of pronotum not impressed.

Legs at least two-jointed: neither pronotum nor ampullae velvety pubescent; subfossal

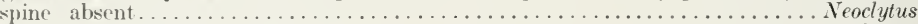

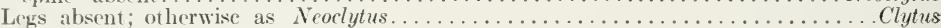

Median suture impressed.

Legs absent or minute spines.

Posterior area of pronotum and ampullae usually velvety pubescent; pronotum never striate, subfossal spine present, very small...................

Posterior area of pronotum striate, neither it nor ampullae velvety pubescent, latter dull, granulate; subfossal spine absent; legs minute spines................. Clytanthus

Legs at least two-jointed; pronotum striate; ampullae shining, sub-tuberculate; subfossal spine absent; breeds in Vitis................................. Clytoleptus

\section{Group GYLLENES}

The following genera Plagionotus, Arhapalus, Calloides, and Cyllene, cannot be recognized in the larval stage. They are here considered to form a natural genus. They can be recognized as follows:

Legs three-jointed, femur plus tibia much shorter than maxillary palpi; three ocelli normally present, sometimes fused into two or one; process of palpifer minute; posterior area of pronotum shining, never pubescent, no median suture; ventro-lateral suture a short noteh; sternellar fold distinet, extremities passing spiracles; ampullae granulate or alutaceous; form robust, eontracterk.

All these larvac lave several habits in common. They mine beneath the bark rather deeply seoring the woor until nearly two-thirds grown, when they enter the wood. During the larval growth much of the frass is exuded through an opening (marking the point where the egg was faitl) that is enlargect as the larva grows, so that when the larva is ready to pupate this hole is large enough to permit the escape of the adult. The pupal cell, deep in the wood, is plugged far from the exit hole by one wad of fibrous frass. The pupa always faces toward this exit.

\section{KEY TO THE SPECIES OF THE GROLP CYLLENES}

No process of palpifer present; ampullae dull, finely granulate, breeds in maple (Acer)

Process of palpifer minute but distinet; ampullae variable.

Ampullac alutaceous, rather shining.

Intcgument, tough, dull, breeds in Quercus at surface of ground.......Calloides nobilis

Integument thin, shining; breeds in trunks of Quercus and Castanea... Arhopalus fulminans

Ampullae dull, finely granulated.

Posterior edge of pronotum finely velvety pubeseent; spiracles narrowly oval, body hairs silky; breeds in Hicoria (rarely in Celtis, Fraximus, Toxylon, and Vitis)

I'osterior elge of pronotim not vituene pictus pubescent; spiracles narrowly oval; body hairs

Posterior edge of pronotum velvety p............................... antennatus hairs coarser, light castaneous; breeds in Robinia................ Cyllene robiniae 


\section{CALLOIDES NOBILIS Say}

\section{[Pl. X]}

Form robust, tapering posteriorly to last few segments; integument tough, rather dull, hairs coarse, short, dark castaneous.

Head distinctly trapezoidal, narrowing in front; mouth-frame strongly corneous, dark ; clypeus and labrum thick, fleshy, latter shortly stalked, sub-orbicular, densely ciliate on perimeter; mandibles tapering, narrow at apex, dull black basal piece about one-half length of apical, no fovea on outer face; first antennal joint slightly shorter than second, about equal to third, supplementary distinct; ocelli, three, indistinct or fused unto one or two, set in a slight genal impression; gena not shouldered. Ventral mouth-parts rather coriaceous; palpal joints acute, last labial and last and second maxillary all subequal; process of palpifer minute though distinct; no subfossal spine.

Prothorax thick, about twice as wide as long, four tergal plates distinct, lateral region densely clothed with short, subulate, dark castaneous hairs except for numerous glabrous spots; pronotum coarsely punctured, posterior area reticulately rugose, embossed and extending anteriorly along median line, no median suture; sternum having two glabrous chitinous spots; ventrolateral suture a short notch. Mesonotum bearing a v-shaped impression (scutellum distinct), metanotum with one transverse impression, both alutaceously granulate. Legs short, conical, of two transverse joints and a short, conical, chitinous tarsus.

Abdomen slightly compressed; ampullae large, broadly oval, abruptly raised, alutaceously granulate, dorsal bearing two short lateral and one transverse impression. Pleural dises indistinct. Spiracles broadly oval, dark reddish-brown, peritreme thin.

Pupa: Lateral margins of pronotal disc spinulose; mesonotum and metanotum glabrous; eight abdominal terga bearing short, acute, chitinous papillae, on first six segments, these extending posteriorly, last two recurved.

[Described from specimens Hopk. U. S. 11851.]

The larva has been found only in the base of recently cut or dying Quercus stumps and bases of trees. It requires considerable moisture and a great proportion of the mine is extended beneath the ground along the surface of the roots, between the bark and wood. The full-grown larva construets a long prepupal burrow sometimes 12 inches in length deep through the heartwood. If this is constructed in a stump it opens near the centre on the eut surface; if in a tree, it is turned obliquely out to the bark and never penetrates so deeply into the heartwoor. This hole is left open to the exterior by the larva, giving the appearance that the adults had emerged. Most of the brood transform in one year, though some remain over the second year. This is a more northern species in eastern and central United States and Canada. Observations by the author.

\section{ARHOPALUS FULMINANS Fabricius}

\section{Pl. XLII}

Form less robust than that of Calloides nobilis; integument thin, shining, hairs on abdomen fine, of a dark lemon colour.

Head in general as in Calloides, mouth-frame less chitinized, light reddish brown; labrum transversely oval. widest behind, covered with long silky hairs, except for glabrous spot in "c ntre, process of palpifer distinct; process on first joint of maxillary palpi distinct, last joint of maxillary palpi shorter than second, and shorter than last labial.

Prothorax having hairs of proalar and lateral regions shorter, denser, and finer than in Calloides, light castaneous; pronotum posteriorly shining with a few elongate punctures to short fovea. Spine of legs not strongly chitinized.

Abdomen: Ampullae dull, finely alutaceous. Spiracles narrowly oval, dark lemon colored, peritreme thin.

Pupa: Pronotum regularly beset with slender, straight, acute points, longer on sides and less numerous on dise; metanotum bearing two oblique rows of short bristles; each abdominal tergum armed with two transverse rows of slender acute spines projecting backward, except those on hind border of the seventh and eighth segments, which are longer and recurved.

[Deseribed from specimens Hopk. L.... 118:32.]

The larva bores beneath the bark, deeply seoring the wood until half grown, when the sapwood is entered from 4 to 6 inches. Not so much frass is extruded as by the species of Cyllene. The most striking feature of the work is the pupal cell, construeted at the end of the prepupal gallery, which is suddenly turned at an angle of from 40 to 45 degrees, cutting across the grain of the wood. Observations by the author. It has been eollected in Quercus and Castanea throughout the eastern United sitates.

$57951-4 \frac{1}{2}$ 


\section{PI.IGIONOTUS SPECIOSUS Say}

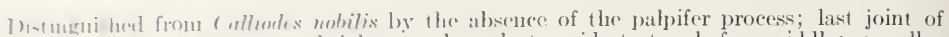

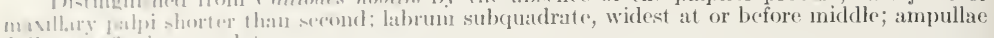
hull, wis fincty gramulate.

1), colved from sperinens in the collection of (i. Dimmock.]

The habits of this specens have been adequately diseussed in literature. It attacke living had maples $(A \mathrm{cer})$. The larvae during the first year mine boneath the bark, often girelling the branch and eausing its death. The second year a decp bureow is made obliquely up and into the heartwood at the end of which the larva pupates. Two yours are required to complete the development. This species oecurs throughout the northeastern section of the United States and canala, and has leen found in West Virginia by A. D. Hopkins.

\section{GYLLENE PICTUS Drury}

\section{[Pls, XV, XVIII, XX, XXVI]}

Frmm robust, contracted, laterally compressed to last few segments; integument dull, liair's dense, fine, silky, lemon-coloured.

Ilead subtrapezoidal; mouth-frame heavily corneous; epistoma thick, abruptly raised, deeply enarginate at centre; labrum orbicular, fleshy, fincly ciliate; mandibles tapering, narrow at apex, dull, not grooved on outer face; first antennal joint slightly shorter than second, third small; ocelli distinct; last joint of labial palpi and of second and third maxillary subequal; process of palpifer minute, distinet.

Prothorax transwerse, short, and thick, densely covered with short fine hairs on sternal, alar and lateral regions; prothorax with four distinct ochraceous tergal plates; pronotum posteriorly very finely rugulose, striate to finely granulate, a band of dark velvety pubescence on posterior margin of pronotum and etsternal region. Legs consisting of two transverse joints and al short chitinous spine.

Abdomen laterally compressed, dorsal and ventral surfaces flat, parallel; ampullae large, prominent, oval, white, dull, very finely granulate having the impressions faint. Spiracles narrowly oval to oval. Otherwise as in Calloides nobilis.

Pupa: Disc of pronotum armed with many short, not sharply acute, chitinous points; a few on mesonotum and metanotum; more acute ones on each abdominal tergum, those on s'venth and eighth very strongly chitinized, long, acuminate, and strongly recurved; usually twelve on seventh tergum and four on eighth.

[Described from specimens Hopk. [T.S. 945za.]

This species is of economic importance and has been discussed in literature. Pupation oceurs in the fall, the adults emerging in the early spring. A remarkable uniformity in the transformation to pupa is shown. All larvae transform at nearly the same time, and during the winter it is impossible to find a single larva unless it be a deformed or injured specimen, and even this is rare. It normally foeds in IIicoria and often in Toxylon and has been found in Pennsylrania in Fraxinus by A. B. Champlain and in Celtis and Vitis by E. M. Craighoud and J. N. Knull. A. D. Hopkins records it from Gleditsia and possibly from Morus, in West Virginia.

\section{CYLLENE ROBINIAE Forster}

Fasily distinguished from pictus by the broadly oval to orbicular spiracles; the abdominal hairs are coarser; the posterior edge of the pronotum and pro-eusternum are velvety pubescent.

Pupa: Armature stronger, but otherwise similar to C. pictus, except that the metanotum has fewer spines and the abdominal segments, especially the hind margin of the last two, more numcrous spines.

Described from specimens Hopk. [. S. 6062.]

This species is of considerable economic importance, doing great damagc to living black loeust (Robinia pseudacacia), especially in plantations. The character of the work is similar to that of other species; the life cycle is completer in one year, adults emerging in the early fall Extensive biological clata have been collected and published. 


\title{
GYLLENE ANTENNATUS White
}

More robust and larger than pictus; the body hairs are long, silky, white to yelıwish white, even those on the lateral region of the prothorax being deeidedly more slender. The posterior edge of the pronotum and pro-eusternum does not have the velvety pubesenee; spiraeles narrowly oval.

[Described from speeimens Hopk. U.S. 12646 and 12645.]

This is a southwestern species similar in habits to $C$. pictus. Its favoured host plant is Prosopis, but it has been recorded also from Acacia. Observations by W. F. Fiske, J. L. Webb, and M. Chrisman.

\section{NEOCLYTUS Thomson}

This genus can be distinguished from Nylotrechus by the presence of minute legs of at least two joints; posterior area of pronotum never finely pubesecnt, but usually elear white, dull, finely granulate; no median suture impressed; ampullae dull, finely granulate and never bordered by velvety pubescence; no subfossal spine.

The species are very uniform in habits; all, so far as known, mine beneath the bark for a very short time, then penetrate the sapwood and heartwood, completely honeycombing them. The mines are very extensive and tightly packed with granular frass. The larvae attack both coniferous and hardwood trees. Most species complete the life cycle in one vear. Usually by early fall all species have pupated and transformed to adults, emerging during the first warm days of spring.

\section{KEY TO THE SPECIES OF NEOCLYTLS}

Last joint of maxillary palpi about equal in length to seeond.

Anterior edge of hypostoma thick, swollen and somewhat projeeting forward at sides of gula. Band of dull granulation on posterior border of pro-eusternum biseeted in middle by longitudinal band of hairs.

Breeds in Fraxinus. . .

Breeds in Quercus.

Band of granulation continuous

N. capraea

V. conjunctus

I. scutellaris

Band of granulation of posterior border of pro-ensternum bisected by longitudinal band of

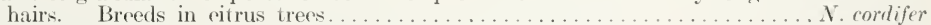

Band continuous. Breeds in Iticoria.

Last joint of maxillary palpi much longer than second.

second joint of antennae slender, longer than first ...

First and seeond joints of antennae subequal, about as long as thick.

Oeellus large. Breeds in Pinus

Oeellus minute. Breeds in Quercus.

i. luscus

N. erythrocephalus

N. muricatulus ........ longipes

\section{NEOCLYTUS GAPRAEA Say}

\author{
[Pls. I, X, XXYV.]
}

Form robust, short, eontraeted, tapering to last few segments, then dilated; integument firm, rather dull, rather densely eovered with fine lemon-whice, silky hairs.

Head trapezoidal, widest behind mouth-frame, strongly corneous ancl much thiekened; labrum thiek, subeonvex, orbieular, hairs few and rather long; mandibles short, piceous, shining, narrowed at apex, rather abruptly eonstrieted on outer faec above basal piece; first and seeond antennal joints subequal, third shorter; oeellus one, distinet, eontiguous with base of antennae; gena neither shouldered nor setose; pleurostoma and anterior edge of lyypostoma very thick, swollen and somewhat protuberant; ventralmouth-parts rather strongly coriacious, joints of maxillary palpi subequal, basal transverse, last shorter than last labial; proess of palpifer minute.

Prothorax thiek, trapezoidal; posterior pronotum dull, smooth and fincly reticulated and alutaceous to finety granulate on posterior edge; sternum finely granulate, dull along posterior margin, but divided by median hand of hairs. Legs minute, eonsisting of a single joint and a soft spine.

Ampullae broad, flat, oval, dorsal and ventral surfaees straight and parallel, dull, finely granulate, not distinctly marked except by a few lentieular inpressions. Pleural clises not distinct. Spiraeles narrowly oval, peritreme not thick.

Pupa: Unarmed except on second to seventh abdominal terga which bear minute chitinous points, beeoming more numerous, larger, and more acute posteriorly.

[Deseribed from speeimens Hopk. U. s. $9091 a$ and 10341 $a$.] 
This suenes illustrates the extreme in the wool-boring activity in this genus It mmes very little maler the batk and completely honeycomb the sapwood atud onter heattwoul. The mines are tightly packed with granular frass. One grencution ocents catch year. It often becomes of considerable ceonomic importanes. It has been collected throughout the United states and eastern ('antulis in Frarimus. II. F. Fiske and M. ('hrisman reeord it from Prosopis and ()uress in Irizona and A. B. Champlain from Quercus in Colorado.

('lerill larvare of the genus ('hariessa frequently prey on this larva.

\section{NEOCI, YTUS CONJUNCTUS LeConte}

This larva ean searcely be separated from that of capraea exeept in the nearly matured form, wher the anterior eilges of the hypostoma are not greatly swollen. The spiracles are smaller (midette abdominal ones searcely larger than ocellus) and more narrowly oval.

P'up: Irmed on the first seven abdominal terga with surall fleshy papillae, which are chitimons-tipped, these being from 15 to 20 in number while capraea has about 40 on some segmonts.

[Described from speemens Hopk. C. S. 9016 and 9592.]

Habits similar to those of capraca. It is a common species from the Rocky Mountain region west, breeding in Fraxinus, Quercus, Arbutus, and Pyrus.

\section{NEOCLYTUS SCUTELLARIS OIIV}

Form more slender than in capraca; hairs light eastaneous, sparse. Pleurostoma and anterior edge of hypostoma swollen and heavily eorneous to the same degree as in conjunctus, somewhat bisinuous: second joint of antennae longest, first about as long as thiek; last labial joint shorter, second equial to last labial. Posterior area of pro-eusternum having a dull, transverse, finely granulated band; mesosternum and metasternum also dull ganulate. Spiraeles small, oval, midclle abelominal ones seareely larger than ocellus. Otherwise as cafraea.

[Deseribed from specimens Hopk. U. S. 12604.]

This larva has only been found in Quercus alba, always associated with a dry fungus rot. It works similarly to sapraea, but the mines are not so extensive, Range, eastern United States.

\section{NEOCLYTUS CORDIFER Kilug}

[PI. XIX]

In general as in erythrocephalus; posterior transverse border of prosternum very narrow and bisected in midclle by longitudinal band of short stiff hairs; body more densely hairy, these liairs eastaneols. Joints of palpi subequal, seeond joint of antennae longer than first or third.

Pupa: Abdominal terga beset with fine chitinous asperites and a few short reeurved hooks not disposed transversely, very large on seventh segment. Hind and middle femora with two long conical processes at tibial articulation.

[Deseribed from speeimens Hopk. U.S. 9902i.]

These specimens were sent in by a correspondent who stated that they were killing the branches of pomegranate trees (Punica granatum) at Chase, Fla. Dr. F. A. Achwarz states that this species has been introduced from Cuba, where it is very destructive to orange (Citrus), pomegranate, and mango (Mangif ra indica) trees.

\section{NEOCLYTUS LUSCUS Fabrieius}

Form and body eharaeters similar to those of erythrocephalus; seeond joint of antennae longer than third; palpal joints subequal; posterior band of granulation on proeusternum continuous; body eovered with light eastaneous hairs.

Pupa. Prothorax with numerous small ehitinous points; spines on abdominal terga as in longipes; short conical points on middle and hind femora.

[Deseribed from specimens Hopk. U.S. 11840, 11830c.]

This larva attacks dying or dead Hicoria, mining about as much beneath the bark as in the wood. It is often associated with Scolytus-killed trees. liange, eastern ['nited states. 


\section{NEOCLYTUS ER YTHROCEPHALUS Fabricius}

A more slender species, sparsely covered with long whitish hair; last joint of maxillary palpi much longer than second; second and third joints of antennae subequal, slender; anterior edges of hypostoma normal. Posterior area of pronotum dull, finely granulate; ampullae dull more coarsely granulate; ochraceous tergal plates more distinct and narrowly transverse in this species; posterior border of pro-eusternum dull, finely granulate.

Pupa: Pronotum bearing a fleshy median tubercle on the anterior margin, no spines; in an irregular transverse row each abdominal tergum bears from 12 to 20 minute chitinous spines, increasing on posterior segments; seventh bearing 6 to 10 larger spines on fleshy bases.

[Described from specimens Hopk. U.S. 9782g.]

The larva feeds in a great variety of hardwood trees, working in the same manner as $N$. capraea. It sometimes becomes very destructive to round timbers in the woods, especially in the south, where several generations occur each year. It has been collected throughout the eastern and central United States from Hicoria, Fraxinus, Quercus, Juglans, Betula, Fagus, Ostrya, Acer, Celtis, Vitis, Cormus, Cercocarpus, Ilex, Prosopis, Cercis, Diospyros, Syringa, Gleditsia, Lonicera, Prunus, Sassafras, Robinia, Liriodendron, and Castanea.

A. D. Hopkins records it from Pinus and IV. F. Fiske from Taxodium, but these records are questionable.

\section{NEOCLYTUS MURICATULUS Kirby}

Form and in general as in erythrocephalus; sparsely clothed with yellowish hairs; last joints of habial and maxillary palpi subequal, latter much longer than second; first and second antennal joints subequal, about as long as thick; ocellus large, larger than abdominal spiracles; anterior edge of hypostoma not swollen; labrum transversely oval, sparsely haired; posterior granulation of pro-eusternum continuous.

[Described from specimens Hopk. U.S. 12695.]

This is the only species of the genus which has been found living in coniferous trees. It completely riddles the small branches of Picea, Larix, Pseudotsuga, and Pinus. Range, conforming to that of the spruces.

\section{NEOCLY'TUS LONGIPES Kirby}

Very similar to erythrocephalus; antennal joints subequal, first and second globose, seareely longer than thick; palpal joints relatively more robust, but last joint of maxillary palpi longer than second; ocellus minute or indistinet.

Pupa: Distinguished by the fact that the spines on abdominal terga are arranged in a single transverse row, or the last bearing a double row of small recurved hooks, each set on a fleshy conical papilla; protergum with scattered distinet spines on dise.

[Desioribed from specimens Hopk. U. S. 9765.]

The larva feeds in small dry oak (Quercus) saplings. forms to adult in the carly fall, hibernating in the cell.

It pupates and trans-

\section{CLYTUS MARGINICOLLIS Laporte.} hairs.

Form contracted, subeylindric; integument firm, shining, clothed with fine yellowish-red

Mouth-frame greenish-yellow; labrum roundly oval, shightly wider than long; mandibles short, robust, basal piece reddish, about one-half length of distal, latter having no foveae; first antennal joint transverse, second longest, third shorfest; ocellus distinet, contiguous with base of antennae; gena neither shouldered nor setose. Ventral mouth-parts fleshy; joints of maxillary palpi subequal, basal transverse, second about as long as wide; process of pahpifer about equal to last maxillary joint; gula distinet; anterior portion of hypostomal plates swollen and wrinkled.

Prothorax having four distinet tergal plates, alar and lateral areas sparsely haired; pronotum posteriorly shining and irregularly wrinkled; custernal spots glabrous, shining. IIesonotum and metanotum dull, finely granulate. Legs absent.

Ampullae faintly shining, finely granulate, having only lateral impressions; pleural dises indistinet; abdominal spiracles broadly oval to suborbicular, a little larger than the ocellus, peritreme thin.

Pupa: Short, erect, chitinous points on anterior margin and perimeter of pronotum; irregularly dispersed over abdominal terga, becoming larger and more numerous posteriorly and form1ing a row on hind margin of the seventh and eighth, these points recurved.

[Deseribed from specimens Hopk. [.S. 11890.] 
These larvare were reared from egge laid by the adults from May 6 to 15 ,

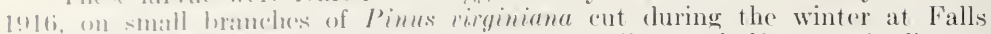
(hmel, lit. The larvase bere beneath the bark until about half grown, feeding on louth hark and wool; later, antering the woot, they extend a long burrow, at the omel of which the pupal cell is constructed. Pupation oceurred in september. 1) herrations he J. N. Limull and the author.

The larva in many respects resembles that of Neoclytus.

\section{XYLOTRECHUS Chev.}

These larvae are recognized as being legless (one species possessing a minute spine); the hend batr's one ocedlus; process of palifer very small; posterior area of pronotum usually velvety pubesecht, as also the perimeter of the ampullae; median suture of pronotum impressed behind; rentro-lateral sutures a mere noteh; sternellar fold distinci at extremities, passing spiracles; form robust, contracesed.

1 varioty of habits are represented in this genus, but common to all is that of boring a great deal in the wood proper. In nearly all species over half the larval life is spent in the wood. A few species attack living trees, one girdling hranches, another mining the trunks of small trees. The remainder feed only in lead wood. All tightly pack the granular frass behind them. The position of the pupa in its coll varies in the different species, but the adult always gnaws its way through the bark. The life cycle is completed normally in one year.

\section{KLY TO THE SPECIES MYLOTRECHL 'S}

l'osterior area of pronocum not velvety pubescent; ampullae noi surrounded by velvety pubescencece

Liabrum suborbicular; legs usually a minute spine; breeds in Crataegus; eastern... Y. convergens Labrum distinctly wider than long; legless; breeds in Quercus and Eucalyptus; western

X. nauticus

Posterior area of pronotum and border of ampullae velvety pubescent;

Pronotal and ampullar areas covered with velvecy pubescence; hairs on lateral region of prothorax short but not stiff.

spiracles smaller, oval to orbicular.

Lase joint of maxillary palpus nearly globular, shorter than second. Breeds in Tsuga

Lase joine of maxillary palpus more slender, longer than second.

Breeds in hardwoods.

Breeds in coniferous woods

()elli about size of basal joini of maxillary palpi.

()erelli smaller.

spircales large, twice or more as long as wide.

Ampullae entirely covered with velvety pubescence.

I. fuscus

I. colonus

I. undulatus

I. sagittatus

Ampullae velvety pubescent only on perimeter and median stripe.

I. oblitcratus

X. sp 10359 X. insignis

Pronotal and ampullar area covered with asparate velvety pubescence; hairs on lateral region of prothorax stiff, subulate.

Ampullae not entirely pubescent; girdles branches of Almus, Fagus, and Betula. .

Ampullae entirely covered with pubescence; breeds in small living trees of Accr.. $\mathbf{A}$. aceris

\section{YLOTRECHUS CONVERGENS LeConte}

Readily distinguishable from all other species by the fact that the posterior area of the pronotum does not bear the velvety pubescence, but is dull and faintly reticulately rugulose or finely granulate (resembling Neoclytus); legs usually developed as a minute spine. Maxillary palpal joints subequal in length; first and second joints of antennae subequal, third shorter; labrum sub-orbicular; spiracles very broadly oval, peritreme thin; body hairs light castaneous.

Pupa: Very minuie, scattered, setiferous points on pronotum; mesonotum and metanotum unarmed; first six abdominal terga bearing small, acuminate, curved spines projecting posteriorly, becoming more numerous caudally; seventh bearing four larger recurved spines on posterior border and smaller ones on disc; eighth bearing two.

[Described from specimens Hopk. L.S. $9792 c$.]

The larva has been found only in the dead wood of Crataegus. It mines deep into the heartwood, completely honeycombing it. Pupation occurs in the late spring. Range, throughout eastern United States. Observations by the author. 


\title{
XYLOTRECHUS NAUTICUS Mannerheim
}

Similar to convergens, but legs wanting; labrum distinetly wider than long; first joint of antennae globular, equal to last, very much shorter than second.

[Deseribed from specimens Hopk. L'. S. 1315sa, and 13168a.]

The larval habits are likewise similar to those of convergens. It is a true wood-borer; collected from Quercus and Eucalyptus in California by F. B. Herbert.

\section{XYLOTRECHUS COLONUS Fabricius}

\author{
[Pls, XVIII, XX]
}

Form semirobust, contracted, subeylindric, tapering to last few abdominal segments; integument, firm, rather dull, densely eovered with fine, soft, lemon-eoloured hairs.

Head trapezoidal, gradually tapering anteriorly; mouth-frame corneous, very finely wrinkled, reddish-brown; labrum raiher thiek, soft, suborbieular, widest behind middle, with very short hairs; mandibles dull black, short, tapering rapidly to apex, basal piece about one-third length of apical, no fovea on outer face; first antennal joint about equal to lasi, much shorter than second, supplementary distinct; one distinct oeellus eontiguous with base of antennae; gena tapering, not shouldered, bearing several very fine hairs. Ventral mouth-parts raiher fleshy; all joints of labial and maxillary palpi subequal, basal joinis of latter transverse; process of palpifer short, distinet, subfossal spine small.

Prothorax reetangular, about twice as wide as long, thiek; four distinct oehraeeous tergal plates; lateral regions thickly beset with short orange hairs, those on sternum longer except for the large, suborbieular, glabrous eusternal spots; pronotum wider than long; median suture slightly impressed punctured and sparsely hairy anteriorly, posteriorly eovered with darkoehraeeous, velvety pubescenee and a posterior band on pro-eusternuin; mescnotum, metanotum and anterior half of sterna also covered with velvety pubescenee; ventral-latero sutures a mere noteh. Legless.

Abdomen: ampullae large, iransverse, flat, dull, very finely granulate, surrounded by velvety pubeseenee; ventral bearing a longitudinal median stripe, of velvety pubeseence, no distinct impressions. Pleural dise indistinet. Spiracles narrowly oval to broadly oval, periireme thin.

The larva feeds in almost all of the eastern hardwood trees. It is chiefly a bark feeder, mining between the bark and wood, rarely scoring the latter, and if the bark is thick it mines entirely in it. The life eycle is often completed from spring to early fall, or it extends over to the following season. Pupation may take place in either the bark or the sapwood.

\section{XYLOTRECHUS (ANNOSUS) FUSCUS Kirby.}

Pronotum posteriorly velvety pubescent, as are also the borders and often a median longitudinal band of the ampullae; antennae rather thick, sceond joint not twiee as long as thick, first globular, last more than half as long as second; labrum orbieular; last joint of maxillary palpi shorter than second; abdominal spiracles narrowly oval, first and last broadly oval, peritreme light orange coloured; body hairs very light castaneous.

[Deseribed from speeimens Hopk. L. S. 10081t and 9792

The larva feeds between the bark and wood, entering the latter when about half grown, where extensive mines are exeavated. The same tree is usually attacked from shortly after it has fallen until well decayed. As the wood becomes softer the larvae bore deeper. It has been collected from . Ibies and Tsuga. Range, in eastern United States and C'anada.

\section{XYLOTRECHUS SAGITTATUS Germar.}

Distinguishable from annosus by the subequal palpal joints; last joint of antennae one-half length of seeond and seeond scarcely twice as long as thick, basal globular; ocellus very small, spiraeles not so darkly rimmed; labrum broad on anterior margin, suborbieular; body hairs lighter.

[Deseribed from specimens Hopk. U.S. 12266 and a specimen, Craig. 241b, eollected at State College, Pa.]

Habits similar to those of undulatus but more eommonly found in Pinus Recorded also from Picea and Abies. Range, from Rocky Mountains east. 


\section{XYIOTRECHUS UNDULATUS Say}

I'muntum posteriorly velvety pubeseent, this dirker than in inost speeies, and often reduced t1 : 11:1row border, nom-puluserent portion white, ruglose; ampullae bordered with velvety

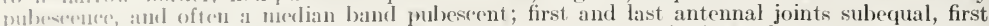
gumblrate, second nuch longer, ahout twice as long as thick; palpi joints subequal; oeellus large; labrun transversely oval; spiracles very smath, middle aldominat ones scarcely larger than ocedlus, peritrene thin; body hairs light eastaneous.

Described from specimens Hopk. U. S. 9522a, 12693b, 12652b, 11923a and 12682. Specinecus: 9.5:2 111 ay be different from the others.]

Habits similar to amnosus but it prefers more solid wood. A suitable place of attack is old fire scars or axe wounds where the larvae can gain entrance to the heirtwood. It has been collected in Pseudotsuga, Tsuga, Abies, Pinus and l'icen. Ranges throngh Rocky Mountain region and west.

\section{XYLOTRECHUS sp. 10359}

form sinilar to undulatus, but easily recognized by the ampullae being entirely velvety pubescent; spiractes large, very narrowly oval and conspicuously reddish brown in colour, peritreme thick; labrum orbicular, or rarely a little wider at middle; antennae more slender; palpi joints subequal.

Pupa: Margin of pronotum regularly beset with ereet chitinous points; each abdominal tergum armed with longer ones, eurved posteriorly, except on seventh and eighth, which are recurved, the eighth bearing four points smaller than those on seventh.

[Described from specimens Hopk. U. S. 10359, 10075w, and 11786.]

This species has been collected only in the dead or dying wood of Populus and Salix. It mines extensively in the heartwood. Range, through Rocky Mountain region west and in Canada. Observations by H. E. Burke, J. Brunner, N. Criddle, and the author.

\section{XYLOTRECHUS OBLITERATUS LeConte}

This speeies can be distinguished from the preceding only by the smaller and lighter coloured spiracle, which is searcely as wide as the ocellus; and by the finer pubescence of the ampullae, which cannot be distinguished individually with $\mathrm{a}^{\circ}$ objective and No. 4 eyepiece, as in the preceding.

[I)ereribed from speeimens Hopk. L. S. 10982d.]

These larvae have been collected only in the base of living aspen (Populus tremuloides) at elevations above 8,500 feet in the Rocky Mountains. The larvae mine the heartwood of the base and roots, often causing the trees to break off in great numbers. Observations of G. Hofer and the author.

\section{YLOTRECHUS INSIGNIS LeConte}

[Pl. XV]

This species has the large elongate abdominal spiracles simitar to the preceding, but the abdominal ampullae are covered with velvety pubescence only on the perimeter and a median stripe; the ocellus is small and the last joint of the maxillary palpi is slender, longer than the second.

[Described from speeimens Hopk. U. s.. 1316a'2.]

These larvae were collected by F. B. Herbert in Berkeley, Cal., in the wood of a dying willow (Salix lasiandra).

\section{XYLOTRECHUS ACERIS Fisher}

\section{[Pl. $\mathrm{XV}$}

Posterior pronotum and entire ampullae covered with asperate velvety pubescence, this very dark on pronotum; hairs on lateral region of pronotum stiff, subulate, dark castaneous; joints of maxillary palpi subequal or last slightly longer than second; second and last antennal joints subequal, first transverse, second about as long as thick; labrum suborbicular; spiracles narrowly oval, peritreme thick, dark castaneous.

Pupa: Anterior half and sides of pronotum armed with short, acute, chitinous points ; those on abdominal terga becoming larger and more slender to seventh, which bears six acuminate recurved ones.

[Described from specimens Hopk. U. S. 9724.] 
This species infests the trunks of small red maples (Acer rubrum), causing a gall-like swelling in which the larvae feed. Before pupation a straight burrow is extended into the heartwood, above or below the gall. At the extremity of this the larva pupates, the adult crawling back and emerging through the gall. The work is common throughout the eastern United states and Canada. Observations by $\mathrm{A}$. B. Champlain and the author.

\section{XYLOTREGHUS QUADRIMAGULATUS Haldeman}

\section{[Pl. XL]}

Distinguished from aceris in that the ampullae are not entirely covered by pubescence, but the centre is glabrous, dull granulate; dorsal ampullae without pubescence on anterior edge; first joint of antennae transverse, second about one and one-half times as long as thick; labrum slightly wider than long; abdominal spiracles more narrowly oval except first and last.

Pupa: Similar to aceris but spines all more slender and not so heavily ehitinized, the two median ones on each abdominal tergum conspicuously larger than others.

[Deseribed from specimens Hopk. U. S. 9768 and $9785 f^{2}$.]

The larva has the peculiar habit of girdling branches of Betula and Fagus. It cuts the branch from the inside, causing it to drop early in the fall. It then constructs a long burrow up the centre. The work is often common in Betula on the tops of mountains. Observations by F. E. Brooks and the author.

\section{GLYTANTIIUS RURICOLA Oliver}

\section{[Pl. XIX]}

Form semirobust, cylindric, contracted; integument rather firm, shining, sparsely covered with short light yellow hairs.

Head subtrapezoidal; mouth-frame corneous; labrum thick, transversely broadly oval, having a very few short hairs; mandibles robust, broader at apex than other Clytini, shining basal pieee about one-third length of apical; first joint of antennae globular, one-half length of second, equal to last; one distinct ocellus contiguous with base of antennae; process of palpifer minute; joint of maxillary palpi equal in length, last equal to last labial; gena neither shouldered nor setose.

Prcthorax stout, trapezoidal, sparsely hairy, the hairs short, castaneous; pronotum anteriorly regularly and sparsely haired, posteriorly alutaceous, shining to dull, granulate on hind margin, median suture deeply impressed; sternal glabrous spots smooth, shining or reticulate. Mesonotum and metanotum dull granulate; legs minute chitinous spines.

Abdomen: Ampullae dull, granulate, not surrounded by velvety pubescence. Pleural dises indistinct. Spiracles broadly oval, peritreme rather thiek.

Pupa: Pronotum regularly beset with acuminate points resembling short stiff hairs, except on centre; abdominal terga bearing acuminate points, those on the first six segments projecting posteriorly, on the seventh segment four much larger and reeurved; two similar ones on eighth.

[Deseribed from speeimens Hopk. U. S. 11815 and 11861a.]

This species very closely resembles Nylotrechus comergens and can scarcely be separated generically. The form is more slender, the granulation of ampullae coarser, and the spines representing the legs always distinet and larger.

The larva has been found in Acer, Hicoria, Sorbus, Betula, and Fagus. It is always in decaying wood associated with a fungus marked by irregular black lines in the wood. Range, eastern United States and Canada.

\section{CLYTOLEPTUS ALBOFASGIATUS Laporte (Casey)}

Form more slender and cylindric than in ruricola; integument shining, hairs light castaneous, finer and more dense.

Head roundly trapezoidal; moutl-frame lightly corneous, labrum transversely oval; basal piece of mandible one-half length of apical; first joint of antennae globular, about one-half length of second; one very large white ocellus; gena bearing a few long sctae; last labial joint longer than last maxillary, which in turn is longer than seeond; anterior edge of hypostoma very shallowly but broadly notehed by insertion of submentum.

Pronotum having median suture decply impressed behind, posterior area coarsely and somewhat obliqucly striate; ampullae alutaceous, shining often subtuberculate; no trace of ventrolateral suture. Legs minute, fleshy, two-jointed. Spiracles broally oval, peritreme thin, somewhat sunken.

[Described from specimens Hopk. U. s. 11544b.] 
Thas larvat from some chandeters might be regareled as belonging to the Anoglypti. It is as distinctly separable from C'lytunthus ruricola as clytanthus is form. Vylotrechus and may in that sense be retained as a genus, to which rank

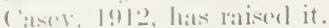

it las ixen fommel in deat grapevines (Titis) associated with Phymatodes mmou mes and also in partially living vines. The mines are rather extensive and tightly packinl with frass. Range, eastern Lnited fitates and Canada.

\title{
Tribe ANAGLYPTI
}

These larva are more slender in form than those of the Clytini and the ampuliae are small, ovil, with al dere median furrow. Head rather broar in front, produeed by distinetly shouldered genil anclusing a large ocellus (larger than spiracles); last joint of maxillary palpi mueh longer than second; process of palpifer relatively large. P'ronotum posieriorly striate, not projecting forward along median line, no median suture; no traee of ventro-lateral suture; sternellar fold distinct at extrenities; legs two to four jointed, shorter than maxillary palpi.

The affinities of this tribe evidently ally it with clytini, but the group serms to be distinct enough to be regarded as of equal rank with the latter. The charaters suggest eertain species of Callidini.

\section{KEY TO THE GENERA OF ANAGLYPTI}

(iena very strongly shouldered, somewhat tubereulate; striae of pronotum very fine. Cyrtophorus (ienis not so strongly shouldered, nor so corneous; pronotal striae coarse.

lirst antennal joint longer than wide, first and second subequal; body smooth, shining.

First antenual joini rlobular, much shorter than seeond; body finely granulate. Tillamorpha

\section{GYRTOPIIORUS VERRUCOSUS Oliver}

\author{
[Pls. IX, X, XIX]
}

Form rather slender: integument thin, shining, densely eovered with fine yellowish hair.

Ilead broad in front, mouth-frame lightly corneous; labrum thick, transversely oval to suborbicular; mandible rather broad at apex, basal piece reddish-brown, one-fourth width of apical; first and second antennal joints seareely longer than wide, first slightly shorter than second, supplementary rather long, acute; one large, white ocellus enveloped by the abruptly shouldered tuberculate gena; gena setose; first and second joints of maxillary palpi transverse, third much longer, equal to last labial; process of palpifer distinet.

Prothorax transversely rectangular; pronotum posteriorly finely siriate, shining, then granulate, no median suture; no traee of ventro-lateral suture. Legs shorter than maxillary palpus, threc-jeinterl.

Abdomen: Ampullae small, shining, granulate, indefinitely marked, but with a deep median furrow; pleural dises indistinet. Spiracle broadly oval, much smaller than ocellus, peritreme thin.

Pupa: Pronotum regularly beset with erect, slender, acute chitinous points; shorter ones on mesonotum and metanotum; stouter spines with a papilla-like base on each abdominal tergum arranged more or less in rows, six on posterior margin of seventh tergum (in groups of three) and four on eighth.

[Described from specimens Hopk. U. S. 12254.]

The larva works like a Veoelytus in solid dead Quercus where it is often associated with $N$. longipes. The life cycle is completed in one year, the adults transforming in the fall or early spring. It has been collected also from Prunus, Cormus, Pymus, Diospyros, Betula, Benzoin, and Acer. Range, eastern United states and Canada.

\section{MICROCLYTUS GAZELLULA Haldeman}

\section{[Pl. XIX]}

Form slender, somewhat tapering; integument smooth, shining, very hairy. Head similar to that of Tillamorpha except that the genae are not so corneous; the labrum is thin and transversely semicircular, much wider than long; the last palpal joints are relatively longer, though not quite twice the length of the second; first and second joints of antennae subequal, longer than wide.

The striae of the pronotum are distinetly separated, rather coarse; mesonotum and metatergum granulate while not noticeably so in Cyrtophorus. Legs very small, three or four joints, joints globular. Impullae coarsely granulate. Spiractes broadly oval, peritreme thin. 
Pupa: Several long setae on head, a transverse row on anterior and posterior margin of pronotum, as also on each abdominal tergum becoming more numerous and longer posteriorly; several on articulation of femur and tibia.

[Deseribed from specimen Craig. 364, eolleeted at State College, Pa.]

This larva feeds in the outer scaly bark of Quercus, usually associated with Encyclops caemlens. The life cycle is completed in one year, the adult transforming in the fall or early spring. Observations by the author in Pennsylvania. IV. S. Fisher records it from IIicoria.

\section{TILLAMORPHA GEMINATA Haldeman} hairs.

Form rather slender; integument shining, very finely granulate, covered with fine whitish

Head transversely oval, slightly tapering anteriorly; mouth-frame lightly chitinized; labrum thin, transversely oval, mandible broad at tip, basal piece recklish-brown, about onethird length of apieal, latter piceous, shining, bearing a longitulinal fovea on outer face; first antennal joint globular, much shorter than seeond, supplementary long; oeellus large, white, prominent, contiguous with antennae, enclosed by corneous-shouldered gena, which bears no hairs; last joint of maxillary palpi equal to last labial, shorter than seeond; process of palpifer distinct.

Prothorax widely transverse; pronotum slightly wider than long, anteriorly beset with a few slender hairs, posteriorly irregularly and faintly striate, then dull granulate, no median suture; no trace of ventro-lateral suture. Legs very small, fleshy, three-jointerl.

Abdomen: Dorsal and ventral ampullae dull, granulate, granules distinet, flattened. Pleural dises not distinet. Spiraeles smaller than ocellus, orbieular, peritreme thin.

Pupa: Very similar to that of Cyitophorus verrucosus, but the mesonotum and metanotum are unarmed and only four spines oeeur on the posterior boder of the sevenih tergum and two on the eighth.

[Described from specimens Hopk. U.s. $9789^{\circ}$.]

Habits resemble those of a Neoclytus, as it mines between the bark and wood, but only goes into the latter to pupate. Occasionally pupation takes place beneath the bark. It pupates very early in the spring. The larvae have been collected in Quercus, Nyssa, Hicoria, Titis, and Cormus. ()bservations by H. B. Kirk and the author.

Tillomorpha has been associated with Euderces by some writers, but its affinity through larval characters is not at all distinct. It is much more closely allied to Microclytus and Crytophorus by the form of the head, the shouldered gena, and the sternellar fold, which is not broadly fused into the epipleurum, as in Euderces.

\section{Tribe MOLORCHINI}

The following genera form a very homogeneous group of larvae. They are evidently allied to Curius and in some respects to Rhopalophora. The adults have been placed in two tribes, but the larvae do not warrant such a grouping. They can be recognized as follows:

Head depressed, transversely oval, widest about middle; gena not slouldered, bristles numerous; one or no ocelli; first and second joints of antennae very short, usually subequal; last joint of maxillary palpi always much longer tlan seeond; proeess of palpifer rather large; pronotum posteriorly striate, median suture rarely impressed; sternum short and broad; eusternum often distinct; ventro-lateral sutures oblique, widely diverging anteriorly; sternellar fold not passing spiracles and usually somewhat fused into epipleurum; legs absent or very sinall. Ampullae often bilobed, granulate; pleural dises indistinet; spiracles very small, sunken.

The peculiar bilobed ampulla in this group occur in Obrium rufulum and callimoxys fuscipennis. Dorsally it is produeed as much by the extension of the paraseutal region, and ventrally as mueh by hypopleurum and eoxal lobe, as by the ampulla itself. On segments bearing these unusual ampullae the paraseutal and hypoplenral regions are very conspicuous from the side.

\section{KEY TO THE GENERA AND SPECIES OF MOLORC'HINI}

Labrum not twiee as wide as iong; legs essentially wanting.

Ocellus distiner; ampullae deeply bilobed; median suture of pronotum impressed.

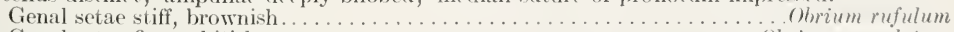

Genal setae fine, whitish...

Obrium maculatum

Oeellus indistinet; ampullate not deeply bilobed, dull granulate; median suture of pronotum absent.

Last joint of maxillary palpi twiee length of second; prosternum coatrsely granulate.

Labrum twice as wide as long; legs three-jointed; ampullae deeply biloberl.

Molorchus bimaculatus

Callimoxys fuscipennis 


\title{
OBRIUM RUFULUM Gahan RUBRUM Newman
}

\author{
[Pls. XVIII, XIX, XXX.]
}

finm very clongate, slemler, cylinlrie; integument thin, shining, sparsely eovered with fine whitish hairs.

Iheud depressecl, transversely oval; mouth-frame seareely corneous; clypeus and labrum thin, latter rectangularly oval, sparsely hairy; mandibles robust, basal piece reddish brown, alout one-thirel length of the distal, latter piceous, shining; antennae short, first and second joints glohular, transverse, second slightly longer; ocellus large, not protruding; gena not shouldered, bearing numerous long, rather stiff brownish bristles. Ventral mouth-parts rather clongate, last joint of labial and maxillary palpi slender, twice the length of second maxillary joint; process of palpifer large, distinct, also a process on first joint of maxillary palpi; gula triangular, distinet.

Prothmax lepressed; pronotum rectangular, about twice as wide as long, uniformly hairy in front, posteriorly shining, with a few widely separated striae, often a faint median suture; sternum very broad, narrow; eusternum faintly distinct; ventro-lateral suture faint, oblique; sternellar band fused into lateral region at extremities. Mesonotum and metanotum dull, granulate. bach leg an almost invisible joint.

Abdomen very slender, with wide intersegmental skin; first and second dorsal and ventral amp illite dull, granulate, third, fourth, fifth and sixth deeply bilobed, the lobes teat-like, projeeting; intersegmental skin between fifth and sixth dorsal ampullae dull, coarsely granulate. Pleural dises not distinet. Spiracles orbicular, very minute, smaller than ocellus, peritreme thin.

Pupa: Several long setae on dise of pronotum and a large group near posterior border, mesonotum and metanotum glabrous; third, fourth, fifth and sixth abdominal terga bearing an anterior irregular band of fine, slender, curved points and a posterior band of setae; seventh with two large hooks on posterior margin.

[Described from specimens Hopk. U. S. 978te1.]

The larva has been found only in the dead branches of ash (Fraxinus). It works beneath the bark for a short time, spending most of the larval life in the wood. Several generations continue to breed in the same twigs, which they completely honeycomb. This is a true dry wood borer. The mines are tightly packed with granular frass. One year is required to complete the life cycle. Range, eastern United States and Canada. Observations by A. B. Champlain and the author.

\section{OBRIUM MACULATUM Oliver PHYTON PALLIDUM Say}

In gencral as in $O$. rufulum, but differing in having a less elongate form and shorter body hairs; genal bristles fine, whitish; ocellus rather indistinct; process of palpifer as long or longer than entire palpus; gula longitudinally striate; posterior area of pronotum raised, extending forward in the middle, faintly and sparsely striate; dorsal ampullae projecting, marked by a single transverse fold (in rufulum two folds are present).

[Described from specimens Hopk. [T.S. 15128].

The larva breeds in branches of Quercus, Celtis, Acacia Hicoria, Morus and Castanca. It does not bore so extensively in the wood as $O$. mufulum. The life cycle is completed in one year. Range, eastern United States and Canada.

\section{MOLORGHUS BIMACULATUS Say.}

\section{[Pl. IX, XLII]}

Form depressed, elongate, tapering posteriorly; integument thin, shining, sparsely covered with fine whitish hairs.

Head as in Obrium rufulum, but thicker in front; one indistinct ocellus; genal setae more numerous and longer; first and second antennal joints transverse, subequal, third longer; last joint of maxillary palpi as long as two transverse basal ones; process of palpifer distinet.

Pronotum about twice as wide as long, posteriorly reticulate, shining, then dull granulate; sternum coarsely granulate, shining. Mesonotum and metanotum granulate, shining. Legless.

Ampullae coarsely granulate, shining. Pleural dises indistinet. Spiracles very minute, inconspicuous, orbicular, peritreme thin.

Pupa: Three transverse groups of long setae on pronotum; mesonotum and metanotum glabrous; several finer setae on second abdominal tergum, third, fourth, fifth and sixth abdominal terga bearing two groups of from three to six small chitinous setiferous points; two reeurved points and several setae on seventh; eighth bearing many long setae.

[Described from specimens Hopk. U.S. $11847 x$.] 
This species attacks a variety of recently dead trees, mining the smaller branches. The larvae practically mature beneath the bark, making irregular mines 8 to 10 inches long. On entering the wood a long curved pupal cell is made, often 3 inches in length. At the posterior end the larva pupates behind a wad of fibrous frass. One generation occurs each year, but the larvae mature very rapidly. From eggs laid in April pupae and adults can be found in late August. The adults hibernate in the cells. It has been reared from Cercis, Cornus, Liquidambar, Castanea, Quercus, Vitis, Juglans, and Acer. Collected by A. D. Hopkins, W. F. Fiske, H. B. Kirk, J. N. Knull, and the author.

\section{CALLIMOXUS FUSCIPENNIS LeConte}

[Pl. XXI]

Form more robust, quadrangular, tapering posteriorly; integument thin, shining, sparsely covered with whitish hairs.

Head as in Obrium maculatum; labrum transversely oval, nearly twice as wide as long; ocellus large but little protuberant; first and second joints of antennae subequal, about as long as wide, third longer; last joint of maxillary palpi not quite twice length of second; process of palpifer and that of first maxillary palpal joint distinet, the former larger.

Prothorax thick, pronotum but little wider than long, anteriorly sparsely hairy, posteriorly regularly striate; sternum alutaceous, shining. Third, fourth, fifth and sixth ampullae deeply bilobed, teat-like, conspicuously projecting. Legs minute, two or three-jointed. Pleural dises indistinct. Spiracles very small, inconspicuous, suborbicular, peritreme thin.

[Described from specimens Hopk. U. S. 13165b.]

Habits and seasonal history similar to those of Molorchus bimaculatus. Specimens collected by H. B. Herbert from Ceanothus thyrsiflorus, Muir Woods, Cal.

\section{Tribe CURIINI}

The larva of Curius has many striking characters by which it is easily recognized. These peculiarities are found also in Euderces. None of the adult systematists have suggested such relationships for these forms, but as larvae they will be here considered together. A peculiar character common to both, though probably of little taxonomic value, is the rugose texture of the ventral intersegmental skin between the middle abdominal segments. The affinities point towards those forms about Obrium. They may be recognized as follows:

Process of palpifer unusually long; last joint of maxillary palpi very long; gena not shoul dered, bristles long (numerous in Curius, few in Euderces); ventro-lateral suture absent; sternellar fold broadly fused at extremities into epipleurum; hypopleural area of abdomen strongly protuberant laterally; pleural dise rather indistinet, but somewhat granulate; legs very small, three-jointed, form contracted.

Genal setae numerous; median suture of pronotum not impressed

Genal setae few, four in a row; median suture impressed. .

Curius dentatus Euderces picipes

\section{CURIUS DENTATUS Newman}

\section{[Pls. IX, XV, XX, XIX]}

Form stout, very much depressed; integument thick, shining, sparsely covered with fine whit ish hairs.

Head depressed, trapezoidal, wide behind and very suddenly narrowed in front; 1nouth frame corneous, smooth; clypeus and labrum thick, latter rectangularly oval, coarsely punctured; mandibles dull, except tips, broarl, basal piece about one-third width of distal; antennae, fleshy, first and second joints subequal, little longer than wide, third longer, supplement:ury minute; ocellus large, protuberant; gena not shouldered but densely covered with skencler bristles; ventral mouth-parts quite long; first and second joints of maxillary palpi transverse, last twice length of second, equal to last labial; proeess of palpifer as long as last maxillary joint.

Prothorax depressed, trapezoidal; pronotum trapezoidal, about two-thirds as long as wide, anteriorly sparsely hairy, posteriorly dull, covered with small, flat, regular granulations, no median suture; sternum broad, posteriorly granulate; ventro-lateral suture not impressed; sternellar fold short, protuberant at extremities and broadly fused into epipleurum. MIesonotum and metanotum dull, granulate. Legs minute, three-jointed, very short.

Abdomen depressed; hypopleural area strongly protuberant laterally, as well as spiracular region; dorsal ampullae broad, flat, dull, granulate, no markings; ventral similar except that the third, fourth, fifth and sixth are clivided in the middle by a longitudinal band of very rugose, semi-corneous texture. Pleural dises on second abdominal segment dull, granulate. ipiracles minute, smaller than ocellus, sub-orbicular. 


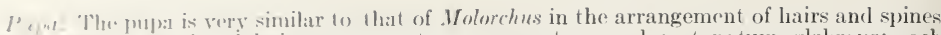
There tramererse lands of hairs on pronotum; mesonotum and metanotum glabrous; rach mbetemumal tergum bestring two transverse rows of vory small points, arranged in four groups the I wo anterior smaller; the seventh and righth lave several large recurved spines and the

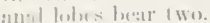

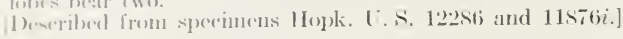

The litria feok between the bark of small branches of Pinus, Taxodium, and Juniperus. I fow specimens were also reared from dead branches of Acer at lalls ('hureh, Va. It deeply seores the wood, later often extending a long mime through the twig and finally making a broad, flat pupal cell nearly at right angles to the grain. The life cycle is completed in one year. Range, southeastern Inited Ftates. Obsorvations by A. D. Hopkins, W. F. Fiske, and the author.

\title{
EUDERCES PICIPES Fabricius
}

\author{
[Pls. VIII, XVIII, XIX]
}

Form semi-robust, short, contracted; integument tough, shining, sparsely covered with fine whitish hairs.

II eal suboval, widest behind, with a slight anterior taper; mouth-frame lightly corneous: clypeus rather wide; labrum thin, transversely oblong; mandibles broad at apex, basal piece nilrow, reclelish brown, about one-fourth width of apical, which is piceous, shining, with a shallow fovea on outer face; antennae slender, second and third joints subequal, third about equal to fourth, supplementary long, one-half length of fourth; ocellus large, white, not very protuberant nor contiguous with antennae; gena abruptly rounded, searcely shouldered, bearing a row of four long setae behind ocellus. Ventrai mouth-parts rather long, curving over lower face of mandible, bearing numerous long hairs; last joint of maxillary palpi much longer than seronl, slightly shorter than last labial; process of nalpifer as long as last maxillary joint; gula narrow, sutures protuberant, concave.

Prothorax subrectangular, rather thick; pronotum little wider than long, anteriorly regularly though sparsely hairy, posterior area with a few irregular faintly impressed st:iae ending in an irregular band of lenticular punctures, then finely granulate; median suture impressed; sternellar band at extremities broadly fused into epipleurum. Legs not longer than maxillary palpi, of two globular joints and a minute fleshy spine.

Abdomen rather contracted; ampullae prominent, last three dorsal ones, oval, dull, granulate, granules rather flat, with faint lateral impressions and median furrow; hypopleural region strongly protuberant; skin between fourth and fifth ventral ampullae strongly rugose. Pleural dises granulate on first, second, and third segments. Spiracles smaller than ocellus, sub-orbicular, peritreme thin.

[Described from specimens Craighead collections 238s.]

The larva constructs long mines beneath the bark, entering the wood to make a short pupal cell. The adult is common on flowers. Larvae have been collected from Castanca, Hicoria, Quercus, Cercis, Celtis, Juglans, Robinia, Nyssa, Cormus, and Pyrus. Range, eastern United States and Canada.

\section{Callichroma Plicatum Leconte}

[Pl. IX, figs. 5 and 8]

Form robust, cylindric, tapering.

II red broad behind, tapering rapilly to a narrow front; mouth-frame seareely corneous; epistoma thick, abruptly protuberant, wrinkled; clypeus small; labrum large, very thick, oblong, rectangular; mandibles tapering to apex, broad at base, yellowish basal piece as wide as jiceous, shining distal piece; seeond joint of antennae, about as long as wide, covered with minute fine pubescence; one small ocellus, prominent, distinctly separated from antennae. (ima not shouldered. covered with very fine short pubescence, as is also the front of the head. Ventral mouth-parts fleshy; palpifer and maxillary palpus pubescent; joints of maxillary palpi subequal, first transverse, third slender, equal to last labial; process of palpifer very minute; ligula so small as to be concealed.

Prothorax sparsely covered with very short fine hairs; pronotum posteriorly embossed and irregularly closely striate, median suture impressed behind; sternellar fold not passing beyond spiracles. Legs of three large globular joints and a short spine-like tarsus. Spiracles oval, peritreme thick.

Deseribed from two poor specimens in the U.S. National Museum, collected in Horus at sarannah, (ia. cussed.

Until better material can be had for study, further details cannot be dis- 


\section{Tribe RHOPALOPHORINI}

Rhopalophora undoubtedly represents a distinet tribe. Its position is rather perplexing, but it shows affinities toward Heterachthes and also those forms about .11olorchus. The characters are described under the species.

\section{RHOPALOPHORA LONGIPES Say.}

[Pl. XXI, fig. 1; Pl. XV, figs. 1 and 12.]

Form elongate, subcylindric; integument firm, shining, smooth, sparsely covered with short, fine, light yellowish hairs.

Head subtrapezoidal, rapidly narrowing on front, mouth-frame slightly corneous; epistoma broadly emarginate in middle; clypeus thin, short; labrum transversely oblong, thin; mandibles rather broad, basal half reddish brown, one-third width of distal, latter piceous, shining, suleus on outer face; antennae rather stout, first joint globular, equal to slender third, shorter than second, supplementary very minute; two bead-like, prominent oeelli below antennae, not enveloped by gena, whieh is beset with a number of rather stiff bristles; last joint of maxillary palpi about $t$ wice the length of transverse seeond, about equal to last labial; process of palpifer and that of first maxillary joint, large, distinct.

Prothorax narrowly rectangular, depressed; pronotum twice as wide as long, posterior area embossed, very regularly and finely striate, sparsely haired, no median suture; sternum narrow, transverse; ventro-lateral sutures very obliquely diverging; sternellar fold not distinet beyond spiracle. Mesonotum and metanotum granulate, shining, former with an inverted $\mathrm{v}$-shaped impression (i.e., scutellum distinet), the latter with a transverse suture.

Legs well developed, four-jointed, femur and tibia about equal in length to maxillary palpi.

Abdomen cylindric, segments deeply constrieted; ampullae small, bearing two irregular rows of small shining tubercles, last ventral substriate. Pleural dise a very large, dull, finely striate area on second, third and fourth abdominal segments.

Spiracles suborbicular, very small (about size of ocellus), peritreme thin.

[Described from specimens Hopk. U.S. 1184ta.]

The larval habits of this species are similar to those of Molorchus bimaculatus, but the adult does not transform until the spring. It has been reared only from Cercis. Collected by A. D. Hopkins, T. E. Snyder, and the author.

\section{TYLONOTUS Haldeman}

This is the only larva of the adults generally associated with it that has been studied, except Chion and Eburia. It can in no way be grouped with Chion but does show a relationship to Eburia, Romaleum, and the species of Elaphidion having two ocelli. The larva of the European Stromatium can be placed with it. The writer regards it as a form intermediate between Malcopterus and the true species of Elaphidion.

\section{TYLONOTUS BIMACULATUS IIaldeman}

\section{[Pl. IX, fig. 7; Pl. XXI, fig. 4; Pl. XVIII, fig. 2; Pl. XY, fig. 13]}

Form subeylindric, elongate, slender; integument rather firm, shining, sparsely covered with short, light yellowish hairs.

Head roundly reeiangular, almost suborbicular; mouth-frame corneous, smooth, greenish brown; elypeus long as librum, latter transversely oval, somewhat stalked, ciliate in front : mandibles rather slender, entirely black, basal pieee about one-half length of disial; antenna slender, first and second joints subequal, or first a litile shorter, third shoricr; supplementary minute; oeellus large, clear, projecting, contiguous to antennae, not enelosed by genia (i.e., gena not shouldered). Ventral mouth-parts: palpi slender, last joint of maxillary palpus slightly longer than second, about equal to or slightly shorier than hast labial; process of palpifer distinct.

Prothorax about two-thirds wider than long, four tergal plates distinct, ochraceous; pronotum slightly wider than long, anteriorly sparsely hairy, hairs short, posteriorly fincly and regularly striate, median suture not impressed; stermum narrow, eusternal spots contiguous, glabrous, wrinkled, shining; ventro-lateral suture a mere notch; sternellar fold not passing spiraeles, distinct at extremities. Mesonotum having scutellum distinct; metanotum with a transverse impression. Ifegs very short, three-jointed, bisil joints transverse, shorter than maxillary palpi.

Abdominal segments elongate, space between ampullae (intersegmental skin) twice wider than ampullae; dorsal ampullae projecting, oval, finely ahutaeeous, shining, markel by two lateral and two transverse impressions, setting off a fusiform area. Pleural dises indistinet. Spiraeles broadly oval to orbicular, peritreme distinct.

$57951-5$ 
1. J'monom howet with a few short stiff hairs on a papilla-like base; mesonotum gliducus. unctimotmm having a fow very small points on posterior half; two groups of small componl prints on the posterior half of rach abdominal tergum, becoming larger pesteriorly and very linge on serenth and righth, the latter loving six on the hind margin.

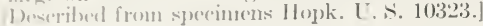

The larvat ustally is found attacking living ash (Fraxinus) trees, and it often kills them. It mines beneath the bark and wood, first in the larger branches and later in the main trunk as the trees become weakened. It is often associated with several species of cossicls. Immature larvae and pupae can be found at the same time, indicating a life-cycle extending over several yours. Range, eastern United States and Canada. Observations by A. D. Hopkins, II. F. Fiske, A. B. Champlain, J. L. Webb, and the author. It occasionally attacks privet hedges (Ligustrum), causing the death of the plants.

\section{Tribe EBURIINI}

LeConte (20) placed Eburia in the group C'erambyci with Chion, Elaphidion ote. Lacordaile (19) makes a separate tribe of this and allied forms. Based on lirval characters Lacordaire's grouping seems more natural, as these forms are quite different from the others with which they have been tribally associated on imaginal characters. They can be recognized as follows:

Form robust, euneate; labrum large, fleshy; gena bearing no setae and usually one large ocellus; pronotum posteriorly striate, with a deeply impressed median suture; ventro-lateral sutures strongly impressed behind; sternellar fold distinet at extremities; legs long, four-jointed; pleural dises not granulate, rather indistinet.

If a larger number of species was available for study it is doubtful if these two genera could be separated.

\section{KEY TO THE GENERA OF EBURIINI}

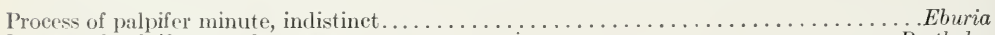

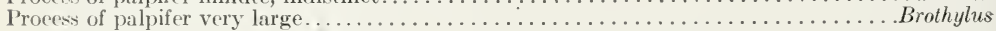

\section{EBURIA QUADRIGEMINATA Say.}

\section{[Pls. XXI, XXVIII]}

Form euneate, compressed posteriorly, robust; integument tough, shining, sparsely covered with slender golden hairs, mouth-frame corneous, dark orange to lemon-coloured; clypeus very short; labrum thick, suborbieular, somewhat stalked, very hairy; mandibles short, stout, basal piece ochraceous, wide, two-thirds shorter than distal, latter black, piceous with a sulcus on outer face; antennae slender, first and second joints subequal, each twice or more as long as wide, third shorter, supplementary minute; ocellus large, white, contiguous to base of antennae, enveloped by the somewhat shouldered gena. Ventral mouth-parts rather thick, corneous; last joint of maxillary palpi, shorter than second, shorter than last labial; process of palpifer very ininute; gula parallel, anterior margin sunken.

Prothorax very thick, quadrangular, with four prominent, pale yellow plates; pronotum a little wider than long, anteriorly covered with short hair, posteriorly alutaceously striate, with numerous lentieular impressions, median suture entire, deep behind; sternum hairy, wrinkled except two glabrous spots on eusternal area; ventro-lateral sutures impressed behind. Metanotum having a transverse impression. Legs four-jointed, long, tarsus chitinous-tipped.

Abdomen laterally compressed; dorsal ampullae alutaceous, shining, marked by two lateral and two transverse impressions. Pleural dise wrinkled, indistinet. Spiracles large, narrowly oval, peritreme indistinct.

[Deseribed from specimens Hopk. U. S. 9791l.]

This larva is a true heartwood borer in Quercus, Hicoria, Robinia, Fraxinus, and Castanea, so far as recorded. It prefers dry solid wood, in which it excavates large contorted mines very tightly packed with frass. Mature oaks having a "catface" or scar through which the larvae can gain access to the heartwood are often badly damaged. A correspondent sent in a larva taken from a wooden bed which had been is use over 20 years. Dr. Hopkins records the adults under the bark of Clmus and Fagus. 


\section{EBURIA sp.}

(Probably ovicollis LeConte or mutica LeConte)

Form, texture, and in general as in E. quadrigeminata, except that the hairs on the budy are finer and lighter in colour. The posterior pronotum is more fincly striate, these striae tending to be somewhat finely reticulated; ampullae alutaceous to flat, granulate.

[Described from two specimens in the U.S. National Museum collected at Brownsville, Tex., May 24, 1905, by H.S. Barber, in the wood of huisache (Acacia)].

\section{BROTIIYLUS GEMMULATUS LeConte}

The form, texture, and general characteristies are similar to those of Eburia, but this larva differs in having a large process of the palpifer about equal to the last joint of the maxillary palpi, and also a process on the first palpal joint; last joint of antemnae less than half the length of the second; ocellus indistinct; gena more abruptly shouldered; submentum inore deeply sunken below edge of hypostoma.

[Deseribed from specimens Hopk. U.S. 12614 and 12618c.]

Mr. A. B. Champlain collected these specimens from the base of dry dead scrub oaks (Quercus) in Colorado. The samples of work were similar to those of Eburia quadrigeminata.

\section{Tribe PHORACANTHINI}

The larvae of the species included in Romaleum, Eustroma, Aneflus, and Elaphidion (in part) constitute one of the most easily recognized groups of the Cerambycinae. It is impossible to group the larvae of the species here considered, as they are arranged in adult classifications, but a simpler arrangement is possible by splitting the genus Elaphidion. Romaleum and Eustroma can be separated from the species of Elaphidion but not by very good generic characters. Eustroma is more like Romaleum atomarium than is the latter like $R$. rufulum. Again, the species of Elaphidion, 10500a, 10961d, and 10055, are much more distinct from forms like mucronatum than are the latter from Romaleum, and are considered, from the larval standpoint, as a distinct genus.

Some species of Elaphidion cannot be even grouped with those discussed in the preceding paragraph. E. alienum is closely allied to Stenosphenus and is here treated with it. Those forms about $E$. tenue, etc., are still more distinct and are regarded as a transition from the Stenosphenus-like species to those of the tribe Stenaspes.

The species of Romaleum, Eustroma, and the species of Elaphidion which have two ocelli may be characterized as follows:

Form elongate, produced by wide intersegmental skin; head usually depressed; normally two ocelli enelosed by a more or less shouldered gena; process of palpifer large, small in a few species; prothorax depressed, sternal region very broad for its length; pronotum posteriorly having a few coarse striae, median suture impressed; ventro-lateral suture impressed behind; eusternal glabrous spots more or less fused; sternellar fold distinct at extremities; mesonotum and metanotum with $\mathrm{x}$-shaped impressions; legs rather long, four-jointed, without tarsus: longer than maxillary palpi; ampullae alutaceously tuberculate, having two lateral and two. transverse areuate impressions, also a deep median furrow; pleural dise indistinet or a deep pore in some species.

\section{KEY TO THE SPECIES OF ROMALETM, ELSTROMA, AND THOSE OF ELAPHIDION HAVING TWO OCELLI}

Process of palpifer distinct; pleural dise indistinct, erowded by a tuberele; spiracles larger..... I Process of palpifer minute, indistinct; pleural dise distinet, finely granulate; spiracles smail,

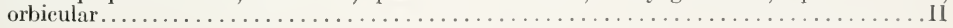

Ocelli one or indistinetly two, erowded by a chitinous fold on pleurostoma; hairs on lateral region of prothorax stiff, subulate.

Ocellus one, large not sunken in fovae produced by fold of gena.

Hypostoma transversely and coarsely wrinkled.

Romaleum sp. $11 \times 71$

Hypostoma longitudinally (to head) and finely wrinkled.

Romaleum rufulum.

Ocellus one or indistinctly two, in a deep fovea.

$57951-5 \frac{1}{2}$ 
(1)e or raredy no ocellus; process of palpifer not so long as last joint of maxillary palpi.

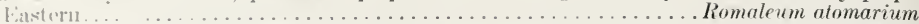
Two very snall ocedli; process of palpifer large, as long as last joint of maxillary palpi. II ()erlli two, distinct; hairs on lateral region of prothorax more slender.

Iabrum suborbicular.

Ifeal in cross-section twiec as wide as decp; hairs on labrum not as long as labrum itself.

Ilead not so depressed; hairs on labrum longer than labrum itself.

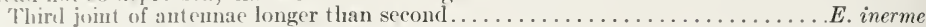

Third joint of antemine shorter than second...................... villosum Ialsom witer than long.

lipistoma broadly curved; spiracles suborbicular................... incertum Listoma broally curved; spiracles oval. ........................ sp. 12283L Fistoma nearly straight; spiracles oval........................... arizonense

Epistoma shallowly emarginate.

fiecond joint of antennate longer than first.

First and second joints of antemiae equal. E. sp. $10500 a$

................................ 1005.5 Epistoma suldenly and deeply emarginate behind clypeus; second joint of antennae longer

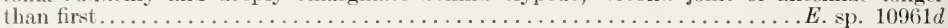

\section{ROMALEUM RUFULUM Haldeman}

[Pl. I, fig. 6; Pl. VIII, fig. 13; Pl. XX, fig. 6; Pl. XIX, fig. 13; Pl. XVIII, fig. 9; Pl. XV, fig. 3; Pl. XXXIX, fig. 1 ; Pl. XL]

Form robust, elongate, anteriorly depressed; integument tough, firm, shining, sparsely covered with short, coarse, castaneous hairs.

Ilead roundly rectangular, slightly narrowed in front; mouth-frame heavily corneous, piceous; labrum transversely oblong, hairs short, stiff; mandibles stout, piceous, basal piece about one-half length of distal, fovea on outer face; antennae slender, first and second joints subequal, third slender, shorter, supplementary a mere point; ocellus large, globular, clear, somewhat enveloped by gena. Ventral mouth-parts more corneous than usual; last joint of maxillary palpi more slender and shorter than either second or last labial; process of palpifer distinct; hypostomal edge finely longitudinally wrinkled, the outer striae becoming transverse; gula longer than wide.

Prothorax depressed, little more than twice as wide as long; hairs on lateral region short, subulate, ferruginous; pronotum nearly twice as wide as long, with a border of short hairs on anterior margin, posterior area slightly embossed, protruding forward in centre, irregularly pinnately striate; median suture faintly impressed behind; sternum narrowly rectangular, very broad; ventro-lateral sutures distinct; mesonotum and metanotum bearing $\mathrm{x}$-shaped impression. Legs long, four-jointed.

Abdomen: Dorsal ampullae broadly oval, alutaceous, shining, marked by two lateral and two transverse impressions. Pleural dise wrinkled, indistinct. Spiracles broadly oval, peritreme corneous.

Pupa: Pronotum, mesonotum and metanotum sparsely and rather regularly beset with minute erect asperities; abdominal terga armed with well-dispersed, erect, acute spines which become larger and curved posteriorly, arranged in a somewhat oval figure, none on eighth segment.

[Described from specimens Hopk. U. S. 10926 and 11863d.]

The habits of this species somewhat resemble those of Prionoxystus and Croes, as they attack living oak trees (Quercus). The egg is laid under scales of the bark and for the first year the larva mines beneath the bark or merely starts its burrow in the wood. During the second year a long upright gallery is made deep into the heartwood at the extremity of which pupation occurs. The adult emerges back through the gallery at the point where the egg was laid. Large quantities of frass are exuded and the mine in the wood is ahwas open. It is of considerable economic importance. Range, through central and eastern United States and Canada. Observations by the author.

\section{ROMALEUM ATOMARIUM Drury}

[Pl. X, fig. 2]

Very similar to rufulum, but easily distinguished by having a very small and narrowly ova occllus (or none) besides the antennae, set in a deep groove produced by a large chitinous wrinkle of the gena; anterior edge of hypostoma smooth, not wrinkled; ampullae more wrinkled. 
Pupa: Pronotum, mesonotum and metanotum glabrous, spines of abdominal terga arranged more transversely, those on posterior border of segments larger; eighth spinose.

[Described from specimens Hopk. U. S. 11849.]

The larva feeds beneath the bark of the base of dead trees or stumps, later going into the sapwood to construct the pupal cells. It has been found in Quercus and Castenea. The larva opens the mine forming the exit hole through which the adult emerges. Two years are required to complete the development. Range, throughout the eastern United States and Canada. Observations by W. F. Fiske, T. E. Snyder, R. W. Van Horn, and the author.

ROMALEUM sp. (11871)

\section{XLIV}

This larva closely resembles rufulum, but can be readily distinguished by the several deep transverse wrinkles or folds across the hypostoma, while in rufulum the hypostoma is closely wrinkled or finely striate, longitudinally in reference to the head, and the gula is very short, as wide or wider than long. The body texture is thin, the hairs finer, and the ampullae more closely reticulated almost to a degree of tuberculation.

Pupa: Resembles rufulum except that the spines are heavier.

[Described from specimens Hopk. U.S. 11871.]

The larva feeds on the outer thick bark of Quercus prinus and probably other oaks, where a long mine, sometimes 3 feet in length, is excavated through the projecting ridges of bark and tightly packed with granular frass. Before pupation a cell is made between the bark and sapwood, scarring the cambium and causing a subsequent black scar or defect which is not effaced for years after, and which mars many following years of growth. The pupal cell is distinguishable on the surface of the tree, as an elliptical scar, parallel to the trunk, resembling a healed axe cut. Caged larvae have lived three years and have not yet pupated. Mr. W. H. Long, of the Bureau of Plant Industry, United States Department of Agriculture, collected specimens of the larvae and has recorded serious damage to the resulting oak timbers in the Ozark mountains.

The larvae of this insect have been under observation for five years, but not until the summer of 1917 was it possible to secure adults, when the writer, with Mr. H. B. Kirk, cut out a pupa and several adults dead in the pupal cell on June 22, 1917, at Charter Oak, Pa. The adult has not been determined as different from other forms here described, but the writer considers it a good species, probably new, and suggests the name Romaleum cortiphagus.

\section{EUSTROMA VALIDUM LeConte}

Similar to $R$. atomarium, but instead of one ocellus, two very small ones are present, almost indistinet; the process of the palpifer is large, as long as the last joint of the maxillary palpi; this joint is very acute; labrum densely hairy on anterior margin, widest near base; pronotum deeply punctured on anterior half, posteriorly finely, somewhat pinnately striate.

[Deseribed from specimens Hopk. U.s. 10057.]

The larva feeds in dead wood at the base of the tree, excavating large galleries beneath the bark and down into the roots. The pupal cell is made at the end of a long mine in the wood. It has been collected from Prosopis and Parkinsonia in Arizona by M. Chrisman.

\section{ELAPHIDION MUGRONATUM Fabricius}

\section{Pl. VIII, fig. 9; Pl. X, fig. 6; Pl. XV; fig. 4]}

Form robust, elongate, anteriorly depressed; integument tough, shining, rat her thickly covered with long golden hairs.

Head roundly rectangular, depressed; mouth-frame heavily cormeous, dark reddish, bearing a few setae scarcely longer than the antemne; epistoma suddenly and deeply emarginate behind clypeus; mandibles and ventral mouth-parts as in Romaleum; labrum suborbieular, hairs deuse but not longer than its length; antennal joints subequal or last a little shorter than second; ocelli, two, prominent, globular, inclosed by corneous genal shoulder; process of palpifervery prominent. 


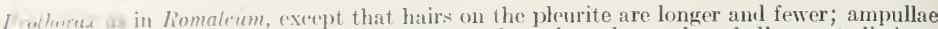
1. Antacesus and having more of a tendency to be tubereulate; pleural dises not distinct, wrmblevt; spiraches broudly ovil to suborbieular, peritreme distinet. Other charafters as in liomule $u m$.

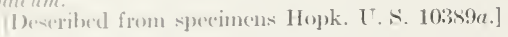

The larva fords in the deal branches of a great variety of hardwoods, mining beneath the bark and deeply scoring the wood, which it enters only to make the pupal coll. This cell enters the wood at right angles to the grain, then sudelenly turns parallel to it. It is opened through the bark by the larva. The life-cyele is normally completed in two years. The first year the larva mines bencath the bark. Range, central and castern United States and Canada. It las been collected from Quercus, Rhus, Morus, Acer, Castanea, Cercis, Populus, Liriodendron, Isimina, Pyrus, and Sassafras. Mr. W. F. Fiske has collected a mumber of larvae from Taxodium in the South. These larvae have smaller spiracles.

\title{
ELAPIIIDION INERME Newman
}

\author{
[Pl. VIII, fig. 11]
}

Form as in mucronatum; body densely covered with long coarse hairs, those c n prothorax very long; head depressed, though not as strongly as mucronatum; epistoma broadly emarginate, hairs very long; labrum sub-orbicular, slightly longer than wide, hairs dense, longer than its length; antemnal joints 1 and 2 subequal, but little longer than wide, the third much longer; otherwise as in mucronatum.

[Described from specimens Hopk. U. S. $10077 f$ collected by H. P. Loding.]

This is a southern species recorded only from the branches of orange trees (Citrus). The work is similar to that of E. mucronatum.

\section{ELAPHIDION VILLOSUM Fabricius}

\author{
[Pl. XXI, fig. 3]
}

Immediately recognizable by the very long, lemon-yellow hairs, especially on prothorax, these being as long as the pronotum; short subulate hairs on epipleurum and alar area of prothorax absent. Head broadly oval in cross section; epistoma very shallowly emarginate, bearing a number of long hairs; labrum orbicular, hairs on middle longer than labrum itself; genal shoulder enclosing ocelli less abruptly. Posterior area of pronotum simply, irregularly, coarsely striate; ampullae sub-tuberculate; spiracles broadly oval to orbicular, peritreme indistinct.

[Described from specimens Hopk. U. S. 9781.]

The larva attacks the smaller branches of a great variety of hardwood trees. It burrows down the centre of the stem until nearly mature, when it cuts off the branches from the inside, leaving a thin shell of bark, which later breaks. Rarely are holes made along the mines to exude frass. Pupation occurs between two plugs of frass, in the late fall or early spring. The life cycle is completed in one year. This species often becomes of economic importance and is abundantly cited in literature.

It is sometimes reared from branches which are dead and in this case does not girdle them. This may be a different species, as some of the larvae show variations from the form described.

\section{ELAPHIDION INCERTUM Newman}

Similar to mucronatum but readily distinguished by the greater degree of hairiness, the hairs being very fine; head oval in cross-section, but not so markedly as in villosum; labrum, transversely oval, very fincly ciliate; hairs about epistoma very short, much shorter than antennae while in mucronatum they are about as long as antennae; epistoma thickened, broadly and rather deeply curved, wrinkled. Spiracles small, nearly orbicular, some abdominal ones but little larger than ocellus.

Pupa: Head, pronotum, mesonotum, and metanotum unarmed; a transverse row of acute spines oll posterior border of first few abdominal segments, becoming arranged in an oval man. ner on posterior ones; several spines on eighth; a median longitudinal stripe of very fine pubes. cence on first seven.

[Described from specimens Hobk. T. S. $9791 a$ and 10320. 
The larvae here described have been found only in the outer bark of Morus, where an irregular contorted gallery is excavated, sometimes scoring the cambium. Observations by H. B. Kirk, A. B. Champlain, and the author at Harrisburg, Pa. A larger, more robust form, having larger spiracles and finer body-hairs, is found beneath the bark of dead, somewhat decaying hickories. [Hopk. U. S. 9791d.]

\section{ELAPIHIDION ARIZONENSE Casey}

Similar to E. mucronatum but more robust; striations on posterior pronotum finer; epistoma nearly straight; labrum semi-circular, usually much wider than long, widest at base; first and second joints of antennae subequal; process of palpifer longer than last joint of maxillary palpus; ocelli small; ampullae coarsely reticulate to sub-tuberculate; spiracles small, oval, peritreme indistinct.

[Deseribed from specimens Hopk. U.S. 10353c and 10065c.]

This is a southwestern species working, much as E. mucronatum, beneath the bark of dead Salix, Populus, and less frequently Quercus. It is usually found in somewhat decayed wood associated with a species of Acanthoderes. Collected by M. Chrisman and Creo. Hofer in Arizona.

\section{ELAPHIDION sp. $12283 i$}

This species very closely resembles $E$. arizonense. The body hairs are silky, short, and less closely set, and the striations on the posterior area, of the pronotum are deeper and more closely set; epistoma broadly emarginate; labrum semi-circular, wider than long, glabrous in middle; second joint of antennae the longest; process of palpifer very large, as also that of first maxillary joint; ampullae somewhat tuberculate along lateral impression; pleural dises rather distinct on first and second segments; spiracles oval, peritreme thin.

[Described from specimens Hopk. L.... 12283i.]

These larvae were collected from dead Juglans branches in Arizona by M. Chrisman. The work is very similar to that of E. mucronatum.

Although this larva in many respects closely resembles that of $E$. arizonense, in other characters, chiefly the prominent pleural dises, it suggests the following undetermined species.

\section{ELAPHIDION sp. $10500 a$}

Form as in E. villosum; integument firm, shining; body hairs fine, whitish; head somewhat ova in cross section; epistoma shallowly but suddenly emarginate at centre; labrum broadly ova to sub-orbicular, little wider than long, covered with long hairs; first antemnal joint tran sverse shorter than second, which is about as long as wide; last joint of maxillary palpi equal to second slightly shorter than last labial; process of palpifer minute. Posterior area of pronotum entbossed, very smooth and shining, except for a few large punctures, the posterior ones extended into striae; pleural dises finely granulate, with a deep pore on first, seeond and third segments; abdominal spiracles minute, oval, but little larger than ocellus.

[Described from specimens Hopk. U.s. 10500a.]

The larva feeds in the dead dry stems of Yucca.

It does not girdle branches. It has been collected in Arizona by M. Chrisman.

\section{ELAPHIDION sp. 1005.)}

Distinguished from $10500 a$ as follows: Labrum orbicular; first and second antennal joint subequal, slightly wider than long; epistoma broadly curved, not suddenly emarginate.

[Described from specimens Hopk. [T. s. 10055.]

These larvae were collected in the stems of Rhus in Arizona by W. D. Edmonston. They do not girdle the branches.

\section{ELAPIIDION sp. $10961 d$}

[Pl. VIII, fig. 10]

Resembles $10500 a$, but the form is more robust and body hairs very coarse; head more depressed; epistoma very abruptly and deeply emarginate behind clypeus; labrum thin suborbicular, though wider behind; second joint of antennae slightly longer than wide; palpifer process minute; pleural dises finely granulate with a deep pore on first, second and third abdominal segments; spiracles sub-orbicular small.

[Described from specimens Hopk. U.s., 10961d.] 
This species feeds in the small hranches of the Chilicote bean (Erythrina comalloides) in Arizonat, hut does not girdle the branches. The specimens were collected hy (ieo. Hofer.

\title{
Tribe IIETEROSPINI
}

These larvae, including the genus Stenosphenus and Elaphidion alienum, are regarded as a listinct group showing a well graded transition from the true specics of Elaphidion, especially those forms with a deep pleural disc (E. 10500a, etc.) to the species of Elaphidion having one ocellus (E.tenue, etc.). They may le recognized as follows:

()ne liarge occllus, enclosed by a slightly shouldered (corneous or non-corneous) gena; process of palpifer large and distinet; prothorax depressed, ventral region very broad; posterior pronotum regularly striate, no median suture; ventro-lateral suture absent or faintly impressed; stcrncllar fold somewhat fused into epipleurum; inetanotum bearing one transverse and several short oblique impressions; legs four-jointed, slender; pleural dises a deep pore, finely granulate or faintly striate; ampullae alutaccous, shining, with two transverse sutures, the posterior often indistinet.

\section{KEY TO THE GENERA OF HETEROSPINI}

Gena corneous; pleural dises having a small pore ...................... alienum

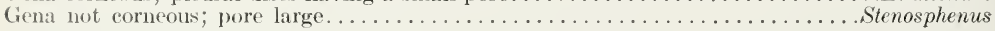

\section{ELAPHIDION ALIENUM LeConte}

\section{[Pl. XXI, fig. 8; Pl. XV, fig. 5]}

This larva ean only be distinguished from Stenosphenus by the smaller pore and larger granulate area of the pleural dises; the striate area of the pronotum protrudes anteriorly along a median line as in the true species of Elaphidion; the ventro-lateral sutures are represented as a mere notch (as in Elahpidion), and the eusternal glabrous spots are distinctly separated.

Form rather robust; integument tough, shining, thickly covered with light eastaneous hairs; labrum transversely oval; ocellus enclosed by a dark chitinization of gena; pronotal striae slightly oblique and with a tendency to reticulation; ampullae alutaceous; spiracles broadly oval, middle abdominal ones not larger than ocellus. Otherwise as in Stenosphenus.

[Deseribed from speeimens Hopk. U.S. 12602 and 12612b.]

The larval work cannot be distinguished from that of Stenosphenus. It has been collected from Prosopis in Arizona by M. Chrisman.

\section{STENOSPHENUS NOTATUS Olivier}

\author{
[Pl. XXI, fig. 6; Pl. XV, fig. S]
}

Form elongate, slightly tapering, thorax depressed; integument tough, shining, rather thickly covered with long, fine, lemon-coloured hairs.

Head roundly rectangular, tapering little in front; mouth-frame not heavily corneous, bearing long slender setae; labrum fleshy, sub-orbicularly transverse; mandible narrow at apex, basal piece slightly lighter and about one-third as wide as distal, latter piceous with sulcus on outer face; first and second antennal joints subequal, third shorter, slender; ocellus large, globular, somewhat enveloped by non-corneous gena; mentum very hairy; last joint of maxillary palpus slightly longer than second, about equal to last labial; process of palpifer and that of first joint of maxillary plapi large, distinet.

Prothorax rather clepressed, narrowly rectangular; pronotum less than twice as wide as long, median area deeply punctured and hairy, posterior embossed, finely and regularly striate with a fel seattered punetures, no mediam suture; sternum broad, hairy; mesonotum marked by a single transverse impression; no ventro-lateral sutures; eusternal plates contiguous, glabrous; sternellar fold somewhat fused into epipleurum at extremities. Legs four-jointed, quite long.

Abdomen: Ampullae slightly protuberant and narrow, dorsal alutaceous to coarsely granulate, markerl by two lateral and two bow-shaped transverse impressions and a deep median furrow. Pleural dise a deep pore on second, third, fourth, and fifth segments. Spiracles small, oval, peritreme thin.

Pupa: A few seattered, fine hairs on dise and a few setiferous points on posterior margin of pronotum; a few ninute points on mesonotum; first seven abdominal terga bearing a transverse row of small chitinous points, largest on first few segments; eighth bearing several minute
points.

[Described from specimens Craig. 335a.] 
The eggs are laid in the spring and early summer in crevices of the bark, and from these places of oviposition the larval mines subsequently radiate in all directions beneath the bark. The sapwood is deeply scored until the matured larva bores directly into the wood at right angles to the axis, then suddenly turns parallel to the grain, making a sharply curved and characteristic pupal cell. Pupation takes place in the late summer. The adults hibernate in the cell. It has only been taken from hickory (Hicoria) in the central and eastern United States.

\section{STENOSPHENUS sp.}

Very similar to notatus, but slightly more hairy, these hairs light castaneous; labrum transversely oval; striations on posterior pronotum finer, a row of faint lenticular impressions along posterior edge.

[Described from specimens Hopk. U. S. 10356.]

Pupa: Similar to that of notatus, but having a few short hairs on the mesonotum and more points on the metanotum.

This is a southwestern species collected only from Juglans in Arizona by M. Chrisman. The habits are similar to those of S. notatus.

\section{ELAPHIDION TENUE LeConte, ELAPHIDION spp, and ANEFLUS}

The following larvae are considered generically distinct from the other species of Elaphidion and possibly even of higher rank as they are here placed. These forms show the extreme specialization of the twig-girdling habits peculiar to certain species of Elaphidion. The larvae are likewise specialized and approach those of the group Stenaspis, though the transition is probably not clirect. They can be recognized as follows:

Form very elongate, cylindric; body very hairy; head oval in cross-section; one large ocellus; gena not shouldered and bearing long curved setae; process of palpifer distinct, rather large; prothorax quadrate, ventral region very broad; posterior pronotum embossed, finely and regularly striate, anteriorly densely and longly haired, no median suture; latero-ventral suture absent; eusternal spots very small, fused; sternellar fold somewhat fused into epipleurum, not passing spiracles; metanotum bearing a transverse and several accessory impressions; legs fourjointed, long, slender; ampullae strongly protuberant, small having two lateral, one transverse, and a median impression, all very deep; intersegmental skin very long; pleural dises somewhat variable, usually striate, with a deep pore.

\section{KEY TO THE SPECIES OF ELAPHIDION HAVING ONE OCELLLS, AND TO ANEFLUS}

Ninth abdominal segment normal.

Anterior edge of hypostoma smooth or wrinkled.

First and second antennal joints subequal.

Gena bearing two or three long setae; spiracles small

Gena bearing six long setae in a row; spiracles larger.

Second joint of antennae much longer than first; pleural dises conspicuous.

Elaphidion sp. $9903 \mathrm{~s}$ E. subpubescens dises conspicuous.

Ninth abdominal segment chitinized and spiny

E. unicolor Ineflus

A gradual trarsition is shown from the true species of Elaphion to this group, through several forms. E. alienum has one ocellus which is enclosed, as in most of the species of Elaphidion, by the corneous gena. Stenosphenus has the gena less shouldered and not so corneous. These species have a still more receding gena. Some of the species of Elaphidion with two ocelli $(10500 a)$ have a deep pore in the pleural dises, which is true also of Stenosphems and E. tenue. The hairs of the gena, likewise, gradually become more setose, from forms such as E. villosum through Stenosphenus to $E$. subpubescens. The true species of Elaphidion have x-shaped impressions on the metarotum; Stenosphenus has a transverse impression with a slight wrinkle behind it, but these species have trar sverse and several other deep impres:iors. Again, the ampullae have two transverse impressions in the true speceis of Elaphidion; the posterior one is incomplete in E. alienum, and is absent in the forms like tenue. In Steno- 
sphenu the last rentral ampulla is narrow, transverse, and striate, it is still nore strongly striato in $E$. subpubescens, and all of the ventral ones are striate 111 E.. sp, $9 ! 903$ s.

This gradual transition in anatomical structure is likewise correlated with :t sperialization in haloits. Elaphidion villosum illustrates the best example of the rirlling labit in the preceding group. It simply euts the twigs and feeds in the leas portion and never extrudes the frass. The forms of the present group, however, not only eut off the branch but do so after they have burrowed farther down into the living tissue. Along the burrow a series of small holes is marle, through which the frass is extrucled, keeping the mine entirely open, often for a listance of 3 feet. These larvae are extremely active and by means of the very protuberant ampullae can move through the twig with marvellous rapidity. Several forms cut off the abandoned part of the twig by very complicated incisions. E. subpubescens, when in small plants from one-half to one inch in dianeter, usually goes down to the base of the ground before completing its mine. Pupation takes place between two wads of frass, somewhere in the more recently excavated portion of the twig.

In interesting parallel between these and some genera of Lamiinae of like habits is to be found in anatomical structure. It can be best illustrated by Oberea, although also by Hippopsis and Ataxia. The form of the larva, even to the development of the ampullae, the striations of its lobes, and the shape of the thoracie segments, is similarly developed in both.

Recently several peculiar larvae have been associated with adult remains of Aneflus. These larvae agree in all eseential structural characteristics with the species of Elaphidion here discussed. The tenth abdominal segment is enlarged, strongly chitinized, and beset with numerous short spines, the ampullae are tuberculate or nearly so, but otherwise they are structurally similar to temue and subpubescens-like forms.

Except for the fact that they bore in larger branches and even in small trees, they are not biologically different.

\section{ELAPHIDION sp. $9901 q$ and $9903 s$}

\section{[Pl. XLII, fig 5]}

Form very elongate, slender; integument thin, rather dull, very thickly eovered with long, whitish hairs, becoming golden on prothorax; living larvae a deep orange colour.

Ilead sub-orbicular, thick, oval in cross-section; mouth-frame corneous, light brown; clypeus minute, labrum orbicular, entirely hairy; mandibles short, basal piece about one-third of distal, light brown, latter broad, dull black; first and second antennal joints subequal, about as long as wide, third shorter; ocellus large, prominent, contiguous with base of antennae, not enveloped by gena, which bears several very long setae, curving anteriorly, and one above antennae; last joint of maxillary palpi equal to second, shorter than last labial; process of plapifer distinct, rather large; anterior edge of hypostoma protuberant, carinate, wrinkled.

Proth rax sub-quadrate, covered with very long hairs; pronotum anteriorly uniform hairy, with prominent, dark ochraceous tergal plates, posterior area embossed, white, shining, very regularly and deeply striate, no median suture; sternum uniformly hairy; eusternal glabrous spots very small; sternellar fold slightly fused at extremities, not passing spiracles. Metanotum bearing one transverse and several short oblique impressions; legs four-jointed, very long and slender.

Ibrdomen: Segments much distended, space between ampullae twice as great as ampullar wilth, ampullae very abruptly protuberant, dull granulate, marked by two very short lateral impressions, one transverse and a longitudinal one behind the transverse, impressions all very deep, ventrally the ampullar area behind the transverse impression is finely striate. Pleural dise a rather deep pore, semicircular, dull granulate. Spiracles of abdomen not much larger than ocellus, sub-orbicular.

[Described from specimens Hopk. U. S. 9901 $q$ and 9903s.]

The larva girdles the living branches of Thurberia. It cuts off successive sections as it bores farther down in the wood. This cut is v-shaped on the upper part of the branch and inverted on the lower. A long series of holes in a straight row is made to the surface. These specimens are collected by H. S. Barber in Arizona. 


\section{ELAPIIIDION SUBPUBESCENS LeConte}

[Pl. I, fig. 11; Pl. XXI, fig. 5; Pl. XVIII, fig. 3; Pl. XV, figs. 9, 10 and 14;

Pl. XXVI, fig. 4; Pl. XLII.]

Similar in form and integument to E. 9903s, readily distinguished by the much larger suborbicular spiracles and by the fact that the gena bears a straight row of six very long, closely set setae, curved forward; the front bears many shorter setae; the epistoma is suddenly emarginate in the middle; the striations on the posterior area of the pronotum are finer; the pleural dises are inconspicuous, and the ventral ampullae, except the last, are divided by a median longitudinal smooth area.

Pupa. Similar to tenue, but the spines on the abdomen are heavier and a few are present on the eighth segment.

[Described from specimens Hopk. U. S. 9195k.]

The habits are similar to those of the preceding species, but this species attacks small seedlings from one-half to one inch in diameter. Entering the top it successively cuts off sections about a foot in length, often going below the surface of the ground to pupate. The incision across the branch is nearly transverse. The life cycle is completed in one year. It has been collected in Quercus and Castanea. Range, southern United States. Observations by H. B. Kirk and the author.

\section{ELAPIIIDION TENUE LeConte}

\section{[Pl. X, fig. 3]}

Scarcely distinguishable from $9903 s$, except for the large orbicular to angularly oval, reddish brown spiracles; epistoma only roughened; hairs lighter in colour and posterior area of pronotum more regularly striate, resembling lines of copper engraving; second joint of antennae twice as long as first; only last ventral ampulla striate; pleural disc distinet and radially striate, with a deep pore.

Pupa: Head, pronotum, mesonotum, and metanotum glabrous; posterior half of aldominal terga bearing very small chitinous-tipped spines (projecting in all directions), arranged in four more or less regular groups of about the same size on all segments, but few on first and second and none on eighth.

[Described from specimens Hopk. U.S. 10519a, 1266sb, 12634a, 12614t, and 12633.]

This species has only been taken girdling oak branches (Quercus). The larvae burrow down the branch until reaching a diameter of three-fourths to one and onc-half inch, where a single incision is made. This is a spiral cut from the pith outwark, as in E. villosum. Holes are made at irregular intervals for extruding frass, but not so numerous as in the case of other species. The specimens have been collected in Arizona by M. Chrisman.

\section{ELAPIIIDION UNICOLOUR Randall}

[Pl. VII, fig. 12]

Form elongate, slender; integument thick, dull, finely granulate, sparsely covered with long, fine, whitish hairs; colour white.

Head and mandibles similar to those of E. subpubescens; first and second joints of antennae equal; a long seta above antennae and one behind ocellus; basal joint of maxillary palpi transverse, beadlike, second and third subequal, third shorter than last labial; anterior edge of hypostoma protuberant, regularly carinate; thorax and abdomen as subpubescens, except that the ampullae are less protuberant, and the ventral ampullae are not so distinctly divided by longitudinal, shallow impressions. Pleural dises distinet on first and second abdominal segments. Spiracles about size of ocellus, orbicular.

[Described from specimens Hopk. Uं.s. $97 \mathrm{~s} 0 \mathrm{k}$ and $9193 \mathrm{l}$.]

Habits similar to those of E. subpubescens, but the incision for severing the branches is more oblique. Range, eastern United States. Observations by the author.

\section{ANEFLUS sp. (PROTENSUS LeConte)}

Form elongate, cylindrical; integument tough, shining, clothed with stiff reddish hairs.

Head subtrapezoidal; anterior margin bearing many short stiff hairs; mouth-frame heavily chitinized, very dark reddish to piceous; clypeus thick, subrectangular, beset with stiff reddish hairs; epistoma broadly emarginate; mandible entirely black, shining, basal piece about onethird length of distal, latter with a fovea on outer face; ocellus prominent, contiguous to anten- 
nim and semewhat enclesed ly gena; antemnae slender, first joint longest, globular, last very slender"; genat slightly shouldered. Ventral mouth-parts thin and more chitinized than usual; jumi of unxillary palpi grachally shorter, last slender; process of palpifer minute; gula indistiutet.

Prothornx cumdrate; postcrior portion of alar and lateral areas denscly and coarsely haired; four prominent tergal plates; pronotum reetangular and little wider than long, posteriorly cmbessel, white, lincly ruglose in longitudinal lines, no median suture; sternum hairy except for glabrous, rugulese, eusternal area; stemellar fold not passing spiraeles; no trace of ventrolitcrial suture. Ifesonotum and metanotum rugulose, shining, former with x-impressions, latter witly a transverse impression and inverted $\mathrm{v}$ belind (seutellum distinet). Legs fourjointed, exchsive of tarsus a little longer than maxillary palpi, tarsus a slender spine.

Ablomen: Ampullac flat, shining, finely rugulose, dorsal having two transverse impressions, the posterior incomplete at iniddle; tenth segment regularly and sparsely beset with ereet, aeute, comical points, anal lobe protruding; pleural dises eireular, dull, granulate, distinet on first, second, third, and fourth segments, faintest on first. Spiraele quite large, narrowly oval, petrene thick, reddlish.

[Deseribed from specimens Ilopk. U. s. 10082s.]

A number of larvae of this and probably several allied species are represented in the U.S. Ferest Insect Collection.

All specimens have been collected from mesquite (Prosopis) trees. The larvae start mining in the smaller branches hollowing out the stems. As they increase in size, larger branches and finally the main trunk are attacked and often excavated to the surface of the ground. The pupal cell is constructed in the wood near the end of the larval mine; the exit hole being made by the larva. The larval mine is kept free of frass, which is extruded through small holes along the stem. The interior of this mine is always black and stained. Adults and pupa were taken in the wood, June, 1918. Observations from notes and specimens of G. Hofer and M. Chrisman and the author.

\section{Tribe IBIDIONINI}

\section{The following larvae may be characterized as follows:}

Two ocelli enelosed by a shouldered gena; a single transverse impression on the metanotum; process of palpifer distinet, rather large; posterior area of pronotum striate, no median suture; ventro-lateral suture not impressed; sternellar fold distinct at extremities; pleural dise finely granulate on two or three segments.

These larvae might be confused with those of Elaphidion, to which they are no doubt related, but can be easily distinguished by the pleural discs and transverse instead of $\mathrm{x}$-shaped suture of metanotum.

\section{KEY TO THE SPECIES OF IBIDIONINI}

Mandibles normal, short; labrum transverse.

Anpullae granulate......................... Heterachthes quadrimaculatus

Ampullae alutaceous. .............. Heterachthes ebenus

Heterachthes aenolus

Mandible ntore slender; basal piece forming a distinet shoulder; labrum suborbicular; ampullae

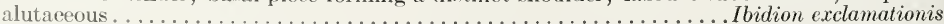

\section{HETERACHTHES QUADRIMACULATUS Newman}

\section{[Pl. XVIII, fig. 4]}

Form elongate, slender, slightly tapering; integument thin, shining, sparsely eovered with fine whitish hairs.

Head subreetangular, slightly tapering anteriorly; mouth-frame corneous, castaneous; clypeus and labrum narrow, fleshy, latter transversely oval, widest behind; mandibles short, basal pieee about one-third length of distal, the latter piceous, shining; last joint of antennae shorter than sccond, about equal to globular first; ocelli two, enelosed by eorneous shoulder of gena; ventral mouth-parts rather fleshy, last joint of maxillary palpi longer than seeond, shorter than last labial; process of palpifer, large, distinct.

Prothorax slightly depressed; pronotum little wider than long, posteriorly shining, finely and regularly striate, anteriorly sparsely hairy, no median suture; sternum narrowly transverse; ventro-lateral suture not impressed; eusternal spots eontiguous, glabrous, shining, having a few short striae; sternellar fold distinet at extremities. Metanotum having a single transverse impression. Legs short, three-jointed. 
Abdomen: Ampullae broad, rather flat, coarsely granulate, dorsal ampullae marked by curved transverse impression, meeting two short lateral ones. Pleural dises finely granulate on second, third,and fourth abdominal segments. Spiracles on abdomen little larger than ocellus, broadly oval, peritreme thin.

[Described from specimens Hopk. U, S. $9784 b^{1}$ and $11845 c$.]

The larva extends the greater part of its mine in the wood proper, where long tunnels are made parallel to the grain. A sudden outward turn of one of these burrows serves as the pupal cell. Its life cycle is normally completed in one year. Range, eastern United States. Observations by W. F. Fiske, A. B. Champlain and the author.

\section{HETERACHTHES AENOLUS Bates}

Distinguished from quadrimaculatus by the coarse striae of the pronotum and the strongly alutaceous ampullae.

Described from a single poor specimen in the United States National Museum collection, reared from grapevines ( T itis) in northern Mexico.

\section{HETERACHTHES EBENUS Newman}

This species can be distinguished from $H$. quadrimaculatus by the coarser striae of the pronotum (each striae being separated from the other by four or five times its width), which posteriorly ent in a dull, granulate area; prosternal plates shining and sparsely rugulose; the ampullae more finely granulate; gena somewhat corneous; antennae thick, second joint twice or more length of first; pleural dises distinct on five abdominal segments.

[Described from specimens Hopk. U.S. 10082a.]

Collected by A. B. Champlain in the branches of dead Pinus rigida on Long Island, N.Y. The work resembled that of $H$. quadrimaculatus.

\section{IBIDION EXGLAMATIONUS Thomson}

\section{Distinguished from Heterachthes quadrimaculatus as follows:}

Labrum elongately orbicular, widest in front; mandibles more salient, basal piece about one-fourth length of distal, set off as an abrupt shoulder; process of palpifer shorter than last joint of maxillary palpi; striae of pronotum coarser and more deeply impressed, extending slightly forward in middle; ampullae strongly alutaceous, shining.

[Described from specimens Hopk. U. S. 6151a.]

The larva was collected by Mr. H. S. Barber in the wood of Mimosa at Brownsville, Tex.

\section{Trine STENASPINI}

The following species, though placed in several distinct tribes as adults, must be considered in a single group as larvae. In fact, in those genera in which several species have been studied it is usually impossible to formulate generic characterizations. They illustrate as a group the most extreme modification or absence of those structures characterizing the lower groups and are placed at the end of the series of the Cerambycinae.

They may be easily recognized as the only larvae of this subfamily having the median and lateral pronotal and the ventro-lateral sutures impressed for the entire length of the prothorix; also in having the two distinct presternal yellowish plates on the prothorax. They can be further characterized as elongate, hairy forms, usually of a yellowish colour; head trapezoidal; gena shouldered, enclosing a large ocellus contiguous with antennae; genal bristles wanting; process of palpifer distinet (except in Crossidius); prothorax having eight or six (lateral wanting) yellowish plates on anterior margin; pronotum anteriorly punctured and densely hairy; posterior area somewhat raised, white, striate; eusternum never distinet, and glabrous spots never circular; sternellar fold distinet at extremities but not passing spiracles; mesonotum having the seutellum distinet; metanotum with a single transverse impression; legs four-jointed, very long; ampullae projecting, oval, granulate, alutaceous or tubereulate, the dorsal with two lateral and two transverse impressions, though the latter is often wanting, and a broad, shallow, longitudinal furrow; pleural dises usually indistinet, obliterated by pleural cuberele, wrinkled rugulose to granulate, pore never very deep.

The pupae are generally distingusiled by an excessive laainess and by the fact that the mesonotum projects over the metanotum in a more or less triangular process. 
These species are typical wood feeders. The larvae bore in the wood a meat deal more than beneath the bark. Some species oceasionally attack dry setsonerl woud on which no bark is present (chion). The frass is rather coarse, gramular. and most of it is extruled through one or more holes made as the larval enters the wood from the bark. These mines within the wood are large, straight and more or less parallel to the grain; before pupation the exuctation hole (through which the frass is pushed out) is plugged by a protruding wad of frass. 'This is very characteristic for most of the species. The adult gnaws allay this plug to emerge. Correlated with the open larval mines is the elongate form of the larva and well developed ampullac. One species girdles branches (Purpuricenus axillaris), and the ampullae tend to be striate as in the species of Elaphidion having one ocellus (tenue, etc.) and Oberea of the Laminae. Crossidius pulchclla is a root feeder in shrubby plants and shows the greatest departure from this group.

\section{KEX TO THE SPECIES OF STENASPINI}

Irothorax having eight yellowish plates around anterior margin; ampullae dull, granulate.

Mandible bearing a faint carina on outer face.

Anterior margin of hypostoma roughened; last ventral ampulla granulate.......... Chion

Anterior margin of hypostoma carinate, wrinkled; last ventral ampulla striate.. Purpuricenus

Mandible with a sulcus on outer face; process of palpifer indistinct... Crossidius (pulchellus)

Prothorax having only six plates, lateral plates lacking; ampullae variable.

Prestcrual plates transversely rectangular, narrowly separated; anterior margin of

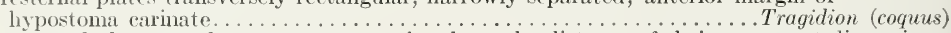

Presternal plates nearly square, separated at least the distance of their narrowest dimension.

Interior margin of hypostoma longitudinally striate or carinate.

Carina short, not so regular; ampullae alutaceous.................taleptus (batesi)

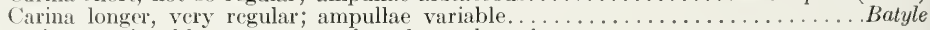

Anterior margin of hypostoma roughened or tuberculate.

Margin smooth, areuate; ampullae tubereulate...

Nargin bearing four tubercules; ampullae alutaceous.

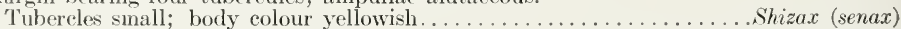

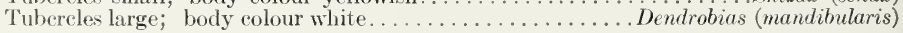

\section{GIION GINC'TUS Drury}

\section{[Pl. VIII, fig. 14; PI. XXVIII, fig. 5]}

Body elongate, slender, subcylindric; integument firm and tough, somewhat shining, densely covered with long, fine, castaneous hairs; body in life a lemon-yellow to orange colour.

Ilead subquadrate, widest behind and constricted above middle; mouth-frame firmly corncous, dark reddish brown; epistoma suddenly emarginate in middle; anterior edges of hypostoma sub-tuberculate; labrum elongately orbicular, entirely covered with long, dense, castaneous hairs; mandible piccous, shining, basal piece reddish, about one-third length of distal, a fine carina on outer face; antennae long, first and third joints subequal, second slightly longer; one large distinet ocellus contiguous to base of antennae and enclosed by shouldered gena, latter not setose; joints of palpi all subequal; process of palpifer long, that on first maxillary joint, distinct.

Prothorax transversely rectangular, about twice as wide as long; anterior margin nearing eight transverse ochraccous plates, four tergal, two presternal, and two lateral, the two presternal ones transverse, siightly separated; pronotum anteriorly regularly punctured, bearing dense, fine hairs, posteriorly shining, striate, median suture entirely impressed, deepest behind; sternum hairy; eusternal spots separated, triangular, smooth, shining. Mesonotum having the seutellum distinct; metanotum with a transverse impression. Legs four-jointed, very long and slender.

Abdomen elongate, very slightly compressed; ampullae prominent, oval, widely separated, granulate, granules flattened, faintly shining, dorsal ampullae marked by two lateral and two transverse impressions, ventral with one transverse. Pleural dise rugose, not distinct. Spiracles very broadly oval, large, peritreme thin.

Pupa: Pronotum beset with dense short hairs except on posterior half of dises; mesonotum and metanotum bearing a few finer ones; abdominal terga beset with short acute asperities projecting posteriorly, those on fourth, fifth, and sixth segments arranged more or less in an oval manner, with two groups of three each in center; seventh with six or eight larger recurved spines on posterior margin; a few small points on eighth; lateral region of abdominal terga hairy.

The larva attacks the rather dry, dead branches or larger limbs of Hicoria, Quercus, Juglans, and Castanea, excavating the mines beneath the bark but 
principally in the wood proper. The latter part of the mine is sometimes 2 feet long. Much frass is extruded and the greater part of the burrow in the wood is open. Before pupation a large protruding wad of frass is placed in the exudation hole. Normally two years are required to complete the life cycle, but this is sometimes extended to three. The adult transforms in the fall and hibernates in the cell, or pupation takes place in the spring. The eggs have been found laid on dry, barkless branches in checks of the wood.

The habits and larval characters of the western variety are similar. It has been collected from Quercus and Parkinsonia by J. L. Webb and M. Chrisman in Arizona.

\section{PUPURICENUS AXILLARIS Haldeman}

Form elongate, slender; integument shining; mandible with a very faint carina on outer face; basal joint of antennae short very; joints of palpi obliquely truncate at tip; process of palpifer minute; anterior edge of hypostoma nearly straight, finely wrinkled; presternal plates rectangular, separated by a distance equal to their narrowest dimension; eusternal plates rectangular, contiguous; lateral ones less distinct than in Chion; posterior area of pronotum coarsely and deeply striate; mesonotum and metanotum alutaceous, shining; ampullae dull, finely granulate to reticulate, not divided. Abdomen less hairy than the other species. Last ventral ampulle striate behind. Spiracles broadly oval, sunken, middle abdominal ones about as large as spiracles.

[Described from specimens labelled "State College Penn. Ap. 10, 1912. Hickory Twigs."]

This larva is the only species in the tribe in which the habit of girdling has been developed. The work is similar to that of $E$. villosum, but larger branches often 2 inches in diameter are severed. It rarely euts the branch more than once and this incision is of a spiral form from the centre outward. Frequently it is found in branches which it does not girdle. Much of the frass is exuded, but only from one or two holes. The life cycle is completed in one year. It has been collected in Hicoria and Quercus. Observations by A. B. Champlain and the author. Range, eastern United States.

\section{PURPURICENUS HUMERALIS Fabricius}

Distinguished from axillaris by the broadly oval and darker spiracles, the smallest being larger than the ocellus; the presternal plates are nearly contiguous, and the ampullae are more finely granulate.

[Described from Specimens Hopk. L. S. 11s $45 v$.]

Habits similar to those of Chion cinctus but the larval mines are less extensive. Pupation takes place in the early summer. It has been taken in Quercus, Betula, and Castanea. Range, eastern United States and Canada. Observations by A. B. Champlain and the author.

\section{TRAGIDION ARMATUM LeConte}

\section{[Pl. XXVII, fig. 3]}

Form elongate, subcylindric, robust; integument firm, yollowish tinged, shining, densely covered with long, fine, light castaneous hairs.

Head as in Chion, except that the outer face of the mandible has a suleus; labrum widest behind, hairs sparser; ocellus smaller, more projecting, beadlike; anterior edge of hypostoma aretuate, somewhat protruding, first joint of antennae shortest.

Prothorax quadrate; lateral ochraceous plates wanting, presternal oval, separated about their width; sternum entirely hairy, no eusternal glabrous spot; posterior area of pronotum smooth and shining except for a slight irregular tendency of hind margin to be striate; ampullae strongly tubereulate; spiracles narrowly oval, peritreme thin.

[Described from specimens Hopk. L. S. 9901l.]

The larva makes extensive mines in the dry stems of Yucca. The habits are typical of the group. Collected by M. Chrisman and H. S. Barber in Arizona. 
TRAGIDION GOQUUS Linnaeus

Form clongate, rather slender; anterior elges of lypostoma finely carinate and considerably protrucling at edge of gula; mandilse having a sulcus on outer face; labrum elongate, tapering anteriorly theugh broadly rounded; first joint of antennae shortest, transverse; posterior area of mothorax strongly cinlossed, regularly coarsely striate to more fincly and pinnately so lwhind; lateral plates absent; presternal plates transverse, nearly contiguous; eusternal glabrons spots triangular, scparated. Mesonotum and metanotum dull, granulate; ampullae alutaecous to extremely fincly subtubereulate, distinctly divided in middle. Spiracles broadly oval, large.

\section{[1)escribed from specimens Ilopk. I'. S. 12681.]}

These larvae have been collected in the dead branches of Quercus by 1. B. ('hamplain in Colorado. The habits are similar to those of Purpuricenus humeralis.

TRAGIDION FULVIPENNE Say.

several specimens have been reared from Alnus and Quercus collected by 1. 33. Champlain in Colorado and C. Hofer in Arizona. From the larval skins it eamnot be distinguished from coquus.

\section{METALEPTUS BATESI Horn}

\section{[Pl. I, fig. S; Pl. X, fig. 1]}

Form nore robust; anterior edge of hypostoma nearly straight, thick and finely carinate. Ochraceous tergal plates on prothorax very conspicuous, presternal ones transverse but separated the distance of their narrowest dimension; eusternal glabrous spots triangular, separated, very smooth and shining; striae of posterior area of prothorax very fine and lightly impressed, a group of deep punctures on anterior margin (of this area) on each side. Mesonotum and metanot um shining; ampullae very finely alutaccous, shining, ventral only divided. Spiracles small, oval, middle abdominal searcely larger then occllus, peritreme thin.

[Described from specimens Hopk. U.S. 12681 $a$ and 10366c.]

With the exception of one record from Acacia, the larva has been collected only in the dry dead branches of Quercus. The work in all respects resembles that of Chion, though the mines are not so extensive. Pupation occurs in the fall and the adults hibernate in the cells. Collected by M. Chrisman in Arizona.

\section{SHIZAX SENAX LeConte}

Distinguished from Metaleptus batesi by the fact that the anterior edge of the hypostoma is vory thin, wrinkled at the extremities and having one or two tubercles on each side of the gula. Striae of posterior area of pronotum are irregular or slightly sinuous. Ampullae more coarsely alutaccous and not divided.

Pupa. Two groups of hairs on dise of pronotum and a few on posterior and anterior angles; more slender hairs sparsely distributed over mesonotum and metanotum; a transverse band of attenuated, chitinous spines no posterior border of each abdominal tergum, each spine bearing a long hair; a few spines on anterior portion of fifth, sixth, and seventh, the latter uneurved, those on posterior margin of seventh very long; a few short points on eighth.

[Described from specimens Hopk. U.S. 12292 ${ }^{1}$ and 12602.]

The larva has been reared from Prosopis, Thurberia, Zizyphus, and Covilla. In habits it is similar to Metaleptus batesi, but mines more extensively beneath the bark. Specimens collected from Arizona by M. Chrisman, G. Hofer, and H. A. Barber. Mr. Hofer notes that the eggs are covered as in many bupresteids.

\section{BAT YLE SUTURALIS Say.}

A small species of very shining texture; buceal margin scarcely chitinized; anterior edges of hypostoma swollen and very regularly carinated; gula sunken. Presternal ochraceous places small, square, and separated by the distance of their width; posterior area of pronotum irregularly striate, then coarsely granulate behind, the striae rather widely separated and sharply impressed. Ampullae finely granulate, very smooth and shining between granulate area; pleural dises a rather conspicuous granulate area; spiracles very small, nearly orbicular, about as large as ocellus.

Pupa: Pronotum glabrous except for a group of hairs on anterior angles and a few on mesonotum and metanotum; abdominal terga bearing very slender acute spines arranged about as in Chion, but each having a long hair from base; seventh bearing eight recurved spines on posterior margin; a few very small points on eighth; lateral region of terga hairy.

Described from specimens Hopk. U. S. 11s5̃.a.] 
The larva has been found only in small dead twigs of Quercus and Castanea which it completely hollows. Not much of the frass is extrucled and pupation takes place in the early summer between two wads of fibrous chips. It is often found in branches girdled by Elaphidion. The adult is common on the flowers of Chrysanthemum leucothoeca and Achillia millefolium. Range, central and eastern United States and Canada.

\section{BATYLE IGNICOLLIS Say.}

A single larval skin of this speeies is the only material found and eannot be adequately described. The anterior inargin of the hypostoma is slightly wrinkled but not carinate, as in other speeies.

[Deseribed from speeimen Hopk. U.S. 12695.]

Collected by A. B. Champlain in dead branches of Pinus flexilis, Colorado. The work is similar to that of the eastern species.

\section{BATYLE sp. (probably PEARSALLI Blandford)}

Distinguished from suturalis as follows: Carinae on hypostoma finer; first joint of antennae transverse, about equal to third, second much longer; irregular striations on posterior area of pronotum deeper; ampullae alutaceous; spiracles larger, somewhat D-shaped.

[Described from specimens $12617 b$.]

These specimens were collected, but not reared, from Rhus in Colorado by A. B. Champlain.

\section{CROSSIDIUS PULCHELLUS LeConte}

Form cylindric, somewaht robust; integument tough, shining, very hairy; head more strongly tapering anteriorly and gena not so strongly shouldered as in most species; mandible having a sulcus on outer faee; oeellus small; labrum sub-orbicular; first joint of antennae about as long as wide, equal to third, second longer; last joint of maxillary palpi indistinctly longer than second; proeess of palpifer indistinet; anterior edge of hypostoma smooth.

Prothorax quadrate, posterior area of pronotum striate; lateral plates distinct; presternal plates square or lengthening posteriorly, widely separated; mesonotum and metanotum finely granulate; ampullae dull, finely granulate; only one transverse suture distinct; pleural dises granulate, rather distinet; spiracles small, sub-orbicular, but little larger than ocellus.

[Described from specimens Hopk. U. S. 10075 $\%$.]

The larvae were collected in the roots of Artemisia. It was associated with a species of Mecas and Sesia which, working together, entirely destroy the larger roots and base of the stem. ()bservations by A. B. Champlain in ('olorado.

\section{DENDROBIAS MANDIBULARIS Serville}

Form robust, cylindrical, then slightly compressed posieriorly; sparsely hairy; epistoma suddenly emarginate behind elypeus; labrum broadly oval to sub-orbieular, hairy; antennal joints subequal; mandible with a suleus on outer face; joints of palpi subequal; process of palpifer very distinet; anterior margin of hypostoma swollen, bearing four more or less distinct tubercles. Pronotum posteriorly coarsely striate, the striae somewhat pinnately arranged behind; tergal plates prominent, lateral absent; presternal plates square, willely separated; eusternal glabrous spots triangular; ampullae strongly alutaceous, shining, posterior ventral ones somewhat divided and between the lobes longitudinally wrinkled. Spiracles narrowly oval, peritreme thin.

[Described from speeimens Hopk. L, s., 10066.]

The larva has been collected by Geo. Hofer in the dry dead branches of Parkinsonia in Arizona. The work resembles that of Chion, but a much longer mine was excavated through the centre of the branch. Pupation oceurred between two wads of fibrous frass.

A specimen (Hopk. U.S. 9785. ${ }^{1}$ ) of larva belonging to this genus from Mexico has the lateral orange plate of the prothorax somewhat distinct, but otherwise the same. 


\section{Subfamily LEPTURINAE}

In this subfamily are placed the Necydalini and other lepturiform ceramloceick. ('onsidering the typical forms they comprise a very distinet group, biut the Necyclalisi show many affinities to the Aseminae. For the present, howerer, they are retained here.

Considering the typieal forms, they are generally more or less depressed and coarsely haired. The dorsal margins of the cpicranial halves are entirely angulate behind the front; the clypeus is wide and the mandibles are acute at the apex. The pronotum is rarely defined as a definite plate but fused with the proalar area to form the large protergum, the anterior margin of which has a transterse chitinous band of contrasting colour. The epipleurum prominenty projects on all abelominal segments, and has a distinet tubercle but never a distinct pleural dise. The ampultie are tuber'uliform. The legs are well developed for cerambycids.

\section{The characters of the Lepturinae may be briefly summarized as follows:}

\section{CHARACTERIZATION OF LARVAE OF THE SUBFAMILY LEPTURINAE}

Hcad transverse, dorsal margins of epicranial halves behind front entirely separated, angulate tentorial cross-arm internal, in a plane at right angles to hypostoma (i.e., occipital foramen not apparently divided into an anterior and a posterior portion).

Mandibles usually cuneate, cutting edge oblique, apex produced, acute.

Epistoma not produced over clypeus, three to five setae on each side; clypeus trapezoidal, as wide at base as epistoma; labrum transverse, semicircular or cordate.

Maxillae movable; cardo visible; maxillary selerite full; ventral mouth-parts attached by cardo and submentum to edge of hypostoma for nearly its entire width; palpifer large, distinct, bearing lacinia.

Antennae frail, short, very retractile.

Prothorax having presternum and epipleurum separated by distinct suture; eusternum distinet, triangular; coxae large, almost meeting internally between eusternum and sternellum. Mesothoracic spiraele not protruding into prothorax. Legs slender, quite long.

Abdomen with region surrounding spiracle not protruding; epipleurum strongly protuberant on all segments; pleural dise never present; hypopleurum distinet; coxal lobe large.

\section{KEY TO THE GENERA LEPTURINAE}

Gula distinct, raised, sutures protuberant; antennae fleshy, joints seareely retractile into a large antennal ring situated more dorsad (easily seen when viewed dorsally); form cylin-

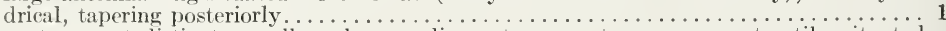
Gula sutures not distinct, usually only a median suture; antennae very retractile, situated more laterally; sides of head more broadly rounded in front................... 3

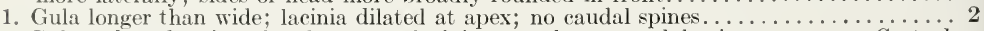
Gula as broad or broader than long; lacinia normal, two caudal spines..........Centrodera

2. Posterior area of pronotum and ampullae finely asperate. Feeds in base and roots of

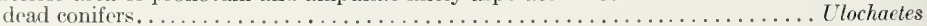
Posterior area of pronotum and ampullae nor asperate.................... Necydalis

3. Front (of head) bearing a transverse suture behind epistoma $\ldots \ldots \ldots \ldots \ldots \ldots \ldots \ldots 4$

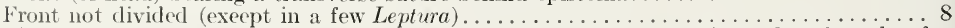

4. Abdominal ampullae present on only six segments; two caudal spines; dorsal angle of

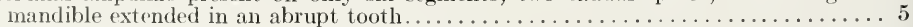

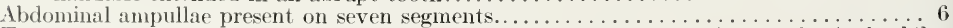

5. Two caudal spines; three ocelli, sometimes indistinct. Feeds on decaying wood.... A nthophilax

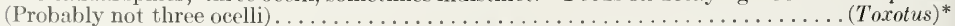

6. Form subeylindrical; mandibles short, triangular from side; three prominent ocelli;

eusternum of prothorax triangular; legs longer than one-half distance between them;

Feeds in base and roots of Sambucus......................... Desmocerus

Form depressed; mandibles very slender from side; ocelli never three............... 7

7. Eusternum trapezoidal; legs shorter; ampullae tuberculate; no caudal spine. Feeds

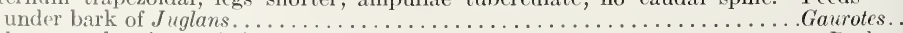

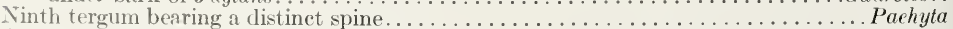

8. Ampullae present on only six abdominal segments, very deeply bilobed, tuberculate; one large ocellus; proeusternum triangular; spiraeles very small. Feeds on the

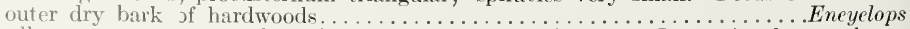

Ampullae present on seven abdominal segments (except in a few Leptura), of normal

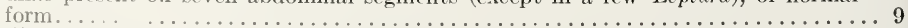

9. Mandible deeply bifureate or notched at apex, slender; form depressed; ampullae dull,

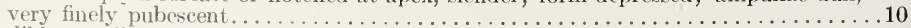

Mandible usually short, triangular, eutting edge long, extending obliquely baekward,

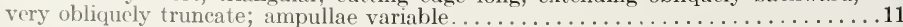

"Characters taken from Schiodte (31). 
10. Head wider than thorax; anterior angles of gena keeled; ocelli indistinct; proeusternum trapezoidal. Feeds under bark of conifers.......................... Rhagium

Head not wider than thorax; five ocelli on each side of head; proeusternum

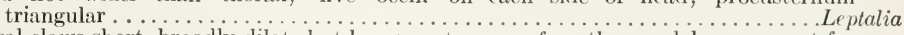

11. Tarsal claws short, broadly dilated at base; eusternum of prothorax glabrous except for two triangular spots of velvety pubescence at posterior extremities; posterior border of spiracles bearing a longitudinal series of carinae............... Bellamira

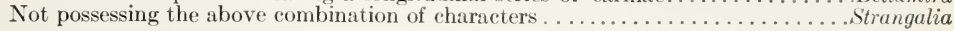

\section{Tribe NEGYDALINI}

'The larvae of this tribe show a strong and undoubted relationship to the Aseminae. This is illustrated in the tendency (in some species) of the dorsal margins of the epicranium to be slightly fused and in the short, robust, triangular mandible. In Ulochaetes it is shown by the velvety asperate pronotum and ampullae, and the two lateral impressions marking off the ambulatory ampullae, caused by the splitting of the strong muscles from the posterior cuneal notch. The legs are weaker than in other Lepturinae and jointed as in the Aseminae.

They may be characterized as follows:

Head subcordate, strongly tapering in front, widest behind middle, having, in some species, the dorsal margin of epicranium behind front slightly fused, suggesting Aseminae; antennae fleshy, situated rather more dorsally than in other Lepturinae, and less retractile, basal membrane incapable of retraction into large antennal fovea, third joint minute; labrum usually transverse; ventral mouth-parts very fleshy and, though widely articulated at base to anterior edge of hypostoma, not filling entire width; lacinia large and usually broader at apex though less so in Ulochaetes; ocelli absent or minute, indistinct; gular sutures protuberant.

There is a tendency for these larvae to be covered with fine asperities, most marked in Ulochaetes, and the ampullae are closely beset with bead-like tubercles in all species of Necydalis. The epipleurum is very narrow. The body is soft and fleshy, slender, tapering, cylindric.

The species may be separated as follows:

\section{KEY TO THE SPECIES OF NECYDALINI}

Posterior area of pronotum and ampullae finely asperate; mandibles having a deep suleus on

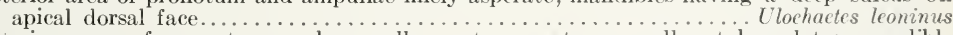
Posterior area of pronotum and ampullae not asperate; ampullae tuberculate; mandible variable.

Mandible having a deep sulcus; ampullae dull, tubereles very few, almost

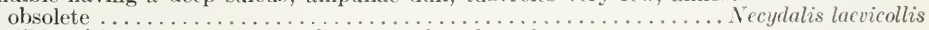
Mandible without a sulcus; ampullae strongly tuberculate.

Gula sutures strongly protuberant; ampullae tubereles many, contiguous . . . . N. cavipennis Gula sutures but slightly protuberant; ampullae tubereles fewer, separatel...... N. mellitus

\section{ULOCIIAETES LEONINUS LeConte}

\section{[Pls. IV, XVII, XXIII, XXIX]}

Form elongate, robust, cylindrical; integument thin, shining, very sparsely clothed with very fine, short, whitish hairs.

Head subcordate, widest just behind middle; mouth-frame dark, corneous, in sharp contrast to white head; epistoma straight, often bearing two small tubercules; clypeus thin; labrum transverse, fungiform, clothed with slender yellowish hairs; mandible triangular from side, shining rugose at base, bearing a deep oblique sulcus on apieal dorsal face; antennac rery fleshy, retractile, articulating membrane large, conical, first joint shorter than second, third minute; one ocellus, scarcely visible; gena rapilly tapering, beset with short fine hairs as well as anterior part of front and hypostoma. Ventral mouth-parts fleshy; lacinia large, fleshy, broadened at apex, sparsely haired; basal joint of maxillary palpi largest, second and third subequal, third conical, last labial shorter than basal, cylindrical; ligula short, thick, with a median groove; gular sutures rectangular, longer than wide, parallel, prominent, protuberant.

Prothorax transversely elliptical, well covered with fine asperities; pronotum rectangular, anteriorly glabrous, posteriorly covered with fine asperities. Eusternum triangular, fincly asperate; mesonotum and metanotum and mesosternum and metasternum more finely asperate; legs fleshy, five-jointed (including coxa), tarsus thick, chitinous tipped.

$57951-6 \frac{1}{2}$ 
Thimun "glindrical; ampullas prominent, funcly asperate, with two lateral curved sutures

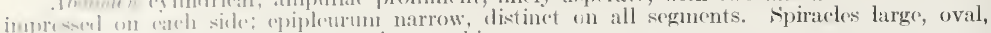

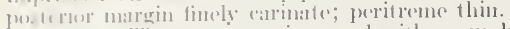

f'ym. 'The promotum is armerl will a mumber of conieal spines, chitinous tipped, disposed

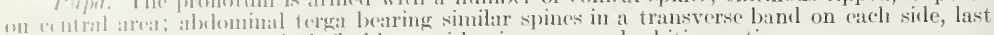
tergum with two loug, conical, fleshly corei having recurved, chitinous tips.

The larva of thochactes bores in the dead roots of Pinus ponderosa, Picea, and chicfly l'sendotsuga. The mines are extended through the soft sapwood and deep into the heartwood, tightly packed with fine, shrededed frass. Before puphting the larva sometimes works higher into the stump, but usually emerges near the gromel. It pupates in May or Jume. Specimens have been collected by \. I). Hopkins, R. Hopping, H. E. Burke, and W. D. Edmonston throughout British Columbia, Oregon, IVashington, and California.

\title{
NEGYDALIS CAVIPENNIS LaConte
}

\author{
[Pls. XI, XXII]
}

Form more slender but in general similar to Ulochaetes; labrum broadly cordate, rounded in front; second joint of antennac about twiee the length of the first, last minute; mandibles as in Clichaetes, exeept that the oblique sulcus is absent and the outer face is less rugose. Pronotum anteriorly glabrous, posteriorly rugose; body devoid of all asperities; ampullae thickly covered with small, bead-like, entiguous tubereles, irregularly disposed. Spiracles small, broadly oval, peritreme thin.

[Deseribed from specimens in the United States National Museum eollected in heartwood of dead oak (Quercus densiftora) in California.]

A number of specimens in the U.S. Forest Insect Collection which cannot be distinguished from this species have been taken by M. Chrisman from dead Almus stumps in Arizona (Hopk. U. S. 10355a), from Eucalyptus in California by A. D. Hopkins (Hopk. U.S. 1094), and from Heteromeles in California by F. B. Herbert (Hopk. U. S. 13178d).

\section{NECYDALIS MELLITUS Say}

Form stender, slightly tapering. Distinguished from $N$. cavipennis by the fact that the posterior area of the pronotum is smooth and shining, or with few indistinct markings, and the tubereles on ampullae separated, smaller and fewer, irregularly arranged in four rows. The labrum is narrowly transverse, twice as wide as long, the anterior margin densely ciliate; the second joint of the antennae is slightly lcnger than the first, the last about equal to the first; the gular sutures are less prominent. The posterior angles of the proeusternum have a spot of fine velvety pubescenee. The spiractes are minute, sub-orbicular, and the peritreme fleshy.

[Deseribed from specimens Hopk. U. S. S685a.]

This larva is a heartwood feeder in the solid dead wood of Quercus and Castanea throughout the eastern United States. The mines are tightly packed with frass. Dr. A. D. Hopkins has collected the larvae at Kanawha, doing considerable damage to solid white oak trestling. The adult flies throughout Junc and July. Observations by Dr. A. D. Hopkins and the author.

\section{NEGYDALIS LAEVICOLLIS LeConte}

Form more slender than in Clochaetes; labrum transverse, roundly reetangular, thin, anterior margin straight, ciliate; mandible as in Ulochaetes (sulcus distinct), but more tapering; laeinia very broad at apex, densely ciliate; gular sutures very prominently protuberant. Posterior area of prothorax glabrous, finely wrinkled; proeusternum, mesonotum and metanotum very finely, velvety pubescent; ampullae dull, finely velvety pubescent, bearing a few seattered, shining, bead-like tubereles. Spiracles large, sub-orbicular, fleshy rimmed.

[Deseribed from specimens (Hopk. U.S. 955sb).]

rollected by the writer in solid heartwood of living Picea engelmanni. Joseph, Oregon. The larrae entered through an old blaze. 


\title{
CENTRODERA DECOLORATA Harris
}

\author{
[Pls. XIV, XI, XXII]
}

Form elongate, cylindric, slightly tapering; integıment finely wrinkled, shining, very sparsely slothed with slender whitish hairs.

Head sub-orbicular, narrowing in front, beset with seattered slender setae; mouth-frame not heavily corneous; clypeus thin; labrum transversely sub-orbciular, regularly rounded in front, little wider than long, anterior margin ciliate, hairs golden; mandible trapezoidal from outer face, black, shining, cutting edge very oblique, long, dorsal angle flattened; antennae acutely conical, basal membrane large, not retractile; first, second, and third joints respectively smaller, supplementary joint as large as fourh; one indistinct ocellus. Interior edge of hypostoma broadly curved; ventral mouth-parts extendel; palpi slender, last labial shorter than basal, equal to last maxillary; lacinia short, cylindric; mentum large, barrel-shaped; gula about as wide as long, strongly protuberant.

Prothorax widest in front; pronotum anteriorly shining, posteriorly rugulose; eusternum acutely triangular, velvety asperate, dull; mesonotum and metanotum dull; mesosternum and metasternum tubereulate. Legs five-jointed, tarsus slender, attentuate, femur longer than tibia.

Abdomen: Dorsal ampullae bearing four rows of large prominent separated tuberctes, ventral two rows; pleural tubercle sub-orbicular, bearing two fine, slender setae. Ninth abdominal tergum bearing two widely separated straight conical spines. Spiracles sub-orbieular, small, peritreme thin.

[Described from specimens Hopk. U. S. 11864.]

These larvae have been reared by the writer from old wet decaying oak $\operatorname{logs}$ (Quercus) in Pennsylvania. Dr. A. D. Hopkins records it from dead heartwood of chestnut and tulip (Liriodendron) in West Virginia. It pupates from May to July.

On June 25, 1915, at Englenook, Pa., the author took numerous larvae of this species working in a hollow dead chestnut (Castanea) in connection with Leptura biforis. The larvae were feeding in the solid wood, eating only the spring tissue of each annual layer. Large galleries were exeavated and a round cell of frass constructed before pupation. An adult was reared in early feptember,

\section{ANTHOPHILAX LeConte}

Only two species in this genus have been reared, but a number of similar larvae are represented in the U.S. Forest Insect Collection. By locality and elimination probable species names have been assigned to some of these forms and the descriptions given.

They all live in very decayed logs lying on the ground. When the larvae are about mature they bore out to the surface of the log and fall to the ground, where an earthen pupal cell is constructed in the soil beneath the humus.

These larvae may be recognized by the tough body integument and coarse hairs; front of head divicled by a transverse suture; three ocelli (often indistinet); mandible short, outer face tuberculate, dorsal angle abrupt toothed; gula not distinet; anterior margin of protergum sirongly chitinized, posteriorly faintly rugulose; mesonotum and metanotum dull, velured, of ten bearing several tubercles; legs very slender; six dorsal ampullae bearing four rows of bearl-like, prominent. separated tubercles; two strong caudal spines.

\section{ANTHOPHILAX ATTENUATUS Haldemam}

\section{[Pls. XI, XXII, XXYIII]}

Form elongate, subcylindrical, tapering; incegmont tough, smooth an l shining, sparsely elothed with stiff reddish hairs.

Head sub-orbicular, wirlesi behind middle, entirely dark castaneous, strongly corneous and thickly beset with slender setae; mouth-frame black; cpistoma straight; clypous and labrum thin, latter transversely oval, one and one-half times wider than long, densely ciliacon roumded front margin; front transversely divided; mandible triangular from outor face, tulberculate, dorsal angle abruptly toothed, acute, entting elge obliguely emarginate; antemme, very small, entirely retractile; three indistinct ocelli. Interior margin of hypostoma thickencel, broatly eurved; gula not distinet; palpi very slender, last joint of mixillary palpi slender, acute, Ionger than second, about equal to last labial; lacinia shortly conical, thick, densely hairy.

Prothorax twice as wide as long, more coriacious than usual; anterior margin of pronotum and proalar area strongly chitinized, castaneous; posterior area of pronotum faindy rugulose; 
(m-17mam semi-coriaceous, shining; mesonotum and metanotum velvety pubescent, each with a melim gromp) of shining tulberese; mesostermm and metasternum tubereulate. Legs somewhat corntiol, slender, tihia longer lhan femur, tarsus a very slender attenuate spine.

thetumen: six dorsal ampullac, hearing four irregular rows of very prominent, bead-like, senciled tulereles, ventral ampullae bearing two rows; seventh and eiglith terga bearing a transverse row of diak redelish hars; pleural tubercle narrowly oval, bearing five or six long, druk reldish setile; ninth tergum more chitinized, bearing two acutely conical, slightly diverging, stromgly chitinous spines, widely separated; anal lobes densely covered with eastaneous hairs. sipirales oval, peritreme strongly chitinized.

[Deserilued from specimens Hopk. U.s. 12631a.]

The larva lives in very moist decaying hardwood logs, chiefly Fagus, Betula, Acr, and Populus, making large, irregular galleries loosely packed with fibrous frass. ('aged larvae invariably leave the wood and go deep into the ground to pupats. The described specimens were reared from Populus tremuloides collected by $\hookrightarrow$. A. Rohwer at Boulder Junction, Wis.

\section{ANTHOPHILAX (IIOFFMANI Beutenmuller.)}

[Pls. XI, XXII]

Distinguished from A. attenuatus by the three prominent ocelli; caudal spines contiguous at base, short, conical, the surrounding area darkly chitinized; last joint of maxillary palpi one and one-half times longer than second; claw of the legs equal in length to the tibia. Spiracles rectangularly oval; anal lobes hairy, but not so densely so as in $A$. attenuatus.

[Described from specimens Hopk. U.S. 9790l.]

These larvae were collected by T. E. Snyder and the author on the top of Mt. Mitchell, North Carolina, in decaying logs of Picea and Abies, but no adults were reared. They have the similar habit of entering the ground before pupation. A deformed adult was reared (Hopk. U.S. 12897), probably A. hoffmani, the larva of which is similar to the form described above.

\section{ANTHOPHILAX VIRIDIS LeConte}

Resembles A. attenuatus, but the body hairs are finer and the caudal spines are erect, cylindrical, and suddenly acute at apex.

[Described from specimens Hopk. U.S. 11876c.]

These specimens have been collected by the writer at Charter Oak, Pa., in dead logs of Fagus, Betula, and Acer.

\section{ANTHOPIILAX sp. (TENEBROSUS LeConte)}

Distinguisher from $A$. attenuatus by the larger contiguous tubercles on ampullae; anterior and posterior borders of ampullae velvety asperate; caudal spines very short, not longer than wide at base, approximate.

[Described from a single specimen, Hopk. U.S. 4793c.]

Collected by H. E. Burke from dead Pseudotsuga, Oregon. It may be tenebrosus.

J. Brumner reports A. tenebrosus breeding in old decayed logs of Picea and Pseudotsuga in Idaho and Montana.

\section{TOXOTUS Serville}

No specimens of this genus have been studied except the cotype of $T$. cursor described by schiodte. It very closely resembles our species of Anthophilax but has only one ocellus.

\section{DESMOCERUS Serville}

A single genus represents the tribe Desmocerini in North America. The species of larvae are remarkably similar in the minutest details of structure. They can scarcely be separated except by size and texture of hairs. They possess, as larvae, no distinctive characters setting them off from other Lepturinae as a tribe, but are distinguished only by a combination of characters. 
They may be recognized by the sub-orbicular head, tapering in front; short mandible; front divided behind epistoma by a transverse suture (sometimes rather faint); three large, prominent ocelli; gula not distinct; pronotum posteriorly shining, rugulose; mesonotum and metanotum not tubereulate; tubercules of ampullae ill-defined, confluent; no caudal spine.

\title{
Sambucus.
}

All larvae have the similar habit of feeding in the base and roots of living

\section{DESMOCERUS PALLIATUS Forster}

\author{
[Pls. XVII, XXXI]
}

Form elongate, robust, slightly depressed; integument firm, shining, glabrous except for a few long hairs.

Head sub-orbicular, tapering in front, sparse long setae on front and gena; mouth-frame strongly corneous and entire head somewhat more than usually chitinized; epistoma thin, semituberculate in middle; elypeus and labrum thin, latter narrowly transverse; mandible short, black, shining, cutting edge short, truncate, dorsal angle of cutting edge not produced; antennae very small, entirely retraetile into fovea; ocelli three, prominent, bead-like. Ventral mouthparts slender; mentum elongate, tapering; lacinia, conical slender, beset with several hairs ; last joint of palpi acutely conical, equal to seeond; gula not distinet, indefinably fused with submentum.

Prothorax transverse, trapezoidal, widest in front; pronotum smooth, shining, posterior edge faintly reticulated, anterior strongly punetate. Eusternum acutely triangular, glabrous, shining, except for several hairs; mesonotum and metanotum not tubereulate, faintly shining; sternum tubereulate; legs very long, tibia longest joint, tarsus short, chitinous-tipped, appendiculate.

Abdomen: Ampullae broad, flattened, tubereles ill-defined, confluent; epipleurum distinet on all segments; pleural tubercle narrowly oval, bearing two long setae; tergum of ninth segment broad, extending over anal lobes. Spiracles large, orbicular, deep, peritreme very thin.

Pupa. Anterior area of pronotum beset with short, subulate hairs; first six abdominal terga bearing numerous recurved, conical spines, more abundant on posterior margin, seventh and eighth terga bearing attenuate hairs from chitinous pores, ninth with two widely separated, long, slender spines, extending laterally and posteriorly.

The larvae feed in the living roots of Sambucus, working deep under the ground until nearly matured, when they come up through the pith and excavate the pupal cell. The mines are packed with coarse, fibrous frass, which is often exuded in large quantities at the base of the stems. Various sizes of larvae can be found at the same time, indicating a larval period of several years. Pupation occurs through April and May. The adults feed on the flowers. Range, throughout the eastern and central United States and Canada.

Rathvon (26) gives a brief note and description of this species.

\section{DESMOCERUS PIPERI Webb}

Distinguished from palliatus by the denser castaneous hairs on the anterior margin of the labrum; two broad median impressions on the front; inner apical face of lacin at bearing a dense brush of hairs; mesonotum and metanotum anteriorly dull, covered with very fine velvety asperities; femur and tibia of equal length; ampullae less strongly tubereulate.

[Deseribed from specimens Hopk. U.s. 12300.]

This species makes a large gall, often 10 inches in diameter, at the base of stems of Sambucus, sometimes killing them. The larvae feed in this abnormal growth and in the roots, going above ground in the pith to pupate. The pupae were collected March 14, 1914, at Riggins, Idaho. The adults emerged in early May. Observations by Josef Brunner.

\section{DESMOCERUS GRIBRIPENNIS HOIn}

Separable from $D$. piperi only by the more slender hairs on head and body, the less distinetly tubereulate ampullae, and the smaller spiracles, which are seareely chitinous rimmed.

Pupa. The pupa is much sinaller than that of $D$. palliatus; the hairs on the pronotum are more slender, and there is an additional group of the posterior margin; and each spine on the abdominal terga ends in an attenuate hair.

[Deseribed from speeimens Hopk. U. s. 4313a.]

The eggs are laid in the crevices of the bark of sambucus at the base of the stem, the larvae tunnelling through into pith where they continue to 
work up and down until cach matured larva oecupies the entire cavity exeavated hy it. Viter antting an exit hole through to the bark it retreats into the pith (1) pupate. P'upare and young larvae were found at the same time, indicating a latral perioul of several years. Many of the stems are killed. OJservations h. H. H. Burke, Ipril 20, 1906, Pialschice, Wash.

\title{
GAUROTES GYANIPENNIS Siay.
}

\author{
[Pls. IV, XVII $]$
}

Form strongly depressed, subparallel; integument smooth, shining, sparsely clothed with very long, castancous, attenuate hairs.

Head very depressed, transversely oval, wilest at mildle, strongly eoriaceous and besct wilh numerous slender setae; epistoma very thin, straight, fused with elypeus at middle; clypeus and labrum thin, latter wice as wide as long, anterior margin rounded, ciliate; front transversely divicled; mandible very slender from side, more than twice as long as wide at base, tip dilated slightly, eutting eflge shor, truncate; antennae very small, retractile; ocelli two, of en indistinct. Interior edge of hyposioma thin, siraight; mentum transverse; palpi very slender; last maxillary joint acute, as long as second; last labial acutely conical shorter than basal; laeinia cylindrie; gula not evilent, a single suture.

Prothorax $t$ wice as wide as long; pronotum undefferentiated, smooth, shining. Eusternum smooth, broadly rounded in front; mesonotum and metanotum velvety asperate, only meiasternum tuberculate. Legs slender, femur and tibia subequal, tarsus attenuate, eurved.

Ibdomen mucl depressed; dorsal ampullae bearing four rows of small, prominent, configuous tubercles; the ventral ampullae, two rows; pleural tubercule oblong, oval, bearing five setae, nintli tergum fringed with numerous long setae. Spiraeles orbieular, prominent, peritreme wide, ehitineus.

[Describud from specimens Hopk. L. S. 1035s.]

Pupa. Front of head around base of antennae beset with a few strong hairs and a group above eyes; anterior, posterior, and lateral margins of pronotum bearing a single row of closely set, long hairs, row on posterior margin forming an angle; mesonotum glabrous; metanotum bearing two patehes of long hairs and each abdominal tergum also bearing a transverse row, broken in middle, of finer hairs; last tergum bearing a short, straight, aeute spine.

This species feeds between the bark and wood of dead walnut (Juglans) in a mamner similar to that of Rhagium. It has also been found in Quercus, Prunus, Rhus, Nyssa, and Cornus. Mr. A. B. Champlain records this larva as leaving the bark and going into the earth or humus to construct its pupal call.

\section{PACHYTA Serville}

\section{$[\mathrm{Pls} . \mathrm{I}, \mathrm{XXII}]$}

A large series of larvae are represented in the U.S. Forest Insect Collection from which no adults have been reared. They have been associated with adults of Pachyta. There areseveral species represented. All work under the tight, recently dead bark of Tsuga, Abies, Pinus, except one species collected by the writer in apple (Malus). Caged larvae have the same habit as Anthophilax of entering the ground before pupation.

Form elongate, parallel, depresseel; quite hairy; head sub-orbicular, depressed; mandible very slender, squarely shouldered at base, apieal half strongly bent down, eutting edge very oblique, truncate, abruptly toothed; front bearing a transverse suture behind epistoma; labrum transverse; one prominent oeellus. Posterior edge of pronotum velvety pubescent; seven abdominal segments, tubereulate; dorsal area of ninth segment protruding, slightly ehitinized, armed with an obtuse or acutcly conical spine, aceording to the speeies.

The following specimens representing several species are in the Forest Irscet Collecticn

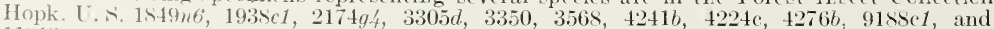
$11813 \%$.

\section{RHAGIUM LINEATUM Oliver}

\section{[Pls. I, XI, XVII, XLX, XXII, XXXI, XLII]}

Form very depressed, elongate, parallel; integument smooth, shining, sparsely clothed with fine, silky, whitish to yellowish hairs.

Head greatly depressed, strongly ehitinized, wider than prothorax, sparsely eovered with fine, silky, short hairs, sides rounded, with a dull earina on anterior margin; epistoma straight, fused into elypeus at middle; front with two elongate, shallow depressions; elypeus and labrum 
very thin, latter obtrapezoidal, rounded and widest in front, cilia dense, fine; epistomal setae six or more. Mandibles very slender from side, nearly three times as long as basal width, apex dilated, deeply notched; antennae small, entirely retractile; ocelli indistinct. Ventral mouthparts well extended; mentum obtrapezoidal; palpi very slender, last maxillary joint attenuately acute, equal to last labial, shorter than first or second maxillary; lacinia slender, eylindrie; anterior margin of hypostoma straight, not distinet from mouth-parts; gula not distinct.

Prothorax widest in front, dorsally undifferentiated, entirely smooth, slightly chitinized; eusternum trapezoidal, broadly rounded in front, smooth, shining; mesosternum and metasternum, mesonotum and metanotum dull, very finely velvety pubescent. Legs slender, femur and tibia subequal, tarsus slender, attenuate, not strongly chitinized.

Abdomen depressed; ampullae semi-tuberculate at sides, dull, very finely pubescent; pleural tuberele very elongately oval, bearing five or more setae; last abdominal tergum broad, bisinuate on posterior margin. Spiracles orbieular, peritreme distinet, raised, not strongly chitinized.

Pupa. Subconvex, tapering; anterior and posterior margins of head and posterior margins of prothorax and metathorax with two transverse bands of upright setae; abdominal terga bearing transverse bands of reflexed subulate setae; last tergum bearing two tri-acuminate spines.

The larvae of Rhagium have been collected between the bark and wood of all our coniferous trees excepting the species of Cupresseae. They require a certain amount of moisture, usually preferring trees which have been dead only a short tine. The larvae construct an oval, fibrous-rimmed pupal cell, pupating and trarsforming to adults in the early fall, and overwintering as imagoes. The larval pericd usually is completed in one stason or may extend over two. The species occurs commonly throughout the United States.

Rathvon (26) gives a brief note on this species, stating that it kills pines. It is improbable that such could be the case.

Packard (23) gives a description of the larva and figures it. Although not detailed, these are suff.cient to permit of its recognition.

\section{LEPTALIA MAGILENTA Mannerheim}

[Pl. 1, fig, 1]

Form depressed, slightly tapering posteriorly; integument thin, dull, very finely granulate, and very sparsely beset with long slender hairs.

Head depressed, sub-orbicular; mouth-frame little chitinized; three epistomal setae; labrum twice as wide as long, widest at base, anterior margin rounded from basal angles; mandibles slender, twice as long as basal width, cutting edge short, oblique with dorsal angle very abruptly protruding, tip truncate; five more or less distinct ocedli in two rows. Ventral inouth parts slender; maxillary palpi very slender, joints subequal; ligula broad; anterior edge of hypostoma thin; gular suture sometimes faintly visible.

Prothorax transverse, depressed; pronotum entirely smooth; eusternum very finely asperate, dull; mesonotum and metanotum and mesosternum and metasternim dull, very finely asperate. Legs slender, tibia longest, tarsus very attenuate.

Abdomen: Ampullae seven, dull, very finely asperate; pleural tuberetes very small, oval, projecting, bearing two very slender setae. Spiracles small, orbieular, peritreme very thin.

[Described from specimens in the United States National Museum collected by Kincaicl in decaying alder stump (Alnus). Popof Island, Alaska.]

Kincaid (18) gives a very good description of this species. It is better than most North American descriptions of cerambycid larvae. The writer has re-described it here to conform with the terminology used throughout this paper.

\section{ENGYGLOPS GAERULEUS Say.}

\section{[Pls. I, XXiI]}

Very slender, tapering, quadrangular; integunent smooth, shining, very sparsely covered with long, silky hairs

Head sub-orbieular, widest at middle; mouth-frame slightly corneus; epistonia thin, fused at middle with clypeus; elypeus and labrum thin, latter transversely oval, broadly rounded on front, beset with few long hairs; mandible slender from sides, tapering apex clull, eutting edge short; antennae very small; retraetile, last joint and suzplementary joint distinct ; ocellus large, distinct. Anterior edge of hypostoma thin, not sharply distinet from mouth parts; mentum transverse; last joint of maxillary palpi distinctly larger than either of others, equal to last labial; gula indistinet.

Prothorax slightly wider than long, pronotum glabrous, undifferentiated; eusternum acutely triangular, glabrous; mesonotum and metanotum subtubereulate, sbining, sternum tubereulate: shining. Legs slender, very fleshy, femur and tibia subequal, tarsus attenuate, soft. 
Ibetomen tetragonal. Ampullae only six, promineutly projecting, bilobed by a deep median furrow, cach lobe regularly tuberculate; parascutal and coxal lobes large, protuberant; pleural tuberde large, orbicular, bearing two long slender setae. Spiracles orbicular, small, not larger than ocellus, peritreme fleshy.

l'upe. Body covered with a group of fleshy papillae bearing slender, fine hairs, as follows: two lateral groujs on epicranium, on lateral margins, and on posterior margins of pronotum; if recurvel transterse group on abdominal terga becoming denser at posterior margins of eighth and ninth terga.

[Described from speeimens Ilopk. U. S. 9792b.]

The larva of Encyclops has the peculiar habit of mining in the outer dry corky bark of Quercus alba, Liriodendron, Acer, Castanea, Juglans, and Nyssa. It often works in numbers on certain limited areas of bark, causing the scales to flake off after a time and the bark to appear smooth. The pupal cell is merely a shallow excavation, in which the larva overwinters, transforming in early May and June. It is often associated with Microclytus, which has a similar habit. The adult is found throughout the eastern United States, commonly on early shrubby flowers. Both of these insects have a common predatory enemy, a sinall elaterid larva which has not been definitely determined. Observations by A. B. Champlain and the author.

\section{BELLAMIRA SCALARIS LeConte}

\section{[Pls. I, XVII, XXII, XXXI]}

Form elongate, slender, tapering, cylindrical; integument smooth, slining, sparsely covered with short fine hairs.

Head sub-orbicular, widest behind middle, slightly chitinized; mouth-frame strongly corneous, dark; hypostoma thin, straight; clypeus and labrum thin; latter narrowly oval, twice as wide as long, anterior margin flatly rounded, ciliated with castaneous hairs; mandible slender, triangular from side, apex very acute, dorsal tooth strong, acute, outer face with a band of fine striae across middle; antennae small, retractile; one rather prominent ocellus. Palpi slender, last maxillary joint conical, last labial cylindric, both shorter than respective penultimate joints; lacinia short, conical; subfossal-spine distinet; gula not distinet.

Prothorax widest in front; protergum with a transverse, anterior, lemon-yellow band, widened on lateral area; pronotum beset with few short hairs, posteriorly rugulose; sternum more hairy than usual; eusternum triangular and with two triangular blotches of velvety pubecence on posterior angles. Mesonotum and metanotum velvety pubescent; sterna with an anterior band of velvety pubescence, tuberculate. Legs rather stout, tarsus appendiculate, arcuate.

Abdomen; Seven dorsal ampullae bearing four irregular rows of small, projecting, separated tubercles; the ventral ampullae two rows; pleural tubercle sub-orbiculate, bearing two long setae on posterior margin. Spiracles narrowly oval, not strongly rimmed.

Pupa; Very slender, tapering; pronotum with two groups of short subulate setae on posterior margin, two orbicular ones on metatergum, and two transverse groups on each abdominal tergum, the last bearing two conical fleshy spines and a border of more slender spines along hind margin.

The larvae feed indiscriminately in almost all coniferous or hardwood trees provided the proper conditions of moisture and decay are present. They require well rotted $\log s$ in very moist situations. The mines are large and irregular, extend through the sapwood and heartwood, and are filled with loose, fibrous frass. This species has been collected from Fagus, Acer, Populus, Pinus and Tsuga throughout the eastern United States.

\section{BELLAMIRA LeConte, TYPOCERUS LeConte, STRANGALIA Serville, and LEPTURA Serville}

The genera Bellamira, Typocerus, Strangalia, and Leptura, as the adults are grouped by American writers, cannot be recognized as larvae. Bellamira has been separated in the key, but in this case only one species is treated. Evidently several good genera are represented by the larvae here described. Sicarcely any difference can be found between several species of Typocerus and Strangatia, while in the genus Leptura there are some very characteristic groups, as subhamata-like forms having three ocelli and a striated molar plate on the 
mandible. Aurivillius (1) separated the North American species of these genera into Leptura, Judalia, and Oedecnema in certain respects this grouping can be substantiated by larval characters, but as the larvae of so few species have been studied, no definite arrangement is indicated at present. The described larvae may be briefly characterized as follows:

Head sub-orbieular, widest about middle, usually brownish ehitinized; labrum transverse; mandible relatively short, triangular from side, dorsal angle of eutting edge either toothed or flattened into a striate plate, cutting edge very obliquely truncate; ocelli indistinet, or one, two, or three present; edge of hypostoma broadly eurved; gula never (excepion, L. subhamata), distinet. Prothorax transverse. Legs rather slender, tarsus usually slender, attenuate. Proeusternum, mesonotum, metanotum, and sterna dull, pubeseent, glabrous, or tubereulate, affording good characters. Abdomen slender, tapering.

All species so far as known, with one exception (L. nitens), live in dead decaying wood, in very moist situations. The larval period usually extends over more than one year. The species are gregarious, working together for many years in the same $\log$ until it is completely converted into sawdust. They are often associated with the Prioninae. The mines meander and intersect and are tightly packed with fibrous frass. The adults are pollen feeders, being the most abundant cerambycids in early summer months, when they can be collected in great number's on the flowers of various plants.

\section{KEY TO THE DESCRIBED SPECIES OF TYPOCERUS, STRANGALIA, AND LEPTLRA}

Dorsal angle of mandible flattened into a striate plate.

Dorsal angle of mandible merely rounded or bearing an abrupt tooth $\ldots \ldots \ldots \ldots \ldots \ldots \ldots$

1. One ocellus; mesonotum and metanotum velvety pubescent, except for several tubercles

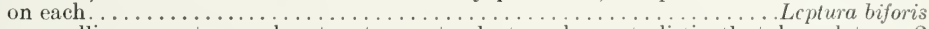

Three ocelli; mesonotum and metanotum not velvety pubescent, distinctly tubereulate... 2

2. Abdominal spiracles very narrowly oval. . . . . . . . . . . . . . . . . . . 3

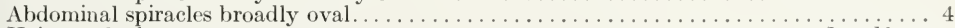

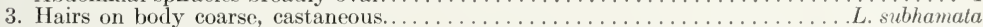

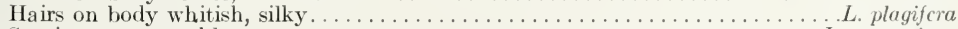

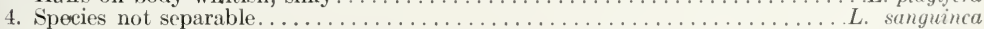

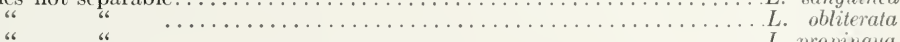

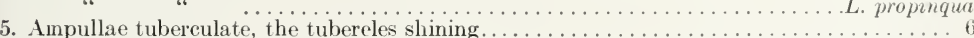

Ampullae not tuberculate, or if so, asperate pubescent . . . . . . . . . . . . . . . . . .

6. Both mesonotum and metanotum bearing tubercles, shining, never entirely pubeseent .... 7

Mesonotum and inetanotum eovered with fine velvety pubeseence, dull (rarely several tubereles on metanotum)

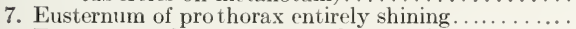

Eusternum of prothorax velvety pubescent or at least on posterior extremities. .

8. Tubercles of ampullae smaller, merely contiguous

Tubercles of ampullae laree (fewer) somet..............

9. Metanotum bearing a small group of three to six shining tubercles; tubercles of ampullae separated.

Metanotum bearing no tubercles.

10. Eusternum of prothorax shining

Eusternum of prothorax covered (or partially so) with fine velvety or asperate pubescence, dull. 
16. 'larsal elaw aretuate, slort; prosternellar area shining

17. I'roenstermm regurlaty heset with stiff hairs. . . . . .

L. canadensis l'roensternum learing hairs only on lateral margin, none in central area, hairs not more thin si to 10

1s. (The ocellus on each side of head

L. rubrica

Three ocelli on each side of head; species not separable

L. mutabilis

L. aspera L. lineola

19. Six alolominal segments bearing ampullac. ... 20 seven abdominal segments bearing ampullate.

2(). Median band between dorsal ampullate asperate

Mledian bind of dorsal ampullae glabrous.

21. Ventral surface of head finely granulate; proeusternum dull, velvety pubescent.

Ventral surface of head shining, smooth; procusternum shining

2.2. Proeusternum finely asperate only on posterior lateral extremities

.. 22

Proensternum finely asperate over nearly entire surface.

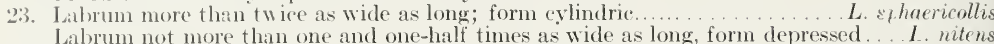

Strangalia acuminata Leptura crassipes L. valida L. vittata I. nitens

\title{
TYPOCERUS VELUTINUS Oliver
}

\author{
[Pls, XIV, XXII]
}

Form elongate, subcylindric, tapering; integument smooth, shining, very sparsley clothed with whitish vellow hairs

Head sub-orbicular, slightly wider than long, somewhat chitinized; mouth-frame strongly corneous; epistoma slightly and roundly protuberant, three or four serae on each side; clypeus and labrum thin, latter semicircular, one and one-half times wider than long, widest behind, bearing scattered hairs; mandible slender from side, apex acute, dorsal angle prominent; antemmae small, very retractile, ring oval; ocellus indistinet; anterior edge of hypostoma distinct; hypostoma broadly curved; gula not distinct, palpi slender, last joint of maxillary obtusely conieal, shorter than last labial or second maxillary; lacinia cylindric.

Prothorax one-half wider than long, pronotum bearing a distinct transverse brownish band, widened at sides, posterior area slightly rugulose, shining. Eusternum velvety pubescent, dull, except for a triangular anterior spot; nesonotum dull, velvety pubescent, as well as metanotum, except for a central group of shining tubercles; mesosternum and metasternum tuherculate. Legs not so slender, no joint twice as long as thick; tarsus attenuate, chitinous.

Abdomen; Ampullae seven, the anterior and posterior margins finely pubescent, bearing small, bead-like, abruptly projecting, separated tubercles; pleural tubercles oval; bearing several slender setae. Spiracles very small, oval to sub-orbicular, peritreme thin.

[Described from specimens Hopk. [. S. 9747.]

()ne of the commonest lepturiform larvae, found in all sorts of decaying hardwoods and conifers, occasionally in rather solid wood. The adults are commonly found on flowers in May and June throughout the eastern United States and Canada.

\section{TYPOCERUS LUNATUS Fabricius}

\section{[PI. XIV]}

Distinguished from $T$. vclutinus by the thinner epistoma, the indistinctly rimmed antennal ring, the more prominent ocellus, smooth and shining eusternum, and the group of tubercles on metanotum usually absent or rarely two. The legs are more slender, the tarsus slightly dilated at base. It is also more hairy then $T$. velutinis.

[Described from specimens Hopk. U. S. 12286.]

This larva was found in dead rotting stumps of Pinus by H. B. Kirk and the author. The adult is commonly collected on flowers in late May and June, from Pennsylvania through the south-central States. Observations by $\mathrm{W}$. F. Fiske, H. B. Kirk, and the author.

\section{TYPOCERUS ZEBRATUS Fabricius}

Several si ecimens of the adults of this species were collected at Falls Church, Va., in a dead stump of Pinus by J. N. Knull and the author. The larvae mined in the roots, coming to the top of the stump to pupate. Only larval skins were secured. 
The mandible is black, shining, very acute, having a strongly curved cutting edge at the upper extremity of which the dorsal angle is produced into a rectangular abrupt tooth; the labrum is roundly rectangular and the pleurostoma bears a small projecting ocellus.

[Described from specimens Hopk. U. s. $11872 d$.]

\section{STRANGALIA BICOLOR swederus}

\section{[Pl. XIV]}

Form very slender, clothed with whitish hairs; integument very finely granulate; labrum subtrapezoidal, widest behind middle, front edge straight for short distance; epistoma very thin; ocellus small; last joint of maxillary palpi slightly longer than second; metanotum bearing no tubercles. Proeusternum velvety pubescent only on posterior lateral angles. Tarsus very slender, attenuate.

This species has been reared from dead Acer and Quercus. The adults occur throughout the eastern Inited States and Canada in June and July.

\section{STRAGALIA FAMELICA Newman}

Differs from $S$. bicolor in that the entire posterior border of the proeusternum is dull velvety pubescent; no trace of tubercles on the metanotum.

[Described from specimens Hopk. [T. s., 10914a.]

This species has been reared from decaying Quercus. The adults are found on flowers in the eastern United States and Canada through June and July.

\section{STRANGALIA LUTEICORNIS Fabricius}

\section{[Pl. XIV, XXX]}

Essentially like Typocerus velutinus, form more slender; head slightly more elongate; mandibles shorter, little longer than basal width; ocellus promincnt; labrum rectangular, sides rounded, front edge straight and (not roundly curved as in $T$. velutinus) widest at middle. Spiracles more strongly chitinized.

[Described from speeimens Hopk. U.s. 12280 $q$ and 11s12a.]

This larva has been reared from dead, moist, decaying wood of Titis, Fagus and Clmus, always in contact with the ground. The adult flies in May and June throughout the eastern United States and Canada.

\section{STRANGALIA ACUMINATA Oliver}

Head bearing many rather stiff hairs, ventral surface and anterior portion of front finely granulate; dorsal angle of mandible prominent; labrum subtriangular, widest at base; one ocellus. Mesonotum and metanotum dull, finely asperate; posterior half of proeusternum and anterior half of sternellum finely asperate; mesosternum and metosternum tuberculate; tarsus attenuate; seven dorsal ampullae bearing four rows of small, nearly contiguous tubercles, no fine asperities between; spiracles broadly oval to orbicular, peritreme strongly chitinized.

Pupa. Short, stiff, chitinous setae at hase of clypeus and antennae, and above eyes, and on posterior border and angles of pronotum which also bears a few fine hairs on dise; mesonotum and metanotum each bearing several short, stiff selac, and a broken transverse row on each abdominal tergum; ventral anal lobes each bearing a conical, suddenly acute process.

[Deseribed from specimens Hopk. U.S. 100s3l]

Collected and reared by A. B. Champlain at Lynne, Conn., in dead Viburnum stems.

\section{LEPTURA BIFORIS Newman}

Head very hairy on anterior portion, sides in front of middle rather suddenly tapering; epistoma thin; labrum thin, transverse, anterior margin rounded from middle and sparsely hairy; manỏible very black, smooth, shining, dorsal angle flattened into a strilte plate, apex very acute; one ocellus; last joint of maxillary palpi cylindrical, shorter than second; gula sutures slightly evident. Proeusternum and siernellum shining; mesonotum and metanotum dull, velvety pubescent except for a group of from three to five shining tubereles on each; femur and tibia subequal, tarsus very slender, attenuate. Impullae seven, tubereles, large, contiguous, four rows on seventh. Spiracles small, oval, peritreme distinct. Hodomen unusually hairy.

Pupa. Form like that of adult; front of head bearing several attenuate coarse setac; two groups of three to five on anterior margin of prothorax and a straight transverse band on posterior margin; several on mesonotum and two groups on metanotum; six to eight shorter setae on each abdominal tergum, becoming more numerous on seventh and eighth and forming a dense fringe on last.

[Described from specimens Hopk. U. s. 11 s64.] 
These specimens were collected by the author from a dead hollow chestnut (' askenca) log at Inglenook, Pa., June 24, 1915. Larvae, pupae, and adults were ahumelant. The larvae were mining the spring wood of a hollow tree. Pupation oceurs in a large oval cell. The pupae were congregated about knotholes through which the adults emerged. A dipterous parasite was taken on about 50 per eent of these pupae, but has not been reared. Associated with this species was the larva of Centrodera decolorata.

\title{
LEPTURA PROXIMA Kirby
}

[Pls. IV, XXII]

Head rery hairy, especially front; epistoma abruptly raised; labrum transverse, broadly rounded in front; dorsal angle of mandible aeute; one oeellus; last joint of maxillary palpi shorter than second. Proeusternum and sternellum shining; mesonotum and inctanotum and sterna tuberculate, shining; femur and tibia subequal, tarsus attenuate; ampullae seven, tubercles large, prominent, contiguous, ventral rows of about nine each, four rows on seventh terga; spiracles oval, dark castaneous.

Pupa. Form like that of adult, bearing two rows of three to five setae on anterior prothorax and setiferous papillae on lateral angles of prothorax and metathorax; also two rows on each abdominal tergum and a fringe on last abdominal segment; apical outer face of each fenur tipped with a group of setae.

[Deseribed from specimens Hopk. U. S. 11811.]

This species has been reared from Acer, Hicoria, Castanea and Tilia. The writer has found it in old standing stubs, which have been completely converted into powder except for an outer shell. Often found in dryer situations than most other species. Pupa collected May 24, 1912, at Charter Oak, Pa.

\section{LEPTURA CHRYSCCOMA Kirby}

\author{
[Pl. XIV]
}

Only separable from L proxima by the larger, more or less confluent tubercles of the ampullae, the ventral rows number seven or eight. Head less hairy.

Pupa. Form as in adult; bearing two transverse bands of short, stiff setae or spines on posterior margin of pronotum, a few on mesonotum, and more numerous ones on metanotum; each abdominal tergum bears a transverse group on each side of the median line and a fringe on the last tergum.

[Deseribed from specimens Hopk. U.S. $12651 a$ and 11921b.]

This larva is described from specimens collected and reared from Pinus flexilis and P. ponderosa by A. B. Champlain. The adult flies through June and July in the Rocky Mountain and Pacific Coast regions.

\section{LEPTURA SUBHAMATA Randall}

\section{[Pl. XIV]}

Head very thickly beset with long hairs; sides rather suddenly tapering in front; labrum cordate, about as wide as long; mandibles slenderly acute, dorsal angle flattened into a striated plate; three distinet ocelli; last joint of maxillary palpi slightly tapering, shorter than second; gular sutures faintly distinet. Proeusternum and sternellum shining, mesonotum and metanotum and mesosternum and metasternum tuberculate, shining. Legs slender; femur and tibia subequal; tarus slender attenuate. Abdomen very hairy, the hairs castaneous. Ampullae seven, last very small; tubereles prominent, large, contiguous. Spiracles narrowly oval, chitinous rimmed.

Pupa. Form as in adult; a group of setae at base of clypeus, at base of each antenna and two on front of head; posterior margin of prothorax with two transverse bands of stiff setae; two oval groups similarly placed, on metanotum and on median area of abdominal terga, the last margined with fleshy conical papillae.

\section{[Deseribed from specimens Hopk. U.S. 11818b.]}

A northern species, usually in higher elevations, breeding in dead logs of Pinus. Larra and pupa collected at Notch, Pa., in June. The adults have been taken through the northeastern and central United States and Canada. Ob-. servations by Dr. A. D. Hopkins, IV. F. Fiske, and the author. 


\section{LEPTURA PLAGIFERA LeConte}

Distinguished from L. subhamata by the very fine silky white hairs on body and head. tergum.

Pupa. Readily distinct from L. subhamata by the absenee of the groups of setae on meta-

[Deseribed from speeimens Hopk. U.S. 4793c, 4711a.]

This larva has been reared only from western yellow pine (Pinus ponderosa) Adults collected in July in Oregon and Washington by H. E. Burke and W. D. Erlmonston.

\section{LEPTURA OBLITERATA Haldeman}

[Pls. IV, XVII, XXVII]

Slightly less hairy than L. subhamata; sides of the head more rounded and gula not distinct. Spiracles broadly oval to sub-orbicular. Tubereles of ampullae smaller and less distinet.

Pupa. Groups of setae arranged as in L. subhamata, but an additional group of anterior margin of prothorax and one of shorter lrairs on disc of prothorax, and on tips of femura.

[Deseribed from specimens Hopk. U.S. 4002d and $9161 y$.]

This larva breeds in a variety of dead conifers and is often associated with the larvae of Asemum and Criocephalus. It has been collected from Abies, Pseudotsuga, Picea, Tsuga, and species of Pinus throughout British Columbia, Washington, Oregon, California, and Montana. It pupates in May and June. Observations by Dr. A. D. Hopkins, H. E. Burke, and E. A. Schwarz.

\section{LEPTURA SANGUINEA LeConte}

This species is always associated with $L$. obliterata, but cannot be separated from it by larval characters. The habits are the same.

\section{LEPTURA PROPINQUA Blandford}

Two specimens of this larva have been studied. The only difference from obliterata is a slightly more hairy head and finer whitish body hairs. These characters are not sufficient to determine it definitely.

The larvæ were collected and reared from Engelmann spruce (Picea engelmanni in Colorado by A. B. Champlain. It was associated with larvæ of Calopus.

\section{LEPTURA SOROR LeConte}

Larvae of this species cannot be definitely separated from the obliterata-like forms. The specimens Hopk. U. s. 14466 c were collected by F. B. Herbert in dead lodgepole pine (Pinus murrayana) at Meyor's, C'al.

\section{LEPTURA NIGRELLA Siy}

\section{(Pl. XVII)}

Head rather thick, robust, clothed with short fine hairs; epistoma roundly declivous; labrum transverse, broadly-rounded from posterior margin; dorsal angle of mandible prominent, broad; one prominent ocellus; last joint of maxillary palpi eonical, equal to second. Proeusternum glabrous, shining; prosternellum and nresonotum and metanotum dull volvety asperate, exeept for several tubercles ${ }^{1}$ on median area of metanotum; legs robust, femur and tibia subequal: tarsus short, coni eally arute. Ampullae seven, tubereles very conspieuously protuberant, separated, bead-like. Spiraeles broadly oval, peritreme thin.

[Described from speeimens Hopk. L.... 2304c.]

The larvae have been collected and reared in species of Pinus, Picea, and Pseudotsuga from Colorado and Oregon. H. E. Burke collected adults in their pupal cells August 20, 1907, at Joseph, Oregon. Range, throughout the western United States and Canada.

1 On several immature specimens these tubercles are indistinct. 
Furm, nol" depressed llatn usial; resenbling a small Gaurotes. Head depressefl, widest at mildlle, bearing a fow long hatis on gona and along frontal sutures; labrum thin, semircircular, longest al milille, widest at hase, twice as wide as long; mandible rather short, dull black, apex blumt, dorsil angle not toot hed; thee sumall black ocelli; anterior edge of hypostoma not flist inct from submentum; maxillany palpi long, basal joints subequal, third longest, rylindrical. Pro(1lsternum shining, bearing a few stiff hairs anteriorly; mesonotum and metanotum dull, finely volvety pubescent; mesosternum and metasiernum tubereulate, shining. Iregs very long, tarsus atlenuitr. Impullae seven, covered with tubereuliform wrinkles (resembles Gaurotes); pleural tuberck bearing two long setae. Spireales small, sub-orbieular, peritreme thin.

l'upa. Form as in adult; bearing seattered stiff hairs on front of head, about dise of pronotum, and on distal portions of femora; mosonotum and metanotum glabrous; abdoninal terga bearing short, stiff, spine-like hairs more or less arranged in two transverse rows, longer oncs on epipleurum; last segment bearing two slender, straight, acute spines, their under sides parallel.

[Describel from specimens Hopk. [.S. 10075k.]

These specimens have been collected and reared by A. B. Champlain and Geo. Hofer from Colorado springs, Col. The larvae mine between the bark ancl wood of recently dead Populus. A round flat pupal cell is constructed resembling that of Rhagium. The adults emerged the latter part of May and in June.

\section{LEPTURA AMERICANA Haldeman}

\section{[Pl. XIV]}

Head quite wide at middle (almost equal to prothorax); labrum roundly reetangular, almost straight aeross anterior margin; mandible abruptly enlarged at base, slender, eutting edge obliquely truneate, dorsal angle abrupt, bidentate; one prominent ocellus; last joint of maxillary blpi slender, equal in length to second. Proeusternum shining; mesonotum and metanotum velvety asperate, dull; mesosternum and metasternum tuberculaie, these larger than abdominal ones; abdomen tetragonal, parascutal and eoxal areas large. Ampullae six, projecting, tubereles very small, bead-like, separated. Spiracles oval, not larger than oeellus, peritreme thin. Body hairs long, slender, yellowish white.

[Deseribed from specimens Hopk. U.S. 11845o.]

specimens of larvae and adults collected in dead decaying tulip (Liriodendron) stump at Falls ('hurch, by H. B. Kirk.

\section{LEP'TURA EMARGINATA Fabricius}

\section{[Pl. XVII]}

Head quite hairy on anterior portion; epistoma abrupily raised, straight, perpendieular; lalorum thiek, transverse, broadly rounded from near base, perimeter densely hairy; dorsal angle of mandible abrupt, prominent; one ocellus; last joint of maxillary palpi aeutely conical, equal to last labial, shorier than the oihers; hypostoma somewhat transversely bulging; gular sutures slightly protuberant, roughened. Proeusternum shining, sternellum dull velvei y pubescent on anterior two-thirds; mesonotum and metanotum entirely dull velveiy pubescent; femur and tibia subequal, tarsus straight, acute. Ampullae seven, surrounded by a narrow band of velvety pubescence, tubereles very small, separated, the two median rows (of dorsal ampullae) separated by a transverse band of velvety pubescence. Spiracles rather small, narrowly oval, peritreme thin.

Pupa. Form like that of adult, bearing groups of short attenuate spines on anterior median margin and posterior lateral portions of prothorax; two median oval groups on metanotum; a transverse band of more conical spines on each abdominal tergum becoming more irregularly dispersed posteriorly, also several along region of parascutum and epipleurum.

[Deseribed from speeimens Hopk. U.S. 11863b.]

This specios can be easily reeognized by the large size of the matured larvae and the structure of the ampullace, surrounded by velvety pubecsence, with also a transverse median band.

These specimens were collected June 11, 1915, from a large fallen beech (Fagus) at Kianawha Station, W. Va. Twenty-five years ago Dr. A. D. Hopkins collected a single adult on the then standing tree, it having emerged from the hollow base. Four years ago it was blown over, and examination on above date by Dr. Hopkins and the writer showed it to be entirely honeycombed by the larval mines, and the outer shell full of larvae, pupae, and adults. The 
mines are very extensive, packed with coarse fibrous frass, and lined by a dark fungous growth. The pupal cells were constructed in the outer shell. This beetle has been breeding in the same hollow butt for the past twenty-five years. The different stages of larvae found indicate the life cycle to be three years. The writer has collected larvae of this species from a dead stub of Quercus at Mt. Vernon, Va., and Mr. A. B. Champlain has taken it from Betula at Lyme, Conn.

\title{
LEPTURA RUBRICA Say.
}

\section{[Pls. XVII, XXII]}

Anterior half of front and gena hairy; epistoma obliquely declivous; labrum transverse, sub-elliptical, anterior edge very broadly rounded from posterior lateral angles; dorsal angle of mandible abrupt; one ocellus; last joint of maxillary palpi arutely' conical, shorter than second. Proeusternum shining, sternellum, mesonotum, and metanotum velvety pubescent, dull; mesosternum and metasternum tubereulate, shining; femur and tibia subequal, tarsus attenuate. Ampullar tubercles beadlike, prominent, separated, four rows usually distinet on seventh tergum. Spiracles oval, peritreme strongly chitinized.

[Described from specimens Hopk. U.S. $9782 k$ and 10377.]

One of the commonest eastern species of Leptura. The larva feeds in a great variety of dead hardwoods and conifers. Both well-decayed and solid wood are suitable to its activity. This is a good illustration of the indiscriminate feeding of our most commonly collected cerambycids. Typocerus velutinus, Xylotrechus colonus, and Neoclytus erythrocephalus are similar examples.

\section{LEPTURA GANADENSIS Fabricius}

\author{
[Pls. XXII, XXVIII]
}

Head thickened, beset with many slender hairs; epistoma abruptly declivous; labrum transversely oval, broadly rounded from behind middle; dorsal angle of mandible abrupt and strong; one prominent ocellus. Proeusternum shining, beset with a number of regularly disposed hairs, otherwise as in L. rubrica, but slightly more hairy and tubereles of ampullae slightly larger and more closely placed.

[Described from specimens Hopk. U.S. 9071d.]

The larvae feed in dead, rather solid wood of various species of Pinus and Tsuga. It commonly attacks the heartwood of living trees, gaining entrance through a wound such as a blaze. Range, throughout the Uniterl Sitates and Canada. The adult flies from June to August.

\section{LEPTURA VAGANS Oliver}

Distinguished from L. rubrica by the more prominent ocellus; tarsus shorter than tibia, flattened and arcuate; prosternellar area not distinctly velvety pubescent; tubereles of ampullae fewer, about six in dorsal rows, seventh ampullae bearing only two rows; spiracles sub-orbicular, petritreme dirty-greenish coloured.

[Deseribed from specimens Hopk. L.s. 1260sa.]

The larvae feed in decaying pine logs throughout the eastern United states and Canada. The larvae were collected and reared by H. E. Kirk. It is often associated with L. rubrica. The adults have been taken in June and July.

\section{LEPTURA LINEOLA Si:Y.}

Head rather thick, hairs short; epistoma thin, labrum but little wiler than long, sides broadly rounded; mandible short, dorsal angles abruptly tootherl; one small prominent ocellus; last joint of maxillary palpi acutely conical, equal to second. Proeustermum and mesonotum and metanotum velvety asperate; mesosternum and metasternum tubereulate, velvety asperate on anterior border; legs slender; tibia slightly longer than femur, tarsus attenuate. Impullar tubercles small promment, present on but six segments. Spiracles orbieular, very small, peritreme lightly chitinized.

[Described from specimens Hopk. [.s. $97 s ! n$.

Collected and reared from sapwood of a dead birch (Betula) stump, at Cedar Mountain, N.C. 
LEPTURA VITTATA Germar.

[Pl. XIII]

llewl hairy on anterior portion of front and gena; epistoma roundly declivous; labrum -ubrefangulir, front edge nearly straight, about twice as wide as long; dorsal angle of mandible alveut; ocellus oral, indistinct; last joint of maxillary palpi cylindric, obtuse, equal in length to second. Interior two-thirds of proeusternmm and sternellmm, and the mesonotum and metat ot um dull, velvet $y$ asperate, as are also the anterior and posterior borders and the dorsal median and of the ampullae; mesosternum and metastermum tuberculate, anterior and posterior edges velvety asperate; tibia slightly longer than femur, tarsus attenuate. Tubercles of ampullae small, irregularly disposed, separated, only two rows on seventh ampullae. Apiracles orbicular, not chitinous rimmed.

[Described from specimens Hopk. U.S. 11847 $\mathrm{c}$ and 11s00.]

The larvae feed in dead decaying Abies, Pinus, Juniperus, and Castanea. It pupates in May and June. Range, throughout eastern United States and Camada.

\section{LEPTURA VALIDA LeConte}

Ilead, sides regularly rounded, bearing a few long setae; labrum transversely oval, about twice as wide as long; mandible rather smooth on outer face, bearing a faint transverse band of striae, dorsal angle very abruptly and strongly toothed; one elongate oval ocellus; last joint of maxillary palpi conical, slightly shorter than second; a single gular suture. Proeusternum velvety pubescent on posterior lateral angles; sternellum velvety pubescent; mesonotum and metanotum velvety pubescent; legs slender, femur and tibia subequal, tarsus slender. Ampullae surrounded by velvety pubescence and having several narrow transverse bands, tubercles very small, abrupt, separated; spiracles oval, scarcely larger than ocellus.

Pира. Head bearing a few setae; two prominent tuberculiform groups of setiferous points on anterior margin of pronotum and two transverse bands on posterior margin; a median spinose tubercle on mesonotum and two on posterior margin of metanotum; a transverse band (divided in middle) of short, acuminate points on posterior margin of each abdominal segment; two recurved hooks on dorsal anal lobe.

[Described from specimens Hopk. U.S. 13548a $a^{1}$.]

Mr. H. B. Herbert collected these specimens with many adults in very decayed wood of Tsuga and Abies in California.

\section{LEPTURA CRASSIPES LCConte}

Head beset with fine slender hairs; epistoma thin; labrum trunsversely oval, anterior edge broadly rounded from posterior angle, constricted at base; mandible very shining; dorsal angle very abrupt and sharp; one transverse ocellus; last joint of maxillary palpi shortly conical, equal to second. Proeusternum shining, sternellum on anterior half and mesonotum and metanotum velvety asperate; mesosternum and metasternum tuberculate, asperate on anterior border; legs rather robust, joints short, especially the tarsal. Anterior and posterior margins of the ampullae asperate pubescent, tubercles rather irregular, contiguous, not so prominent. Spiracles oval, not strongly rimmed.

[Described from specimens Hopk. U.S. 9567.]

The described specimens and adults were collected by the author in a very decomposed log of Pinus, at Baker, Oregon, in July, 1911.

\section{LEPTURA MUTABILIS Newman}

Head, anterior perimeter dull, very finely punctured; hairs very short; labrum subrectangular, one and one-half times wider than long, anterior edge rounded from middle, flattentd in front; mandible short, little longer than width of condyles, dorsal angle shortly toothed; last joint of maxillary palpi conical, acute, much longer than transverse second; three ocelli. Spiracles sub-orbicular, strongly chitinized. Abdomen and thorax as in L. vittata.

[Described from specimens Hopk. U.S. 11861 h.]

The larvae breed in a variety of dead hardwoods.

They have been collected from Quercus, Betula, Acer, and Castanea. They pupate in March and carly April. Range, throughout the eastern United States and Canada. Observations by W. F. Fiske, H. B. Kirk, and the author. 
LEPTURA ASPERA LeConte

Scarcely distinguishable from L.mutabilis. In the two specimens examined the dorsal angle of the mandible is abrupt and the fine dull punctures on the anterior perimeter of the head do not extend back so far as on mutabilis.

[Described from specimens Hopk. U. s. $9192 \mathrm{~m}$ and $1184 \mathrm{~d}$.]

These larvae were collected and reared from dead Betula at Colorado springs, Colo., by B. T. Harvey.

\section{LEPTURA SPHAERICOLLIS Say.}

[Pl. III, fig. 9; Pl. XVII, fig. 9]

Head widest behind middle, epistoma thin; labrum narrowly rectangular, more than twice as wide as long; mandible short, cutting edge deeply emarginate, dorsal angle rounded; one small distinct ocellus; maxillary palpi slender, last joint slender, cylindric, equal or slightly longer than second. Proeusternum, sternellum, posterior areas of pronotum and mesonotum, metanotum, mesosternum and metasternum exceedingly finely asperate although feebly shining; legs very slender, tarsus attenuate. Ampullae feebly shining, impressed by two transverse folds marking off a narrowly transverse area, and an anterior transverse fold inarking off an anterior fusiform area. Spiracles very minute, orbicular, not strongly rimmed; body hairs very fine, slender, yellowish white.

[Described from specimens Hopk. U. S. 97900 and $11847 \mathrm{w}$.]

This larva has been collected in the decaying sapwood of Castanea, Prunus, Betula in North Carolina by IV. F. Fiske, H. G. Champion, and the author. It pupates during April and May.

\section{LEPTURA NITENS Forster}

\section{[Pl. XI, fig. 6; Pl. XVII, fig. 5; Pl. XXXI, fig. 7; Pl. XXXVII]}

Form much depressed; head very depressed, clothed with a few short, stiff lairs; epistoma very thin, front bearing a transverse suture behind epistoma; labrum roumdly trapezoidal, one and one-half times as wide as long; mandible very slender from outer face, dorsal angle searcely visible; ocelli absent; maxillary palpi slender, last joint very slender, shorter than second; anterior edge of hypostoma broadly fused with ventral mouth-parts. Proeusternum and sternellum shining; mesosternum and metasternum and mesonotum and metanotum dull, velvety asperate; legs very slender, tarsus attenuate. Ampullae dull, finely asperate, marked by two transverse impressed folds, and an anterior one marking off a narrowly fusiform transverse area. Spiracles orbicular, distinctly rimmed. Body hairs coarse, castaneous.

Pupa. Form as in adult, covered with very stiff, dark castaneous, subulate setae above clypeus on front and epicranium, two transverse bands on anterior and posterior margin of prothorax, and seattered ones on dise, as also on dise of metanotum, on first six abdominal segments these are coarser than the others; seventh, eighth, and ninth abdominal terga irregularly beset with longer setae, tenth with a bifureate spine.

The larval habits of this species form an exception in the genus. It is the only one, so far as known, which attacks living trees. The normal food plant is Castanea, but occasionally it is found in Quercus. The larva bores in the bast fibres of the bark, at the base of the tree or in crotches of limbs where plenty of moisture exists. The burrow is large and irregular, several larvae often extending it from different angles. It is packed with coarse, fibrous frass, which is expelled through a hole in the bark. The pupal cell is formed from an oval rim of this frass. The larval period usually extends over two seasons. The larva pupates in May and June.

This species is of much economic importance in relation to the chestnut bark disease. The larvae and adults have been collected throughout the eastern and central United States by Dr. A. D. Hopkins, W. F. Fiske, T. E. Snyder, E. B. Mason, W. S. Fisher, and the author.

\section{SUBFAMILY DISTENIINAE}

Two species of Distenia have come to the author's attention. A close study of these larvae substantially corroborates the opinion of Gahan (11) that subfamily rank or better, even family rank, has to be given to these species.

$57951-7 \frac{1}{2}$ 
In gencral form and structure they are strikingly aberrant from the usual crambycid type. This divergenee is due to the possession of a peculiar combination of lepturine and cerambycine characters, the latter, however, predominiting. The position of the occipital foramen is posterio-dorsad. All struetures on the dorsal surface conform to the type of lepturinae, and the ventral mouth structures to that of the Cerambycinae. The mandible is of the type characteristic of the Laminae. They suggest a very primitive type of crambycid larva. The peeuliar tentorial structures and the attachment of the skin of the prothorax directly to the submentum has been observed in no other cerambycids.

\section{('HARACTERIZATION OF LARVAE OF THE SUBFAMILY DISTENIINAE}

\section{The eharacters of the Disteniinae may be briefly summarized as follows:}

Head transverse, dorsal margins of the epicranial halves behind front entirely separated; oeeipital foramen posterio-dorsad; tentorium very broad, gula and hypostoma not evident.

Mandibles rather elongate from side; apex slightly proflueed, cutting edge obliquely trun(ate, short.

Epistoma not produced over clypeus, three epistomal setae.

Clypeus trapezoidal, filling spaee between dorsal condyles of mandibles.

submentum attaehed to the eollar; maxillac movable, cardo visible; maxillary articulating lobe full; palpifer small, jointlike; laeinia bornc on stipes.

Antennae frail, retractile.

Prothorax with presternum and epipleurum anteriorly fused. Epipleurum large, rectangular; eusternum not sharply defined; coxae small, widely separated, and situated at extremities of sternellum. Mesothoracic spiracles not protruding into prothorax. Legs moderate in size, weak.

Epipleurum protuberant only on last three abdominal segments; pleural disc never present. spiracles in a well-defined, elliptical, protruding region.

\section{DISTENIA UNDATA Oliver}

[Pl. IV, fig. 5; Pl. XI, fig. 7; Pl. XXX, figs. 1 and 2]

Form very clongate, slender, anteriorly depressed, posteriorly cylindrieal; prothorax relatively much wider than the other cerambycid larvae, suggesting a buprestid in general shape; integument thin, shining, very sparsely beset with short fine hairs.

Head depressed, widest about the middle, slightly tapering anteriorly and posteriorly, rather deeply embedded in the prothorax; mouth-frame darkly ehitinized; epistoma nearly straight, rather abruptly raised; elypeus and labrum thin, latter semi-elliptical, widest at base, finely and densely haired; mandibles narrow from side, about twiee as long as basal width, cutting edge short, truneate, dorsal angle slightly toothed; no ocelli; antennae conical, first and second joints short, transverse, subequal, terminal joint slender and longer; antennal ring elosed behind. Ventral mouthparts rather fleshy, densely and finely haired; palpi conieal, last joint longest; proeess of palpifer small, fleshy; lacinia short, fleshy; mentum longer than wide; labial palpi slender, terminal joint shortest; ligula large, fleshy; neither gula nor hypostomal sutures distinet.

Prothorax depressed, transversely oval; pronotum trapezoidal, widest at base, a narrow band of short hairs across anterior margin, posteriorly velvety pubeseent; presternum bearing two small, fleshy lobes on antcrior margin at base of submentum; eusternum widely trapezoidal, widest at base, posteriorly velvety pubeseent; sternellum also velvety pubescent; mesonotum, metanotum, mesosternum, and metasternum transverse, velvety pubeseent; seutal and hypoplerral areas protuberant. Legs small, slender, three distinet joints; tarsus attenuate, claw-like.

Abdominal segments very elongate, slender, cylindrical, intersegmental skin very long; ampullae widely separated, flat, transverse, dull, velvety pubeseent, present on only six segments; paraseutal and coxal lobes protuberant laterally; ninth segment longer than any other, eylindrical; anus transverse, two lobes yentral, one dorsal; spiracles small, orbieular.

Pupa. Head, pronotum, mesonotum, and metanotum covered with numerous long, slender hairs; each abdominal tergum bearing two circular groups of acute points, becoming more slender on last scgments, a long hair arises from the base of each point.

This larva feeds in the roots of recently killed hickory (Hicoria), especially those infested by hickory barkbeetles. It has also been found in Cercis and ITmus. The mines are extended in a meandering manner beneath the bark and tightly packed with coarse granular frass. Pupation occurs in the sapwood, normally two years are required to complete development. The larva assumes 
a folded position while burrowing similar to the buprestids. Adults have been observed at night ovipositing in the base of the trees.

Range, throughout eastern United States. Observations by A. B. Champlain, H. S. Barber, and the author.

\section{DISTENIA RUGISCOPIS Bates}

This larva can only be distinguished from $D$. undata by the denser and coarser velvety pubescence on pronotum and ampullae.

These specimens were collected by August Busck, May, 1911, along the Trinidad river, Panama, "under the bark of fallen trees."

\section{SEBFAMILY LAMIINAE}

The Lamiinae larvae show a greater diversity of structural characters, form, and biological habits than any other subfamily. They are all characterized by the oblong head, the sides of which are parallel or converge posteriorly. This form of the head sets them in sharp contrast to all other cerambyeids. With one exception (Michthysoma) they are all legless.

\section{CHARACTERIZATION OF LARVE OF THE SUBFAMILY LAMHNAE}

The characters of the Laminae may be briefly summarized as follows:

Head elongate, sides parallel or converging posteriorly; dorsal margins of epicranial halves behind front fused for the entire distance and jointly round behind; tentorial ('ross-arm internal in a plane at right angles to hypostoma (i.e., occipital foramen not apparnetly divided into an anterior and a posterior portion).

Mandible rather elongate, cutting edge shortly oblique, apex produced.

Epestoma not produced over clypeus, three to many setae on each side; clypeus trapezoidal, filling space between dorsal condyles of mandible; labrum transverse to cordate.

Maxillae rigid (only movable from stipes); cardo, maxillary sclerite, and submentum fused and attached for the entire distance between ventral articulations of mandible; palpifer large, distinct, bearing lacinia.

Antennae frail, short, very retractile.

Prothorax having presternum and epipleurum usually distinctly separated; eusternum distinct or indistinet; coxae indistinct, usually legless.

Postnotal fold absent. Mesothoracic spiracle protruding into prothorax. Legs absent (rarely present).

Abdomen with region surrounding spiracle not protrurling; epipleurum protruberant on from three to all segments; pleural tubercle usually bearing a chitinous pit at each extremity; hypopleurum small, coxal lobe large.

\section{KEY TO THE GENERA OF LAMIINAE}

Legs well developed; two distinet oeelli on each side of head; ninth tergum bearing two chitinous spines.

Legs absent; never more than one ocellus or one caudal spine.

Michthysoma

1. Antennal ring open belind (at least deeply angulate), biseeted by frontal sutur.......

Antennal ring closed behind, not bisected by frontal suture $\ldots \ldots \ldots \ldots \ldots \ldots \ldots \ldots \ldots \ldots$

2. Anterior margin of front normal.

Anterior margin of front bearing a transverse row of carinae.

3. Head depressed, at least twice as wide as thick.

Head thicker, not twice as wide as thick.

4. Ampullae irregularly tuberculate.

Ampullae bearing two regular rows of tubercles

5. Never both ampullae and pronotum velvety pubescent

Both ampullae and pronotum velvety pubescent.

6. Gular sutures protuberant: ninth abdominal tergum extended into an acte deflexel spine.

Gular sutures not protuberant.

7. Hypostoma transversely protuberant; front behind epistoma bearing striac extendiug from a row of punctures.

Hypostoma and front normal

8. Pronotum rugose on posterior half; ampullar tubereles very large; form robust icantholeres Pronotum either plainly striate or velvety pubeseent; tubereles of ampullae smaller; chitnious pore of pleural tuberele very small; form depressed. . Liopus and Leptostylus

Posterior area of pronotum varying from dull granulate to velvety pubescent usually only on hind margin; pores of pleural tuberele very distinct.

II yperplatys 
9. Hend widest across anterior borler; ampullae velvety pubeseent, dull. . . . . . . . .

I cad widest just bofore midlle; ampullae shining . . . . . . . . . . . . . . Nyssodrys

10. Mandibles very sender; no eandal armature. . . . . . . . . . . . . . . . A canthocinus Mandibles shorter; a flattened chitinous process on ninth abdominal tergum. . Graphisurus

11. Maxillary palpi two-jointed, or, if threr-jointed, ninth tergum bearing a long spine.Lepturges Maxillary palpi three-jointed; no caudal spine.................... Eupogonius

12. Maxillary palpi three-jointed; form clongate. .13

Iaxillary palpi two-jointed; form robust; ampullae bearing very large, irregular tuber-

cules; borly densely and coarsely hairy; breeds in the roots of Asclepias.... Tetraopes

13. Molar portion of mandible sharply toothed; pronotum normal................ Dectes Molar portion of mandible normal; anterior margin of prothorax bearing a transverse row of carinac.

Psenocerus

14. Pleural tuberclo having two distinet chitinous pits; pronotum rugulose; ampullar tubercles irregular

Pleural tubercle having no pits; pronotum smooth; ampullar tubercles in two or three

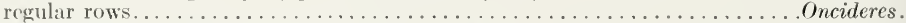

15. Gula protuberant; posterior area of pronotum fincly asperate $\ldots \ldots \ldots \ldots \ldots \ldots \ldots \ldots \ldots$

Gula not protuberant; pronotum variable . . . . . . . . . . . . . . . . . . . . 19

16. Tubereles of ampullae finely asperate; chitinous pits of pleural tubercle distinet ......17

Tubercles of ampullae glabrous; chitinous pit of pleural tubercle absent; anus two-lobed, a group of chitinous setae beneath ventral lobe...................Ptychodes

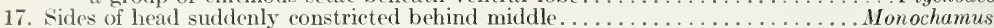

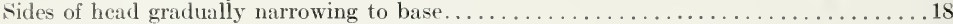

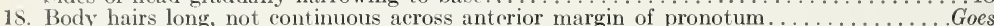

Body hairs short, rather dense, a continuous band across anterior margin of

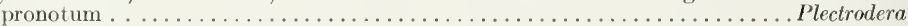

19. Chitinous pore at extremities of pleural tubercle distinct; head depressed ..........20

Chitinous pore of tubrcle absent; head variable . . . . . . . . . . . . . . . .22

20. Last joint of maxillary palpi rarely more than one-half length of penultimate; form eylindrical, dorsally hairy; ampullae strongly protuberant, several with conical papillae ; cactus feeders.

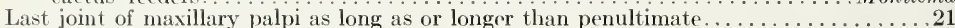

21. Hypostoma transversely bulging; ampullae normal; often a chitinous spine on ninth terga

Hypostoma normal; ampullae deeply bilobed.

Dorcaschema. Hetoemis.

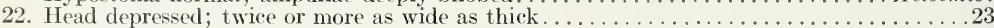

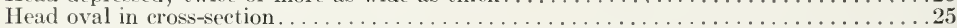

23. Posterior area of pronotum glabrous or velvety pubescent . . . . . . . . . . . . . . 24 Posterior area of pronotum coarsely asperate, as also ampullae; epipleurum protuberant on all segments; spiracles oval.

Saperda

24. Posterior area of pronotum strongly protuberant, pinnately striate; tubercles of ampullae in two regular rows; maxillary palpi two-jointed................. Cyrtinus

Posterior area of pronotum normal; ampullae obscurely tuberculate, having a deep median furrow; ninth tergum bearing a chitinous process; maxillary palpi often two-jointed

Pogonocherus and Ecyrus.

Posterior area of pronotum variable; ampullae bearing two regular rows of tubercles; no caudal armature; maxillary palpi two-jointed.

Lepturges querci (group)

25. Pronotum shining; ampullae bearing two transverse ridges or rows of tubercles; last abdominal segment swollen; spiracles orbicular. ..................... 26

Pronotum asperate, bearing two heavy oblique lateral impressions; ampullae finely asperate or irregularly tuberculate; spiracles lenticular.

26. Hypostoma protuberant in two conical processes; head less salient; all dorsal and ventral

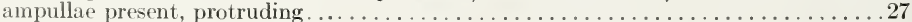

Hypostoma not protuberant; head more salient; ventral ampullae absent on all or many abdominal segments.

27. Eusternum distinet, elliptical; mesosternum and metasternum not tuberculate; last four abdominal segments bearing only one row of tubercles (posterior row); eaudal spine incurved ventrally.

Eusternum not distinct; mesosternum and metasternum tuberculate; ablominal ampullae all bearing two rows of tubercles; caudal spine directed straight backward.... Ataxia

28. Pronotum entirely smooth, lateral sutures not impressed; mandibles bifurcate at apex; sternellum distinct; all ventral ampullae absent; no caudal spine.......... Hippopsis

Pronotum posteriorly embossed, faintly striate, lateral sutures impressed; mandibles normal; eusternal and sternellar areas fused; latter posteriorly projecting; ventral ampullae present on sixth and seventh segments; ninth tergum bearing a projecting process.

Spalacopsis

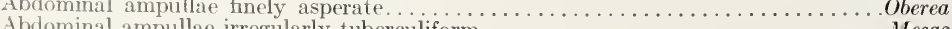

Abdominal ampullae irregularly tuberculiform $\ldots \ldots \ldots \ldots \ldots \ldots \ldots \ldots \ldots \ldots \ldots \ldots \ldots$ Mecas 
MICHTHYSOMA LeConte

This larva, from the material at hand, strongly suggests the Aseminae, especially the genus Opsimus. In fact, the writer believes that it should be placed in this position. However, since the characterization is based only on the larval skins, it is retained where the adult systematists have placed it.

The head structure cannot be definitely determined, but the two-jointed maxillary palpi, the presence of well-developed legs, the bilobed prominent ampullae and the Atimia-like caudal spines all strongly suggest affinities to the Aseminae.

\section{MICHTHYSOMA HETERODOXUM LeConte}

[Pl. V, fig. 2; Pl. II, fig. 12; Pl. XII, fig. 8; Pl. XXIV, fig. 10; Pl. XVII, fig. 15; Pl. VII, fig. 10]

Form semi-robust, slightly tapering posteriorly; integument thin, shining, very sparsely clothed with rather stiff yellowish-brown hairs.

Head depressed, about as wide as long, sides subparallel; mouth-frame corneous; epistoma straight, thin; elypeus trapezoidal; labrum about twiee as wide as long, anterior margin broadly curved; mandible slender from side, smooth, apical angle rounded, eutting-edge oblique, dorsal angle rounded, deflexed or sometimes abruptly toothed; antennae very small, two-jointed, with a small supplementary joint; antennal ring not open behind; two prominent white ocelli placed below antennae. Ventral mouth-parts not strongly chitinized, fused for entire width of hypostoma; joints of maxillary palpi subequal, last shorter than last labial, ligula broad, distinet ; gula not distinct, anterior margin confluent with submentum.

Prothorax transverse, widest in front; a yellowish band, divided in middle, extending across anterior dorsal margin; pronotum entirely smooth, shining, lateral sutures entire, bearing a few seattered hairs; eusternal area distinet, roundly trapezoidal, smooth, shining. Legs welldeveloped, two-jointed, seeond twice length of basal, tarsus attenuate, longer than sceond joint.

Abdomen bearing very prominent, shining ampullac, these deeply bilobed and transversely marked by two impressions, somewhat suggesting large tubereles. Ninth tergum armed with two conical, acute spines, separated somewhat more than their height.

[Described from specimens Hopk. U. S. 9784x.]

The larvae were collected in the dead sapwool of hickory stumps (Hicoria) at Cedar Mountain, N.C., and reared April 15, 1913, by the author.

MONILEMA Say.

[Pl. XXIX, fig. 5]

Cylindrical, robust, coarsely haired species; heat depressed, sides parallel, broadly rounteel posteriorly; clypeus and labrum thick, latter about twice as wide as long; mandible seareely tapering, about twice as wide as basal width, eutting edge short, roundly emarginate, outline similar to Wichthysoma; antennal ring entire. Ventral mouth-parts fleshy; nentum distiuct from submentum, narrowly transverse, not sunken; chitinization entire across base of labial stipes; last joint of maxillary palpi minute, scarcely one-half the length of second. Posterior area of pronotum narrowly transverse, four times as wide as deep, limited anteriorly by a short impression at each side, often bearing numerous short hairs; dorsal abdominal ampullae irregularly tubereulate or covered with conical palpillae, strongly projeeting and deeply bilobed, lraving a single transverse impression, epipleurum protuberant on all segments, tuberele broadly oval, bearing many setae but lacking the chitinous pore at each extremity; spiracles orbieular, peritreme distinet; no caudal armature.

[Described from six specimens in the U.S. National Museum labelled: Eneinal, Texas, April 11, 1908, J. D. Mitchell, Colr.; Brownsville, Tex., Jume 8, 190s, C. R. Jones and F. C. Pratt; Texas, F. C. Pratt; Austin, Nev., April 23, 1908.]

A number of specimens of this genus representing several species have been studied, but none have been reared so as to establish their specific identity. One collected by Hubbard, No. 827, labelled $1 /$. giganteum (?), differs from the above in having chitinous asperities on the ampullae and pronotum. so far as known, all feed in the stems of cactus and to this peculiar enviromment the body has become well-adapted. The texture is coarse, covered with stiff hairs, and the ampullae are often covered with projecting papillae. The living larvae strongly suggest some Scaraebidae, often assuming the curved form of body. They superficially more closely resemble the larva of Tetraopes than that of any other Lamiinae. This probably is a development due to similar methods of feeding. 
PLEGTRURA Mannerheim

The form of the adult would suggest something more aberrant than the true lamine type of larvae. It is in no way suggestive of Monilema, but most alosely resembles symaphoete. The peculiar extension of the last tergum into at pointed process is the most distinctive characteristic.

\title{
PLECTRURA SPINICAUDA Mannerheim
}

\author{
[Pl. XXIV, fig. 2; Pl. XV1I, fig. 16; Pl. VII, figs. 6 and 7]
}

form depresserl, elongate, sides parallel; integument firm, shining,sparsely clothed with long, finc, whitish pubeserence.

Ilead depressed, sides suddenly constrieted near base; epistoma straight; labrum roundly rectangular, about one and one-half times as wide as long; mandible about twice as long as basal width, dull granulate, cutting-edge obliquely truncate, apex truncate; antennal ring open behind; one pair of prominent ocelli. Tentral mouth-parts not chit inized; mentum twice as wide its long, distinet from subment $1 \mathrm{~m}$; maxillary palpi slender, ultimate joint sharply conical, longer than either first or second, slightly longer than last labial; lizula large, fleshy, cylindrie; gular sutures distinet, slightly protuberant.

Prothorax trapezoilal, slightly wider behind; pronotum with lateral sutures undefined, entirely glabrous, shining, very finely rugulose; eusternum triangular, distinct, smooth, shining. Mesonotum smooth, shining; metanotum, mesosternum, and metasternum tuberculate.

Abdomen depressed; epipleurum distinctly protuberant on all segments, tubercles oval bearing two long setae and a chitinous pore at each extremity; ampullae seven, shining, beset with two rows of irregular tubercles. Ninth segment gradually extended into a sharp, short, deflexed spine. Spiracles orbicular. Anus trilobed.

[Described from specimens Hopk. U. S. 4203a.]

This larva has been collected and reared from Alnus and Rhammus in Washington State by H. E. Burke. The larva mines under the dead wet bark, pupating from May to July in the sapwood.

\section{SYNAPHOETA Thomson}

The pronotum, the tubereulation of the ampullae, and the protuberant epipleurum on all segments resemble those of Plectrura. Perris (25) describes and figures the related European species Mesosa nubila. Both these species, so widely separated geographically, have the peculiar longitudinal striae on the epistoma and the protuberant hypostoma. The larvae are very similar in other respects also.

\section{SYNOPIIOETA GEUXI LeConte}

\section{[Pl. XIII, fig. 9; Pl. XVI, fig. 16]}

Form robust, slightly depressed; integument firm, shining, sparsely clothed with long, slender, golden hairs.

Head depressed, sides suddenly constricted behind; mouth-frame heavily chitinized; epistoma nearly straight, distinct, smooth, bearing four pairs of deep setigerous punctures from each of which extends posteriorly a series of fine striae; labrum about twice as wide as long, widest behind, densely haired; mandible short, robust, dull black, about one and one-half times at long as basal width, cutting edge obliquely emarginate; antennal ring open behind; one pair of distinct ocelli. Ventral mouth-parts rather strongly chitinized; mentum not entirely distinct; palpi rather slender, conical, last joint of maxillary shorter than others, about equal to last labial; ligula very large, cylindrical. Hypostoma transversely protuberant behind; gula, a faint white line.

Prothorax depressed, rather strongly chitinized, widest behind; pronotum having lateral sutures impressed behind, entirely glabrous, smooth, shining, except for an anterior border of hairs; sternum anteriorly coarsely hairy, laterally smooth, chitinized; eusternum not distinct. Mctanotum, mesosternum, and metasternum tuberculate.

Abdomen bearing seven pairs of ampullae, dorsally with two or four irregular rows of large tubercles, central ones largest. Epipleurum strongly protuberant on all segments, tubercles orbicular, small, having two setae and one chitinous pore on ventral margin. Last tergum bearing a very minute chitinous tubercle, Anus trilobed.

[Described from specimens Hopk. U. s. 9587.]

This larva feeds in dead and dying wood of Salix and Acer throughout the Pacific Coast region. The burrows are large, extending through the sapwood 
and heartwood and loosely filled with fibrous frass. The writer found them ovipositing in Salix dying from the attack of Saperda hornii, in August, 1911, at Walker, Oregon. The adult gnaws through the bark before ovipositing. Observations by G. Hofer, F. B. Herbert, and the author.

\section{Group MONOCHAMIDES}

The following genera are all closely allied and can be distinguished by the following characters:

Head depressed; gula distinet and protuberant; antennal cavity closed behind; posterior area of pronotum finely velured or asperate; ampullae bearing dorsally four rows of tubereles usually velured or asperate; epipleurum strongly protuberant on all except first two segments, tuberele having one or two chitinous pits.

The larvae feed for a short time beneath the bark, later going into the wood, where they either feed for several years as in Goes, Ptychodes, and Plectrodera, or only to construct short mines and pupal cells as in Monochamus.

\section{P'TYCHODES TRILINEATUS Linnæus}

\section{[Pl. V, fig. 5; Pl. XXIII, fig. 7; Pl. VII, fig. 15]}

Form large, elongate; integument firm, shining, beset with rather stiff brownish hairs.

Head depressed, about one and one-half times as long as wide, sides gradually tapering behind; mouth-frame heavily chitinized; epistoma straight, abruptly raised; labrum roundly rectangular, about one and one-half times as wide as long, anterior half densely hairy; mandible about twice as long as basal width, dull, black, cutting-edge obliquely emarginate; antemal ring entire; one pair of distinct ocelli. Ventral mouth-parts somewhat chitinized, palpi slender, each maxillary palpal joint successively longer from base outward, last shorter than last labial, one-half length of first labial; ligula cylindrical, prominent; lacinia eylindrical, fleshy; mentun not distinctly defined; hypostoma heavily chitinized; gula protuberant.

Prothorax rectangular, depressed; pronotum defined posteriorly by lateral impressions, anteriorly light yellowish, shining, with an anterior border of hairs, posteriorly densely velvety pubescent, spotted with minute lenticular glabrous spots; sternum anteriorly hairy, laterally yellowish, chitinized; eusternum shining, sparsely haired. Mesonotum anteriorly velvety pubescent, posteriorly shining; metanotum, mesosternum, and metasternum tuberculate. Legless.

Abdomen having seven pairs of well developed ampullae, these transversely oval, bearing dorsally four irregular rows of shining tubercles, ventrally two. Epipleurum distinctly protuberant on all segments, tuberele rectangularly oval, bearing four to five setae, no chitinous pores. Spiracles large, oval, chitinous rimmed. Anus transverse, two-lobed, the lower one bearing beneath a group of five to eight short, acutely subulate setae or spines.

[Described from specimens Hopk. U. S. 10543a.]

The larva feeds in living branches and trunks of Ficus, Almus, and Worus often killing the trees. The work and habits resemble those of foes. It occurs along the Gulf States into the southwestern United Ftates and Mexico. Observations by M. Chrisman and W. D. Edmonston.

\section{MONOGHAMUS Serville}

Head strongly depressed, sides suddenly constricted behind middle; mandible slenter, about three times as long as condylar width; antennal ring entire; nentum distinct from submentum; gula protuberant. Posterior area of pronotum finely asperate; dorsal abdominal ampullae bearing four rows of finely asperate tubereles. Epipleurum protuberaut on all segments; pleural tubercle elongate oval, having a chitinous pit at each extremity and three or more setac. spiracles oval.

The species of Monochamus are characteristically pine (Pinus) feeders, but in the northern part of the range are common in Picen and Abies. Mr. R. Hopping tells me that in British Columbia the larvae are not common in Pinus ponderosa. The eggs are laid in recently dead, dying, or living (mamorator) trees. The female gnaws an irregular hole through the bark, inserting from one to six eggs. The larvae feed from one to two nontlis between the bark and wood, and during this time they are very much depressed. The entire bark is loosened from the wood and this space is packed with long fibrous frass. 
Inter the larva enters the wood through an oval hole, which soon becomes circular as the larva fills out. This chamber is construeted into the pupal cell. It is usually cxtended parallel to the grain, and then upward to the bark, several inches from the point of entrance, making a U-shaped cell. After pupation the adult cmerges by gnawing through the bark. In more northern parts of the range two years are required to complete the life cycle. Rarely the larva will make a Rhagium-like pupal cell between the bark and wook A dipterous (tachinid) parasite commonly attacks these species, killing them in the pupal cells.

The adult beetles feed extensively before ovipositing on the needles of conifers. Scutellatus and marmorator liave been observed gnawing off the bark on small twigs, many of which later die. The red foliage of balsam on these twigs is a very characteristic feature. On spruce trees surrounding logging operations sufficient branches are sometimes killed to cause serious defoliation and malformation of the trees.

\section{KEY TO THE KNOWN SPECIES OF LARVAE OF MONOCHAMUS}

Dorsal anal lobe decidedly protruding posteriorly.

Dorsal anal lobe not decidedly protruding posteriorly.

Tubercles on ventral ampullac glabrous.

I. titillator

Tubercles on ventral ampullae beset with fine asperities.

Matured larvae more robust, hairs coarse, a continuous band of hairs across anterior

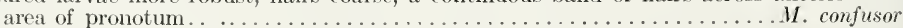

Matured larvae less robust, hairs finer, the band of hairs not continuous across pronotum.

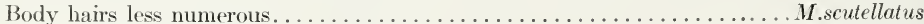

Body hairs more numerous (See description).................. marmorator

MONOCHAMUS TITILLATOR Fabricius

[Pl. VII, fig. 12]

Form very elongate, slightly depressed; integument firm, shining, rather densely clothed with yellowish brown hairs.

Head strongly depressed, suddenly constricted behind middle; labrum roundly oval, slightly wider than long, densely hairy in front; antennal ring entire; mandible slender, about three times as long as basal width, cutting edge broadly emarginate. Ventral mouth-parts rather strongly chitinized; mentum distinet, one and one-half times as wide as long; palpi slender, joint of last maxillary acute, shorter than sceond or last labial; gula protuberant.

Prothorax depressed, rectangular; posterior area of pronotum velvety asperate, spotted with small glabrous areas, anteriorly glabrous and having a dense group of hairs at anterior extremities. Mesonotum anteriorly dull pubescent, posteriorly shining; metanotum tuberculate; mesosternum and metasternum bearing two transverse rows of velvety asperities on broken tubercles.

Abdomen depressed; dorsal ampullae bearing four rows of tubercles, these more or less confluent in the middle, and all asperate pubescent; ventral ampullae bearing two rows of tubcreles. Epipleurum protuberant on all segments; pleural tubercle elongate oval, bearing a chitinous pit at each extremity and about ten setae. Spiracles oval, chitinous rimmed. Dorsal anal lobe large, projecting posteriorly beyond others.

Pupa: Form as in adult; antennae folded over wing in several coils. Beset with acute chitinous spines as follows: Groups on front of head and labrum, and on anterior margin, dise, base and lateral tubercles of protergum; two converging rows on mesonotum and metanotum; two transverse bands on posterior border of first six abdominal segments. Last abdominal deeply divided beneath, dorsally projecting into a large acute, chitinous-tipped process.

This species, commonly known as "the southern pine sawyer," has been found from Maine south through Texas. It is very destructive to stormfelled trees, in one season's time often rendering the timber practically valueless. In the extreme south several generations occur each year. Webb (34) gives a detailed account of the habits and economic status of this species. 


\title{
MONOGHAMUS SGUTELLATUS Say
}

\author{
[P]. XIII, fig. 5; Pl. XXIII, fig. 8, Pl. XLIII]
}

Distinguishable from titillator by the fact that the dorsal anal lobe does not project perceptibly, and from confusor by characters given in key.

Pupa. Distinguished by the smaller, though similarly disposed, spines except that the transverse band across the anterior border of the protergum is lacking.

Including the western variety, this species occurs throughout the northern pine-growing regions of the United States and Canada. It feeds in Pinus, Picea and Abies. Its habits are similar to $M$. titillator. In Massachusetts it has been found commonly pupating between the bark and wood.

\section{MONOCHAMUS CONFUSOR Kirby}

The dorsal anal lobe does not noticeably protrude; the body hairs are coarse, resembling titillator. Distinguished from scutellatus by the fact that the two groups of hairs on the anterior lateral angles of the pronotum extend in a less dense though continuous band across the area.

Pupa. Distinguished by the almost total absence of spines on the protergum.

A northeastern species, common throughout the higher mountains of West Virginia, north into Canada. As far as known, it attacks only Pinus strobus. Packard (23) and Hopkins record this species attacking living balsam fir (Abies balsamea) at Brunswick, Maine, probably confusing it with marmorator.

\section{MONOCHAMUS MACULOSUS Haldeman}

Dorsal anal lobe not protruding; tubereles of ventral ampullae glabrous, not bearing fine asperities.

[Described from specimens Hopk. U. S. 12593.]

This species occurs throughout the western United States and Canada, attacking all species of the western pines (Pinus). Habits similar.

\section{MONOCHAMUS MARMORATOR Kirby}

This larva is very difficult to separate from scutellatus. In the earlier stages the asperities are much coarser on the pronotum and ampullae. Matured larvae are considerably more hairy, the tubercles on the ampullae are broader and less projecting and the abdomimal spiracles are nearly orbicular with a very heavy peritreme usually more darkly coloured. The hairiness can be expressed by comparison of the group of hairs at the extremity of the lateral suture of pronotum (see "a" fig. S, Pl. XXIII). In scutellatus this group varies from 6 to 10 , while in marmorator from 12 to 20 .

[Described from specimens No. 15041 Dominion Entomological Branch.]

This insect is of much economic importance in balsam following spruce budworm outbreaks in eastern Canada and northeastern United States. It attacks the defoliated and weakened trees, causing their death. The adults are active at night, ovipositing under the balsam pustules on the trunk. The large egg punctures and copious flow of balsam from the wounds are very characteristic features of their attack The larval mines are more transverse than other species, thus more quickly girdling the tree. A more detailed discussion of the habits will be published later.

\section{GOES LeConte}

Head strongly depressed, sides very weakly constricted behind middle; mandible robust about twice as long as condylar width (seen from side); antennal ring entire; mentum distinct from submentum; gula protuberant (less pronoumced than in Yonochamus). P'osterior area of pronotum finely asperate, dense group of hairs at anterior lateral angles absent; dorsal ampullae bearing four rows of tubercles, these finely asperate except in oculata. Epipleurum protuberant, on all abdominal segments; pleural tubercle broadly oval, bearing a chitinous pore at each extremity and rarely more than two setae. Spiracles oval. 
The species of fores are assentially less hairy than those of Monochamus. The degree can be best melicated by the dense group of hairs on the anterior area of the pronotum being reducel in fios to a rery few. The asperate area of the pronotum is deeply notehed by a right angle at the anterior lateral extremities. These asperities do not extend forward over the impression (in this noteh) made by muscular attachments, as they do in Monochamus.

These larvac are all hardwood feeders. They all attack living trees, exeept oculatus, mining beneath the bark a very short time and exeavating large mines deep into the heartwool. The larval stage extends over a period of from two to four years. At the point where the egg is laid an opening is maintained throughout the larval existence from which fibrous frass is extruded. Pupation oceurs at the top of the larval mine deep in the heartwood, the adults gnawing out through the intervening sapwood and bark.

The much stronger veluring, or rather asperities of pronotum and ampullae is well contrasted with that of the larvae of Monochamus, which attack only dying trees. One species, a dead-wood feeder, $G$. oculatus, has not the ampullae so covered.

\section{KEY TO THE SPECIES OF GOES}

Tubercles of ampullae covered with fine asperities; breeds in living trees.

Asperities on ampullae coarse, individual points visible with a hand lens.

Asperities on prosternellar area in a continuous transverse band; breeds in trunks and branches of Quercus.

G. tigrinus

Asperities on prosternellar area broken for a short distance in middle breeds in the base or roots of Quercus.

Asperities on ampullae finer, individual points not visible with hand lens.

First thoracic spiracles twice or more as long as wide; body hairs reddish brown; breeds in

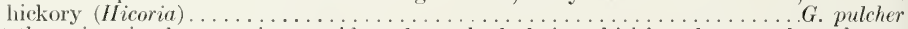

First thoracic spiracle not twice as wide as long; body hairs whitish or lemon-coloured.

Median oval of tubereles on ampullae three or four times as wide (transversely) as long: breeds in the stems and large branches of Quercus, Fagus, Carpinus and

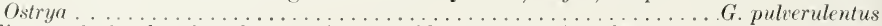

Median oval of tubereles about twice as wide as long, breeds in the small branches

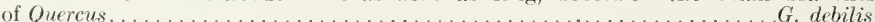

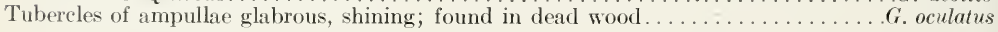

\section{GOES TIGRINUS DeGeer}

[Pl. II, fig. 2; Pl. XXIV, figs. 11 and 12; Pl. XVI, fig. 12; Pl. XXVIII, figs. 1 and 3; Pl. XXXIII, fig. 1; Pl. XL, fig. 3, Pl. XLIII]

Form subcylindrical, elongate, robust; yellowish-lemon tinged; integument tough, shining, vely sparsely clothed with coarse brownish-yellow hairs.

Head strongly depressed, side slightly constricted behind middle; labrum transverse, widlest behind, slightly notched in front, densely haired on anterior half; mandible robust, from side not twice as long as condylar width, cutting edge obliquely emarginate; antennal ring entire; one pair of distinct ocelli. Ventral mouth-parts rather chitinized; palpi slender, last joint of maxillary palpi acute, shorter than last labial; anterior edge of hypostoma broadly curved; gula protuberant.

Prothorax rectangular, depressed, strongly so anteriorly; pronotum anteriorly smooth, posteriorly very finely asperate pubescent; eusternum well defined, a group of hairs in centre; sternellum entirely finely asperate. Mesonotum smooth or anteriorly finely asperate; metanotum, mesosternum, and metasternum tuberculate, these asperate pubescent.

Abdomen nearly cylindrical; dorsal ampullae bearing four rows of asperate tubercles, the ventral two rows; epipleurum protuberant on all segments; pleural tubercle broadly oval to roundly rectangular, bearing a chitinous pit at each extremity and two setae. Spiracle oval, strongly chitinized.

Pupa. Body beset with yellowish-brown bristles, those of abdominal terga arranged in two very prominent, closely sot blotehes; last segment armed with a strong, recurved, chitinous spine, bearing several minute teeth on the margins.

[Described from specimens Hopk. 12666, 11839, and 12673.]

This species has only been taken in Quercus and very rarely in any except the white oaks. The life cycle extends over a period of four years. It occurs through the eastern and central United States. 


\section{GOES TESSELATUS Haldeman}

This species is distinguished from tigrinus by the asperities of the prosternellar area not being continuous across the fold but broken in the middle.

Pupa. Can be distinguished from tigrinus only by the coarser and darker eoloured bristles of the body; those of the pronotum are about twice as numerous.

[Deseribed from specimens Hopk. U. s. $9785 f^{1}$.]

This larva bores in the base of young Quercus saplings and rarely in Castanea and Amelanchier. Often the entire base of the tree is hollowed out, causing its death. It occurs throughout the eastern and central United States.

This material and biological notes were furnished by Mr. Fred E. Brooks, of the Bureau of Entomology, United States Department of Agriculture.

\section{GOES PULCHER Haldeman}

In general similar to tigrinus, but the asperities of the pronotum and the ampullae are much finer and the tubercles of the ampullae not so prominent; body clothed with coarse reddishbrown hairs; median oval of tubercles on dorsal ampullae three to four times as wide as long; first thoracic spiracle twiee as wide as long; living, matured larvae of a distinct yellowish eolour.

Pира. Similar to pulverulentus but with fewer bristles on labrum and pronotum; those of sixth abdominal tergum very few and sparser than on first.

[Deseribed from speeimens labelled Annandale, Mil., July 23, 1915.]

The larva had been found only in hickory (Hicoria). The eggs usually are laid in crotches of branches and the larvae feed a greater porportion of the time under the bark. They mature more rapidly than most other species of the genus, requiring two or three years to complete the life cycle. Found throughout the eastern and central United States and southern Canada.

\section{GOES PULVERUlentus Haldeman}

\section{[Pl. XII, figs. 5 and 6 , Pl. XLIV]}

Distinguished from pulcher only by the finer, light lemon-eoloured hairs on the body and by the faet that the thoraeie spiracles are more broadly oval, not twice as wide as long.

Pupa. Bristles arranged in two groups on anterior portion of labrum; front of head sparsely covered; pronotum sparsely beset with shorter bristles; mesonotum and motanotum bearing two irregular blotehes of still shorter ones; first six abdominal terga beset with two transverse bands of short, dense, reddish bristles, those of sixth seareely sparser than the first; last tergum extending dorsad in a fleshy triangular process, suddenly acutely eonical and elitinous tipperl.

[Deseribed from specimens Hopk. U. S. 11867a.]

The larva has been found in the main stems of smaller trees or the branches of larger trees of Fagus, Carpinus, Ostrya, Quercus, CTmus, and Platanus. The life cycle is normally completed in four years.

\section{GOES DEBHLIS LeConte}

Resembles pulverulentus, but has still finer and lighter eoloured body-hairs; the thoracie spiraele is not twice as wide as long and the median oval of the ampullae is little more than twice as wide as long.

Pupa. Similar to pulverulentus exeept that the bristles are finer and on labrum and front of head they are less numerous.

[Described from speeimens Hopk. U. S. 11 sos.]

This larva has only been found in the lateral branches, from one-half to one inch in diameter, of oak trees (Quercus). The life cycle normally is completed in two years.

\section{GOES OCULATUS LeConte}

[Pl. Y, fig. S.]

Integument thin, shining; borly sparsely eovered with whitish silky hairs. Gula distinct but seareely as protuberant as in other speeies; mandible more slenter; posterior area of pronotum eovered with velvety pubescenee; anpullae tubereulate, the tubercles smooth and shining pleural tubercle orbieular; spiracles small, broatly oval.

[Described from speeimens Hopk. [.. S. 9789k.] 
This is the only species of the gems which does not attack living trees. It foeds bencath the bark, going into the wook to pupate. It is found in the dead wool of Cornus, Oxydendron, Fagus, and Castanea throughout the eastern States, but more commonly south. Observations by A. D. Hopkins, W. F. Fiske, and the author.

\section{PLECTRODERA SCALATOR Fabricius}

Form robust, cylindrieal; integument very thin shining, rather densely covered with short, golden-brown hairs.

Head as foes, but the mouth-frame much more heavily ehitinized and the anterior edge of hypostoma thickened so as to almost obscure the gula. Pronotum anteriorly bearing a contimuous transverse row of short golden brown hairs, posteriorly velvety pubescent; eusternum beset with short hairs evenly distributed on anterior half; sternellum velvety pubescent for entire width. Anpullae bearing four rows of very fine velvety pubescent tubereles, these tubereles almost obsolete; pleural tubercle broadly oval, bearing a number of short hairs and two ehitinous pits; spiracles broadly oval, a little larger than antennal ring; peritreme heavy.

This larva resembles that of Goes in all essential characters. It is distinguished from species of that genus by the short, golden-brown hairs, which are much more thickly set. The anterior margin of the pronotum bears a continuous transverse band of hairs.

These specimens were collected from the base of living Populus by F. B. Milliken, Garden City, Kans. Mr. Milliken (21) has described the seasonal history and the injury to cottonwood caused by these larvae. The habits are very similar to those of Goes.

\section{DORGASGHEMA LeConte}

The genera Doraschema and Hetoemis have been placed in the group Monochamides by LeConte and Horn, but Lacordaire retains them in a separate group, Dorcaschemides, which seems to be justified by the larvae. These species have no essential larval characters in common with the genus Monochamus. The larvae of Hetoemis also suggest affinities to Dectes, and this relationship has been indicated by Gemminger and Harold.

Head depressed, sides not sensibly constricted behind middle; mandible short; hypostoma transversely bulging; mentum distinet, sunken; antennal ring entire; palpi very slender, attenuate. Posterior area of pronotum shining, smooth to finely reticulated; eusternum not distinct; pleural tubercle bearing a very small, chitinous pit at each extremity; dorsal abdominal ampullae bearing only two rows of irregular tubercles. Epipleurum protuberant on last three segments. Anal spine present or absent.

\section{KEY TO THE SPECIES OF DORCASCHEMA}

Dorsal anal lobe unarmed; posterior area of pronotum smooth. Lives in hickory.....D. nigrum Dorsal anal lobe bearing a chitinous protuberance; posterior area of pronotum reticulate.

Lives in mulberry (Morus).

(hitinous proeess laterally eompressed.

D. alternatum

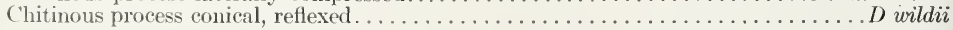

\section{DORGASGHEMA NIGRUM Say.}

Form elongate, subeylindrical; integument rather firm, shining, sparsely clothed with yellowish-white hairs.

Head depressed, sides scarcely constricted behind middle; epistoma straight, rather abruptly declivous; labrum thin, fungiform, but little wider than long, anterior margin densely ei'iate; mandible short, about one and one-half times as long as basal breadth, dull black, cutting-edge obliquely truncate; antennal ring entire; one pair of white oeelli. Ventral mouth-parts rather extended, hairs very fine; mentum twice as wide as long, sunken, distinct; palpi slender, maxillary longer than laeinia, last joint of maxillary equal to second, slightly longer than last labial; anterior edge of hypostoma thin, curved, hypostoma transversely bulging; gula not distinct.

Prothorax trapezoidal, depressed, widest behind; pronotum entirely smooth, shining, or very indistinctly longitudinally striate, lateral sutures impressed behind, anteriorly a group of fine hairs at each side. Mesonotum smooth, shining; metanotum, mesosternum, and metasternum tuberculate. 
Abdomen cylindrieal; ampullae sensibly bilobed, dorsal and ventral with two rows of irregular tubereles divided along median line; pleural tuberele elongate rectangular, a chitinous pore at eaeh extremity; epipleurum protuberant on last three segments. Spiracles orbicular, distinctly rimmed.

[Described from specimens Hopk. U. s. $9784 b^{3}$.]

This species has been collected only from dead hickory (Hicoria) branches throughout the eastern United States. The larvae feed between the bark and wood, making a curved pupal cell in the sapwood and emerging by a hole at the opposite end from which it entered the wood. The adults emerge during May and June. Based on observations of A. D. Hopkins, J. L. Webb, A. B. Champlain, and the author.

\section{DORGASCHEMA ALTERNATUM Say.}

Distinguished from nigrum by the compressed chitinous protuberance on the dorsal anal lobe; the hairs on the body are finer; the labrum is slightly longer and less sparsely eiliate; posterior area of pronotum very finely and irregularly striate to retieulate; tubereles of ampullae less confluent.

Pupa. Form as in adult; remarkably glabrous, except for eight to ten small chitinous points on posterior edge of dorsal abdominal segments; last segment bearing a eonieal, acute reflexed spine.

[Deseribed from specimens Hopk. U. S. 5829 and $9791 \mathrm{~m}$.]

The larva feeds exclusively in mulberry (Morus) branches, sometimes attacking green limbs that have been slightly injured. Habits otherwise similar to those of nigrum. Adults fly throughout May and June. Observations by A. D. Hopkins, J. L. Webb, A. B. Champlain, and the author.

\section{DORCASCIIEMA WILDII Uhler}

[Pl. XXIV, fig. 9; Pl. XVI, fig. 2; Pl. VII, fig. 9]

Matured larvae much larger and more robust than those of other species of the genus; anal process conical, blunt (not compressed), but suddenly eonstricted above base; posterior area of pronotum distinctly retieulated; mandible deeply notehed or emarginate at apex.

[Described from specimens Hopk. U. S. 12807.]

Dr. A. D. Hopkins records this insect as eausing the death of small living mulberry trees (Morus) at Kanawha Station, W. Va., Sept. 25, 1898. The larvae were working in healthy bark 2 feet above ground. Another record from the Bureau of Entomology files, by J. G. Barlow, in Missouri, Mar. 16, 1887, contains similar observations. This species feeds also in osage orange (Toxylon).

Range: Throughout the eastern and central United States.

HETOEMIS CINEREA Olivier

[P1. V, fig. 1]

Form slender, tetragonal, slightly tapering; integument thin, shining, very sparsely clothed with fine whitish hairs.

Head slightly depressed, sides rapidly narrowed posteriorly and slightly anteriorly, constricted behind middle, widest just before middle; epistonı thin, slightly curved; labrum widest at middle, anterior margin broadly rounderl, densely and fincly ciliate; mandible rather slender from side, about twice as long as basal width, strongly eurved; eut ting edge obliquely emarginate; antennal ring closed; one pair of oeelli; ventral mouth-parts fleshy; mentum distinet, one and one-half times as wide as long, sunken; last joint of maxillary palpi very slender, equal to seeond and last labial; ligula large; liypostoma rather strongly transversely protuberant.

Prothorax trapezoidal, thick, widest behind; pronotum posteriorly smooth, shining or very finely rugulose, having lateral angles elothed with fine whitish hairs; sternum anteriorly regularly and finely hairy; eusternum not distinet, glabrous, shining. Mesonotum glabrous, shining; metanotum, mesosternum, and metasternum tubereulate.

Abdomen slender, ampullae bearing two irregular rows of tubereles, third, fourth, fifth, sixth and seventh very deeply bilobed, forming two projecting lobes and giving body tetrahedral form; epipleurum protuberant only on last three segments; pleural tubercle elongate, having two large, distinct, chitinous pits and one long slender seta. Spiraeles small, nearly orbieular. No caudal spine.

[Described from speeimens Hopk. U. S. $9784 b^{2}$.] 
The larva mines for the greater part of the time uncler the bark, going into the wool, often quite derply, to make a long, eurved pupal eell, closed at both ends hy a plug of fibrous frass. Larvae have been collected from Hicoria, Cellis, Morns, and Titia. The adults are found throughout the eastern United sitates during July and Jume.

II re again oc'ur in the Lamiinae the peculiar bilobed ampullae and similar devolopment of the abdominal areas found in all subfamilies excepting the Prioninae. For example, Atimia in the Aseminae; Heterachthes in the Cerambucinac, and Encyclops in the Lepturinae. The food habits among these are radically different, however, and the character scems to have no taxonomic significanece.

\section{Group ACANTHODIDES}

The genera Acanthoderes, Leptostylus, Liopus, Lepturges, Dectes, Hyperplatys, Graphisurus, Nyssodrys, Certographus, and Acanthocinus probably do not comprise a natural group, yet the characters merge into one another so that it is difficult to draw any line of separation. The Acanthocinus-like form seems to be most distinct.

A canthoderes has very large, irregularly arranged tubercles on the ampullae, and a ruglose pronotum. Leptostylus, Hyperplatys, and Liopus have similar ampullae though small tubercles, but the pronotum is smooth or velvety pubescent. Lepturges has the tubercles arranged in two regular rows. In this genus appear two distinct species groups, those with normal palpi and a chitinous spine on last tergum, and those with two-jointed maxillary palpi and no spine. Dectes in form alone is quite aberrant. As it is cylindrical, even to the thickening of the head, it departs from the usual depressed type, but this is no doubt due to its peculiar food habits. All of the foregoing genera have the antennal ring plainly bisected by the frontal suture, while in Graphisurus, Acanthocimus, and Nyssodrys it is only angulate behind; but this is probably due to the heavy chitinization of the head obscuring the suture, which is distinct in Certographus. These last genera also all have the velured pronotum. Vyssodrys suggests Leptostylus, and both it and Graphisurus have caudal armature.

The food habits are quite as variable as the anatomical characters.

\section{ACANTHODERES Serville}

Robust species; head depressed, slightly constricted before middle; mandibles relatively short; antennal annulae open; mentum sunken into submentum, not distinct at base; gula indistinct. Pronotum posteriorly rugulose; ampullae bearing two rows of large irregular and confluent tubercles; epipleurum distinct only on last segments; pleural tubercle oval, bearing two or three setae and two chitinous pores. Spiracles large, orbicular.

The species of Acanthoderes can be considered as deadwood feeders; all except morrisii feed exclusively in any hardwood which has reached a certain stage of decay. The wood must be soft and pulpy, usually decomposed by fungi. The larval mines are extended between the bark and wood and are not very extensive. The pupal cell is shallow and constructed in the outer sapwood. A coarse fibrous wad of frass protrudes. The four species can be separated as follows.

\section{KEY TO THE SPECIES OF ACANTHODERES}

Pronotum shining, rugulose, dead-wood feeders.

Mandibles about twice as long as basal width; eastern.

Labrum sparsely hairy, these hairs whitish $\ldots \ldots \ldots \ldots \ldots \ldots \ldots \ldots \ldots \ldots \ldots \ldots \ldots \ldots \ldots \ldots \ldots$. decipiens
Labrum very densely hairy, these reddish $\ldots \ldots \ldots \ldots \ldots \ldots \ldots$

Mandibles about one and one-half times as long as basal width; ampullar tubercles very

large; southwestern

Pronotum dull, velvety pubescent, rugulose; feeds in living trees................. morrisii 
ACANTHODERES DECIPIENS Halleman

\author{
[Pl. XIIl, fig. 8; Pl. XXIII, fig. 4; Pl. XXIV, fig. 13; Pl. XVI, fig. 5]
}

Form short, rather robust, eylindric; integument firm, white, shining, sparsely clothed with dirty brownish hairs.

Head depressed, sides slightly constrieted before middle; epistoma straight; labrum about one and one-half times as long as wide, anterior half sparsely hairy; mandible black, shining, from side about twice as long as condylar width, cutting edge very obliquely emarginate; antennal ring open; one pair of rather indistinct ocelli. Fentral mouth-parts thick, rather hairy; mentum not defined at base, sunken; maxillary palpal joints subequal, last equal to last labial; ligula large; anterior edge of hypostoma curved, distinet; gula not distinet.

Prothorax rectangular, thick, widest about middle; pronotum anteriorly smooth, chitinizerl, a dense row of hairs across front, posteriorly shining, rugulose; prosternum hairy; eusternum and sternellum rugulose, shining, former fainily distinct. Mesonotum shining, metanotum, mesosternum, and metasternum shining, tuberculate.

Abdomen eylindric, slightly narrowing posteriorly; ampullae bearing two rows of large, irregularly defined tubercles; epipleurum protuberant only on last segments; tubercle broally oval, bearing two or three setae and two large distinet, chitinous pits. Spiracles orbicular, peritreme slightly chitinized. No caudal spine.

[Described from specimens Hopk. L. S. 10914a.]

Habits are described under the genus. It occurs throughout the eastern United States and Canada in Quercus, Betula, Castanea, Nyssa, Clmus, Hicoria, Prunus, Acer, Cornus, Ostrya and apple (Malus). Pupation take place in the sapwood from April to June.

\title{
ACANTHODERES QUADRIGIBBUS Say
}

A few specimens studied show the anterior half of the labrum very densely beset with ferruginous hairs; the pleurostoma below the ocellus and the anterior edge of the hypostoma are dull and finely granulate. The mandible is more slender.

Habits similar to those of decipiens. Occurs throughout the eastern United States and southern Canada in Quercus, Castanea, Betula, Fayus, Tilia, and Acer. Based on observations of W. S. Fiske and the author.

\section{ACANTHODERES sp.}

Distinguished from decipiens by the much more robust mandible, one and one-half times as long as basal width, and the much larger ampullar tubercles. Form more robust.

Pupa. Form as in adult; labrum bearing two transverse chitinous protulerances at base; front of head and pronotum bearing several chitinous setigerous points, as do also the mesonotum and metanotum, on the latter in a v-shaped figure; a short anterior and broader posterior row on each abdominal tergum. Anal segment squarely truncate, with several such points on its perimeter.

[Described from specimens Hopk. U. S. and 12283h.]

Habits similar. It has been reared from Populus and salix in Arizona. Collected by M. Chrisman.

\section{ACANTHODERES MORRISII Uhler}

Form very much more robust than in others of the genus; pubescence much coarser, stiff and very much sparser. Mandible shorter and more robust. Prothorax more chitinized on sides; posterior two-thirds of pronotum rugulose, dull, covered with sparse velvety pubescence. Ampullar tubercles very large. Spiracles very large and peritreme very strongly chitinized.

[Deseribed from specimens Hopk. U, s. $9786 \mathrm{~g}$.]

This species exhibits a character which is consichered as cleveloped through its environment, namely, the velured promotum. All other species are deaclwood feeders, while this one attacks living trees, and has the armature so common among forms with similar habits.

The habits of this species are exceptional to the genus. The larva was taken at Greenville, S.C., from living Nyssa. It was found making extensive galleries in the heartwood, very similar to those of Goes. Adults were reared in June. Observations by the author. 
DECTES SPINOSUS Say.

[Il. V, fig. 7; Pl. XII, fig. 4; Pl. XVI, fig. 3]

Form slencler, eylindrical, slightly curved; integument very finely granulate, shining, sparsely clotherl with fine whitish hairs.

lleal rather thick, expesed portion bearing very long hairs; sides narrowing very slightly postcrorly; labrum about twice as wide as long, wilest at base, shortly and coarsely ciliate; mandible rather slort, about one and one-half times as long as at base, apex acute, molar angle sharply toothed; antennal ring open behind; one pair of ocelli. Ventral mouth-parts fleshy; mentum distinct, narrow, transverse; last joint of maxillary palpi conical, longer than second, shortel than last habial, basal joints transverse; anterior margin of hypostoma fused with submentum, not distinet in middle; gula not distinct.

Protherax thick, rectangular; pronotum posteriorly very finely rugulose, anteriorly smooth, shining, laving a very sparse anterior border of hairs; eusternum not distinct, finely reticulated, very sparsely haired; sternellum smooth, shining. Mesonotum smooth, inetanotum, mesosternum, and metastermum faintly tuberculate.

Abdomen cylindrical; ampullae strongly protuberant, with a strong median impression, laterally tuberculate in two indistinct rows; epipleurum protuberant only on last three segments, tubercle narrowly oval, having several fine setae and no distinet pits. Spiracles orbicular, small, not strongly chitinous rimmed. No eaudal armature, ninth segment sparsely fringed with hairs.

Pupa. Form as in adult; remarkable for all absence of spines on head and thorax merely fine setae; abdominal terga armed with a few chitinous tipped papillae, growing more numerous on posterior segment, anal segment tipped with six larger dorsal and smaller lateral points.

[Described from specimens Hopk. U. S. $9784 c^{1}$.]

This larva attacks the living stems of Ambrosia, Eupatorium, and Xanthium and probably other composites. The egg is laid at a leaf base high on the stem and the larva mines down through the pith into the base of the roots, where pupation takes place. The life-cycle is completed in one year. The adult occurs through the eastern and central-western United States during July to August.

\section{LEPTOSTYLUS LeConte and LIOPUS Serville}

Form depressed; head depressed, sides slightly constricted for posterior two-thirds; labrum transverse, anterior margin semicircular; mandible about twice as wide as basal width; antennal ring open behind; mentum distinct, but little sunken into submentum; gula not distinet. Prothorax depressed, posterior area of protergum smooth and shining or velvety pubescent; ampullae irregularly tuberculate; epipleurum protuberant on last three segments, tubercle having two chitinous pores and from two to four setae.

Liopus can be separated from Leptostylus only by the fact that the posterior area of the pronotum is glabrous, shining; but as this characterization will not hold for Liopus variegatus, the two genera are treated together. The species are difficult of separation.

The species of Leptostylus and Liopus are nearly all bark feeders in the larva stage. The usual habit is to feed entirely in the bark proper or between the bark and wood. The burrows are loosely packed with fibrous frass. Pupation oceurs in the bark proper, between the bark and wood, or rarely (when the bark is thin) in the outer layers of the sapwood. One year is required to complete the life cycle though occasionally several generations or parts of generations may develop in the same season.

The following key will aid in distinguishing the known species.

\section{KEY TO THE KNOWN SPECIES OF LARVAE OF LEPTOSTYLUS} AND LIOPUS

Posterior area of pronotum velvety pubescent,

Velvety pubescence covering at least one-half of area.

Labrum not twice as long as wide.

Head widest in front.

Pubescence on pronotum and body hairs lighter.............. Leptostylus macula

Pubescence on pronotum and body hairs much darker.

Breeds in hardwoods....

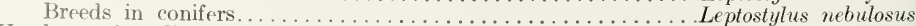

Leptostylus aculiferus

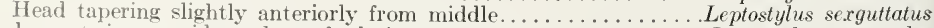

Labrum twice as wide as long, feeds in mangrove seeds.............. Leptostylus terraecolor

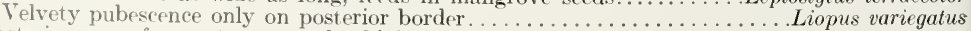
Posterior area of pronotum smooth, shining.

Anterior edge of labrum regularly rounded.

Anterior edge of labrum straight. 
LEPTOSTYLUS MAGULA Say.

[Pl. XVI, fig. 7; Pl. XXXI, fig. 3]

Form depressed, semi-robust; integument firm, shining, sparsely clothed with long, whitish, silky hairs.

Head depressed, sides slightly constricted about middle; epistoma slightly curved; labrum thin, about one and one-half times as wide as long, semicircular, rounded from basal extremities, sparsely and finely ciliate; mandible slender, little more than twice the length of basal width, cutting edge dull, obliquely truneate; antennal ring open behind; one pair of distinct ocelli. Ventral mouth-parts thin, pubescence fine and silky; palpi slender, last joint of maxillary palpi equal to second, shorter than first, or last labial; mentum distinet, scarcely sunken; hypostoma slightly curved; gula indistinet.

Prothorax rectangular, strongly depressed, widest at middle; protergum anteriorly shining, finely reticulated, posteriorly finely velvety pubescent; eusternum and sternellum shining, finely wrinkled, the latter velvety pubescent at extremities. Mesonotum velvety asperate on anterior half. Metanotum, mesosternum, and metasternum irregularly tuberculate.

Abdomen depressed; ampullae irregularly tuberculate, the tuberculate area constricted at middle and having a median longitudinal impression; epipleurum protuberant on last three segments, tubercle having a chitinous pore at each extremity and two or three setae. Spiracles orbicular, peritreme searcely chitinized.

Pupa. Form as in adult; slender, chitinous, setigerous points along front of head, a dense row across anterior margin of pronotum, and a few on lateral tubercles, several on mesonotum and metanotum and smaller ones, densely set, over abdominal terga (these not setigerous); last two segments bearing larger ones, and the caudal segment two incurved, slender spines.

[Deseribed from specimens Hopk. U. s. 11810 and $977 \mathrm{sp}$.]

This is one of the most common species of the genus. The larvae are found in a great variety of hardwoods, although chestnut is probably the most common host. In thick bark the larvae will often mine exclusively in it, or, if thinner, between the bark and wood. In small twigs and vines such as Celastrus the wood itself is mined, but then only when much decayed. Pupation normally takes place in the bark or between the bark and wood in an oval cell of fibrous frass. The species has been collected from Castanea, Cormus, Acer, Hicoria, Celastrus, and apple (Malus). Observations on the adult of this species show that it lives for several weeks to a month feeding on spores of bark fungi. The pustules of the chestnut bark disease (Endothia parasitica) are practically favoured. The adult is common throughout the eastern United states and Canada. It flies from May through July.

\section{LEPTOSTYLUS ACULIFERUS Say}

This species can only be separated from macula by the more robust form of the matured larvae and by the darker coloured, denser pubescence of the protergum; the labrum is willest about the middle instead of at base.

[Described from specimens Hopk. L. s. 11831a.]

Habits similar to those of macula. The writer has found it in living bark of apple trees. It normally prefers dead tissue. Adults have been reared from Liriodendron, Rhus, Cormus, Hicoria, CTmus, Juglans, and apple (Malus). The adult flies from May to October.

\section{LEPTOSTYLUS COLLARIS Haldeman}

Body hairs much longer than in macula, otherwise similar.

[Described from specimens Hopk. U. s. 11s17.]

Habits similar to those of macula. It has been found only in Castanca. Adults collected from May to June.

\section{LEPTOSTYLUS NEBULOSUS Horn}

Resembles macula, but larger, the pubescence on posterior area of pronotum much darker, and the body hairs much coarser.

[Described from specimens Hopk. U. S. 12593.]

The larvae feed entirely within the bark of dead Abies. Collected by J. M. Miller at Colestin, Oregon.

$57951-8 \frac{1}{2}$ 
I.EPTOSTYLUS PARVUS I,Conte

Kelults of this speceies have been reared from Celastrus and Worus, but only larval skins are arailable, and by these it can not be distinguished from the other species.

collected by A. B. Champlain, H. B. Kirk, and the author.

\section{IEPTOSTYLUS PINI Schaeffer}

A single larval skin can not be separated from the other species. Hopk. U.S. 122+16. It was reared from dearl branches of Pinus in the Catalina mountains of Arizona. Collected by M. C'hrisman.

\section{LEPTOSTYLUS TERRAECOLOR Horn}

Resembles macula, but the labrum is twice as wide as long; the spots of velvety pubescence at the extremities of the prosternellar area are not conspicuous; the body hairs are coarser.

[Described from specimens Hopk. U.S. $10081 w$.]

These larvae were collected by T. E. Snyder at Miami, Fla., in the seeds of mangrove. (Rhizophora mangle).

\section{LEPTOSTYLUS SEXGUTTATUS Say.}

Easily distinguished by the coarse, reddish hairs on the body and the head tapering anteriorly and posteriorly from a point a little before the middle; last joint of maxillary palpi longer than second, equal to last labial; pubescence on protergum very dark reddish brown.

[Described from specimens Hopk. U. S. $10080 \mathrm{~g}$ and $12295 \mathrm{a}$.]

The larva feeds between the bark and wood, pupating in the outer layer of sapwood. It is often associated with Acanthocinus and Monochamus. Adults have been reared from Picea and Pinus throughout the eastern United States. It flies in April and May.

\section{LEPTOSTYLUS BIUSTUS LeConte}

Several specimens in the forest insect collection of the U.S. Bureau of Entomology are in too poor shape to describe. Hopk. U. S. 7540.

The larvae feed under the bark of Morus, Rhus, Mimosa, Liquidambar, and Celtis. It has been collected in May and June from Virginia southward. Observations of W. F. Fiske and R. W. Van Horn.

\section{LEPTOSTYLUS ALBIDUS LeConte}

A single specimen reared from Populus in Arizona. The larva feeds in the bark. Collected by M. Chrisman. Only the larval skin is available Hopk. I. S. 10339 .

\section{LIOPUS VARIEGATUS Haldeman}

\section{[Pl. XXIV, fig. 6]}

Form more robust; integument finely alutaceous, shining. Mandible slender, twice as long as basal width; pronotum anteriorly shining, bearing hairs only across anterior border and lateral anterior angles, posteriorly faintly reticulated except for a very narrow transverse band of velvety pubescence, extending farther forward along median line; ampullae irregularly tubercula e pleural tubercles normally bearing three setae.

[Described from specimens Hopk. U. S. $9784 a^{1}$.]

This species is an intermediate form between Leptostylus and Liopus, the posterior velvety pubescence of the pronotum and the absence of hairs over the entire anterior area suggesting a closer affinity with Leptostylus.

The larval habits of this species are similar to those of Leptostylus macula It has been reared from Castanea, Juglans, Morus, Ulmus, Robinia, and Celas trus. Range, throughout the eastern United States and Canada. 


\section{LIOPUS ALPHA Say}

Form slender, subdepressed; integument firm, often finely granulate, shining, sparsely clothed with very fine whitish hairs.

Head slender; twice as long as anterior width, depressed, sides slightly constricted about middle; labrum transverse, about one and one-half times as wide as long, gra-lually rounded from just before posterior extremities, anterior half finely hairy; mandible rather robust, from side about one and one-half times as long as basal width, base clull granulate, cutting edge obliquely emarginate; antennal ring open behind; one pair of prominent ocelli. Ventral mouth-parts thin, mentum transverse, last joint of maxillary palpi one and one-lialf times as long as second, first and second subequal, shorter than last labial; ligula slender; anterior erlge of hypostoma slightly curved; gula indistinct.

Prothorax trapezoidal, slightly depressed, widest behind; pronotum anteriorly shining, regularly and sparsely haired, posteriorly shining, irregularly reticulated and striate; prosternum hairy, eusternum and sternellum shining, roughened; mesonotum and metanotum finely alutaceous to granulate, the latter faintly tuberculate, mesosternum and metasternum alutaceous to faintly tuberculate.

Abdomen. Dorsal ampullae irregularly tuberculate in two indistinct rows, broken in middle; epipleurum protuberant on last three segments, tubercle oval, and bisetose, a faint chitinous pit at each end. Spiracles orbicular, about size of ocellus, not chitinous rimmed.

Pupa. Form as adult, in life pinkish red in colour; body covered with slender setigerous points as follows: two at each angle of base of labrum, and fourteen on front of head; five across anterior pronotum, middle ones small, two on lateral protuberance; mesonotum and metanotum glabrous; fine points on abdominal terga, last segment bearing four large ones.

[Described from specimens Hopk. U. S. 12298.]

A number of colour forms of this species have been reared, notably brown from Rhus, gray from Hicoria, and black from Castanea and Quercus. The larvae show some slight differences, but until more material is available for at thorough study no attempt will be made to separate them. These forms all breed in small dead twigs, pupating in the wood. They have been reared also from Acer, Celastrus, Celtis, Morus, Diospyros, Robinia, Juglans, and Ampelopsis.

\section{LIOPUS PUNGTATUS LeConte}

Similar to L. alpha; the mandibles are shorter and entirely finely granulate; labrum twice as wide as long, anterior edge nearly straight for a short distance; posterior area of pronotum marked with large reticulations though lines are fine; eusternum also so marked; tubercles on ampullae confluent.

[Described from specimens Hopk. U. S. 9789e.]

This larva is commonly found in persimmon twigs girdled by Onrideres. It feeds under the bark and in the outer sapwood, extending the burrow into the pith, where it pupates. It has been reared also from Virginia creeper (Ampelopsis), Cornus, and plum trees (Prunus).

Range, from Virginia southward.

\section{HYPERPLATYS ASPERUS SaY}

Form subcylindrical, slender; integument very finely granulate, shining, sparsely clothed with fine whitish hairs.

Head depressed, exposed portion finely granulate, sides slightly tapering; anterior margin of labrum roundly curved from behind middle, one and one-lialf times wider than long; mandible slender, twice as long as wide, basal half fincly gramulate; antenual eavity open; one pair of ocelli. Maxillary palpi slender, last joint slightly shorter than two basal joints, shorter than last labial; mentum distinct, transverse, not sunken; anterior edge of liypostoma roundly curved; gula not protuberant.

Pronotum smooth, shining except for very narrow posterior border of dull fine granulations, sometimes extending over one-third of the area.

Ampullae tuberculate, the tubercles arranged in two irregular rows; pleural tubercle, with two very distinet chitinous pits and several setae. Spiracles orbicular, about the size of the ocellus, rather strongly rimmed. No caulal spine.

Pupa. Form as in adult; about 20 small setigerous points on front of head (inchuling base of antennae), a row of 10 on anterior margin of pronotum, and a group on anterior lat eral angles; mesonotum and metanotum glabrous; an irregular median group on abilominal terga (these very small), larger ones on penultimate segment and still larger ones (about s) on last segment.

[Described from specimens Hopk. [. S. $977 \mathrm{sm}$.] 
1 latge series of this material has been reared in which two forms of adults are found, cach being constant in the same food plant in the same locality. An equally large series of larvae, however, show no constant differences. The larvac mine under moist bark, making a short pupal ecll in the sapwood plugged with a wad of fibrous frass. The adult emerges through the same hole through which the larvac entered the wood. One complete and a partial second generation oceur each year under favourable conditions. Larvae and adults have been collected throughout the eastern and rentral western United States and Canacla from lihus, Castanea, Cornus, Tilia, Juglans, Celtis, Alnus, Celastrus, and Prumus. Adults fly from April to June.

\section{LEPTURGES SYMMETRICUS Haldeman}

[PI. XVI, fig. 1; Pl. VII, fig. 5]

Form sub-depressed, slender; integument firm, shining, very finely wrinkled, sparsely clothed witl fine whitish-yellow pubescence.

Head depressed, exposed parts finely granulate, sides tapering gradually posteriorly; labrum very broadly oval, little wider than long; mandlible slender, finely granulate at basc, about twice as wide as basal width, eutting edge dull, obliquely rounded; antennal cavity open behind, a slight projection above; one pair of large ocelli. Ventral mouth-parts thin; mentum distinet, not sunken, twice as wide as long, it and stipes finely granulate; last joint of maxillary palpi longer than seeond, about equal to or slightly shorter than basal and last labial; anterior edge of hypostoma slightly eurved; gula not distinct.

Prothorax trapezoidal, widest behind; pronotum entirely shining, finely reticulated to alutaceous, a few scattered hairs anteriorly: sternum shining, rugulose, wrinkled, hairy, eusternum and sternellum glabrous. Mesonotum shining, finely wrinkled; metanotum, mesosternum, and metasternum tubereulate.

Abdomen shining, subcylindric; ampullae bearing two transverse rows of tubereles; cpipleurum protuberant on last three segments; pleural tubereles large, oval, having two chitinous pits and from 3 to 4 setae. Spiracles orbicular, smaller than ocellus, peritreme slightly chitinized. The last abdominal tergum bears a long, very slender, acute, curved, chitinous spine.

[Deseribed from specimens Hopk. U. S. 9778v.]

Working under moist lecayed bark the larvae either enter the sapwood or bark to pupate. This species breeds most commonly in Juglans but also in Hicoria, Celtis, Morus, and Castanea. The adults are found throughout the Eastern United States and Canada during June and July.

\section{LEPTURGES SIGNATUS LeConte}

A single specimen of this larva, Hopk. U.S. $9789 \mathrm{~s}$, shows no decided differences from symmetricus. It was collected at Cedar Mountain, N.C., under the bark of Acer by the author.

\section{LEPTURGES QUERGI Fitch}

Form subdepressed, slender; integument firm, smooth, shining, sparsely clothed with fine, whitish hairs.

Head depressed, sides gradually tapering posteriorly, exposed parts finely granulate; mandible slender, finely granulate at base; antennal eavity closed; one pair of very large ocelli. Ventral mouth-parts thin; mentum distinct, not sunken; maxillary palpi two-jointed, last joint longer than basal; gula not distinet.

Prothorax trapesoidal, widest behind; pronotum anteriorly finely granulate and hairy, posteriorly faintly and sparsely striate; eusternum shining, glabrous. Mesonotum shining. IIetanotum tubereulate.

Abdomen shining; dorsal ampullae bearing two rows of regular tubercles; epiplcurum protuberant on last three segments; pleural tubercle large, subrectangular, no chitinous pits. Spiraeles very small, orbieular, peritreme chitinized; no caudal spine.

Pupa. Form as in adult; a group of 18 to $20 \mathrm{long}$ setae on front of head and at base of antennae; a few scattered finer ones on pronotum; mesonotum and metanotum glabrous; first few abdominal terga with a very few very small chitinous points, becoming more dense on posterior ones, last scgment armed with 4 or 5 longer points.

The larva feeds under the bark and often through the sapwood, constructing the pupal cell in the wood or bark of Juglans, Castanea,Oxydendron,Celastrus, and apple (Malus). Adults are collected throughout the eastern United States from IIay to June. Observations by A. D. Hopkins, W. F. Fiske, A. B. Champlain, and the author. 


\section{LEPTURGES SPERMOPHAGUS Fisher}

Distinguished from querci by the more robust form and fine velvety pubescence on the posterior area of the pronotum. The ampullar tubercles are not so regular and are more deeply divided by a longitudinal depression.

[Described from specimens in the United States National Museum collected by D. L. Crawford at Tampico, Mexico.]

The larvae feed on the seeds of cowpeas (I igna).

These species, L. querci and L. spermophagus, are strikingly different from symmetricus-like forms. The closed antennal ring, two-jointed maxillary palpi, absence of chitinous pits on pleural tubercle, and absence of caudal spine are certainly of generic value, and would be sufficient criteria for separating them into a new genus. They are very closely allied to Pogonocherus and Ecryus.

\section{ACANTHOGINUS Stephens}

Form depressed; head strongly depressed, sides suddenly constricted before middle; mandible slender from side, length about three times basal width; antennal ring slightly notehed or angulate but not distinctly bisected by frontal suture; mentum distinet; gula not protuberant. Posterior area of pronotum finely, velvety pubescent; ampullae not tuberculate, velvety pubescent, dull; pleural tubercle broadly oval, bearing two chitinous pits and numerous setae. Spiracles orbicular.

The species of this group, like Monochamus, are all pine feeders and are invariably associated in the same trees with them. Although often eonfused with Monochamus, Acanthocinus is strictly a genus of bark-feeding species. The whole larval period is passed in the bark proper, or in some species beneath the bark, the larvae never penetrating into the sapwood, except occasionally in one species, A. obliquus, to pupate. The eggs are laid in a deep pit gnawed by the female, or in scolytid holes, the young larvae soon penetrating into the deeper layers of bark. Pupation takes place near the surface in the dryer tissues. All species normally mature in one season. Many larvae are destroyed by predatory enemies, clerids and trogositids. They are important in destroying Dendroctonus spp. Attacking the trees shortly after the barkbeetles, their extensive mines destroy the inner bark and food supply of these beetles. Large numbers of the broods are thus destroyed.

\section{KEY TO DESCRIBED SPECIES OF ACANTHOCINLA}

Last joint of maxillary palpi much shorter than second; first joint of labial palpi twice as long as last; mentum with four or more setae on each side.

Anterior margin of labrum regularly rounded. (IVestern)

Anterior margin of labrum straight or emarginate. (Lastern)

1. spectabilis 1. nodosus

Last joint of maxillary palpi about as long as second; first joint of labial palpi not twice as long as last; mentum never bearing more than two setae on each side.

Eusternum and sternellum of prothorax smooth, shining. (Easteris)

Eusternum and stemellum of prothorax roughened. (IVestern)

1. obsoletus

1. obliquus

\section{AGANTHOGINUS NODOSUS labricius}

Form elongate, strongly depressed, slighting tapering posteriorly; integument firm, rather densely beset with fine yellowish-white hairs.

Ilead very strongly depressed, sides sudilenly constrictel before midile; anterior nargin very darkly chitinized; epistoma abruptly declivous, faintly carinate; labrum transver:se, about twice as long as wide, anterior margin very finely and densely ciliate; mandible very slender, elongate from side, three times the condylar breadth, apex squarely emarginate; antennal ring angulate behind; ocelli not conspicuous. Ventral mouth-parts elongate; mentum twice as wide as long, distinct; maxillary palpi acutely conical, last joint little more than one-half length of second, shorter than last labial, first labial twice as long as last; anterior edge of hypostoma straight, abrupt; gula not distinct.

Prothorax strongly depressed, about twice as wide as long; pronotum anteriorly shiniug, bearing a dense row of very short and fine hairs, posterior two-tlirds velvety pulbescent, except for numerous small glabrous spots; presternum deusely hairy anteriorly; eusternum anel sternellum shining, strongly reticulated; mesonotum shining exeept for anterior margin, reticulated; metanotum, mesosternum and metasternum bearing two transverse rows of velvety pubescence. 
Ibetomen: Impullas broat, flat, vory fincly asperate, pubeserent; epipleurum strongly protulberant only on list three segments, tuberche oval, a chitinous pit at each extremity and

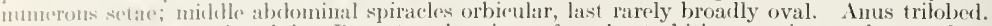

l'upe. lorm as in achult. Pronotum bearing a few short chitinous points and many long stender listirs; mesonotum and metanotum glabrous; each abdominal tergum bearing a transverse row of chitinous reflexed points, more numerous at each side of median line; a group on ovipesitor near base, and extremity of ovipositor bearing a circle of small incurved points.

1) (s)eribed from specimens Hopk. U. S. 3475.]

The larval habits have been described under the genus. The species occurs from Virginia southward through Texas. The larvae are very abundant, but the adult so closely resembles the bark on which it occurs that it is not commonly collected. Pupation takes place from May until July. Based on olservations of A. D. Hopkins, J. L. Webb, H. E. Burke, and the author.

\section{AGANTHOGINUS SPECTABILIS LeConte}

[Pl. XIII, fig, 4]

The lrairs covering the body are usually whitish and much finer (silky) than in nodosus (this is best observed on the anal lobes). The fine asperities of the ampullae are not individually distinguishable with a "Zeiss-4 eyepiece," $\mathrm{A}^{\circ}$ objective; while in nodosus thay can be. The anterior margin of the labrum is uniformly rounded, while in nodosus it is straight or slightly ('marginate for a short distance.

Pupa. Similar to nodosus, but the chitinous points on the abdominal segments do not extend across and are not so numerous.

[Described from speeimens Hopk. U. S. 10077c.]

This species occurs through the western United states and Canada, but is more abundant in the southwest. The adult flies from April to August.

\section{ACANTHOGINUS OBSOLETUS Olivier}

In form and general structure similar to nodosus, but much smaller. Last joint of maxillary palpi equal in length to second (not shorter); first joint of labial palpi not twice as long as last. Proeusternum and sternellum smooth, shining; anterior border of hairs across protergum relatively longer.

Pupa. Distinguished from spectabilis by the smaller size and absence of chitinous points on the pronotum.

[Described from speeimens Hopk, U, s, 6332a.]

This species has a wider range than the other species of the genus, extending from Texas northward through the New England States and west into Michigan. Pupation oceurs from April to July, according to latitude.

\section{ACANTHOGINUS OBLIQUUS LeConte}

Structually similar to obsoletus. The matured larva is much smaller, and both the velvety asperities and the pubescence are coarser and darker. Proeusternum and sternellum of prothorax slightly roughened.

[Described from specimens Hopk. U. S. 11917a.]

This species occurs through the Rocky Mountains and Pacific Coast regions in Pinus. It often works in the inner bark of pines, pupating in the outer layers of sapwood. The adults fly from April to August. A. B. Champlain has recorded it from Picea parryana.

\section{GRAPHISURUS Kỉby}

In general similar to Acanthocinus. Readily distinguished by the flattened chitinous process on the last abdominal tergum. Mandibles shorter, rarely more than twice the condylar width. Head relatively narrower.

The species of Craphisurus are all hardwood feeders. The larvae feed between the bark and wood, pupating in the sapwood, in the bark, or between the bark and wood. 


\title{
GRAPHISURUS FASGIATUS DeGeer
}

\author{
[Pl. XVI., fig. 6; Pl. VHI, figs, 3 and 4; Pl. XXXII, fig. 3.]
}

Form depressed, elongate; integument firm, very finely rugulose, rather densely clothed with yellowish white hairs.

sides of head narrowed before middle; labrum thin, anterior edge broadly rounded, densely hairy; antennal ring angulate; ocelli not visible; last joint of maxillary palpi equal to second, longer than last labial.

Prothorax rectangular, depressed; pronotum anteriorly shining, bearing a transverse band of dense hairs, posteriorly velvety pubescent; eusternum velvety pubeseent, as also sternelhum except for a median glabrous area. Mesonotum, metanotum, mesosternum and metasternum dull velvety pubeseent.

Abdomen. Ampullae velvety pubeseent; pleural tubercle broadly oval, bearing two (hitinous pits (ventral often obscure) and numerous fine hairs. Posterior dorsal margin of ninth abdominal segment bearing a small transverse, flattened, chitinous process. Spiracles orbicular.

Pupa. Form as in adult; groups of chitinous points arranged as follows: A group at each basal angle of pronotum; a curved band across metatergum; an irregular, transverse posterior band and an anterior median group on each ablominal tergum, and a group on basal half of ovipositor.

[Described from specimens Hopk. U. s.. 11s06a.]

The larvae feed between the bark and wood of a great variety of hardwoods. They prefer to attack trees the season after their death, provided a certain amount of moisture is present. They are often found in great numbers in a single tree. It has been collected from Castanea, Fagus, Quercus, Micoria, Liquidambar, Acer, Juglans, Tilia, and Betula throughout the eastern United States and Canada. Pupation takes place from March to July, usually in the earlier months.

\section{GRAPHISURUS HEBES Casey}

Closely resembling $G$. fasciatus. The specimens examined have the anterior edges of the epistoma and hypostoma produced in a faint carina; proeusternum slining; ampullae wrinkled or semi-tuberculate.

[Described from specimens Hopk. U. S. 9771.]

The adult of this species is of a much lighter colour. It has been taken only from IIicoria and pupates in the bark proper. Range, Northeastern United States and Canada.

\section{GRAPHISURUS TRIANGULIFER Haldeman}

Resembles G. fasciatus but the caudal process is much larger and the eusternum and the central area of the sternellum are shining and wrinkled.

[Deseribed from a single poor speeinen in the I. S. National Museum.]

Collected under the bark of Celtis, columbus, Texas. Probably this is the same specimen which Packard (23) describer. Riley (27) gives a brief note on the food habits of this species.

\section{NYSSODRYS IIALDEMANI LeConte}

\section{[Pl. XII, fig. 7]}

Head depressed, widest a little distance behind the epistoma (i.e., slightly tapering both anteriorly and posteriorly); mandible slender, several times the length of the condylar width; labrum twice as wide as long, sparsely haired; antennal ring elosed; ocelli not distinet; gula indistinet, very shallow.

Posterior area of pronotum velvety, having a border of hairs across anterior area; eusternum and median area of sternellum glibrous, wrinkled; metanotum, mesosternum, and motasternum faintly tuberculate, bordered with velvety pubeseence.

Ampullae irregularly tuberculate; spiracles orbieular. Ninth tergum bearing a very minute flattened median process on posterior borkler.

Pupa. Resembles Graphisurus except that the pronotum, mesonotum, metanotum, head at base of antennae and the femoral-tibial articulation are beset with a group of long stiff setae; abdominal terga beset with fleshy papillae, each bearing a silky hair.

[Deseribed from specimens in the [. A. Bureau of Lintomology collection No. 3342.]

The larvae were taken from Celtis in Missouri. 
Vory similar to Graphisurus except that the caudal spine is extremely minute, scarcely distinguishable with a high-power lens. The ampullae are distincty tubereulate, consisting of several irregular rows, the dorsal bordered with velvety pubesecnee.

\section{GRAPHISURUS sp.}

I larva is present in the collection very similar to Graphisurus fasciatus, hut it may be distinguished by the absence of a caudal spine, the somewhat coarser pubescence on pronotum and ampullae and by the fact that the last joint of the maxillary palpi is shorter than the penultimate and still shorter than the last labial. The texture is finely granulate.

The antennal ring is distinctly open behind and suggests that this is a normal feature of the group.

[Deseribed from specimens Hopk. U.S. 10075q.]

Collected from Quercus in Arizona.

\section{GERATOGRAPHUS sp.}

From a larval skin (the only available material) this species plainly is related to Graphisurus, etc. The antennal ring is open behind and the last joint of the maxillary palpus is longer than either of the basal joints; the basal joints are about as wide as long.

[Described from specimens Hopk. U. S. 9901z.]

Collected from Pinus in Colorado.

The species of Pogonocherus, Ecyrus, and Cyrtinus all show many characters in common and are here considered related. They have the robust cylindrical from; closed antennal ring; last joint of maxillary palpus exceptionally long ; glabrous, striate pronotum and eusternum; bilobed ampullae indistinctly tuberculate; and usually a caudal process or spine.

\section{EGYRUS DASYGERUS Say.}

\section{[Pl. V, fig. 9; Pl. XII, fig. 1; Pl. XXIV, fig. 4; Pl. XXXI, fig. 2]}

Form subcylindrical, tapering posteriorly, then laterally compressed; integument very smooth, shining, sparsely elothed with fine whitish hairs.

Head rather thick, sides parallel; labrum thin, broadly oval, widest at middle, nearly glabrous; mandible short, shining except for a band of coarse granulation on outer face, very acute, dorsal angle abruptly toothed; antennal cavities closed; one pair of small ocelli. Ventral mouth-parts fleshy; mentum distinet, narrow, transverse, sunken; maxillary palpi slender, last joint much longer than second, longer than last labial; hypostoma somewhat bulging transversely; gula indistinet.

Prothorax thick, trapezoidal, widest behind; pronotum posteriorly shining, very finely striate, anteriorly regularly, densely and finely haired; sternum hairy except for embossed diamond-shapel, smooth, shining eusternum and shining sternellum. Metanotum, mesosternum, and metasternum finely wrinkled, shining.

Abdomen rather compressed; ampullae with a broad median longitudinal furrow, subtuberculate at lateral extremities; epipleurum protuberant on last three segments, tubercle very small, abruptly projecting, oval, no chitinous pits and only one slender seta. Ninth tergum armed with a short, small, triangular process.

[Described from specimens Hopk. U. S. 12254.]

This larva is a true wood-feeder, mining small but extensive burrows through the dry sapwood and heartwood of branches and larger limbs. The mines are tightly packed with fine, rather granular frass. Dry seasoned limbs on the trees are preferred. It has been collected throughout the eastern and southwestern United States from Castanea, Quercus, Robinia, Prosopis, Celtis, Acer, Paulownia, and Ampelopsis. The adult flies from April to July. 
POGONOCHERUS Latreille

Small, sub-cylindrical species; head thick, sides slightly constricted behind middle; mandible short, granulate on outer face; antennal ring closed; mentum distinct, sunken, narrow, maxillary palpi two-jointed (in $P$. negundo, three-jointed); gula not evident; posterior area of pronotum shining; ampullae with a broad longitudinal median furrow, feebly tuberculate; pleural tubercle abruptly protuberant, no chitinous pits and one seta; ninth tergum bearing a chitinous process or plate.

The species of Pogonocherus are very similar in habits to those of Eupogonius. They feed under the bark of recently dead hardwoods and conifers (chiefly the latter), making a small Monochamus-like pupal cell in the sapwood, plugged at both ends with fibrous chips. The larval period extends through one season. Rather moist conditions are required.

\section{POGONOCHERUS NEGUNDO Skinner}

Distinguished from Ecyrus dasycerus by the coarser body hair and the absence of all tuberculation on the metanotum and ampullae, which are smooth and shining; last joint of maxillary palpi twice as long as second and mandible entirely granulate on outer face.

[Deseribed from specimens Hopk. U. S. 10386a.]

These larvae were collected by M. Chrisman mining in dead and dying branches of boxelder $(A c e r)$ in the Catalina mountains of Arizona. The mines were rather extensive, meandering through the heartwood. Pupation takes place in a cell in the sapwood. The work is very suggestive of that of Ecyrus dasycerus.

The fact that this species of Pogonocherus so closely resembles Ecyrus dasycerus and like it, has the three-jointed maxillary palpi, would suggest either that it should be included in that genus or that the two genera should be grouped.

\section{POGONOCHERUS MIXTUS Haldeman}

[Pl. XVII, fig. 19; Pl. VII, figs. 1 and 2]

Form cylindrical; integument very finely granulate, shining, sparsely clothed with fine, whitish-yellow hairs.

Head rather thick, sides slightly constricted behind middle; clypeus finely granulate; labrum roundly rectangular, about one and one-half times as wille as long, sparsely ciliate in front; mandible not twice as long as basal width, finely granulate on outer face, cutting-edge obliquely truncate; antennal ring closed; one pair of distinet ocelli. Ventral mouth-parts rather thick; mentum little wider than long, distinct, sunken; maxillary palpi two-jointed, last joint longer than last labial; hypostoma slightly bulging transversely.

Prothorax trapezoidal, thick, widest behind; pronotum posteriorly finely reticulated, shining, anteriorly very finely rugulose, regularly and finely haired; sternum hairy, shining; sternellum rather broad, smooth, shining; mesonotum and metanotum finely rugulose, reticulated, shining; mesosternum and metasternum smooth.

Abdomen: Ampullae with a deep, broad, longitudinal median impression, wrinkled but not tuberculate; epipleurum protuberant on last segments, tuberele small, oval, abruptly projecting, no chitinous pits, one seta; ninth abdominal tergum bearing a large, oval, longitudinally carinate plate considerably smaller than labrum. Spiracles very small, orbicular, slightly chitinous rimmed.

Pupa. Form as in adult; remarkable for not having a chitinous process or spine or body except an acute conical one on last abdominal tergum. Coarse hairs in two groups on mesonotum and metanotum.

[Deseribed from specimens Hopk. U. S. 11853b.]

This species feeds in various branches of Pinus and Picea throughout the eastern and central western United States and Canada. The adult flies throughout June and July.

\section{POGONOCHERUS PENCILLATUS LeConte}

Similar to mixtus but the ampullae are more decidedly tuberculate and the caudal spine is reduced to a mere point or one or two carinae.

[Described from specimens Hopk. T. S. 3771.] Fiske.

These larvae were collected in Picea at Grand Island, Michigan, by II. F. 
POGONOCHERUS sp.

This larva resembles mixtus but the earinae on the eaudal plate are very pronounced, five or six in number, and the ampullae are more tubereulate than wrinkled.

(1) sercibed from syecimens Hopk. ['. S. 10061b.]

The larvate feed uncler the bark of dead branches of Pinus flexilis, working as mixtus. Collected by A. B. Champlain at Cascade, Colo.

\section{POGONOGHERUS SALICOLA Casey}

[Pl. VII, fig. 8]

Differs from mixlus in the finer whitish hairs on body and in the fact than the caudal plate is about the same size as labrum and the carinae much coarser and from six to ten in number; spiracles hardly visible, peritreme not chitinous rimmed.

P'upa. Hairs very fine whitish, caudal spine not chitinous.

These specimens were kindly given the author by C. A. Frost. They were collected in dying Salix at Framingham, Mass. This species has also been collected by A. B. Champlain in Salix at Colorado Springs, Colo. (Hopk. U.S. $10072 a$.

\section{POGONOCHERUS CALIFORNICUS Schaeffer}

Form more robust; posterior area of pronotum finely and irregularly longitudinally striate; custernum glabrous, very smooth; caudal process a blunt triangular point.

[Described from specimens Hopk. U. S. 2771.]

This larva has been reared from Pinus and Picea in Ventura Co., California. Notes by A. D. Hopkins.

\section{CYRTINUS LeConte}

Leconte and Horn (20) have placed this genus in a distinct tribe near Psenocerus. Lacordaire (19) has retained this tribe, but places it following the Acanthocinides. Its larval affinities are evidently close to Psenocerus, and since the Apodasyides of Lacordaire, including Psenocerus and Eupogonius, are related to the Pogonocherides, it is placed near them.

\section{GYRTINUS PYGMAEUS Haldeman}

\section{[Pl. XII, fig. 9; Pl. XXIV, fig. 1; Pl. XLII]}

Form cylindrical, cuneate; integument thin, shining, very sparsely beset with fine, short whitish hairs.

Head depressed, twice as long as wide, sides suddenly constricted near base; epistoma thin, straight; labrum roundly rectangular, about one and one-half times as wide as long, widest at base; manclible slender from side, about twice as long as basal width, shining, cutting edge deeply emarginate, dorsal angle bluntly toothed; antennal ring elosed; no ocelli. Ventral mouth-parts not chitinized; maxillary palpi two-jointed, last joint twice as long as basal, longer than last labial; ligula wide; gula indistinct.

Prothorax roundly quadrate; pronotum anteriorly smooth, shining, posteriorly not well defined at sides, with a median, smooth, shining, protuberant area, bounded by two rows of pinnately oblique striae on each side, these arising from two longitudinal impression.

Ampullae bearing two transverse rows of very small tubereles. Spiracles orbicular. No caudal spine.

[Described from specimens Hopk. U. s. 10082k and 11845a.]

This larva lives under the dry dead bark of a variety of hardwood twigs. It has been collected from Quercus, Hicoria, Cornus, Liriodendron, Robinia, and Acer. The larvae make a very short meandering gallery before pupating in a convex oval cell scarred into the wood. Several generations of adults appear during the summer, the first emerging about the time the oak leaves are halfformed. Observations by A. B. Champlain and the author. 


\section{HOPLOSIA Mulsant}

The striking resemblance of this larva to Acanthoderes, both in form and general structure, is at once apparent, and the author believed at first that it was related to this genus. The large pores on the pleural tuberele also confirmed this opinion, but the ampullae resemble those of such forms as Pogonocherus, while the open antennal cavity suggests Eupogonius; so also to the pupal characters. It may be regarded as representing a form intermechate between these genera. The peculiar carina on the anterior margin of the front is found nowhere else in the subfamily except in Oncideres.

\section{HOPLOSIA NUBILA LeConte}

Form robust, cylindrical; integument tough, shining, rather thickly beset with coarse reddish hairs.

Head depressed, sides very slightly constricted before middle; epistoma abrupt, bearing a transverse row of 18 to 20 coarse carina; labrum thin, roundly rectangular, anterior half beset with short stiff hairs; mandible about twice as long as basal width, cutting-edge weakly emarginate; antennal ring closed; ocelli distinct. Ventral mouth-parts thick; mentum distinct, sunken, about twice as wide as long; last joint of maxillary palpi conical, about equal to penultimate, shorter than last labial; gula indistinct.

Prothorax rectangular; pronotum rectangular, posteriorly rugulose; eusternum distinct, triangular, rugulose and coarsely haired; metanotum and metasternum tuberculate.

Abdomen. Ampullae rather flat, broad, with a shallow impression in middle, dividing two groups of very large, irregularly disposed tubercles; epipleurum protuberant only on last three segments, tubercles very large, broadly oval, having two exceptionally large chitinous pores and two setae, one much longer than the other. Spiracles orbicular, large, peritreme strongly chitinous.

Pupa. Form like that of adult; head bearing a few long setae; setigerous tubercles on pronotum in a dense row on anterior margin, a few on lateral margin, two groups on clise, and one on median posterior margin; mesonotum and metanotum each with a seattered group; abdominal terga armed with a transverse row of short, acute, reeurved, subulate, chitinous points; last tergum bearing an acuminate, erect spine, and a smaller one on lateral margin.

[Described from specimens Hopk. U.S. 11869f.]

The larva feeds between the bark and wood of decaying linden (Titia) logs. The matured larva enters the moist sapwood to make a short, hroad pupal cell plugged at the entrance with a wad of coarse fibrous frass. It is often associated with Acanthoderes, and the work can scarcely be distinguished from species of that genus. The adult oceurs throughout the northeastern United States and Canada. Larvae have been collected by H. S. Barber, J. N. Knull, and the author.

Lacordaire (1869) has included in this tribe our genera Psenocerus and Eupogonius. The larvae resemble each other in form, in the shining, weakly striate pronotum, and in the two rows of tubercles on the ampullac. For the present this position is held tenable. Psenocerus, however, very strongly suggests Oncideres, and might equally well be placed as a related genus, while Eupogonius shows affinities to the Pogonocherides.

\section{EUPOGONIUS LCConte}

Form cylindrical, elongate; head depresserl, widest just behind anterior margin, sides strongly constricted behind middle; antennal eavity open; one pair of ocelli; mentum distinct, sunken; pronotum posteriorly shining, strongly longitudinally striate. Ampullae beariug two rows of regular tubercles; epipleurum protuberant on last abdominal segments, tubereles t-setose, no chitinous pits.

The species of Eupogonius feed in the dearl branches and twigs of both hardwoods and conifers. The young larvae mine the first season under the bark, the following season entering the wood to form a U-shaped pupal cell lying in the same plane as the grain of the wood; both ends are plugged with fibrous chips. The adult emerges from the opposite end through which it entered. The work resembles that of a minute IJonochamus. ()bservations on all caged material show that the species often pass two seasons in the larva stage 


\title{
EUPOGONIUS TOMENTOSUS Hakleman
}

\author{
[I'l. V. fig. 3; P'l. XIII, fig. 6; Pl. XXIV, fig. 14; Pl. XVI, fig. 7]
}

Form exlindric, elongate; integument firm, smooth, shining, very sparsely clothed with yellowish brown hairs.

Ilecul depressed, widest just behind anterior margin, tapering anteriorly and strongly constricted about niddle; labrum widest at base, roundly rectangular, a very few short hairs on anterior margin; anterior margin of clypeus flatly granulate; antennal cavity open; one pair of distinct ocelli; mandible about one and one-half times as long as basal wilth, finely granulate, cutting edge deeply emarginate. Tentral mouth-parts rather thick; mentum distinet, one and one-half times as wide as long, finely granulate; stipes finely granulate; last joint of maxillary pilpi longer than second, about equal to basal, shorter than last labial; anterior edge of hypostoma strongly curved, fincly granulate; gula indistinet.

Prothorax rectangular, thick, widest behind; protergum anteriorly smooth, shining, laving a border of short, stiff hairs and a few just in front of posterior striate area; prosternum beset with stiff hairs, finely granulate except for shining eusternum and sternellum; mesonotum shining; metanotum, mesosternum, and metasternum tuberculate.

Abdomen cylindrical, ampullate having two well marked rows of regular tubereles, not divided in midlle; epipleurum protuberant on all segments, tuberele very large, oval, four setae, no ehitinous pits. spiracles orbicular, smaller than ocellus, chitinous rimmed.

Pupa. Form like that of adult; armed with stiff, short setae as follows: A central group on pronotum, two on each side of anterior margin, and two groups of about four on posterior margill; mesonotum and metanotum each with two converging rows; two transverse bands of three or four each on first six abdominal terga; last segment bearing a strong acute, recurved spine.

[Described from specimens Hopk. U. S. 12295b.]

The habits are as described under the genus. It occurs throughout the eastern United States and Canada in Pinus, Picea, and Cedrus deodar. Adults fly in July and August.

\section{EUPOGONIUS VESTITUS Say.}

Very similar to tomentosus, except that the band of hair on anterior protergum is not continuous across the segment and these hairs are finer.

Pupa. Similar to tomentosus, except that only the dise of pronotum has setae and these are arranged in more or less of a circular manner.

Habits similar to those of tomentosus. Reared from Morus, Cornus, Juglans, Cercis, Celastrus, Acer, Fraxinus, and Asimina.

\section{PSENOCERUS SUPERNOTATUS SAY.}

\section{[Pl. XIII, fig. 1; Pl. XXIV, fig. 8; Pl. XVI, fig. 4]}

Form cylindrical, elongate; integument firm, shining, or very finely wrinkled, beset with very short, fine, whitish hairs, denser and reddish-brown on prothorax and last abdominal segments.

Head rather thick, oval in cross section, suddenly constricted near base; mouth-frame, gena, and hypostoma rather heavily chitinized, yellowish brown; epistoma straight, thin; labrum roundly rectangular, twice as wide as long, widest at middle; mandible dull granulate, rather short, about one and one-half times as long as basal width, cutting-edge obliquely emarginate, angles rounded; antennal ring open behind; one pair of distinct ocelli. Ventral mouthparts rather full, last joint of maxillary palpi as long as two basal joints, equal to last labial, both chitinized; ligula large, distinct; mentum not distinet; hypostomal area sharply rectangular, transversely protuberant, quite heavily chitinized, finely granulate; gular suture a faint line.

Prothorax roundly rectangular, thick; pronotum defined by lateral sutures behind, anteriorly marked by broad, light ochraceous band, longitudinally carinate in middle, posteriorly protuberant, white, shining, bearing a few faint longitudinal striae; sternum anteriorly and laterally bearing two pairs of light ochraceous spots; eusternum distinct, shining, beset with a number of hairs; mesonotum smooth; metanotum, mesosternum and metasternum tuberculate.

Abdomen bearing prominent ampullae on seven segments, these armed with two rows of regular tubercles; epipleurum protuberant only on last three segments, tubercle narrowly oval, elongate, no chitinous pits; ninth segment fringed with long dense hairs, the tergum bearing a very short, cylindrical, truncate process; anus trilobed. spiracles orbicular, strongly chitinous rimmed, distinct.

Pupa. Form as in adult; pronotum bearing two anterior transverse rows of hairs; mesonotum and metanotum glabrous, shining; abdominal terga bearing two rows of setigerous papillae, last segment more densely hairy, ventral areas glabrous.

[Described from specimens Hopk. U. S. 978 $1 f .{ }^{1}$ ]

This larva feeds in dead decaying branches of Celastrus, Hicoria, Castanea, Liquidambar, Rhus, Lonicera, Euonymus, Cornus, and Ribes. It is most abund- 
ant in Celastrus. The larvae extend their mines under the bark for a short time, then go into the wood, and pupate in early spring in a cylindrical cell in the pith. Range, throughout the eastern and central western United States and Canada.

\section{SAPERDA Fabricius}

Elongate, cylindrieal species; head depressed, sides nearly parallel, base broadly rounded; antennal annulae closed; mandible slender, about twice as long as basal width, cutting edge obliquely emarginate; mentum not defined posteriorly, sunken. Pronotum oblique, anteriorly chitinized, posteriorly covered with coarse recurved asperities; eusternum roundly trapezoidal, usually asperate, distinet; ampullae finely asperate, bearing two transverse impressions meeting distally; epipleurum protuberant on all segments, tubercles oval, multisetose, no chitinous pits. piracles broadly oval, peritreme rather heavy; no caudal armature.

The species of Saperda are easily recognized as larvae in which the body armature of chitinous asperities has reached its highest development. This characteristic seems to be confined to those species or genera in which the larvae attack living tissue and is no doubt more of an adaptive character than almost any other. This armature superficially would confuse them with Oberea, Mecas, and such genera, but they suggest quite a different relationship and appear to have branched from a Goes-like stock.

Taken as a whole, the species feed principally on living plants and, as would be expected, are very strictly confined to a certain host. A wide variety of habits is exhibited, from gall-making to bark, sapwood, and heartwood feeding. In this case the causation of galls is probably due only to the smaller size of the branches attacked, in which the tissues are more readily affected, for in the same species, when it attacks thicker branches, the swelling is often scarcely noticeable. The galleries are rather loosely packed with fibrous frass.

The adults of any species live for a long time and feed on the midribs of leaves and the bark of young twigs.

Felt and Joutel (10) have admirably diseussed the habits of this genus.

\section{KEY TO THE SPECIES OF SAPERDA}

\section{The following key will aid in separating the larvae of the known species:}

Proeusternum bearing few or no asperities; sternellum bearing very few............. Proeusternum bearing at least three rows of asperities extending over half or entirely across the area; sternellum densely asperate.

1. Asperities of pronotum of the same texture throughout; proeusternum and sternellum bearing no asperities; breeds in vines of Virginia creeper (Ampelopsis)............ puncticollis

Asperities of pronotum diminishing in size posteriorly; at least some on prostelnellar area.. 2

2. Asperities in a continuous band of several rows across prosternellum, these very coarse; body

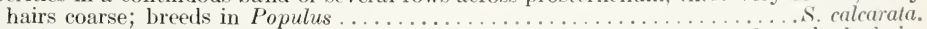

Asperities of prosternellar area in two groups of only one row each, these finer; body hairs finer.

3. No asperities on proeusternum; breeds in the trunks of Salix...............................

Few asperities present on proeusternum . . . . . . . . . . . . . . . . . . .

4. Asperities on eusternum in a single transverse row; causes galls on twigs of Salix and Populus. Spiracles twice as long as wide. . . . . . . moesta

Spiracles not as long as wide.............................

Asperities on proeusternum in two very small groups; pleural tubercles finely rugulose ;

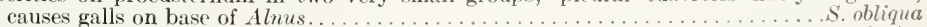

5. Asperities of pronotum coarser, extending over two-thirds to threc-fourths the length (to border of hairs); body hairs coarse, stiff, light eastaneous . . . . . . . . . . . . 6

Asperities of pronotum finer; extending but little more than one-half the length; body hairs very fine, whitish. .

6. Asperities of proeusternum extending over about two-thirds the breadth.

Asperities of proeusternum extending entirely aeross

S. candida

7. Mesonotum bearing a continuous transverse band of dense, fine hairs; peritrome of spiracles thin; breeds under bark of II icoria.

Mesonotal hairs sparse or not continuous; peritreme of spiracles thick

s. Median dise of dorsal ampullae elliptical; lives in base of II icoria and rarely Quercus.

Median dise of dorsal ampullae litte wider than long; asperities nore sparsely ...... lateralis

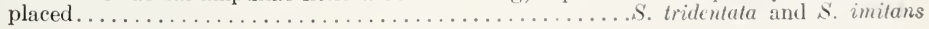


SAPERDA CALCARATA SAY.

[1' XXX, fig. 3; Pl. XXIX, fig. 4; Pl. XXXVI, figs. 3 and 4]

Iarge, rolust; integument fincly rugulose, clotherl with coarse, castaneous hairs; labrum semicmrolar, wilest at base, densely and coarsely haired; pronotum slightly willer than long, asperIties very course, extenling over three-fourths of length; eusternum coarsely haired, bearing a very feu (about 20) asperities; sternellum having a very narrow band entirely across. Ampullae coarsely asperate; pleural tubercle bearing two strong setae and fine pubescence. Spiracles oval, peritreme strongly ehitinizerl.

l'upa. Form as in adult; heal bearing stiff setae on inner margin of eyes, a transverse row at hase of rlypeus and about base of antennae; anterior median two-thirds of pronotum, seutellum mesonotum, and posterior median disc of metanotum bearing a few short, setigerous chitinous points, such points also occur on abdominal terga in a seattered transverse band more numerous at sides and increasing posteriorly, on lateral ventral parts of last segment very dense.

[Described from specimens Hopk. U.S. 10075n.]

The larva of this species is a very serious pest to Populus throughout the castern United states and Canada and west through the Rocky Mountain region. The eggs are laid in June and July on the trunks or larger branches of trees. They are inserted into the cambium in an irregular hole gnawed through the bark. For the first season the young larvae extend transverse galleries between the bark and wood which often entirely cut the cambium, killing the tree. During the second and third seasons large extensive mines are made in the heartwood, where pupation takes place. The trees are so honercombed that great numbers of them break off in the wind. A knotty swelling is often caused at the point where the young larvae are feeding. Piles of frass several inches leep are noticed below infested trees.

\section{SAPERDA HORNII Joutel}

[Pl. XXIII, fig. 9]

Less robust than calcarata; integument smooth, shining, thickly clothed with fine whitish pubescence; labrum semicircular, finely and densely haired; pronotum slightly wider than long, asperities extending over three-fourths of length; eusternum densely haired, no asperities; sternellum bearing only a few asperities on median region; ampullae coarsely asperate; pleural tubercles bearing two long slender setae and fine pubescence; spiracles narrowly oval, peritreme heary.

[Described from specimens Hopk. U. S. 9584.]

The habits of this species are similar to those of $S$. calcarata. It is found only in the Pacific Coast region. Adults were observed ovipositing at Yreka, Cal., in 1911, on young willow (Salix) trees. Three to four eggs were placed in a single egg-sear at equal angles from one another. The young larvae often devoured one another, so that rarely more than a single one developed. The trees were thickly covered with egg scars and were killed by the young larvae before fall. The larvae construct long, straight galleries in the heartwood at the top of which the pupal cell is constructed. Observations by the author.

\section{SAPERDA PUNGTICOLLIS Say.}

Form rather slender; integument very finely wrinkled, rather densely covered with very light castaneous hairs; labrum thin, transversely oval, sparsely haired; pronotum distinctly wider than long; asperities of same texture throughout, extending over but little more than one-half the length; eusternum densely and coarsely hairy in front, no asperities; sternellum bearing a very few (scarcely visible) asperities on lateral extremities; asperities of ampullae very fine; pleural tubercles suborbicular, many setae; spiracles small, oval, peritreme strongly chitinized.

[Deseribed from specimens Hopk. U. S. 10398.]

The larvae kill the vines of Virginia creeper (Ampelopsis). They mine under the bark, pupating in the sapwood. The adult has been collected on Rhus toxicodendron and may live in this vine. Range, throughout the eastern and middle western United States. Observation by A. B. Champlain and the author. 


\title{
SAPERDA CONCOLOR LeConte
}

\author{
[Pl. XXIII, fig. 10; Pl. XLI]
}

Form slender; integument smooth, shining, elothed with fine, long, whitish hairs; labrum transversely oval; anterior margin of head finely granulate; pronotum about as wile as long, asperities finer, extending over three-fourths the length; eusternum bearing a single row of asperities, and sternellum a few on median area; ampullae finely and rather sparsely asperate; pleural tubereles bearing two long slender setae; spiracles oval, peritreme strongly chitinized.

Pupa. Form as in adult; no chitinous points on thoracie segments and but few on abdominal ones; setae fine and slender.

[Described from specimens Hopk. U. S. 9783a.]

The larva of this species eauses a gall from $1 \frac{1}{2}$ to 2 inches in diameter on the young stems of Populus and Salix. The larva mines under the bark and into the wood, completing its burrow by a short, straight gallery in the wood parallel to the stem. Pupation occurs at the top of this chamber. Range, throughout the eastern and central western United states and Canada.

\section{SAPERDA MOESTA LeConte}

The larva of the species closely resembles concolor, but the body asperities are eoarser and the spiracles are more narrowly oval.

Pupa. Distinguished from coneolor only by the stronger asperities on abdomen.

[Deseribed from specimens Hopk. U. S. 12322.]

Mr. Josef Brunner records this species as attacking and killing young trees of Populus trichocarpa at Riggins, Idaho. Pupae, adults, and parasites were found in March, 1914.

\section{SAPERDA OBLIQUA Say.}

Form rather robust; integument very finely wrinkled, elothed with fine, whitish lrairs; labrum subtrapezoidal, widest behind, elothed with very short dense hairs; pronotum wider than long, asperities extending over three-fourths the length; eusternum bearing a group of very long, slender hairs, asperities in two small groups of about ten each; sternellum bearing two small median groups of asperities; ampullae finely and sparsely asperate; pleural tubereles finely rugulose, broadly oval, bearing two long setae; spiraeles narrowly oval, peritreme strongly chitinized.

Pupa. Form as adult; stiff hairs on head about base of antennate and at inner margin of eyes, two longitudinal rows at base of elypeus, and several on tip of labrum; setigerous chitinous points distributed as in calcarata, but much smaller and setae slender; no armature on seutellum or metanotum.

[Deseribed from specimens Hopk. T. s. 1092sa.]

This larva has been found only in the base of Alnus, where it makes a large gall, often killing the bushes. Its work resembles that of the other gall-making forms. The larvae mine under the bark, later through the woot, and finally a straight upward burrow is made at the top of which pupation takes place. The adults are found throughout the central and eastern Inited states chring May and June. When found it is locally abundant.

A tachinid parasite was found killing about 50 per cent of the larvae at Charter Oak, Pa.

\section{SAPERDA CANDIDA Fabricius}

\section{[Pl. XXIV, fig. 15]}

Large. robust; integument very finely wrinkled, shining sparsely clothed with coarse, light, castaneous hairs; labrum eoriaceous, semicireular, about twice as wide as long, coverel with short stiff hairs; pronotum strongly ehitinized, asperities eoarse, extending over three-fourtlis of length; eusternum eoarsely haired, asperities in a lenticular group, not quite reaching lateral limits; sternellum strongly asperate for its entire width; ampullae rather coarsely asperate; pleural tubereles oval, bearing two strong setae and usually two finer ones; spiracles very large, broadly oval to nearly orbieular.

Pupa. Form as in adult; immediately reeognized by presence of a few small chitinous points on head, those on body strong; setae coarse, irregularly disposed on pronotum, a group on scutellum of mesonotum and in a V-shaped group on metanotum; a lense transverse row across abdominal terga.

[Described from speeimens Hopk. IT. S. 9776.]

$57951-9$ 
The habits of this species have heen much cliseussed in literature as injurious (o) fruit treces, apple (Mulus), peach (Amydalus), cte., one of the latest popular areounts being that of Brooks (3). The author has found it in a dense wood in the mountains of Pennsylvania, feeding in the base of living Crataegus. The mines are extended unker the bark, and later a straight gallery from 4 to 6 inches long is extended up through the sapwood before pupation. Range, throughout the castern and central western United States and Canada.

\section{SAPERDA VESTITA Say.}

Vory similar to candida; body hairs sliglitly finer; asperities eoarser; labrum not coriaceous, fincly laired; asperities extending entirely across eusternum, hairs, whitish; pleural tubereles bearing four or five setae; spiracles narrowly oval, peritreme strongly chitinous.

[1)escribed from specimens Hopk. L. S. 11s:3s and 11s47r.]

The habits of this species are somewhat variable, as it attacks both dead and living trees, but so far it has been found only in Titia. Felt and Joutel (9) state that it feeds only on bases of trees, but the writer has observed it in limbs high from the gromul. A great part of the larval mine is constructed under the bark. It is very injurious, often causing the death of the trees. Range, eastern United Ntates and Canada.

\section{SAPERDA DISCOIDEA Fabrieius}

\section{[Pl. XLIV]}

Rather larger; integument smooth, shining, very densely clothed with fine whitish, silky hairs; labrum widest about middle, densely hairy in front; asperities of pronotum finer, covering little more than one-half the length; a continuous band aeross eusternum and sternellum but not reaching lateral limits in eusternum; pleural tubereles bearing many slender setae; spiracles rather large, oval, peritreme not strongly ehitinous.

Pupa. Form as in adult; setigerous points arranged as in other Saperda pupae, but these long and slender; on posterior area of pronotum a V-shaped group oceurs, as also on metanotum; a single transverse row on each abdominal tergum and eight to twelve, on last abdominal segment these long.

[Described from specimens Hopk. U. S. 7517.]

The larvate feed almost entirely in Hicoria, although W. F. Fiske, at Tyron, N.C., records it from Juglans. It is a very serious pest to trees weakened by the hickory barkbectle (Scolytus quadrispinosus say), often attacking them simultaneously with this insect. The mines are extended ahmost exclusively between the bark and wood, pupation taking place either in the sapwood or bark. Normally the larva matures and transforms in one year. The adults are collected from April to late July throughout the eastern United States and Canada.

\section{SAPERDA LATERALIS Fabricius}

[Pl. XVI, fig. 9]

Differs from discoidea in that the body is much less hairy; integument very finely wrinkled; spiracles more strongly chitinized and the asperities on ampullae coarser; median dise of ampullae elliptical.

[Described from specimens labelled State College, Pa., Mar. 16, 1912.]

This is also a dead-wood feeder, mining between the bark and wood. It is rather an omnivorous species for the genus, living in Hicoria, Ulmus, Tilia, Acer, Fraxinus, Quercus, and Prunus, but more commonly in Hicoria. Very moist wood, preferably at the base of trees, is preferred. The larvae mature in one year. Range, throughout the eastern and central United States and Canada.

\section{SAPERDA TRIDENTATA Olivier}

Integument smooth, shining; more hairy than lateralis, the median dise of dorsal ampullae little wider than long, and asperities more sparsely plaeed; otherwise similar.

Pupa. Form as in adult; remarkable for very long, stiff setae on head; points small and irregularly disposed on thoracic terga, but setae eoarse; abdomen as in discoidea, but points shorter and setae coarser; a group of hairs on apical angle of femora.

[Described from specimen labelled Belle Vernon, Pa., Mareh 30, 1912.] 
The larva feeds between the bark and wook of cleat, dying, and living Clmus, often causing serious injury and death. The work resembles that of discoidea and lateralis. Trees which have just been felled are preferably attacked. Pupation takes place either in the sapwood or bark. Range, throughout the eastern and central United states and Canada.

SAPERDA IMITANS Felt and Joutel dentaia.

Integument dull, very finely granulate; nearly as hairy as discoidea, otherwise similar to tri-

Pupa. Resembles tridentata in the strong chitinous points and long setae arising from the base; on the anterior margin of the pronotum is a row of such points and a $\mathrm{V}$-shaped group on posterior half as well as on mesonotum and metanotum; the abdominal terga bear two groups in a transverse row, and a border around last abdominal segment.

[Described from specimens Hopk. U. S. 11845r.]

This species, usually considered rare, has been taken rather abundantly by W. S. Fisher, A. B. Champlain, and H. B. Kirk at Harrisburg, Pa. They record it from Salix, Hicoria, and Tilia. It has also been taken by the writer in Prunus. The larva mines between the bark and wood, pupating in the sapwood.

\section{ONGIDERES Serville}

Cylindrical, semi-robust species; head rather thick but depressed, sides parallel, then suddenly converging to base; epistoma bearing a transverse row of carinae; antennal annulae open (rarely apparently closed); mentum distinet, very slightly sunken, narrow, transverse; maxillary palpi, very slender; posterior area of pronotum elliptical, embosssd, white, finely striate; eusternum distinct; ampullae bearing two rows of regular tubercles (and rarely an irregular middle row); epipleurum protuberant on nearly all segments, tubercle oval, no chitinous pores; no caudal armature.

The described species can be separated as follows:

\section{KEY TO THE SPECIES OF ONCIDERES}

Last joint of maxillary palpi as long as or longer than second; posterior row of tubereles on last ventral ampullae normal.

Epistomal carina coarse, about ten on each side of median suture.

Epistomal carina fine, about twenty on each side of median suture

Last joint of maxillary palpi shorter than penultimate; posterior row of tubercles on last

ventral ampullae chitinous

O. putator.

The larva of only one genus of the large group to which it belongs has been studied; as such the affinities are well marked in two directions. The cylindrical form, thickened, somewhat salient head, embossed pronotum, two rows of tubercles on ampullae, and absence of chitinous pits on pleural tuberele show an intermediate position between such genera as Psenocerus anc Eupogonius on the one hand and Ataxia and Hippopsis, etc., on the other. The antennal cavity seems to be variable in this genus. In cingulata it is apparently closed, but in other species distinctly open.

The adults of this genus, so far as known, have the peculiar habit of girdling the twig in which eggs are deposited. These hranches, breaking off, fall to the ground, so that the larvae have dead wood in which to feed. The galleries are constructed under the bark, the larvae eating much of the rood, or in large twigs penetrating entirely into the centre. The frass is pushed out and the burrow left open. Pupation take place in the late summer. These species often become very injurious, completely deforming the tree.

\section{ONCIDERES CINGULATA Siay.}

\section{[Pl. II, fig. 9; Pl. XIII, fig. 3; Pl. XXXI, fig. 5; Pl. XXXII, fig. 2]} hairs.

Form cylindrical semi-robust; integument smooth, shining, sparsely clothed with whitish silky

Head rather thick, somewhat salient, sides converging behind, often slightly constrieted; epistoma abruptly raised, bearing a transverse row of short longitudinal carinae; clypeus and labrum thin, latter broadly oval, narrowed behind; anterior margin finely ciliate; mandibles short, little longer than basal width, shining, cutting edge very obliquely truncate; antennal 
cavity angulate belind; one pair of small black ocelli. Ventral mouth-parts rather fleshy; mentum distinet, narrowly transverse, very slightly sunken; maxillary palpi very slender, last jomt acute, slender, longer than second, shorter than last labial; anterior eflge of hypostoma not distinct in midelle, transversely slightly bulging; gula indistinet.

I'rothorax subrectangular, thick; pronotum not well defined at sides, posterior area elliptical, embosind, white and fincly striate, anteriorly smooth, shining, laterally with a few fine silky hatrs; eustermm shining, well defined, triangular; sternellum well defined, shining. Mesonotim dull granulate; metanotum, mesosternum, and metasternum bearing two regular rows of distinct small tubercles.

1betominal segments nearly eylindrical; ampullae very narrow, protuberant, bearing two regular rows of small beadlike tubereles; epipleurum more or less protuberant on seven segments, tubercles oval, abruptly protuberant, several slender setae and no chitinous pits; spiracles very small, orbieular, peritreme thin.

Pupe. Form as in adult; front of head bearing numerous fine hairs, and a dense group at base of antenmae and on mandibles; scape of antennae bearing a recurved fleshy process; pronotum thickly beset with slender hairs as are also the mesonotum and metanotum; abdominal tergit rather densely covered with small, ehitinous, setose points, much thicker on caudal segments.

[1)escribed from specimens labelled Hummelstown, Pa., May 24, 1912.]

It is a peculiar circumstance that the pupa of $O$. cingulata has the welldeveloped spine at base of antennae, while it is absent in the adult of this species, although well developed in adults of some of the larger species.

This insect has been recorded from Hicoria, Diospyros, Llimus, Populus, Nyssa, Tilia, Gleditsia, Cornus, Malus, and Pyrus throughout the eastern and southern United States. The adult flies from late July to September. W. F. Fiske has made some interesting observations on this species at Tyron, N.C., and states that "about ninety per cent of girdled twigs are hickory; persimmon is next favoured. The adults often cut off entirely young seedling trees in the forests. Those twigs which were buried in moist humus are the ones from which adults emerged, while in a large percentage of those cut the larvae died. The adult feeds on the bark of young twigs."

\section{ONCIDERES sp.}

Similar to $O$. cingulata, except that the carinae across the epistoma are very fine, averaging about twenty on each side of the median suture, while about ten occur in cingulata. Body clothed more densely with fine hairs, especially on last abdominal segments.

[Described from specimens Hopk. U. S. 10513a.]

Habits similar. This species has been reared from girdled twigs of Prosopis and greasewood (Sarcobatus).

Range, throughout the southwestern United States. Observations by G. Hofer and M. Chrisman.

\section{ONGIDERES PUTATOR Thomson}

\section{[Pl. XII, fig. 3]}

A much more robust species, hairs coarser; mandibles more slender; epistomal carina coarser than in cingulata; last joint of maxillary palpi not as long as second; eusternum densely hairy; dorsal ampullae bearing three rows of large tubercles, middle row irregular, last ventral ampullae having posterior row of tubercles, chitinized.

[Described from specimens in the U. S. National Museum taken in the branches of Siderocarpus flexicaulis, from Brownsville, Tex., by H. S. Barber.]

\section{It also attacks Acacia and Prosopis.}

\section{ATAXIA Haldeman and ADETUS LeConte.}

Lacordaire (19) has placed Ataxia in a separate tribe and LeConte and Horn (20) have likewise retained this group, placing Adetus in a closely allied tribe. The affinities of these two larvae are very close; in fact they differ only in minor details. The author regards them as belonging to the same tribe, closely allied to the Hippopsini. The assembling in one tribe of these two genera, together with Spalacopis, would constitute a more natural group of larvae than many other larval groups, as they are defined on the characters of the adults. 


\section{ATAXIA CR YPTA Say.}

[Pl. V, fig. 6; Pl. XXIII, figs. 1 and 2; Pl. XVI, fig. 13; Pl. VII, fig. 14; Pl. XXXI, fig. 4]

Form cylindrical, slender, elongate; integument smooth, shining, rather elensely clothed with fine yellowish white hairs.

Head very salient, thick, oval in cross section, sides parallel, then suddenly constricted at base; clypeus and labrum thin, latter fungiform, somewhat stalkel; mandibles about one and one-half times as long as basal width, acute, cutting-edge obliquely emarginate; antennal ring closed; one pair of small black ocelli. Ventral mouth-parts rather thick; mentum little wider than long, not distinct at base, sunken; last joint of maxillary palpi longer than beadlike second, shorter than last labial; palpifer having a small fleshy process on outer face; ligula large; gula not distinet; hypostoma strongly protuberant, posteriorly developed into two obtuse conical protuberances.

Prothorax cylindrical; pronotum defined by complete lateral sutures, posterior area embossed, white, very finely striate, anterior smooth; sternum glabrous except posterior angles, eusternum, and lateral angles of deep sternellum. Mesonotum with $\mathrm{x}$-shaped sutures, lateral triangular areas densely hairy; metanotum, mesosternum and metasternum finely hairy, bearing two rows of tubercles.

Abdomen cylindrical; ampullae very narrow, bounded by two lateral impressed lines, and bearing two rows of regular tubercles; epipleurum protuberant on all segments, tubercles very large, oval, having several setae but no ehitinous pits; ninth segment swollen, very densely ciliate; tergum bearing a chitinous tipped, suddenly constricted spine, tip truncate; spiraeles small, orbicular, peritreme slightly chitinized.

Pupa. Form as in adult; front of head bearing a number of fine setae, and a group on mandible; pronotum sparsely setose, more abundantly on lateral margins; mesonotum and metanotuin glabrous; abdominal terga bearing two transverse patches of dense, chitinous, setose points, much coarser and thicker on seventh tergum; caudal tergum reflexed in a thin broad flange, nearly as wide as segment, ventrally this segment very densely clothed with chitinous setae.

[Described from specimens Hopk. U. s. 10311b.]

specimens from the southern and southwestern States show a form in which the caudal spine is sharply acute instead of truncate, and the ampullar tubercles larger. The pupa of this form has the reflexed flange not one-half as wide as the segments and very few chitinous points on the serenth tergum. (Hopk. U.S. 9901s.)

This species has been reared from Quercus, Castanea, and Pyrus in Virginia. Farther south and into the southwest it attacks a variety of herbaceous or shrubby plants, namely, Xanthium, Terbesina, Ambrosia, Thurberia, Smilax, and cotton (Gossypium). The larvae feed in the dead or, rarely, living branches mining a long, narrow tumnel, sometimes several feet in length. The pupal cell is constructed in the fall by placing two fibrous plugs of frass in the hollowed chamber. The adults emerge in May and June.

\section{ATAXIA SULCATA Fall}

Form larger hypostomal protuberance much larger and more confluent; posterior area of pronotum faintly striate; tubercles of ampullae large and distinct, posterior row of last vint ral ampullae bearing two large projecting tubereles, while those of anterior row are elongate, oval; caudal spine deflexel, acute.

Pupa. More hairy than A. crypta, especially on the thoracic segments; chitinous setose hairs of the abdominal terga more slender, and on anterior margin of third and fourt li abcominal terga two groups of two or three chitinous spines; flange on last tergum bearing a small point in the middle and the extremities projecting much higher than the middle

These larvae (Hopk. U. S. $10081 w$ and 11935) collected by T. E. snyder from the seeds of mangrove (Rhizophora mangle) in Florida, closely resemble those of Ataxia crypta. The adults are much more robust.

\section{ADETUS SUBELLIPTICUS Bates}

[Pl. II, fig. 8; Pl. XXIV, fig. 5; Pl. XVI, fig. 10; Pl. VII, fig. 13]

Form cylindrical, slender; sparsely clothed with fine yellowish-white hairs.

Head similar to that of Ataxia, but protuberances on hypostoma not so sharply conical.

Prothorax eylindrical; pronotum rectangular, entirely smooth, shining, somewhat chitinized or posteriorly indistinetly striate; alar area a chitinous plate; sternum trapezoilal, willest in front, laterally bearing an oval chitinous spot; eusternum elliptical; sternellum well defined; mesonotum bearing $\mathrm{x}$-shaped suture, with the lateral clliptical areas well defined; metanotum bearing two regular rows of large tubercles; mesosternum not tuberculate, metasternum bearing a few large irregular ones. 
Ablomen evlindrieal, segments short; seven ampullae bearing large regular tubereles, the first thee of two rows, the remainder of one, posterior row of about five or six tubereles, ventral smol:11; (p)iplentum protubermi on all segments, tubercles large, clongate oval, ehitinous pits not distinct; ninth segment swollen, clenscly ciliate, tergum produced into an inflexed conical, chitinous tipperl mocess.

These larvae in the UT. S. National Museum were collected and adults reared by Mr. E. 1. schwarz in a cucurbit vine from Panzos, Guatemala.

\section{IIIPPOPSINI}

This remarkable tribe, represented by four North American genera, the larvate of two of which have been found, are strikingly aberrant forms. At first appearance the larvae would rarely be taken for cerambycids. The salient, oval head having the foramen situated almost posteriorly, the protuberant mesosternum and metasternum, the peculiar ampullae and the swollen ninth abdominal segment immediately characterize this group. They are evidently related to Ataxia and to the larvae of the European genus Agapanthia, from which it differs only in minor details. Our genera are pith feeders, mostly in herbaceous stems, and are very active, crawling up and down the hollowed stem with great rapidity. On being exposed they squirm and wriggle actively.

HIPPOPSIS LEMNISCATA Fabricius

[Pl. XIII, fig. 7; Pl. XXIV, fig. 13; Pl. XVII, figs. 17 and 18; Pl. VII, fig. 11; Pl. XXXI, fig. 1; Pl. II, fig. 13.]

Form very elongate, slender, eurved, eylindrical; integument very finely granulate, shining, very sparsely elothed with hairs.

Head extremely salient, oval in eross-section, sides parallel until suddenly eonstrieted at base, foramen posterior and ventral; elypeus and labrum thick, latter transversely fungiform, stalked, sparsely haired; mandibles short, triangular from side, little longer than basal width apex bidentate, dorsal angle abruptly toothed; antennal ring elosed; one pair of small ocelli. Ventral mouth-parts thick, sunken; mentum distinet, about twice as wide as long; last joint of maxillary palpi longer than second, equal to last labial, second transverse; hypostoma bulging; no trace of gula.

Prothorax cylindrical; protergum smooth, shining; pronotum not defined by lateral sutures, slightly chitinized; prosiernum uniformly chitinized, glabrous; eusternum and sternellum rather firmly fused, indicated by two transverse foveae. ISesonotum smooth; metanotum obseurely tuberculate in two rows; mesosternum and metasternum strongly protuberant, a transverse row of setae between sternum and sternellum.

Abdominal segments elongate, eylindrieal; no ventral ampullae, dorsal strongly protuberant, composed of two transverse, finely striate ridges; epipleurum somewhat protuberant on all seginents, pleural tubereles distinct only on eighth, bearing two strong setae; ninth segment swollen, very densely eiliate, sternal area protuberant; spiracles orbicular, searcely ehitinized; no caudal process.

Pupa. Form as in adult; head having a dense group of setae at base of antennae; lateral margin of protergum ciliate; thoracic segments glabrous; abdominal terga armed with minute chitinous points, except for a transverse glabrous band, posterior margins with a closely set row of flat setae.

[Deseribed from speeimen Hopk. U. S. 9784c².]

The larvae have been collected in the stems of Ambrosia, which they completely hollow from the top to the surface of the ground. In a cell at the base the larvae pupate. The life cycle is completed in one year, adults emerging in June and July. Observations by A. B. Champlain, and the author. R. W. Van Horn records taking an adult under bark in December at Great Falls, Va.

SPALACOPSIS STOLATA Newman

[Pl. VII, fig. 16]

Very similar in form to Hippopsis. Head more strongly narrowed posteriorly; lateral sutures of pronotum impressed, posterior area white, shining, embossed; entire prosternum strongly fused and protuberant posteriorly in a rounded projection. Dorsal ampullae six, these bearing two rows of regular tubereles, ventral ampullae absent exeept on sixth and seventh segments; ninth abdominal segment swollen, densely ciliate; tergum bearing a fleshy, cylindrieal projection, obliquely truncate, having a ehitinous point on the ventral margin of the truncate face. 
[Deseribed from three poor specimens in the U. S. Nutional Museum coilection trom Sin Mateo, Fla., April 19, 1881, boring in the stalk of Jerusalem oak (Chenopodium botrys). No collector given.]

\section{Group PHYTOCCIDES}

In this group Lacordaire (19) has placed a number of genera, including, among other North American forms, Oberea, Mecas, and Tetraopes, of which the larvae are known. He has placed Tetraopes in a division of equal rank with Oberea. Tetraopes may be related to Oberea, etc., but it has become so peculiarly adapted to its environment (root-feeder) that it is difficult to say where the larvae should be placed. The head in no respect suggests Oberea, but more nearly a Saperda, and it is here regarded as a development from such a type. In general form it suggests Monilema.

Mecas likewise has assumed a root-feeding habit, but the larva confines itself more strictly to the inside of the root. The characters of the head clearly show its affinities to Oberea, and if Tetraopes was related to these genera it would no doubt still retain the peculiar conical type of head.

Mecas and Oberea larvae seem more closely allied to Ataxia and Hippopsi like forms than to any other Lamiinae.

TETRAOPES TETRAOPHTHALMUS Forster

\section{[Pl. V, fig. 4; Pl. XII, fig. 2; Pl. XVI, fig. 11; Pl. XXXII, fig. 1]}

Form robust, fleshy, eylindrical or slightly tapering posteriorly; integument very 1 me y wrinkled shining, densely clothed with long, whitish lemon-coloured hairs.

Head rather thick but depressed, sides narrowing posteriorly, suddenly constricted about middle, widest across posterior limit of front; epistoma hick, rugulose; clypeus and labrum thick, latter transverse, roundly semicircular from base, densely haired; mandible from side about twice the basal width, outer face rather rugulose, eutting-edge obliquely truncate, dorsal angle distinetly toothed; antennal cavity bisected by frontal suture; ocelli not distinet. V'entral mouth-parts fleshy; thick; mentum distinet, transverse; maxillary palpi two-jointed, last joint slender, shorter than the basal, equal to the last labial; hypostoma transversely bulging, finely wrinkled; gula less corneous.

Prothorax very thick, about twice as wide as long; protergum densely hairy on sides and across anterior border; pronotum posteriorly finely velvety pubescent; prosternum densely hairy, lateral areas swollen; eusternum distinet, swollen; sternellum very narrow, transverse. Mesonotum and metanotum densely hairy, mesonotum with an anterior transverse band of hairs, posteriorly glabrous.

Abdomen very densely hairy; ampullae narrow, projecting in large, dull tuberculiform lobes; epipleurum slightly protuberant on all segments, tubercles elongate oval, bearing very many hairs and no chitinous pits; spiracles large, orbicular.

The larva feeds in the base of stems and roots of Asclepias. It more usually does not enter the root but burrows in the earth and eats from without the root often only eating the bark, much like some scarabaeids. (ralleries were found extending from root to root through the earth, then continued up to near the surface of the ground, where pupation occurs. Infested plants can be recognized by withering tops in late summer. The adult occurs throughout the eastern United states and Canada. in June and July.

The tendency to develop a strong, dense body covering of hairs is true of all forms having somewhat similar habits, while the opposite extreme is represented in those forms which mine in living tissue and develop the strong chitinous asperities.

\section{OBEREA Mulsant}

Head thick, eonical, sides strongly converging posteriorly, ending rather acutely; antennal annulae elosed; mandible shortly tringular; mentum indistinet posteriorly, transverse; palpi rather short; pronotum very oblique, posterior area strongly asperate, laterally bearing a deep, oblique suleus; eusternum roundly trapezoidal, large; ampullae very finely asperate, bearing two transverse impressions, one rather indistinet; epipleurum protuberant on all segments; tubercles without chitinous pits; spiracles oblique, lenticular; no eaudal armature.

So far as known, all attack living plants, usually the smaller branches, which they completely hollow and kill. The eggs of many species are laid 
neal the top of the branch or stem just beneath a spiral incision which girdles and kills the tip). This girlling suggests Oncideres. The most characteristic fouture of their work is a series of circular holes extending througl the bark in a straight line along the branch, from which the frass is expelled. In this respecet they resemble some of the species of Elaphidion. The larvae are very active in their open burrow, moving with remarkable rapichty by the use of the strongly protruding ampullac, armet with asperities. The pupal cell is constructed by plugging off a chamber of the mine by two fibrous wark of frass.

The species of Oberea are very difficult to separate as larvae. Beside the usual ocellus near the antemnae these larvae have several secondary ocelli farther lack on the head. These ocelli are merely pigment spots beneath the chitin and rarely protrude. They have been used as descriptive characters, but might he found to be variable if a large series were stuched. There are many varieties of the species described, and it is probable that when the biology of more of these is known they can be ranked as good species.

\section{KEY TO DESCRIBED SPECIES OF OBEREA}

Asperities of pronotum covering one-half or more the length, i.e., from posterior asperities to anterior row of hairs.

Outer face of mandible, near base, granulate...................... ocellata

Outer face of mantlible smooth.

Three secondary ocelli; asperities of ampullae coarser (see description).

Two upper secondary ocelli approximate, just behind prinary; feeds in the branches of Sall $x$.

O. ferruginea

Secondary ocelli not so placed; feeds in the twigs of Populus............. schaumii

Two secondary ocelli; asperities of ampullae finer; feeds in stems and base of sassafras .

Asperities extending over less than one-half length of pronotum.

I'sually no secondary ocelli, or rarely one.

O. ruficollis.

Usually three secondary ocelli.

O. tripunctata

O. bimaculata

\section{OBEREA RUFICOLLIS Fabricius}

\section{[Pls. II, XIII, XXIV, XXXII]}

Form very elongate, slender, cylindrical; integument smooth, shining, covered with extremely few short, stiff, yellowish-brown hairs.

Head thick, conical, sides rapidly converging posteriorly; epistoma narrow, abrupt; clypeus swollen; labrum thin, little wider than long, roundly rectangular, thickly haired; mandible from side, short, triangular, cutting edge oblique often having a very small, acute dorsal tooth; one pair of small distinct ocelli; antennal ring closed. Ventral mouth-parts thick, rather fleshy; mentum distinct, transverse; maxillary palpi conical, last joint acute, equalling second and shorter than last labial; hypostoma narrow, transverse, anterior edge deeply eurved and sunken; gula not distinet.

Prothorax. Pronotum very oblique, long and narrow, anteriorly smooth, shining, ehitinized, posterior one-half strongly asperate, the asperities flat, reflexed, becoming smaller posteriorly, just inside lateral suture a strong, deep, oblique fovea; paranotum shining, glabrous, almost perpendicular; prosternum narrow, transverse, lateral areas chitinized, extending behind sternellum; eusternum large, roundly trapezoidal; sternellum very narrow. Metanotum, mesosternum, and metasternum very finely asperate.

Abdomen elongate, cylindrical; ampullae very narrow, abruptly projecting, having a deep posterior suture and less distinet anterior transverse one meeting distally, surrounding folds very finely asperate; epipleurum strongly protuberant on all segments, tubercles oval, bearing two setae, no chitinous pits; spiracles oblique, lenticular, chitinous rimmed.

Pupa. Form like that of adult; a group of short, stiff hairs on dise of pronotum; a v-shaped row of hairs on metanotum; each abdominal tergum bearing a few strong, chitinous-tipped papillae; epipleurum bearing two strong, reflexed, chitinous, tipped papillae.

[Described from specimens Hopk. U. s. 9729.]

The larva feeds in the stems and roots of young living sassafras one-half to two inches in diameter. The eggs are laid at the tip of a small branch just beneath a small portion girdled by the adult. The larvae work downward through the centre of the stem to the base and thence often deep into the root. The entire gallery, often several feet long, is kept open, the larvae crawling 
about in it and when disturbed entering the root. At intervals along the stem the perpendicular holes are opened to the surface through which the frass is exuded. These holes are evident long after as sears on the trees. Pupation takes place near the surface of the ground during May and June. The work of this insect is very abundant through the eastern United States and often causes extensive death of the younger growth. Two or three years are required to complete the development.

\section{OBEREA FERRUGINEA Casey}

This is a more slender form than ruficollis; body hairs coarser and darker brown; secondary ocelli three, irregularly placed; asperities of pronotum covering one-half the length from posterior asperities to anterior border of hairs; asperities of ampullae much coarser, individually distinguishable with a strong hand lens, while in ruficollis they are not so distinguishable.

[Deseribed from specimens Hopk. U. S. 10072a.]

These larvae were collected by A. B. Champlain in the branches and twigs of Salix at Colorado Springs, Colo. The larval work is not so characteristic as with other species, as often the holes for extruding frass are absent. The egg scar of the adult resembles an elongate print of a horse's foot.

\section{OBEREA SCHAUMII LeConte}

Similar to ferruginea exeept that the two upper secondary ocelli are set very close together and directly behind the primary ocellus.

[Described from specimens Hopk. U. S. $9906 r$.]

These larvae were reared from Populus twigs submitted by a correspondent from Wellington, Kans. The work resembles that of ferruginea. Riley (28) described the habits of this species.

OBEREA OCELLA'TA Haldeman

[P1. XLIV]

More slender than ruficollis; asperities of ampullac a little coarser and body hairs much coarser and darker in colour; readily recognized from all other species by the granulate outer face of mandible; two secondary ocelli, the upper situated farther posteriorly, the other below so as to form an equilateral triangle with primary.

[Described from specimens Hopk. U. S. 9791 $\mathrm{c}$ and 10080k.]

This larva has been found in two species of Rhus. The work in all respects resembles that of ruficollis, but the larva bores more extensively in the roots. Two years are required for the larva to mature. The adult flies while the laurel is in bloom. Observations by J. J. Davis, A. B. Champlain, H. B. Kirk, and the author.

\section{OBEREA TRIPUNCTATA Fabricius}

\section{[Pl. XLIV]}

More slender than ruficollis and the asperities of pronotum extending not more than onethird the length; secondary ocelli usually one or often indistinet.

Pupa. Searcely distinguishable from that of ruficollis exeept by the smaller size and the finer chitinous papillae on the abdominal terga.

[Deseribed from specimens Hopk. U. s. 9749.]

The larvae mine and girdle small living branches of plum (Prunus), quince (Cydonia), apple (Malus), peach (Amygdalus), Ulmus, and Cormus. The eggs are placed just beneath the girdled tip near the end of the branch, through this branch the larvae mine, hollowing it out and eventually causing it to break off, though it is not cut in the same sense as by Elaphidion zillosum. Nuncrous small holes are cut to the exterior along the hollowed portion. Fruit trees are sometimes seriously damaged. The adult emerges during May and Jume. It occurs throughout the eastern United states. Ruggles (29) gives a good account of the life history. 
OBEREA BIMACULATA ()livier

[Pl. XVI]

This larva camnof ne distinguished from that of tripunctata exeept that on all forms examined three secondary oedli are present.

[1)ereribed from specinens in the L. S. National Musem labelled as from raspberry (Rubus), Rome. N.Y., ()etober 1, 1S72.]

The habits are similar to those of tripunctata.

\title{
MEGAS PERGRATA say.
}

\author{
[Pls. XVI, XXXIII]
}

Form short, somewhat robust, eylindrieal, tapering posteriorly; integument finely granulate to wrinkled, sparsely clothed with rather stiff hairs.

Ilead thick, conical, tapering posteriorly; eylpeus rather narrow; labrum broadly oval, anterior margin beset with short golden hairs; mandible shortly triangular, cutting-edge very oblique, dorsal angle sharply toothed; ocellus distinct; antemnal ring closed. Ventral mouthparts thick, fleshy; mentum not defined posteriorly, transverse; maxillary palpi conical, second joint shortest, last shorter than last labial; anterior edge of hypostoma deeply curved; gula not distinct.

Prothorax quadrangular; similar to that of Oberea except that no asperities are present on the ventral surface. Mesothorax and metathorax having no asperities or tubereles.

Ampullae very narrow, projecting, smooth, shining, dorsal with a lateral short impression and two transverse ones ineeting distally, deeply furrowed in the middle; epipleurum protuberant on all segments, tubercles narrow, oval, bearing two hairs but no pores; spiracles lentieular.

[Deseribed from specimens Hopk. U. S. 1007 1a.]

These larvae have been collected in the stems of wild asters (Aster) from Colorado. The larva feeds in the stems and down into the roots, completely hollowing the latter. Subsequently that portion of the stem of the plant breaks off at the surface of the ground. Small heaps of frass are exuded about the base of the plant. Only one larvae is found in each stem. Observations by A. B. Champlain.

\section{APPENDIX}

\section{ADDITIONAL SPEGIES}

since compiling the data on the preceding species others have come to the author's attention and are here described with notes suggesting their relationship to those in the previous discussion. Several of these are from the United States National Museum collection and the identifications have not been verified; the others have been reared.

\section{ACHR YSON SURINAMUM Linnaeus}

Form elongate, subcylindrical; integument thin, shining, sparsely covered with fine yellowishwhite hairs.

Head subtrapezoidal, about as wide as long (to tip of mandibles), tapering rather strongly in front, mouth-frame chitinized, dark reddish with a much darker semieireular ehitinization on pleurostoma below antennae; labrum roundly trapezoidal, narrowed in front, hairs short; mandible entirely black, basal piece shorter than apical, latter bearing a slight fovea; antennae salient, joints 1 and 3 subequal, second longer; one very small ocellus contiguous with base of antennae; gena receding, not setose; maxillary palpal joints subequal, last equal to last labial, process of palpifer indistinet; hypostoma transversely wrinkled, sutures distinet; gula narrow, slightly longer than wide.

Prothorax trapezoidal, bearing slender fine hairs on sides: pronotum anteriorly strongly and regularly punctate, posteriorly shining, finely reticulate and broken with irregular striae, median suture deep, entire; eusternal plates rectangular, the anterior half punctate, the posterior striately reticulate; extremities of sternellar fold distinet, passing spiracle. Mesonotum and metanotum finely granulate, the latter bearing transverse impressions. Legs small, about equal in size to maxillary palpi.

Ampullae shining, finely granulately reticulate, the dorsal ones bearing two lateral and in front a connecting transverse impression, and two snall foveae on dise; pleural dises distinet on first three abdominal segments, largest on second, consisting of a deep pore surrounded by fine granulations and then by fine striae. Spiracles small, narrowly oval, peritreme thin. Ninth tergum bearing two faint, elongate, chitinous carinae or tubercles.

[Described from specimens Hopk. U. S. $10083 e$ and $10083 w$.] 
The larva feeds in the wood of Cercidium, also Acacia, and Prosopis, working much as does Neoclytus. specimens have been collected by G. Hofer in Arizona.

The presence of chitinous tubercles on the ninth abdominal tergum is very unusual in this subfamily; in fact this is the only species in which it occurs, as far as known. In the key given to the Cerambycinae the larva runs down to the Callidini, from which it can be separated by the eerei. It does not suggest the Callidini, but more closely resembles Malcopterus and is quite distinct from Oeme and its allies.

\section{ACHRYSON CONCOLOR LCCOnte} hairs.

Form elongate, rather slender; integument firm, shining, very sparsely covered with fine whitish

In general similar to surinamum, except that the head is proportionately wider and more triangular, slightly wider than long (length to tip of mandible); buceal margin uniformly darkly chitinized; ocellus larger, contiguous with base of antennae; hypostomal sutures not so distinct; gula not distinct; pronotum posteriorly distinctly striate; ampullae alutaceous, shining, the posterior ventral ones divided in middle by a band of dull granulation; prosternal spots anteriorly punetured, posteriorly rugulose to alutaceous; pleural dises finely granulate, most distinct on second and third abdominal segments; abdominal spiracles narrowly oval, somewhat smaller than ocellus; no cerej.

[Described from specimens Hopk. U. S. 15128.]

These larvae were collected by T. E. snyder at Browns ville, Tex., inlimbs of huisache (Acacia) girdled by Oncideres putator. They feed beneath the bark, pupating in the sapwood. In this same stick of wood 1 foot in length and $1 \frac{1}{2}$ inches in diameter six species of cerambycid larvae were feeding.

\section{AGMAEOPS DIRECTA Newman}

This larva in many respects resembles that of Pachyta monticola. The following characters are present: Three small, distinet ocelli and just behind them, a black pigment spot beneath the chitin; mandibles deeply notehed, almost bidentate at apex; labrum twice as wide as long; dorsal ampullae bearing four rows of very small but distinct tubereles and not asperate; spiracles small, orbicular, the opening situated anteriorly, i.e., the peritreme is very thick and the posterior margin much wider than the anterior margin; ninth segment bearing a short, acute spine, surrounded by a few stiff hairs, the remainder of the body hairs fine and silky.

[Described from specimens Hopk. [T. ... 10625.]

These larvae were secured by eaging adults on various species of wood eut at different dates. The adults oviposited on Liriodendron and Castanca, the resulting larvae boring in the bark. Whether they go into the ground to pupate has not yet been determined.

A large larva in the U.S. Forest Insect Collection (Hopk. I. S. 42+1b), collected by H. E. Burke under the bark of Abies, state of Washington, has nearly all the important characters in common with this species except that the ampullae are not tubereulate but entirely finely asperate. It is hardly possible to base generic characters on the larvae of the few species describer in this paper in the genera Anthophilax, Toxotus, Pachyta, and Acmaeops. Many of the characters run together in the species studied, suggesting that if more material were available good generie distinetions in these larvae could not be drawn or that the larvae would suggest other generic groupings.

\section{ACROCINUS LONGIMANUS Limaeus}

Form elongate, strongly depressed; integument firm, covered with short, rather stiff luars.

Head very strongly depressed, sides regularly and strongly converging posteriorly; epistoma straight; labrum a little wider than long, broadly rounded, widest near base; mandible slender, elongate, length about three times condylar width, cutting-edge shallowly emarginate, antennal ring faintly bisected by frontal suture. Ventral mouth-parts elongate; inentum twice as wide as long, distinct; last joint of maxillary palpus shorter than penultimate, much shorter than last labial; anterior edge of hypostoma straight; gula not distinet. 
Prothorax depresserl: pronotum posteriorly beset with chitinous, conical papillae, as also tro the ampullae; pletul tubereles broarlly oval, having a chitinous pit at each extremity and five or six setae; spiracles boadly oval, peritreme thin.

(1)escribel from several spermens in the Tnited States National Museum collection labelled Ilta lorapaz, (ituatemalis, Ipril, 1906, II. A. Barber, collector.]

This larva has been deseribed previously by Chapuis and Candeze (5), but is here re-elescribed to make the deseription conform to the terminology here used.

Acrocims is undoubtedly closely related to $A$ canthocinus. From the head alone it can seareely be separated, while the peeuliar asperities on the pronotum and ampullae seem to be only a difference of degree from the veluring of Icunthocinus.

\section{CYLLENE INFAUSTA Lee}

Distinguished from the other species of Cyllene by having dull finely granulate ampullae, the posterier margin of pronotum shining (lacking band of velvety pubescence) and large oval conspicuous spiracels; botly hairs coarse, castaneous.

[Described from specimens No. 8294, Dominion Entomologieal Branch.]

These specimens were collected and reared by Mr. Norman Criddle at Aweme, Manitoba. The larvae feed in the roots of Petalostemon candida.

\section{EUCROSSUS VILLICORNIS LeConte}

Form elongate, robust; integument thin, tull, rather thickly covered with short golden-yellow hairs.

Head subtrapezoidal, somewhat depressed; mouth-frame darkly chitinizel; epistoma suddenly emarginate in middle; labrum suborbicular, the dise glabrous; mandible black at tip, basal half lighter and shorter than apical, latter with a slight impression on outer face; one pair of large ocelli enclosed by the strongly shouldered and tuberculate gena; genal setae short, lense; antennae salient, first joint shorter than second, a little longer than third; last joint of maxillary palpi shorter than others, shorter than last labial; process of palpifer distinet, as well as the proeess on first maxillary joint; hypostoma smooth; gula very short, wider than long; no subfossal spine.

Prothorax rectangular, densely and coarsely haired at sides and across anterior margin of pronotum; posterior area of pronotum shining and finely alutaceous, projecting forward in middle, hind margin velvety pubescent, no median suture; eusternal spots large, shining, separated by a fine, dull granulate band. Mesonotum and metanotum dull, very finely velvety pubescent; extremity of sternellar fold distinet, passing beyond spiracles. Legs four-jointed.

Ampullae broad, dull, very finely granulate, dorsal bearing two lateral and two transverse impressions. Pleural dises very large and dull granulate, bearing a very deep pore, distinet on five segments, largest on third; spiracles broadly oval, peritreme very thin.

Pupa. Dise of prothorax bearing seattered, acute, chitinous points, projecting anteriorly; posterior portion of metanotum and each abdominal tergum also bearing much stronger conical chitinous points, projecting posteriorly, arranged on the anterior segments in transverse rows, and the midlde points often set on a chitinized dise; two sinall eurved spines on last tergum.

[Described from specimens Hopk., L. s. 10083g.]

The larvae were collected by F. P. Keen beneath the bark of dead Pinus torreyana at san Diego, Cal. The work resembles that of Callidium antennatum. The atults were reared at Falls Church, Va.

Eucrossus has been placed in the group with Oeme, etc., but the larva appears in all respects to belong to the Callidini. In the keys given here it runs down to Physocnemum, from which it can be separated by the characters given.

\section{IBIDION TOWNSENDI Linell}

This larva more elosely resembles that of Heterachtes than that of Ibidion. It is distinguished from $H$. quadranulatus by the gena not being corneous. Striae of pronotum finer and more regular; prosternal plates fused in middle, forming a transverse triangle and finely striate; pleural disc's distinet on second and third abdominal segments, largest on third; spiracles orbicular, not larger than ocellus, peritreme thin.

Pupa. Head unarmed, pronotum bearing a transverse row of small acute spines at middle, a few on anterior margin, a group of four between these, and two groups near posterior margin; mesonotum, metanotum, and first abdominal tergum unarmed; remaining abdominal terga bearing 6 to 8 small, chitinous papillae, except the eighth, which bears only two longer ones. Tex.]

[Described from specimens Hopk. U. S. 15128, collected by T. E. Snyder at Brownsville,

The larvae were feeding beneath the bark of an Acacia limb girdled by Oncideres. They pupate in the sapwood. 


\section{LAGOCHEIRUS ARANEIFORMIS Linnaeus}

[Pl. XVII, fig. 14]

Form rather robust, sub-depressed; integument rather firm, shining, sparsely elothed with coarse brownish-yellow hairs.

Head depressed, sides very slightly constrieted behind middle; bueeal margin darkty ehitinized and roughened; labrum wider than long, densely haired on anterior half; mandible dull black, over twiee as long as condylar width, eutting edge obliquely emarginate, dorsal broadly projeeting; antennal ring open behind; one pair of prominent oeelli; maxillary palpi slender, last joint shortest, acute, shorter than last labial; ligula widest at apex, truneate; anterior edge of hypostoma curved; gula roughened, not protuberant.

Prothorax rectangular, depressed; pronotum posteriorly finely asperate exeept for a longitudinal median glabrous streak, anteriorly glabrous, shining, exeept for a transverse row of short hairs; eusternum shining and anteriorly hairy. Mesonotum, metanotum, mesosternum, and metasternum having a transverse band of velvety pubeseenee.

Abdomen. Ampullae seven, velvety pubeseent, dorsal bearing two transverse impressions meeting externally; epipleurum protuberant on last five or six abdominal segments, pleural tubercle broadly oval, bearing three to five setae and a chitinous pore at extremities; spiracles very large, oval, peritreme heavily ehitinized.

[Deseribed from specimens Hopk. U.S. 10085b.]

These larvae were collected in quarantine at New York ('ity, in the stems of living Ficus from the Isle of Pines, Cuba. An adult was reared by the writer at Falls Church, $\mathrm{Va}$. The affinities are suggestive of such forms as Acanthoderes and other genera related to Liopus.

\section{OBEREA MYOPS Haldeman}

This larva resembles that of tripunctata and that of bimaculata, falling in that division as described in the key. One distinet secondary ocellus is present and above it a fainter, purplishblack bloteh beneath the chitin. The body hairs are mueh eoarser and darker, those on the epistoma considerably longer than the elypeus; the asperities of the amupllae are longer and stronger than in almost any other species of Oberea.

Pupa. No chitinous points on thoracie terga and very few on abdominal, these becoming stronger and more conspicuous on last three segments; otherwise as in ruficollis.

[Deseribed from speeimens Hopk. U. S. 100sti.]

- These larvae have been found only in Rhododendron and related shrubs. The adult girdles the tip of the stems, inserting an egg in the living portion beneath the girdle. During the first summer the larva bores down the stalk, hollowing out the centre and exuding frass through numerous holes cut to the surface. The second summer the roots are attacked and likewise hollowed, until late summer, when the pupal cell is constructed near the surface of the ground and the stem above is cut off by an oblique incision. The adults fly about the time the host plants are in flower.

\section{OBEREA FLAVIPES IIaldeman}

Resembles the preceding, but two seeondary oeelli usually are clistinet; the asperities of the ampullae are finer and the body hairs as coarse.

This larva feeds in the stems of Phlox, the habits being quite similar in all respects to those of myops. Only one year is required for completing the entire development. Observations by A. B. Champlain and the author in the vicinity of Washington, D.C.

\section{PACIITA MONTICOLA Randall.}

\section{[Pl. I, fig. 3; P1. XXI1, fig. 15]}

For'm elongate, depressed, paralled; integument tough, smooth, shining, sparsely elothed with coarse castaneous hairs.

Other eharacters than those defined under the genus are: Hypostoma transwerse, having anterior edge not distinet from submentum; gula not indicated; anterior half of mesonotum and metanotum dull, finely asperate; tubercles of ampullae irregular, confluent, and finely sparsely asperate; ninth abdominal tergum bearing an acute chitinous spine suldenly turned upwards and immediately surrounded above by six long setae. 
l' ye finm as in adult, beset with groups of redelish-brown hair as follows: I transverse finde on : mberof and posterior nurgin of pronotum; two groups of arching hairs on mesono\{11m, met:motum, amel first four abdomianl terga, more dense on first abdominal tergum, becomme thinner posteriorly and again present on eighth; last segment ending in al sort, acute

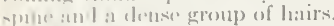

(1) enerolued from specimens IIopk. [. S. 11s13.]

In June, 1917, the author found prepupal larvae in earthen cells 6 inches helow the surface of the ground beneath a liemlock (Tsuga canadensis) log felled 19) months previously. One of the larvae pupated. Adults of Pachyta monticole were found nearby and caged on hemlock boughs. Eggs and, later, larvale were secured which agree in all respects with the prepupal larva, thus comnecting and completing the life history. After mining for about a year beneath the bark, making meandering burrows, the larvae leave by an elliptical hole through the lark and burrow into the ground to pupate.

Similar larvae lave been collected by W. F. Fiske in Abies and Picea. Range, throughout the mountains of the eastern United states and Canada.

\section{POGONOCHERUS CRINITUS LeConte}

Form elongate, eylindrical; integument tough, shining, sparsely clothed with rather sitff golden liairs.

Heal depressed, rather thick, sides not restricted behind, widest just behind anterior margin; mouth-frame darkly chitinized; labrum transversely oval, densely ciliate in front, posterior latlf more darkly coloured; mandible from side about one and one-half times as long as condylar width, cutting edge broadly emarginate, dorsal angle slightly toothed; one indistinct ocellus; antemual ring open behind. Ventral mouth-parts nearly glabrous; palpi darkly chitinized, maxillary three-jointed, apical joint conical, about equal to basal and to cylindrical last labial; mentum distinet, sunken; hypostoma very strongly protuberant posteriorly, anterior margin curved; gular line distinet.

Protergum subtrapezoidal, bearing a row of hairs on anterior margin: pronotum rectangular, posteriorly faintly marked with shallow striae; sternum hairy; eusternum triangular; metanotum snooth, shining; mesonotum tuberculate.

Abdomen strongly annulated; ampullae seven, protuberant, dorsal bearing three irregular rows of large confluent tubereles; epipleurum protuberant only on last segments, tubercle very clongate oval, no chitinous pits; spiracles quite sniall, orbicular, peritreme dark; a short conical chit inous spine on ninth tergum; anus trilobed.

[Deseribed from specimens Hopk. 14492a.]

This larva feeds in dead dry branches of Quercus. It excavates irregular mines deep in the wood, often in the centre of the branch, tightly packed with fine frass. The pupal cell is constructed deep in the wood, having a projection at right angles to it, extending almost to the surface. The work much resembles that of $P$. negundo, and the life cycle probably extends over more than a year. The material was collected by F. B. Herbert, Los Gatos, Cal.

This species will not run down to Pogonocherus in the preceding key of genera. It differs from the other species in the open antennal cavities, threejointel palpi, and protuberant hypostoma. Under the discussion of $P$. negundo it was stated the genus Pogonocherus is composed of two larval types, the mixtus type with two-jointed maxillary palpi and a carinate cercal plate, and the negundo type, resembling Ecyrus, having three-jointed palpi and a spinelike cereus. This species forms a third distinct type. These types represent deciledly better defined genera, from the larval characters, than such genera as Arhopalus, Calloides, and Cyllene.

\section{ROPALOPUS SANGUINICOLLIS Horn}

Form elongate sub-cylindrical, slightly depressed anteriorly; integument firm, shining, reticulated, sparsely beset with short eastaneous hairs.

Head trapezoidal, widest just behind middle; epistoma straight, thick; labrum thin, subtriangular, sparsely haired; mandibles slightly longer than basal width, distal half piceous, basal dark castaneous granulate; second joint of antennae longest, supplementayr minute; one distinct, black, protuberant ocellus; gena receding, glabrous except for a few scattered hairs; yentral mouth-parts somewhat coriaceous; palpifer process and subfossal spine wanting; palpi joints subequal in length. 
Prothorax about twiee as wide as long with a dull granulate spot on sides; pronotum anteriorly coarsely punctured, posteriorly coarsely striate to alutaceous; median suture faint; sternum alutaceous, shining, not differentiated into areas; legs four-jointed, including tarsus and somewhat longer than maxillary palpus.

Abdomen. Dorsal ampullae shining alutaceous, bounded by two lateral converging folds connected anteriorly by a transverse one; ventral divided in middle by a broad, shallow depression; pleural dises distinet on first four abdominal segments; spiracles narrowly oval.

[Deseribed from speeimens 15045s Dominion Entomological Branch.]

Mr. J. N. Knull called the writer's attention to this species breeding in the trunks of wild cherry (Prunus) near Bathurst, N.B. Many smaller trees up to two, three and four inches in diameter had been killed. The eggs are laid under scales of bark and the larvae mine extensively beneath the bark, killing areas from two inches wide to eight inches long. The mines are packed with granular frass. Later the larvae enter the wood like Romaleum rufulum, boring up the stem in the heartwood from six to twelve inches. At the upper end of this tumnel the pupal cell is made and the emergence hole is cut out at the same end. Large masses of gum on the trunks are characteristic of the attack. The life-cycle extends over two seasons.

\section{STEIROSTEMA DEPRESSUM Linnaeus}

Form elongate, subeylindrieal; integument thin, shining, very sparsely clothed with eoarse hairs.

Head depressed, sides not constricterl behind, anterior margin darkly chitinized and very finely granulate; labrum thin, transversely oval, widest at middle, anterior half densely hairy; mandible from side about twice as long as condylar width, cutting-edge emarginate, dorsal angle toothed; antennal ring open behind; one pair of ocelli. Ventral mouth-parts beset with coarse hairs; maxillary palpi slender, last joint shortest, truneate at tip, shorter than last labial; anterior edge of hypostoma eurved; gilla not distinet.

Prothorax widest behind; pronotum posteriorly beset with rather coarse, ereet, chitinous asperities, except for a large, full, eentral, finely rugose area, on whieh these asperities are very fine or absent, also bearing two longitudinal, glabrous, darker spots on the anterior part of this area; anteriorly the lateral angle bears a group of hairs, extending more sparsely across protergum. Metanotum, mesosternum, and metasternum tuberculate.

Abdomen. Seven ampullae bearing dorsally four irregular rows of large, glabrous, shining tubereles, ventrally two rows; epipleurum protuberant, tubercle broadly oval, bearing two setae and two chitinous pores; anus trilobed; spiracles large, nearly orbieular.

[Deseribed from speeimens in the Inited States National Museum collection labelled 11s9, from cocoanut trees (Cocos nucifera), surinam.] ampullac.

Steirostema seems to suggest Acanthoderes from characters of the head and

\section{TETROPS JUNCUNDA LeConte}

This larva in all essential charaeters resembles that of Tetraopes tetraophthalmus. It differs as follows: Form more slender, borly hairs short, few except on last segment, where they form a dense ring; hypostoma very faintly wrinkled; one distinct black ocellus; labrum transversely semicircular, about twiee as wide as long, anterior inargin fringed with short hairs. Pronotum posteriorly velvety pubescent, darkest on two median projecting patches, eusiermum bearing a few hairs along sides; metanotum tubereulate. Ampullae strongly projecting, seven dorsal ones bearing two transverse rows of prominent regular tubercles.

[Deseribed from speeimens Hopk. U. s. 10626.]

The author collected larvae of this species feeding in the stem of wild morning-glory (I pomoea sp.) in the vicinity of the District of Columbia. It does not enter the tubers, as has been reported, but feeds only in the long creepers above the ground. The work resembles that of some species of Oberea in that it hollows the stems, ejecting the frass through small holes. Eggs were found in small sears gnawed through the bark, and inserted deep in the stems. Matured larvae were found in septentber by A. B. Champlain and the writer, hence the life-history is completed in one year. Adults are found on the flowers of the host.

The fact that this larva resembles that of Tetraopes in all essential characters further corroborates the belief that these genera constitute a group quite distinct from Oberea. 


\section{TETROPIUM ip.}

Ifuh matler than cimmemopterum and differing from velutimum in having the caudal spines reprentutul hy very minute, scarcely visable blunt tubercles, separated at least three times ther hasil thickness; pronotum and ampullac more fincly vellured, that on the former, eovering two-thurls of the area, latrum only hairy in front.

11) wribed from sperimens No. 15044: Dominion Entomologieal Branch.]

The larvac feech in the outer bark of living spruce. The mines are very meamlering and tightly packed with dark brown granular frass. They were collected hy the atuthor at Gaspe Basin, Quebec, and one adult was reared. This larva is quite distinet from the other species and the adult is extremely smilll. 


\section{LITERATURE GITED}

(1) Aurivillius, Chr.

1912. Coleopterorum catalogus. Part 39. Cerambycidae; Cerambyeinae. Berlin.

(2) Boving, A. G.

1914. On the abdominal structure of eertain beetle larvae of the eampodeiform type, In Proe. Ent. Soc. Wash., v. 16, No. 2, p. 55-61, pl. 3-6, June.

(3) Brooks, F. E.

1914. Apple root borer (Saperda candida Fab). In U.S. Dept. Agr. Jour. Agr Researeh, v. 3, No. 2, p. 179-1s1, pl. 29-31. Nov. 16.

(4) Casey, T. L.

1912. Memoirs of the Coleoptera, v. 3, 386 pp. Laneaster, Pa.

(5) Chapuis, F. and Candeze, E.

1853. Catalogue des larves des coléoptères. In Mem. Soee. Roy. des Sei. Liège, v. 8 , p. $347-653,9$ pl.

(6) Craighead, F. C.

1915. Larvae of the Prioninae. U.S. Dept. Agr. Off. Soe. Rept. 107. 24 p., $8 \mathrm{pl}$. Washington.

(7) " 1916. The determination of the abdominal and thoraeie areas of the cerambycid larvae as based on a study of the museles. Proc. Ent. Soe. Wash., v. 18, No. 3, p. 129-146, pl. 6-9, November 27 .

(8) Crampton, G. C.

1909. A contribution to the comparative morphology of the thoracie selerites of insects. In Proe. Acad. Nat. Sci. Phila., v. 61, p. 3-54, pl. 1-4.

(9) Fabre, J. H. C

1915. The Hunting Wasps. Tr. by Alexander Teixeira de Mattos. 427 p. New York.

(10) Felt, E. P. and Joutel, L. H.

1904. Monograph of the genus Saperda. New York State Mus. Bul. 74 (Entomology 20). $86 \mathrm{p} ., 14 \mathrm{pl}$. Albany.

(11) Gahan, C. J.

1906. Fauna of British India. Coleoptera, v. 1 (Cerambyeidae), 329 pp. London.

(12) Ganglbauer, Ludwig

1881. Bestimmungs-Tabellen der europaischen coleopteren, VII, Cerambyeidae.

In Verhandl. Zool. Bot. Gesell, Wien, v. 31, p. 681-75s, 1 pl.

(13) Gemuinger, Max and Harold B. DE

1872-3. Catalogue Coleopterorum, v. 9 and 10. Monaehii.

(14) Hess, W. N.

1917. The ehordotonal organs and pleural dises of ceranbycid larvae. In. Ann. Ent. Soc. Amer., v. 10, No. 1, p. 63-74, pl. 4-7, Mareh.

(15) Норкiss, A. D.

1909. The genus Dendroctonus. U.S. Dept. Agr. Bur. Ent., Tech. Ser. 17, Pt. 1. 164 p., 8 pl. June 30.

(16) “ 1915. Preliminary classifieation of the superfanily Scolytoidea. U. S. Dept. Agri. Bur. Ent. Tech. ser. 17, Pt. II, p. 16.5-232, pì. 9-16. Jan.9.

(17) Jensen Hathup, A. C., and Henriksen, K.

1914. Biller III: Traebukke Danish Cerambycidae, 114 p., Copenhagen.

(18) Kincaid, Trevor.

1900. The metamorphoses of some Alaska Coleoptera. In Proe. Wash. Acad. Sci., v. 2, p. 367-38s, pl. 22-26. (see p. 376.)

(19) Lacordaire, J. T.

1869. Genera des Coléoptères, v. \$-9. Paris. 


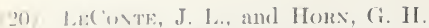

1sk3. C'lassifeation of the Coleoptera of North Aneriea. 576 p., Washington. (smithonian Mise. Coll., v. 26).

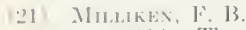

1916. The cottonwoulborer. U.S. Dept. Agr. Bul. 424, 7 p., 1 pl., 3 fig. November 9.

(2.) ():TT:X-SACKE: R

1s(i2. Description of some larvae of North American Coleoptera. In Proe. Ent. soc. Phila., v. 1, No. 5, p, 10.5-130. January.

(23) P'ACKARD, I. S

1s90. Fifth report of the $\mathrm{L}^{*} . \mathrm{S}$. Entomologieal Commission. [Being a revised and cnlarged edition of Bulletin No. 7 on Inseets injurious to forest and shade trees.] 955 p., 40. pl. Washington.

(24) P'Erris, Edouard.

14:56. Histoire des inseetes du pin maritime. In Ann. soe. Ent. Franee, ser. 3, v. 4, p. $423-4 \times 6$.

“ 1577. Larves des coléoptères. 590 p., 14 pl. Paris. Extrait de la Soe. Linn. de Lyon, v. 22, 1876.

(26) RathVoN, S. S.

1s61. Entomology and its relation to the vegetable produetiveness of the soil, with referenee to both destructive and benefieial inseets. In Rept. U. S. Com. Patents for 1861, p. 585-620. Washington.

(27) Riler, C. V.

1S90. Insects injurious to haekberry. In Fifth Report of the U. S. Ent. Com., p. 601-622. Washington.

Page 610-611; Description of Graphisurus triangulifer (Hald.).

(2s) " 1s92. Cerambycid larva in eotton stems (Oberea schaumii Lee.). In Proc. Ent. Soc. Wash., v. 2, p. 323-324.

(29) Ruggres, A. G. Life history of Oberea tripunctata Swed. In Jour. Econ. Ent., v. 8, 1915, No. 1, p. 79-85. February. (See p. 79.)

(30) Sichodte, J. M. C.

1863. Dinmarks cerambyces. In Naturhistotisk Tidsskrift, ser. 3, v. 2, p. 483-576, pl. 20. Translated in Ann. and Mag. Nat. Hist., ser. 3, v. 15, p. 182-209, 1865.

(31) " 1876-83. De metamorphosi eleutheratorum observationes, Part 9-12. From Naturhistorisk Tidsskrift, ser. 3, v. 10-13.

(32) Nixodgrass, R. E.

1909. The thorax of inseets and the artieulation of the wings. In Proc. I. S. Nat. Mus., v. 36, p. 511-595, pl. 40-69.

(33) TutT, J. W:

1895. An attempt to eorrelate the results arrived at in recent papers on the elassification of Lepidoptera. In Trans. Ent. Soe., London for 1895, p. 343-362.

(34) WЕBB, J. L.

1909. The southern pine sawyer (Monohammus titillator Fab.). U.S. Dept. Agr. Bur. Ent. Bul. 58, Pt. 4, p. 41-56, fig. 13-24. November, 10.

(35) " 1910. Injuries to forests and forest produets by roundheaded borers. In U. S. Dept. Agr. Yearbook for 1910, p. 341-358, fig. 19-29. 
INDEX TO SPEGIES, GENERA AND HIGHER GROUPS

abietis, Tetropium .

Acanthocinus

Acanthoderes.

Acanthoderes sp.

Acanthodides.

aceris, Xylotrechus.

Achryson.

Acmaeops

Acrocinus.

aculiferous, Leptostylus

acuminata, Strangalia.

Adetus..

aeneolus, Heterachthes

aereum, Callidium.... . .

albidus, Leptostylus.

albofasciatus, Clytoleptus.

alienum, Elaphidion.........

alpha, Liopus...

alternatum, Dorcaschema...

americana, Leptura...

amethystinus, Hylotrupes.

amoenus, Phymatodes.....

Anaglypti

andreae, Physocnemum...

Areflus.

annosus, $\mathrm{X}$ ylotrechus.

antennatum, Callidium

antennatus, Cyllene...

Anthophilax.

Apodasyides

araneiformis, Lagocheirus

Arhopalus

arizonense, Elaphidion...

armatum, Tragidion.....

Aseminae................

Asemum.

aspera, Leptura . .........

aspera, Nothorhina.

asperus, Hyperplatys.

Ataxia

Atimia .

atomarium, Romaleum

atrum, Asemum.

attenuatus, Anthophilax.

axillaris, Purpuricenus

bajulus, Hylotrupes.... .

batesi, Metaleptus.

Batyle. .

Bellamira

bicolor, Strangalia........

biforis, Leptura....... . .

bimaculata, Oberea.

bimaculatus, Molorehus.

bimaculatus, Tylonotus.

biustus, Leptostylus.

brevilineum, Physocnemum

Brothylus.

brunnea, Parandra.........

caeruleus, Encylops.

calcarata, Saperda

californicus, Pogonocherus

californicus, Prionus.......

Callichroma ..............

Callidiini.................

Callidium ...............

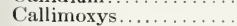

Calloides

canadensis, Leptura.

candida, Saperda

capraea, Neoclytus.

caryae, Cyllene pictus.

cavipennis, Necydalis

Centrodera.

Cerambycinae

Ceratographus.
Ceratographus sp.

Chion.

chrysocoma, Leptura

cinctus, Chion.

cincrea, Hetoem is

cingulata, Oneideres..

cinnamopterum, Tetropium

Clytanthus.

Clytini.

Clytoleptus

Clytus.

collaris, Gonocallus.

collaris, Leptostylus.

colonus, Xylotrechu:

concolor, Achryson

concolor, Saperda.

confusa, Atimia

confusor, Monochamus.

conicola, Paratimia.

conjunctus, Neoclytus.

convergens, Xylotrechus.

coquus, Tragidion.

cordifer, Neoclytus.

cortiphagus, Romaleum

costata, Oeme

crassipes, Leptura

cribripennis, Desmoeerus

crinitus, Pogonocherus

Criocephalus.

Crossidius.

crypta, Ataxia

cucujiforme, Smodicum

Curiini.

Curius.

cyanipennis, Gaurotes.

Cyllene.

Cyllenes..... .

Cyrtinus...

Cyrtophorus.

dasyecrus, Eeyrus

debilis, Goes

decipiens, Acanthoderes

decolorata, C'entrodera.

Dectes.

decussatus, Phymatodes.

Dendrobias.

dentatus, Curius.

depressum, Steirostem:

Derobrachus. .

Desmocerus.

dimidiatus, Phymatodes

directa, Acinaeops.

discoidlea, Sapercla

Distenia.

Disteniinae

Dorcaschema.

dorsalis, Atimia

Dysphaga.

ebenus, Heteracht lies.

Eburia

Eburia sp.

Eburiini

Eeyrus

Elaphidion.

Elaphiclion sp. 9901q and 9903s

Elaphirlion sp. 10055

Elaphidion sp. 10500a

Elaphiclion sp. 10961d

Elaphidion sp. 12283i. .

Elaphiclion sp. 122831.

Elaphidion spp.

emarginata, Leptura.

emarginata, Homaesthesis.

Encyclops.

Ergates.

PAGE

122 
cry hrocephulus, Neoclytus.

liurrossus.

Euclereses

Ėupogonius

Fust rom:

exclamationis, Ibiclion.

exigua, Ieptura

famelica, st rungalia

faseiatus, Graphisurus.

ferruginea, Oberea.

flavipes, Oberea

frigidum, Callidium.

fuluinans, Arhopalus

fulvipenne. Tragidion.

fuseipennis, ('allimoxys

Gaurotes.

gazellula, Mieroelytus

geminata, Tillomorpha

genmulatus, Brothylus.

Goes

Gonoeallus.

Graphisurus.

guexi, Synaphoeta.

haldemani, Nyssodrys.

Haplidus

harisii, Trugosoma

hebes, Graphisuru.

Heterachthes

heterodoxum, Michthysoma

Heterospini.

Hetoemis.

Hipposini.

Hippopsis

hirtellum, Callidium

hoff mani, Anthophilax.

Homasthesis.

Hoplosia

hornii, Saperda

humeralis, Purpurieenus

Hylotrupes.

Hyperplatys..........

Ibidion

Ibidionini.

Idoemea

Idoemea sp.

ignicollis, Batyle.

imbrieornis, Prionus.

imitans, Saperda.

ineertum, Elaphidion.

inerme, Elaphidion

insignis, Xylotreehus .

integer, Homaesthesis

jucunda, Tetrops.

juniperus, Hylotrupes.

laevieollis, Necydalis

Lagoeheirus.

Lamiinae.

lateralis, Saperda

lemniseata, Hippopsis.

leoninus, Ulochaetes.

Leptalia.

Leptostylus. . . .

Leptura.

Lepturges.

Lepturges querei (group)

Lepturinae.

ligneus, Hylotrupes.

lineatum, Rhagium.

lineatus, Malaeopterus.

lineola, Leptura

Liopus

longimanus, Aeroeinus.

longipes, Neoelytus.

longipes, Rhopalophora

lunatus, Typocerus.

luscus, Neoelytus.

luteieornis, Stranoalia..
PAGE
Malacopterus

Mallodon.

maeilenta, Leptalia................... 89

macula, leptost ylus................... 115

maculatum, Olorium (Phyton pallidum)... 62

maculosus, Monochamus.................. 107

mandibularis, Dendrobias.............. 81

marginieollis, Clytus................. 55

marmorator, Monochamus............. 107

Mecas............. 138

mellitus, Nceydalis.................... 84

Merium................... 48

Metaleptus........................ 80

Methia

Methini............. 38

Miehtlysoma ...................... 103

M ieroelvtus....................... 60

mixtus, Pogonoeherus................. 122

moesta, Saperda. . . . . . . . . . . . . . . . 129

moestum, Asemum ................... 31

Molorehini. .............................. 60

Molorehus,......................... 62

Monilema .......................... 103

Monoehamides ..................... 105

Monoehamus. ....................... 105

montanus, Crioeephalus.................. 33

montieola, Paehyta...................... 141

morrisii, Aeanthoderes.................... 113

mueronatum, Elaphidion .................. 69

murieatulus, Neoelytus.................. 55

mutabilis, Leptura 98

mutiea or ovieollis, Eubria ............. $6 i$

myops, Oberea....................... 141

nautieus, Xylotreehus................. $\quad 57$

nebulosus, Leptostylus..................... 115

Neeydalini.

Neeydalis. 83

negundo, Pogonoeherus. . . . . . . . . ........ 123

Neoelytus ......................... 53

nigrella, Leptura ..................... 95

nigrum, Doreaschema............... $\quad 110$

nitens, Leptura. . . . . . . . 99

nitidum, Asemum.... _............. 32

nitidus, Phymatodes..................... 45

nobilis, Calloides......... 51

nodosus, Aeanthoeinus................. 119

notatus, Stenosphenus .................. 72

Nothorhina...................... 31

nubilia Hoplosia...................... 125

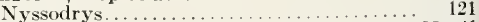

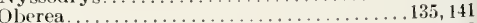

obliqua, Saperda . . . . . . . . . . . . . . . 129

obliquus, Aeanthocinus................. 120

obliterata, Leptura .................... 95

obliteratus, Xylotreehus............... $\quad 58$

Obrium........................ $\quad 62$

obsoletus, Aeanthosinus................ $\quad \begin{array}{r}120 \\ 33\end{array}$

obsoletus, Crioeephalus................. $\begin{array}{r}33 \\ 137\end{array}$

oeellata, Oberea..................... 109

Oeme

Oemini............................. 38

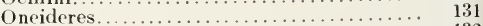

Oneideres sp...................... ${ }_{5} 32$

Opsimus........................... 35

Orthosoma ....................... $\quad 27$

ovicollis or mutiea, Eburia ............ 67

Paehyta.......................... 88,141

palliatus, Desmocerus................. 87

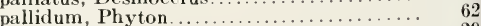

Parandra........................... $\quad 29$

Paratimia ......................... $\begin{array}{r}35 \\ 116\end{array}$

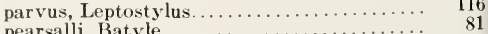

pearsalli, Batyle.......................... ${ }_{123}$

pergrata, Mecas ........................ 138

Phoraeanthini................................ 67 
INDEX TO SPECIES, GENERA AND HIGHER GROLPS-Concluded

Phymatodes

Physocnemum

Phytoceides.

Phyton

picipes, Euderces

pictus. Cyllene

pini, Leptostylus

piperi, Desmocerus......

plagifera, Leptura.

Plagionotus.

Plectrodera...

Plectrura

plicatum, Callichroma........

Pogonocherus.

Pogonocherus sp.

Prioninae

Prionus..

productus, Criocephalus.

propinqua, Leptura

protensus, Aneflus.

proteus, Merium.

proxima, Leptura

Psenocerus

Ptychodes.

pulchellus, Crossidius

pulcher, Goes

pulverulentus, Goes

punctatus, Liopus.

puncticollis. Saperda

Purpuricenus...

pusilla, Methia

putator, Oncideres.

pygmaeus, Cyrtinus

quadrigeminata, Eburia

quadrigibbus, Acanthoderes.

quadrilineatus, Opsimus

quadrimaculatus, Heterachthes

quadrimaculatus, Xylotrechus

querei, Lepturges.

querci, Lepturges (group)...

Rhagium

Rhopalophora

Rhopalophorin

Rhopalopus

rigida, Oeme

robiniae, Cyllene

Romaleum.

Romaleum sp. 11si1

rubrica, Leptura

rubrum, Obrium. See rufulum, Obrium.

ruficollis, Oberea.

rufulum Gahan (rubrum Newman), Obrium.

rufulum Haldemann, Romaleum.

rugiscopis, Distenia

ruricola, Clytanthus

sagit tatus. Xylotrechus

salicola, Pogonocherus.

sanguinea, Leptura....

Saperda

scalaris, Bellamira

scalator, Plectrodera

schaumii. Oberea

scutellaris, Jeoclytus.

scutellatus, Monochamus.

senas, Shizas

sexguttatus, Leptostvlus

Shizax.

signatus, Lepturges

smodicum......

soror, Leptura. .

Spalacopsis.

speciosus, Plagionotus....

spectabilis, Acanthocinus.
P.AGE spermophagus, Lepturges

sphenostethus.

sphaericollis, Leptura.

spinicauda, Plectrura

spinosus, Dectes.

spondylis.

Steirostema.

Stenaspini.

Stenodontes.

Stenosphenus

-tenosphenus sp. 10356

stolata, Spalacopsis...

strangalia.

strangulata, Oeme

subellipticus, Adetus

subhamata, Leptura.

subpubescens. Elaphidion.

sulcata, Ataxia.

supernotatus, Psenocerus

surinamum, Achryson.

suturalis. Batyle.

symmetricus, Lepturges

Synaphoeta.

taslei, - iphenostethus

tenebrosus Anthophilax

tenue, Elaphidion.

tenuipes. Dyshpaga

terraecolor, Leptostylus

tesselatus, Goes

testaceous, Haplidus.

Tetraopes

tetraophthalmus. Tetraopes

Tetropium

Tetrops.

tigrinus, Goes

Tillomorpha.

titillator. Monochamus

tomentosus. Eupogonius. . .

townsendi, Ibidion.

Toxotus.

Tragidion

Tragosoma

triangulifer, Graphisurus

tridentata, saperda.

trilineatus. Ptychodes

tripunctata, Oberea .

Tylonotus.

Typocerus

Tlochaetes

undata, Distenia

undulatus. Xylotrechus.

unicolor, Elaphidion

vagans, Leptura

valida. Leptura. .

validum, Eustroma

variabilis. Phymatodes.

variegetus, Liopus

varius. Phymatodes.

velutinum. Tetropium

velutinus, Typocerus

verrucosus, Cyrtophorus

vestita, saperda.

vestitus, Eupogonius

villicornus. Eucrossus . .

villosum, Elaphidion

viridis. Anthophilax.

vit tata. Leptura...

vulneratus. Phyma todes.

wildii, Doreaschema

Xylotrechus.

Xylotrechus sp. 10359

Xylocrius?

zebratus, $\mathrm{T}$ ypocerus
PAGE

119 


\section{ABIBREVIATIONS USED IN PLATES AND TEXT FIGURES}

I.1. first abdominal segment.

II.i. second ablominal segment.

III A, third ablominal segment.

$1,2,3$, first, second and third joints of antennae.

$a$, iljex of mandible.

an, anterior area of pronotum.

1.1, alar areas.

ai, anal spine.

al, anal lobes.

am, basal articulating membrane of antennae.

A $m b$. $A m p$, ambulatory ampullae.

ant, antennae.

ar, antennal rings or annuli.

as, alar spots or plates.

asrm, attachment of superior retractor museles of head.

c, cardo.

ci, caudal spines or eerci.

cly, elypeus.

co, eollar, or skin conncetion between protl orax and head.

$c p$, chitinous pits of pleura! tuberste.

$c u$, cuneus.

$c x$, coxa.

Cxl, eoxal lobe.

$d$, pleural dises.

$d s$, dorsal angle of eutting-edge of mandible.

$d l$, dorso-lateral suture.

$e p$, epistoma.

epic, epieranium.

eps, epistomal setae.

$e s$, eusternal spots or plates.

Est, eusternum.

$F$, front.

$f$, femur

frs, frontal suture of head.

$g$, gena.

$g s$, genal setae.

$g u$, gula.

$H p$, hypopleurum.

$h s$, hypostomal suture.

$h y$, hypostoma.

Inseg, intersegmental skin.

$l$, lateral suture of pronotum.

$l a b$, labrum.

lac, laeinia.

$l i$, ligula.

$l p$, labial palpi.

lpal, labial palpifer.

$l s$, lateral spots or plates.

$L_{2}$, epipleurum.

$M$, median suture of head.

$m$, mentum. $m a$, median area of pronotum.

$m d$, mandible.

Mesn, mesonotum.

$m$ palf, inaxillary palpifer.

$m s$, median pronotal suture.

Ms T, mesothorax.

Mt $T$, metathorax.

$m x p$, maxillary palpus.

mxsc, maxillary sclerite.

$N$, notum.

$n s$, notal spots or plates.

$o$, ocelli.

occ. for, oecipital foramen.

$p$, palpifer.

$P A$, proalar area.

$p a$, posterior area of pronotum.

PaSc, paraseutal area.

pcca, postcondylar carina

$P l$, pleural lobe or tubercle.

$P n$, pronotum.

$P n F$, postnotal fold.

po, pleurostoma.

$p p$, proeess of palpifer.

PrSt, presternum.

$\operatorname{Pr} T$, prothorax.

$\mathrm{PrTg}$, protergum.

$p s$, presternal spots or plates.

$P S c$, prescutum.

$S$, sternum

$s$, spiracle.

$s a$, skin attachment of ventral mouthparts to prothorax.

Sc, seutum.

Scl, scutellum.

$s e$, spiraeular ellipse.

$s f s p$, subfossal spine or process.

$s j$, supplementary joint of antennae.

$S l$, sternellum.

$s m$, submentum.

$s p$, scutal plate.

Sp A, spiracular area.

st, maxillary stipes.

Sill, sternellum.

$T$, tergum.

$t$, tarsus.

$t a$, tentorial arm.

$t b$, tentorial bridge.

$t i$, tibia.

$t p$, tentorial pits.

$t r$, trochanter.

$v l$, ventro-lateral suture.

vrm, attachment of ventral retractor muscles of head. 
EXPLANATION OF PLATES 


\section{PLATE I}

\section{Mandibles of Larvae of Cerambycidae}

Fig. 1.-Leptalia macilenta.

FIG. 2.-Eneyclops caeruleus.

Fig. 3.-Pachyta monticola.

FIG. 4.-Rhagium lineatum.

Fig. 5.-Bellamira scalaris.

Fig. 6.-Romaleum rufulum.

Fig. 7.-Neoclytus capraea.

Fig. 8.-Metaleptus batesi.

Fig. 9.-Spondylis buprestoides (from Perris, Insectes du Pin Maritime).

FIG. 10.-Homaesthesis emarginatus.

FIG. 11.-Elaphidion subpubescens. 
PLATE NO. I

6
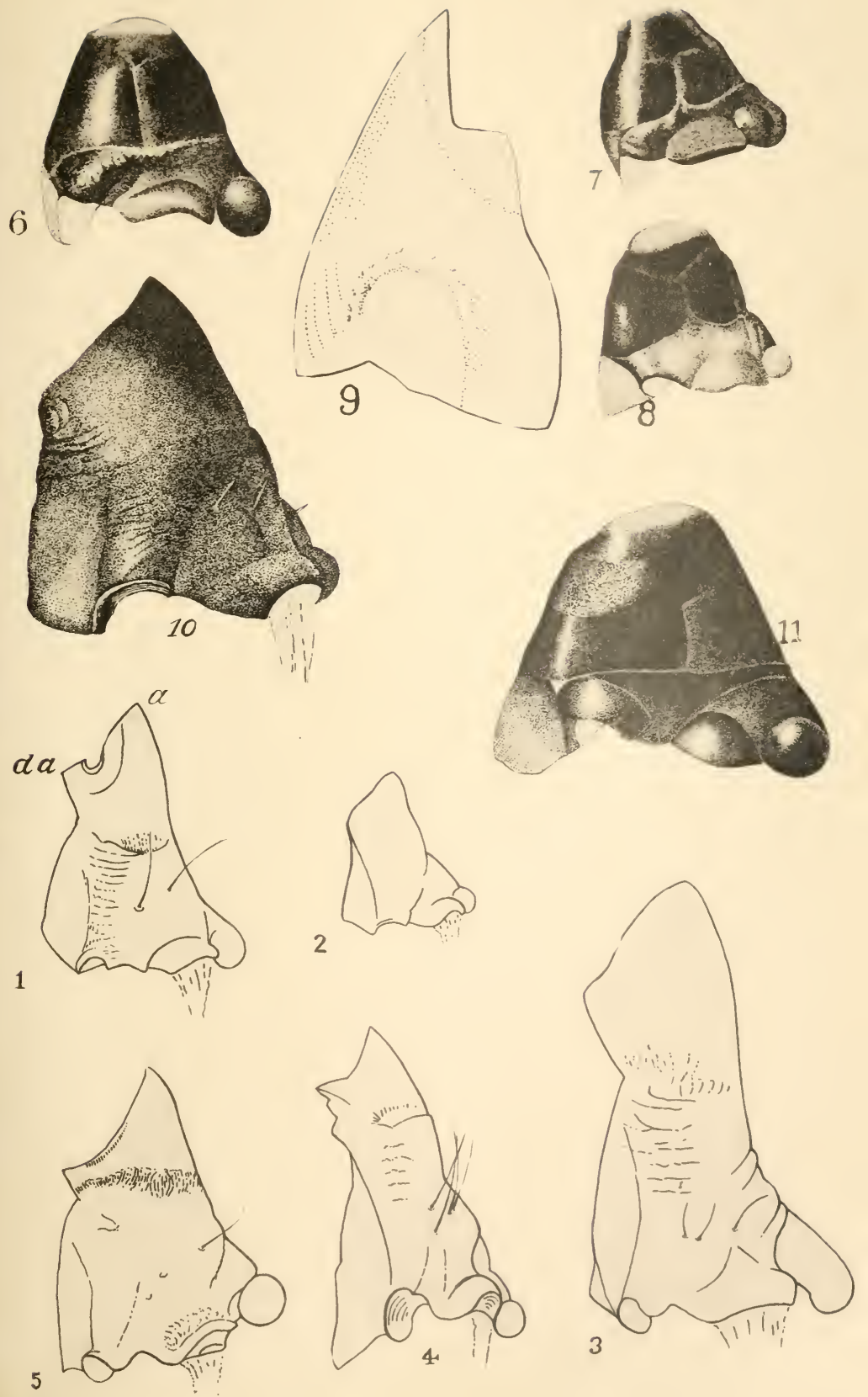




\section{PLATE II}

\section{Maxdibles of LaRYaE of Asemixae aNd Laminae}

Fig. 1.-Tetropium cinnamopterum: Outer face of right mandible.

FIg. 2.-Tetropium cinnamopterum: Inner face of right mandible. Note the less produced apex and rounded dorsal angle.

FIg. 3.-Opsimus quadrilineatus: Outer face of right mandible. Note the rounded, gouge-like cutting edge.

Frg. 4.-Asemum nitidum: Outer face of right mandible. Note the produced apex and flattened dorsal angle.

FIG. 5.-Asemum nitidum: Inner face of right mandible.

Fig.6.-Criocephalus productus: Outer face of right mandible. Similar to Asemum, except that the striated plate is more strongly engraved.

FIG. 7.-Criocephalus productus: Inner face of right mandible.

FIG. 8.-Adetus subellipticus: Outer face of right mandible.

FIG. 9.-Oncideres cingulata: Outer face of right mandible.

Fig. 10.-Oberea ruficollis: Outer face of right mandible.

FIG, 11.-Goes tigrinus: Outer face of right mandible.

FIG. 12.-Michthysoma heterodoxum, showing tooth that is absent in some forms.

Fig. 13.-Hippopsis lemniscata: Outer face of right mandible. 
PLATE NO. II.
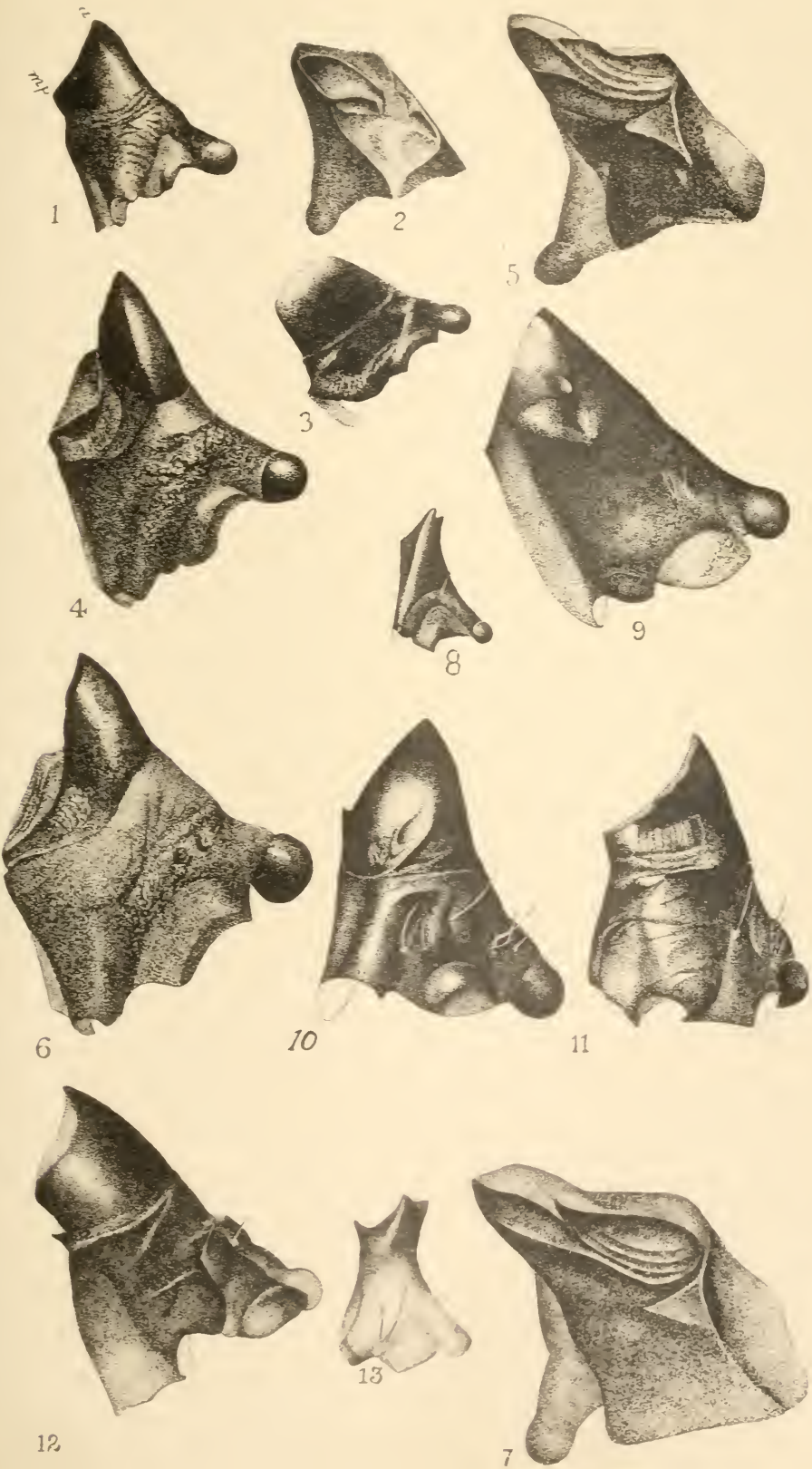




\section{Larvae of Cerambycidae}

FIG. 1.-C'rioce phalus productus: Lateral view of two abdominal segments showing typical structure. Figs. 2, 3.-Spondylis buprestoides: antennae and labrum (from Perris, Insectes du Pin Maritime). Fig. 4.-Atimia dorsalis: Labrum.

Fig. 5.-Asemum atrum: Labrum.

Fig. 6.-Tctropium abietis: Labrum.

FIG. 7.-Asemum nitidum: Labrum.

FIG. 8.-C'rioeephalus produetus: Labrum.

FIg. 9.-Leptura sphaericollis: Labrum. 
PLATE No. III.

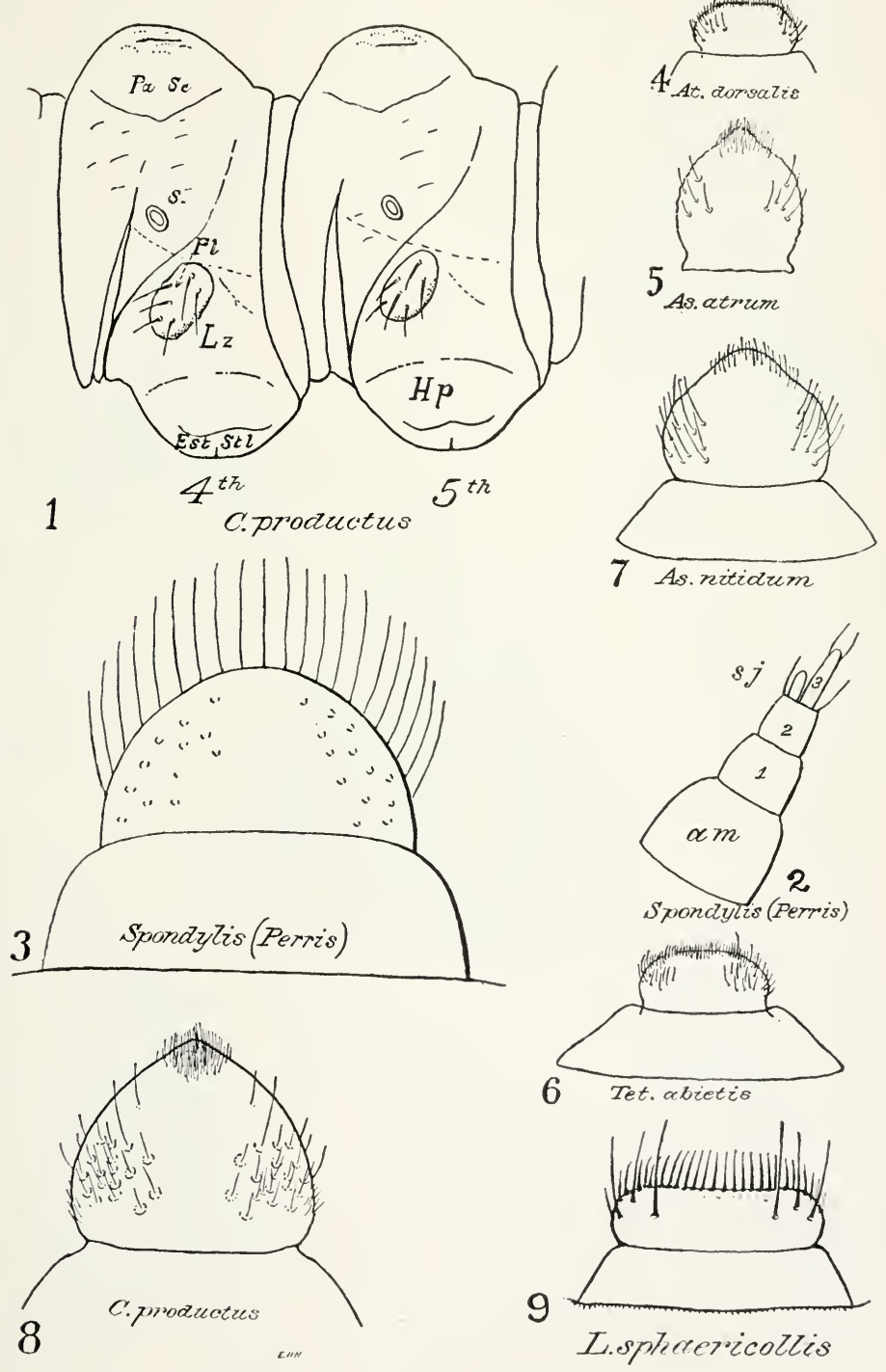




\section{PLATE IV}

\section{Mandibles of Larvae of Lepturinae and of a Distenine}

FIG. 1.-Gaurotes eyanipennis.

Fig. 2.-Leptura obliterata. Note the dorsal angle flattened into a striated plate.

FIG. 3.-Clochactes leoninus. Note the deep, oblique suleus on the apical portion.

Fig. 4.-Leptura proxima.

FIG. 5.-Distenia undata. The parallel edges of the outer face and the short cutting edge of this mandible suggest the lamiine type. 
PLATE NO. IV.

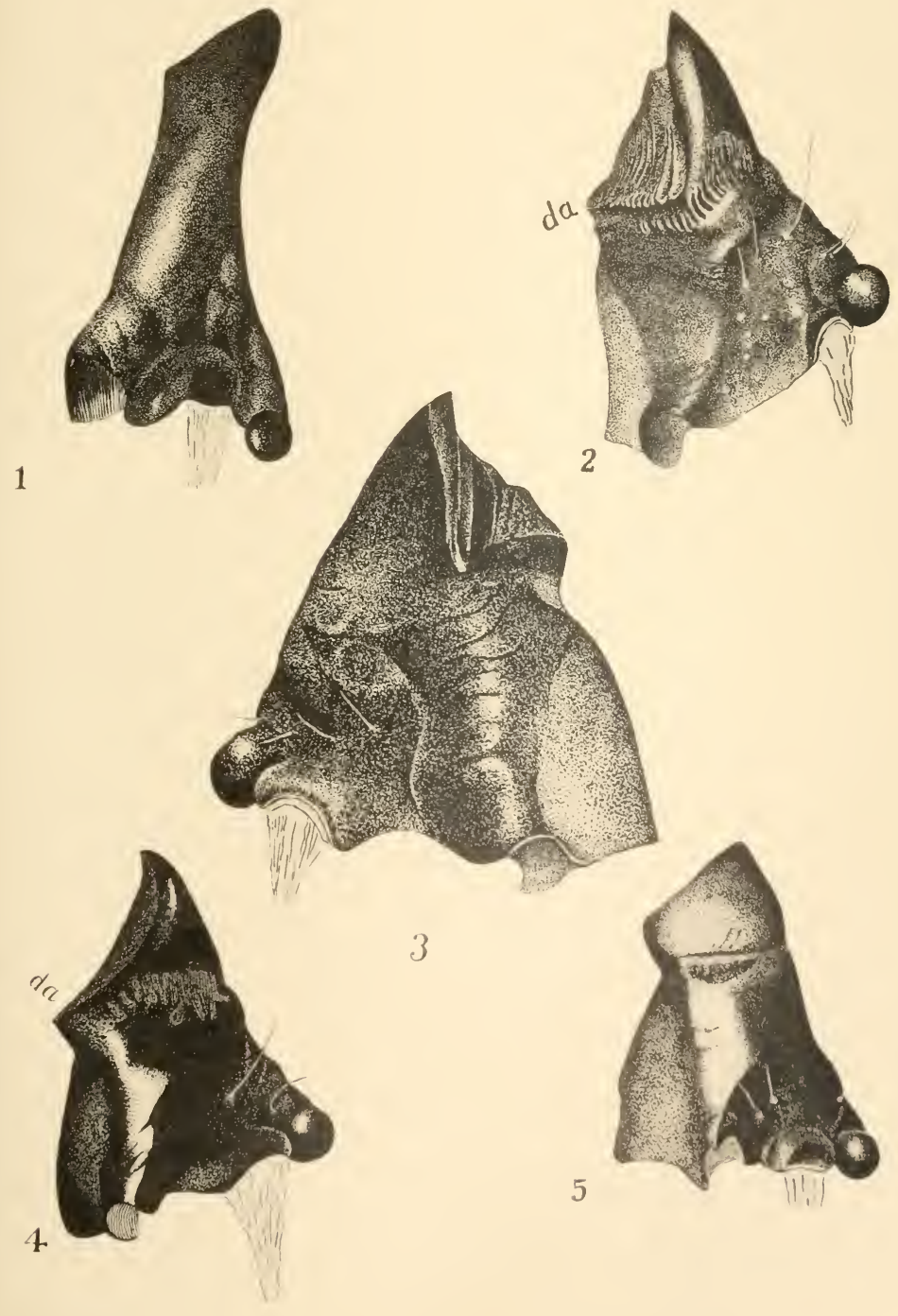






\section{PLATE V}

\section{Mandibles of Larvae of Laminae}

[Note the upper angle of the cutting edge and the texture of the outer face.)

Fig. 1.-Hetoemis cinerea.

Fig. 2.-Wichthysoma heterodoxum.

FIG. 3.-Eupogonius tomentosus.

FIG. 4.-Tetraopes tetraophthalmus.

Fig. 5.-Ptychodes trilineatus.

Fig. 6.-Ataxia crypta.

Fig. 7.-Dectes spinosus.

Fig. 8.-Goes oculatus.

Fig. 9.-Ecyrus dasycerus. 
PLATE NO. V.
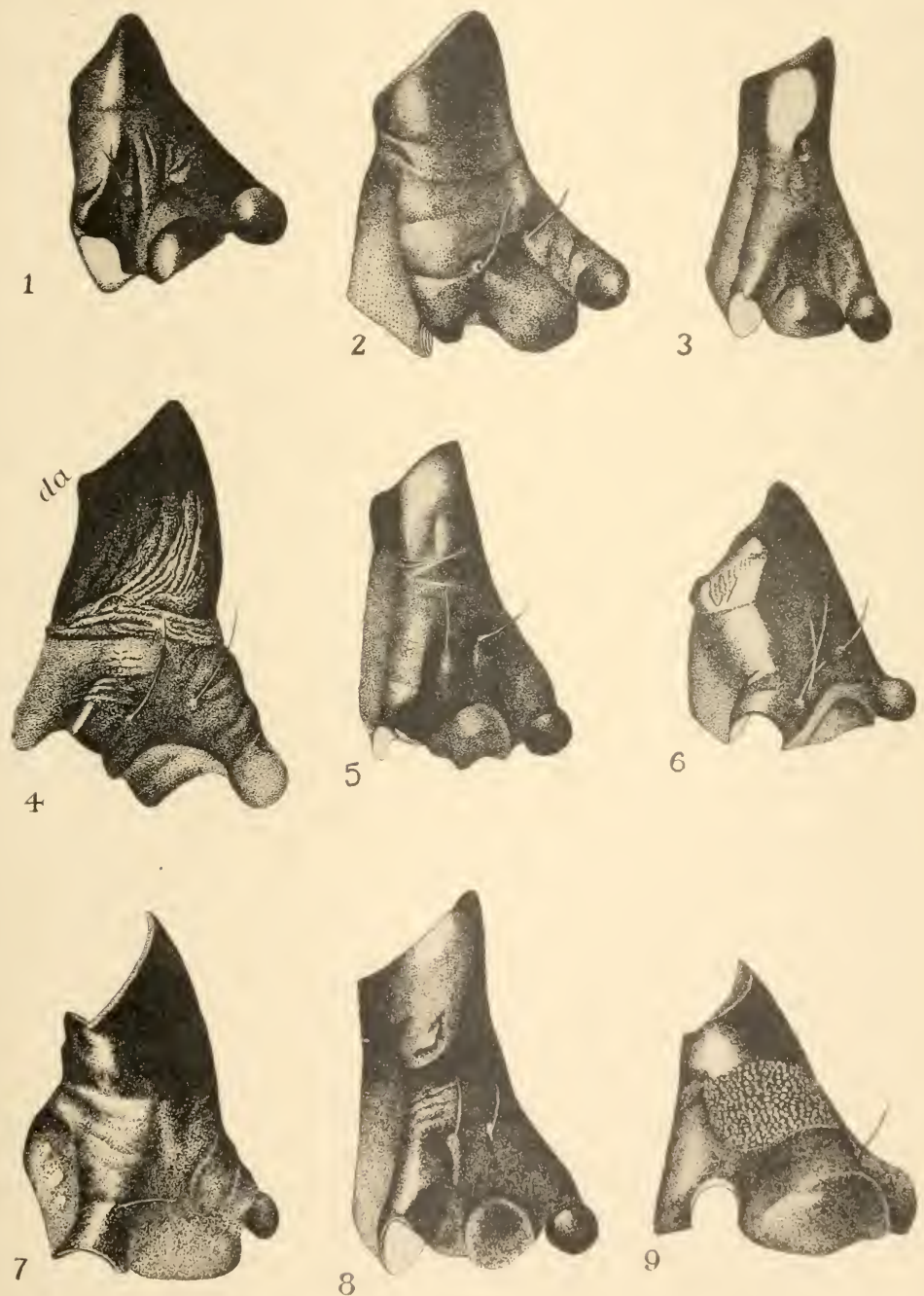



\section{PLATE VI}

\section{Cerci of Larvaf of Aseminae}

Fic, 1. - 1 sf mum atrum: Cerci or caudal spines, from behind.

Fig. 2-1timia dorsalis: Cerei from behind.

Fig, 3. C'riocephalus productus: Cerci from side.

FIG. 4.-1semum nitidum: Cerci from behind.

FIG. 5.-Tetropium velutinum: Cerci from behind.

Fig. 6.-Criocephalus productus: Cerei from behind.

Fig. 7.-Paratimia conicola: Cerei from behind.

FIG. 8.- Asemum moestum: Cerci from behind.

FIG. 9.-Tetropium cinnamopterum: Cerci from behind.

Fig, 10.- Nothorhina aspera: Cerei from behind.

FIG. 11.-Sipondylis buprestoides: Cerci from above. (Perris.)

FIG. 12.-1semum moestum: Lateral view of last three abdominal segments. 
PLATE No. V1.
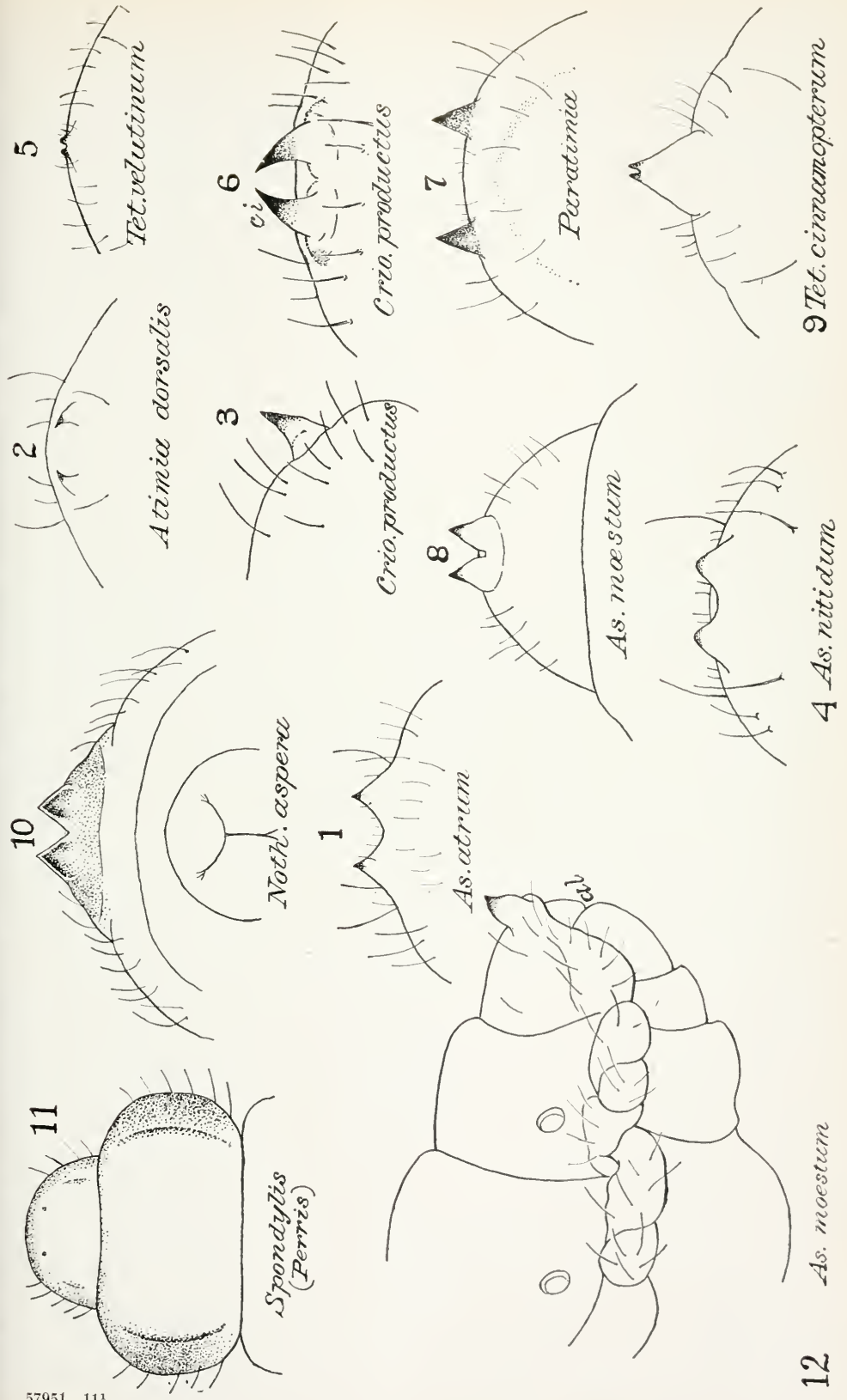

$57951-11 \frac{1}{2}$
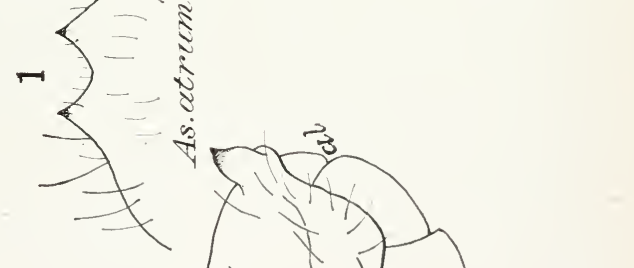


\section{PLATE VII}

\section{Last Segment of Larvae of Laminae}

Fig. 1.-Pogonocherus mixtus: Last segment from side.

FIG. 2.-Pogonocherus mixtus: Last segment from above.

Fig. 3.-Graphisurus fasciatus: Last segment from side.

Fig. 4.-Graphisurus fasciatus: Last segment from above.

Fig. 5.-Lepturges symmetricus: Last segment from side.

FIG. 6.-Plectrura spinicauda: Last segment from above.

FIG. 7.-Plectrura spinicauda: Last segment from side.

FIG. 8.-Pogonocherus salicola: Last segment from above.

FIG. 9.-Dorcaschema wildii: Last segment from side.

FIG. 10.-Michthysoma heterodoxum: Last segment from behind.

Fic. 11.-Hippopsis lemniscata: Last segment from side.

FIG. 12.-Monochamus titillator: Last segment from side.

Fic. 13.- Adetus subellipticus: Last segment from side.

Fig. 14.-Ataxia crypta: Last segment from side.

Fig. 15.-Ptychodes trilineatus: Last segment from side.

FIG. 16.-S palacopsis stolata: Last segment from side. 

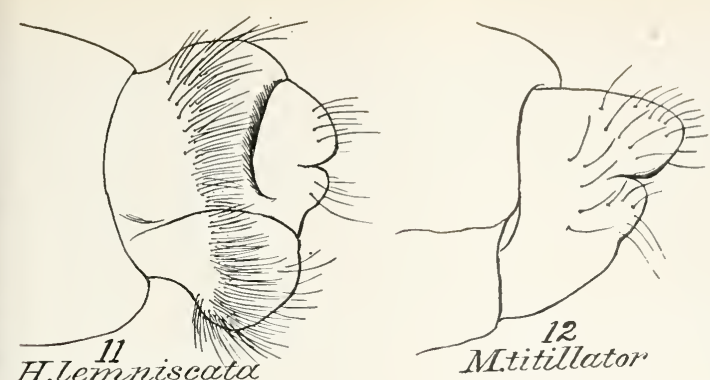

PIATE No. VII.

(Pspinicauda)

H.Zemniscoto

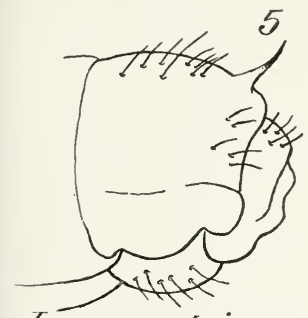

L.symmetricus
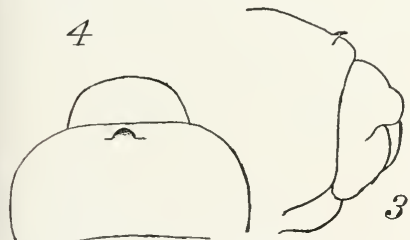

Graphisurus $f$.

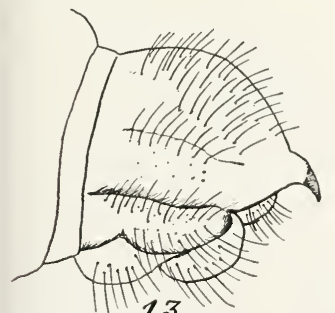

$$
13
$$

Ad.subellipticus

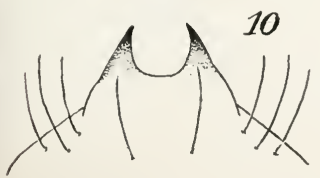

Mich.heterodoxum
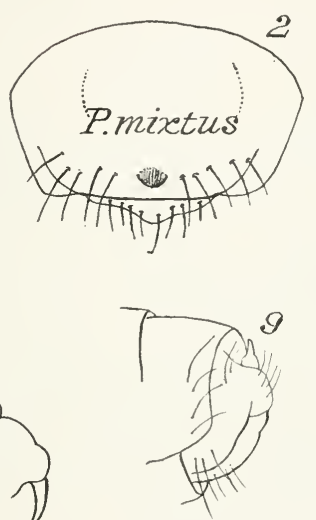

D.wildii

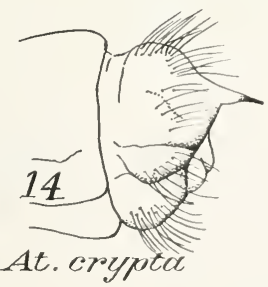

At. crypta

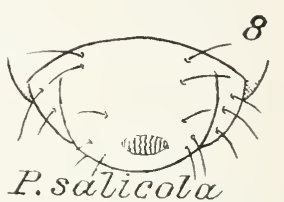

P.spinicauda
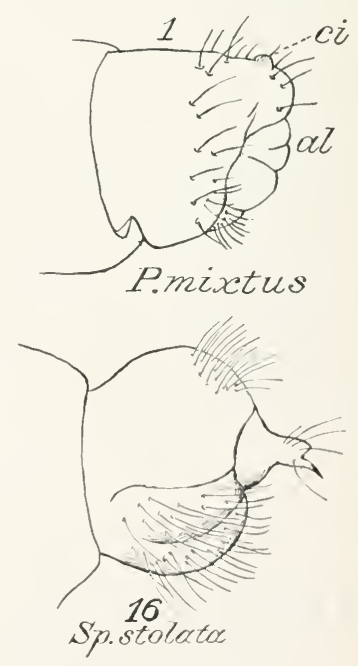

$$
\text { (1) }
$$

6)ोin

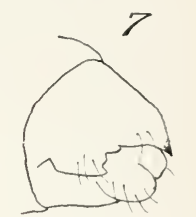

(n)




\section{PLATE VIII}

\section{Motthparts of LaRvae of Cerambycinae}

Fic. 1.-Oeme rigida: Ventral view of head.

Fic. 2.-Dys phaga tenuipes: Ventral view of head.

FIG. 3.-Euderes picipes: lentral view of mouthparts.

Fiti, 4. Methia pusilla: Ventral view of mouthparts.

Fig. 5.- Alimia dorsalis: Dorsal view of head.

Fig. 6.-Opsimus quadritineatus: Ventral mouthparts, showing large palpifer, 2-jointed maxillary palpus, and lanceolate lacinia. Note the gula, not distinct.

FIG. 7.-Tetropium abieis: Ventral mouthparts. Note the short gula.

FIG. 8.- Asemum nitidum: Ventral view of head. Note the long gula.

Fig. 9.-Elaphidion mucronatum: Epistoma and setae.

FIG. 10.-Elaphidion 10961d: Epistoma and setae.

FIG. 11.-Elaphidion inerme: Epistoma and setae.

FIG. 12,-Elaphidion unicolor: Hypostoma and gula.

Fig. 13.-Romaleum rufulum: Ventral view of head.

Fig. 14.-Chion cinctus: Ventral view of head. 

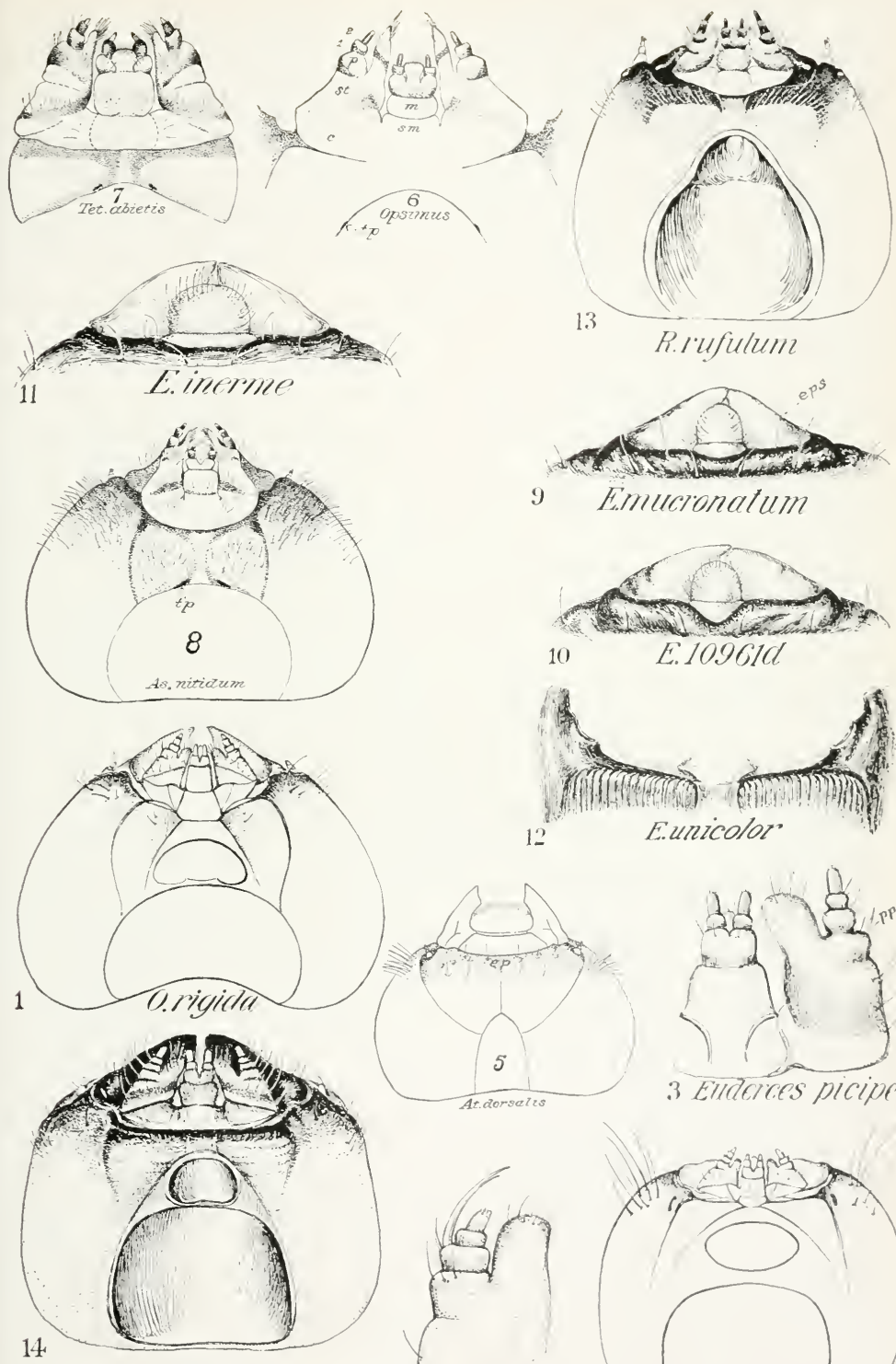

Chion cinclus

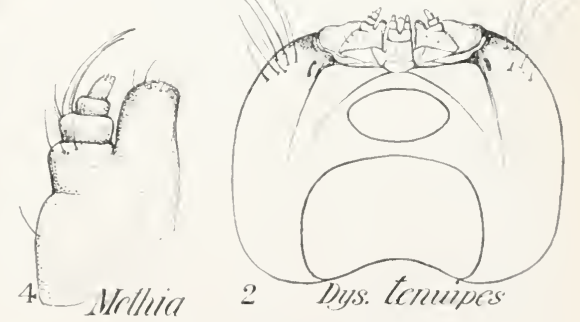




\section{PLATE IX}

Mouthparts of Larvae of Cerambycinae

FIG. 1.-Phymatodes amoenus: Ventral mouthparts.

Fig. 2.-Cyrtophon us verrucosus: Ventral mouthparts.

FIG. 3.-Curius dentatus: Ventral view of head.

FIG. 4.-Molorchus bimaculatus: Ventral view of head.

FIG. 5.-C'allichroma plicatum: Ventral view of head.

FIg. 6.-Haplidus testaceus: Ventral view of head.

Fig. 7.-Tylonotus bimaculatus: Dorsal view of head.

Fig. 8.-Callichroma plicatum: Dorsal view of head. 


\section{Plate X}

\section{Mottil-Frame of Larvae of Cerambicivae}

[View from in front, showing the position of ocellus with relation to the antennae, the shouldered or tapering gena, and the setae.]

Fig. 1.-Metaleptus batesi.

FIG. 2.-Romaleum atomarium.

Fig. 3.-Elaphidion tcnue.

Fig. 4.-Cyrtophorus verrucosus.

Fig. 5.-Caliidium antennatum.

FIG. 6.-Elaphidion mucronatum.

FIG. 7.-Gonocallus collaris.

Fig. 8.-Hylotrupes amethystinus.

Fig. 9.-Neoclytus capraea.

FIg. 10.-Calloides nobilis. 

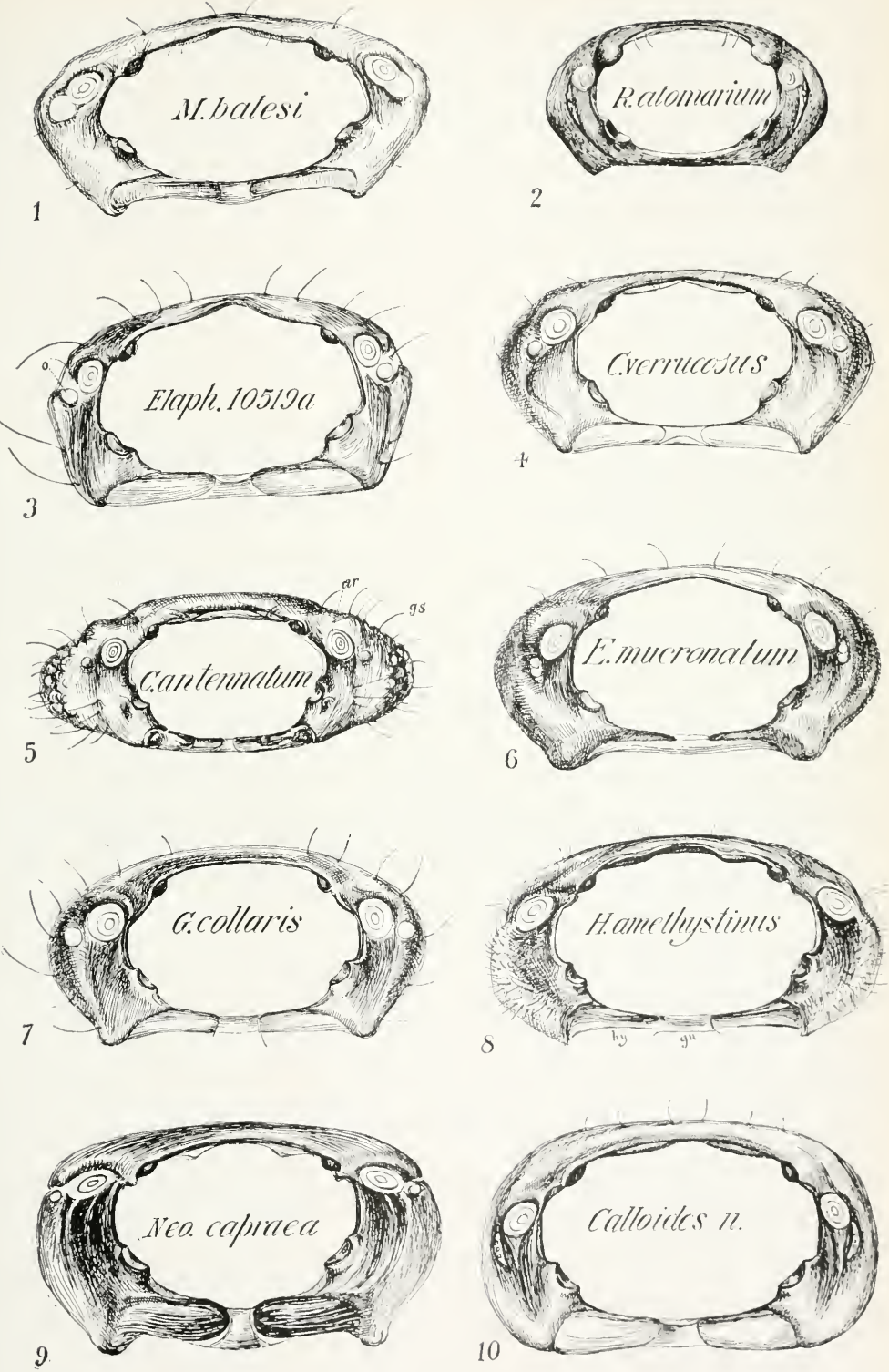


\section{PLATE XI}

Head of Larvae of Lepterinae and of a Distenine

Ftg. 1.- Necydalis cavipennis: Dorsal view of head. Note the prominent, dorsally placed antennae.

FIG. 2.- Vecydalis cavipennis: Ventral view of head. Note that the dorsal margins of the epicranium are not entirely emarginate behind the front, as in figure 4. Note also the large lacinia.

Fig, 3.-Rhagium lineatum: Ventral view of head.

FIG. 4.-Rhagium lineatum: Dorsal view of head. Note attachment of inferior retractor muscles of head and compare with Distenia. Also note that Rhagium has many epistomal setae instead of the usual number.

FIG. 5.-Centrodera decolorata: Ventral view of head, showing wide, prominent gula.

FIG. 6.-Leptura nitens: Ventral view of head with tentorial structures diagrammatically illustrated; these extend dorsally to the front of the head.

FIG. 7.-Distenia undata: Ventral view of head to show the structure. Note that the skin of the prothorax extends over the entire ventral surface of the head and is attached to the base of the submentum. The gula and hypostoma are not developed and the ventral brilge of the head capsule consists of the expanded tentorial bridge.

FIG. 8.-Anthophilax sp. 9790l: Dorsal view of head to show division of front. 

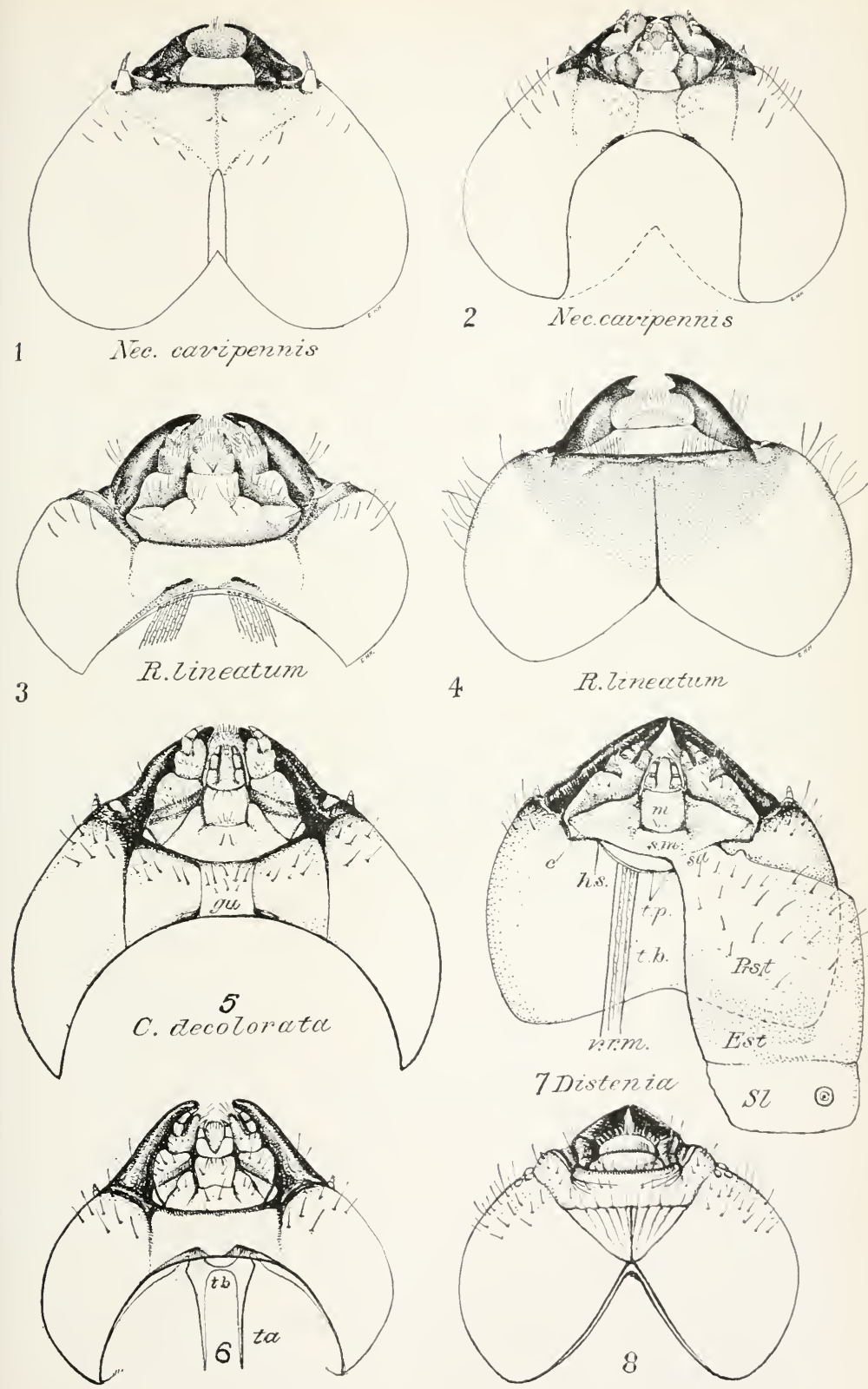

I.nitens
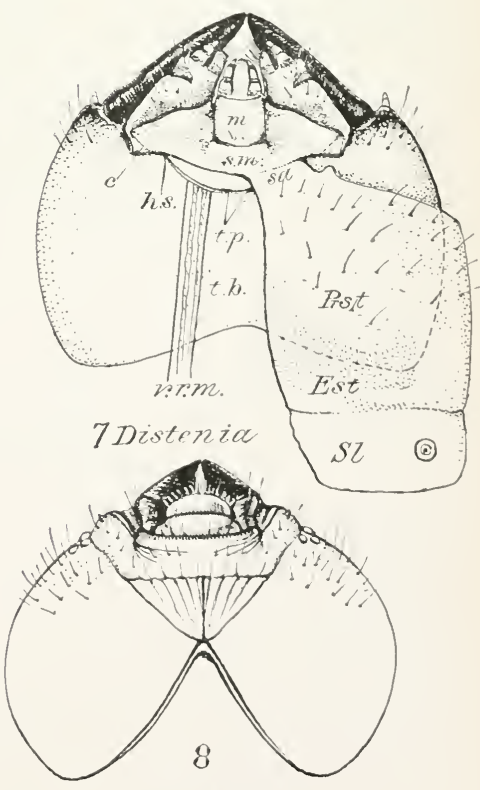

Anthophizax 07.002 


\section{Plate XII}

\section{Head of Larya of Cerambycidae}

Fig. 1.-Ecyrus dasycerus: Ventral view of head.

Fig. 2.-Tetraopes tetraopihalmus: Ventral view of head.

Fig. 3.-Oncideres putator: Dorsal view of head.

Fig. 4.-Dectes spinosus: Ventral view of head.

FIg. 5.-Goes pulverulentus: Ventral view of head.

Fig. 6.-Goes pulverulentus: Dorsal view of head.

Fig. 7-- Tyssodrys haldemani: Dorsal view of head.

FIG. 8.- Wichthysoma heterodoxum: Ventral mouthparts and hypostoma. Fig. 9.-C'yrtinus pygmaeus: Dorsal view of head.

FIG. 10.-Homaesthesis emarginatus: Labrum.

FIG. 11.-Homaesthesis emarginatus: Ventral mouthparts.

Frg. 12.-Homaesthesis emarginatus: Dorsal view of head. 


\section{Plate Xili}

\section{Head of Larvae of Laminae}

FIG. 1.-Psenocerus supernotatus: Ventral view of head.

FIG. 2.-Oberea ruficollis: Ventral view of head.

FIG. 3.-Oncideres cingulata: Dorsal view of head.

FIG. 4.-Acanthocinus spectabilis: Ventral view of head.

Fig. 5.-Monochamus scutellatus: Ventral view of head.

FIG, 6.-Eupogonius tomentosus: Ventral view of head.

FIG. 7.-Hippopsis lemiscata: Ventral view of head.

Fig. S.-Acanthoderes decipiens: Ventral view of head.

Fig. 9.- Synaphoeta guexi: Dorsal view of head. 
PLATE No. XIII.
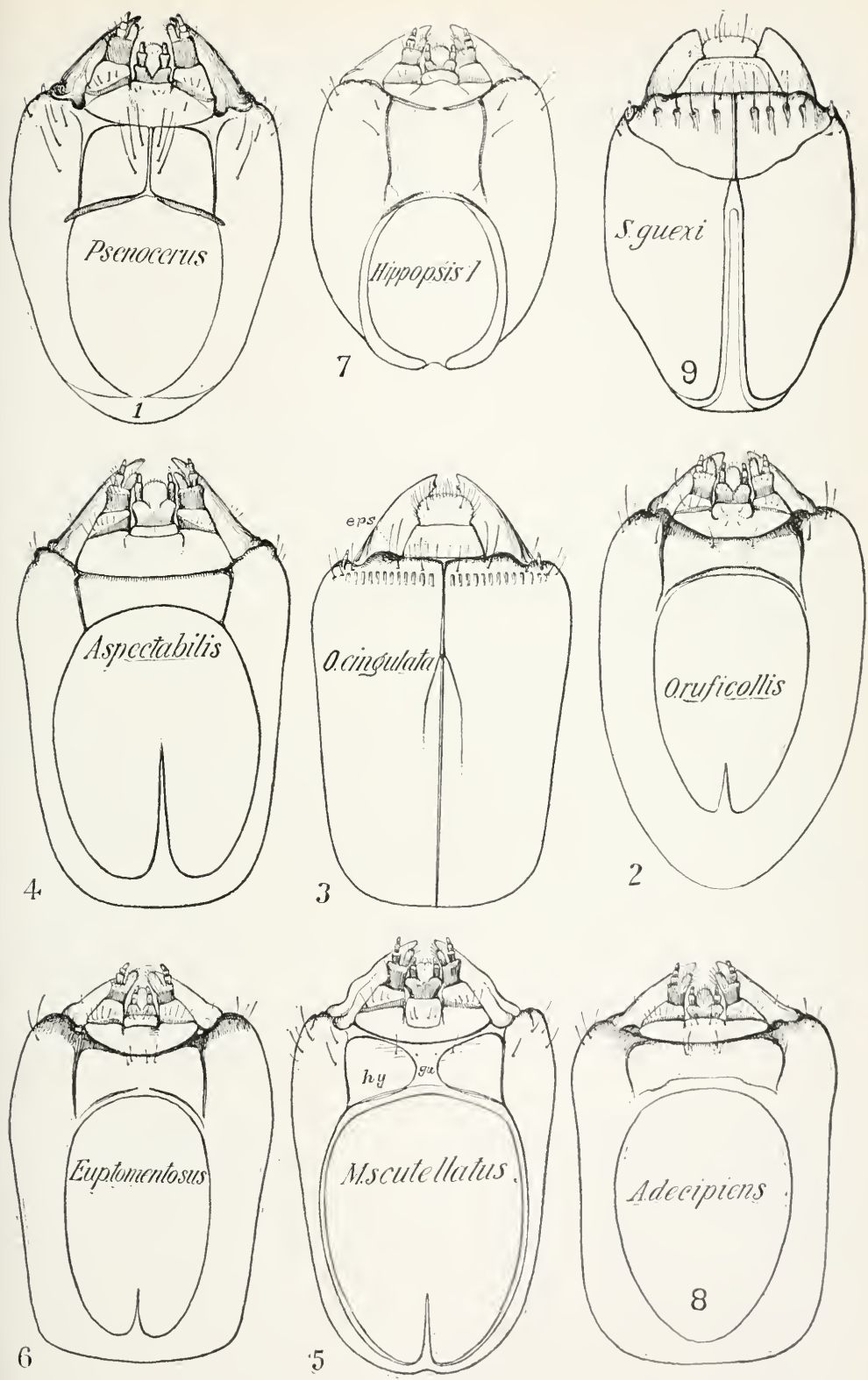
PLATE XIV

\section{Labrua of Larvae of Lepterixae}

[Comparative study principally designed to illustrate characters where species are otherwise quite similar. The line designating the clypeus in living specimens normally appears slightly further forward over the labrum.]

FIG. 1.-Strangalia luteicornis.

Fig. 2.-Strangalia bicolor.

FIG. 3.-Leptura chrysocoma.

Fig. 4.-Typocerus velutinus.

FIG. 5.-Typocerus lunatus.

FIG. 7-Leptura americana.

FIG. 8.-Centrodera decolorata.

FIG. 9.-Lcptura subhamata. 
PLATE No. XIV.
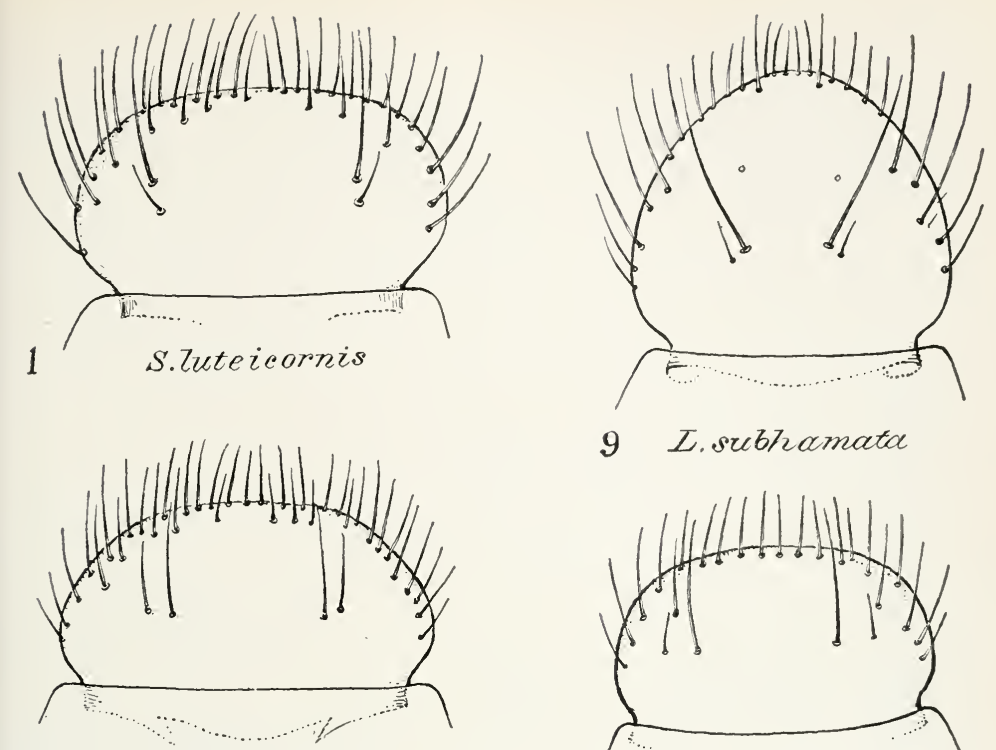

?

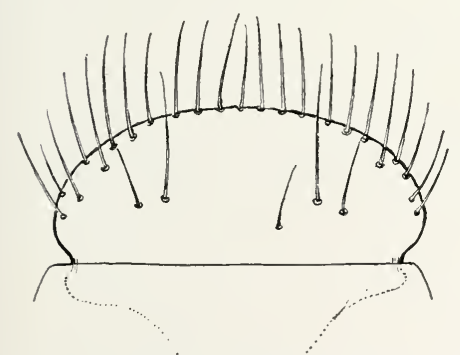

4 Typ.retutinus

9 L.sub7amata
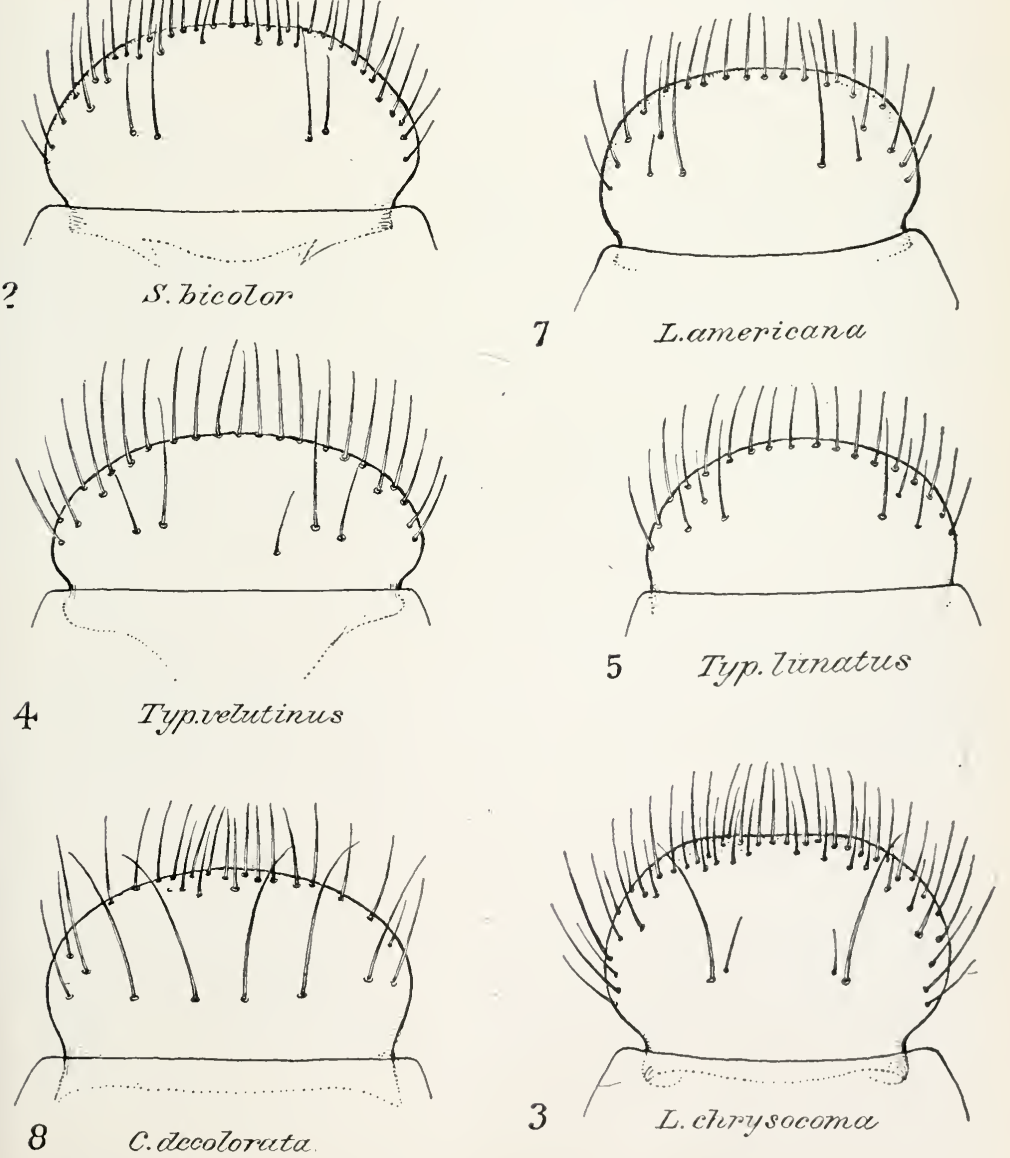


\section{PLITE XV}

\section{Ibdominal Structires of Larvae of Cerambycinae}

Fig. 1. - Rhopalophora longipes: Lateral view of abdominal segment, showing large pleural dise. Fig. 2.-Cyllene pictus: Showing pleural dise obseured by tubercle.

Fig. 3.-Romaleum rufulum: Dorsal ampullae.

FIG. 4.-Elaphidion mucronatum: Dorsal ampullae.

Fig. 5.-Elaphidion alienum: Dorsal ampullae.

Fig. 6.- Yylotrechus insignis: Dorsal ampullae.

Fig. 7.-Xylotrcchus aceris: Dorsal ampullae.

Fig. 8.-Stenosphenus notatus: Pleural dise.

FIG. 9.-Elaphidion subpubescens: Dorsal ampullae.

FIG. 10.-Elaphidion subpubescens: Last ventral ampullac.

FIG. 11.-Callidium aereum: Pleural disc.

Fig. 12.-Rhopalophora longipes: Dorsal ampullae.

F1G. 13.-Tylonotus bimaculatus: Dorsal ampullae.

Fig. 14.-Elaphidion subpubescens: Middle ventral ampullae.

F1G. 15.-Merium proteus: Dorsal ampullae.

FIG. 16.-Curius dentatus: Ventral view of fifth abdominal segment.

FiG. 17.-Hylotrupes amethysinus: Dorsal ampullae. 
PLATE No. XV.

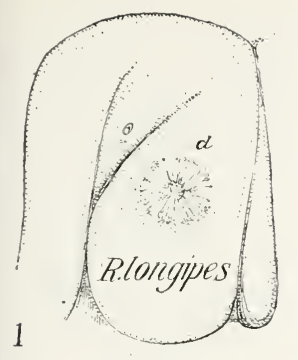

2 C.pictus
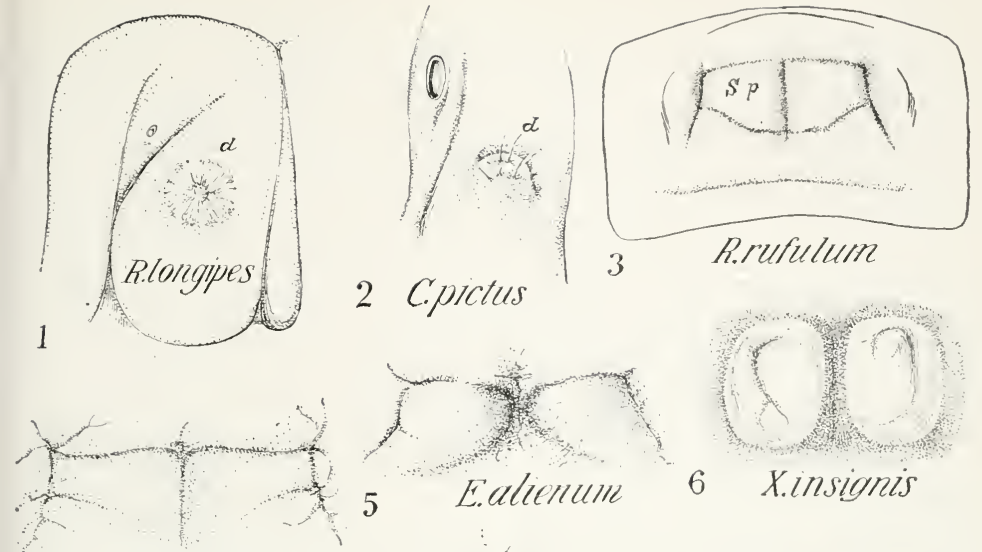

5 E.alienum 6 X.Insignis

4 E.mucrometum

7

7
7 Xaceris

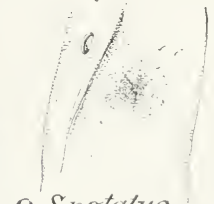

8 Snotulus

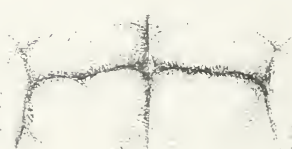

9 Esubpubescens

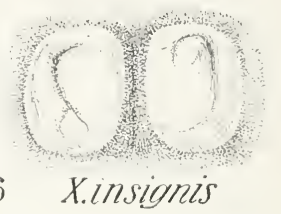

C.

(4)

10 Eisubpubescens

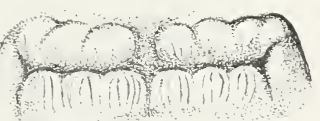

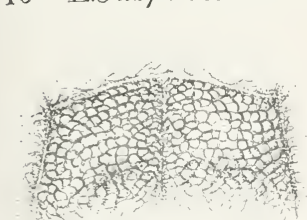

13 Tijlonotils b.

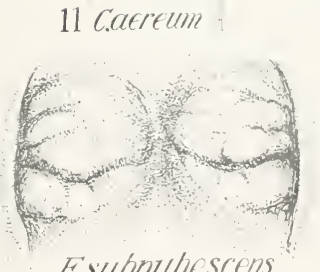

1+ Esubpubescens

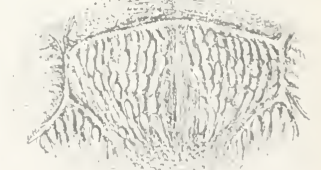

15 uproteles
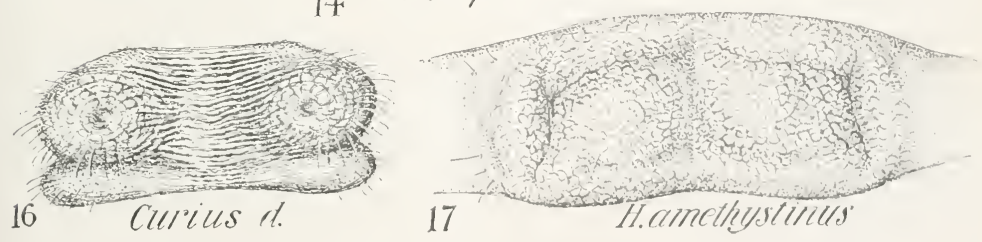


\section{PLATE XVI}

\section{Dorsal Ampullae of Laryae of Laminae}

Fig. 1.-Lcpturgcs symmetricus.

Frg. 2,-Dorcaschema wildii.

FIG. 3.-Dectes spinosus.

FIG. 4.-Psenocerus supernotatus.

Fig. 5.-Acanthoderes decipiens.

FIG. 6.-Graphisurus fasciatus.

Fig. 7.-Eupogonius tomentosus.

Fig. 8.-Mceas pergrata.

Fig. 9.-Saperda lateralis.

FIG. 10.-Adctus subcllipticus.

FIG. 11.-Tetraopes tetraophthalmus.

FIG. 12.-Goes tigrinus.

FIG. 13.-Ataxia crypta.

FIG. 14.-Oberca bimaculata.

Fig. 15.-Oberea bimaculata: From side.

FIG. 16.-Synaphoeta gucxi.

Fig. 17.-Leptostylus macula. 


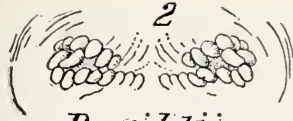

D. witaii

$\left(\begin{array}{c}4 \\ 000000000000000\end{array}\right)$

P.superanotatus
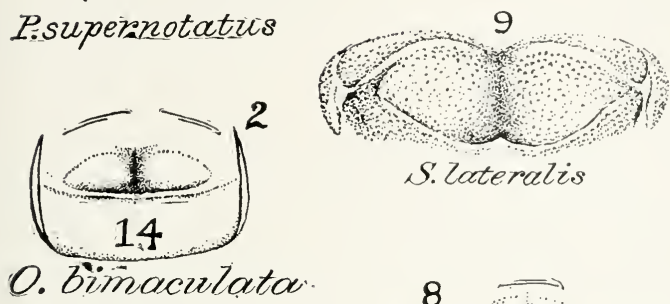

S. Zateralis

15

0 . bimaculata

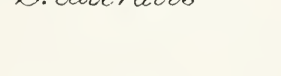

\section{8}

6

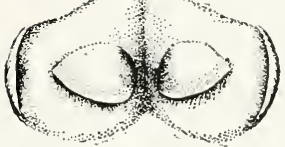

M. pergrato

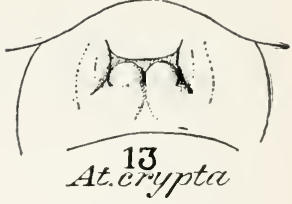

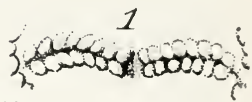

T.symmetricus

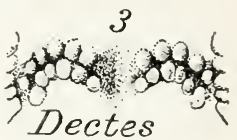

5

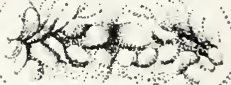

A. decipiens

Graphisurus

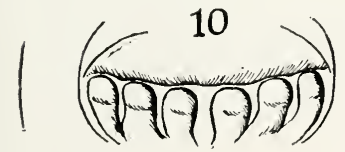

Ad.subellipticus

(17)

L:macuza

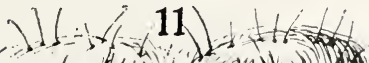

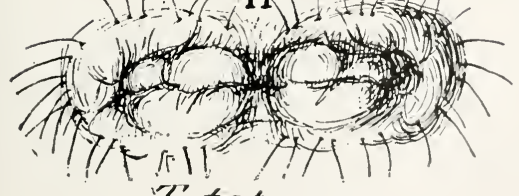

7. tetraop.

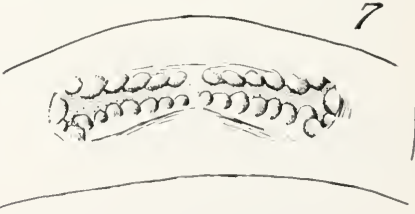

Fup.tomentosus

12

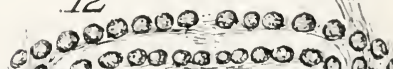

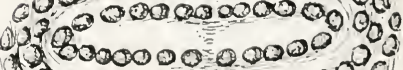
$1000000000000 \%$ G.tigrinus 


\section{PLATE XVII}

\section{I boominal Ftrtéteres of Laryae of Lepturixae}

Fis. 1.-Le ptura rubrica: Dorsal ampullae.

FIG. 2.- Crlochaetes leoninus: Dorsal ampullae.

Fig. 3.-Leptura nigrella: Dorsal ampullae.

Fig. 4.-Bcllamira scolaris: Dorsal ampullae.

FIG. 5.-Leptura nitens: Dorsal ampullae.

FiG. 6.-Gaurotes cyanipennis: Dorsal ampullae.

FIG. 7.-Rhagium linfatum: Dorsal ampullae.

Fig. 8.-Leptura cmarginata: Dorsal ampullae.

Fig. 9.-Leptura sphaericollis: Dorsal ampullae.

Fig. 10.-Leptura obliterata: Dorsal ampuilae.

Fig. 11.-Desmoeerus palliatus: Dorsal ampullae.

Fig. 12.-Lepiura rittata: Dorsal ampullae.

Fig. 13.-Clochactes leoninus: Abdominal spiracle, showing carinate posterior border.

FIG. 14.-Lagoclirus araneiformis: Dorsal ampullae.

Fig. 15.-Michthysoma heterodoxum: Dorsal ampullae.

Fig. 16.-Plectura spinicauda: Dorsal ampullae.

FIG. 17.-Hippopsis lemniscata: Dorsal ampullae.

Fig. 18.-Hippopsis lemniscata: Dorsal ampullae from side.

Fic. 19.-Pogonoehrus: mixtus: Dorsal ampullac." 


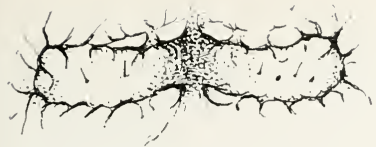

D.parziatus 11

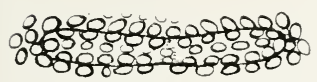

t; G.cyonipennis
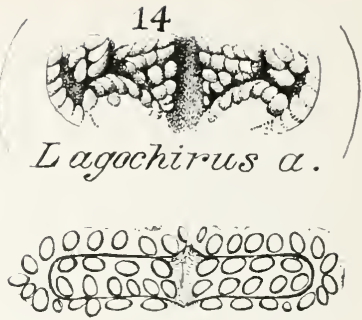

1 I.rubrien

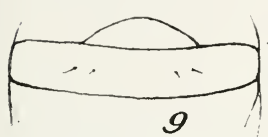

I.sppeacricollis

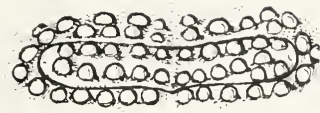

I. nigreller

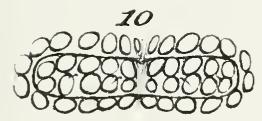

I.obliterata

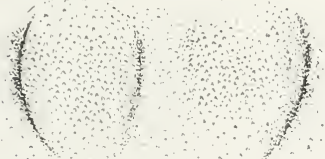

- T.zeoninus

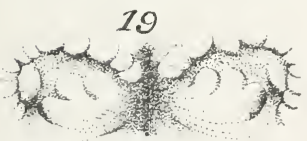

Pog.mixtus

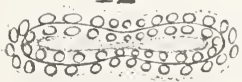
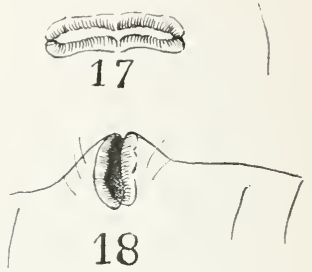

H.Zemniscata
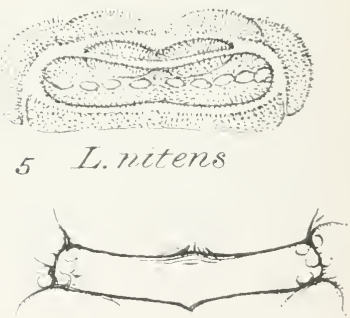

7 R.lineatum

0000000000000000 1000000000000000038 00000000100000
00000000000 8

I. emarginater

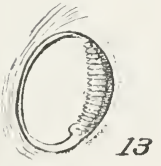

U.leoninus

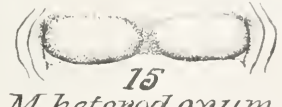

M.heterodoxum
0000000000000 0,000000000000000 $0000000 \% 00000$

1 P.sentaris 


\section{PLATE XVIII}

\section{Thorax of Larvae of Cerambycinae}

FIG. 1.-Obrium rufulum: Prothorax and mesothorax from below.

FIG. 2.-Tylonotus bimaculatus: Prothorax and mesothorax from below.

Fig. 3.-Elaphidion subpubescens: Prothorax and mesothorax from below.

FIG. 4.-Heterachthcs quadrimaculatus: Prothorax and mesothorax from below.

FIG. 5.-Xylotrechus colonus: Prothorax and mesothorax from below.

Fig. 6.-Cyllenc pictus: Prothorax and mesothorax from below.

FIG. 7.-Smodicum cucujiforme: Prosternum and mesosternum.

FIG. 8.-Hylotrupes amethystinus: Prosternum and mesosternum.

FIG. 9.-Romaleum rufulum: Dorsal view of pupa.

FIG. 10.-Euderces picipes: Prosternum and mesosternum.

FIg, 11.-Malcopterus lineatus: Prosternum.

FIG. 12,-Phymatodes variabilis: Protergum. 
PLATE No. XVIII.
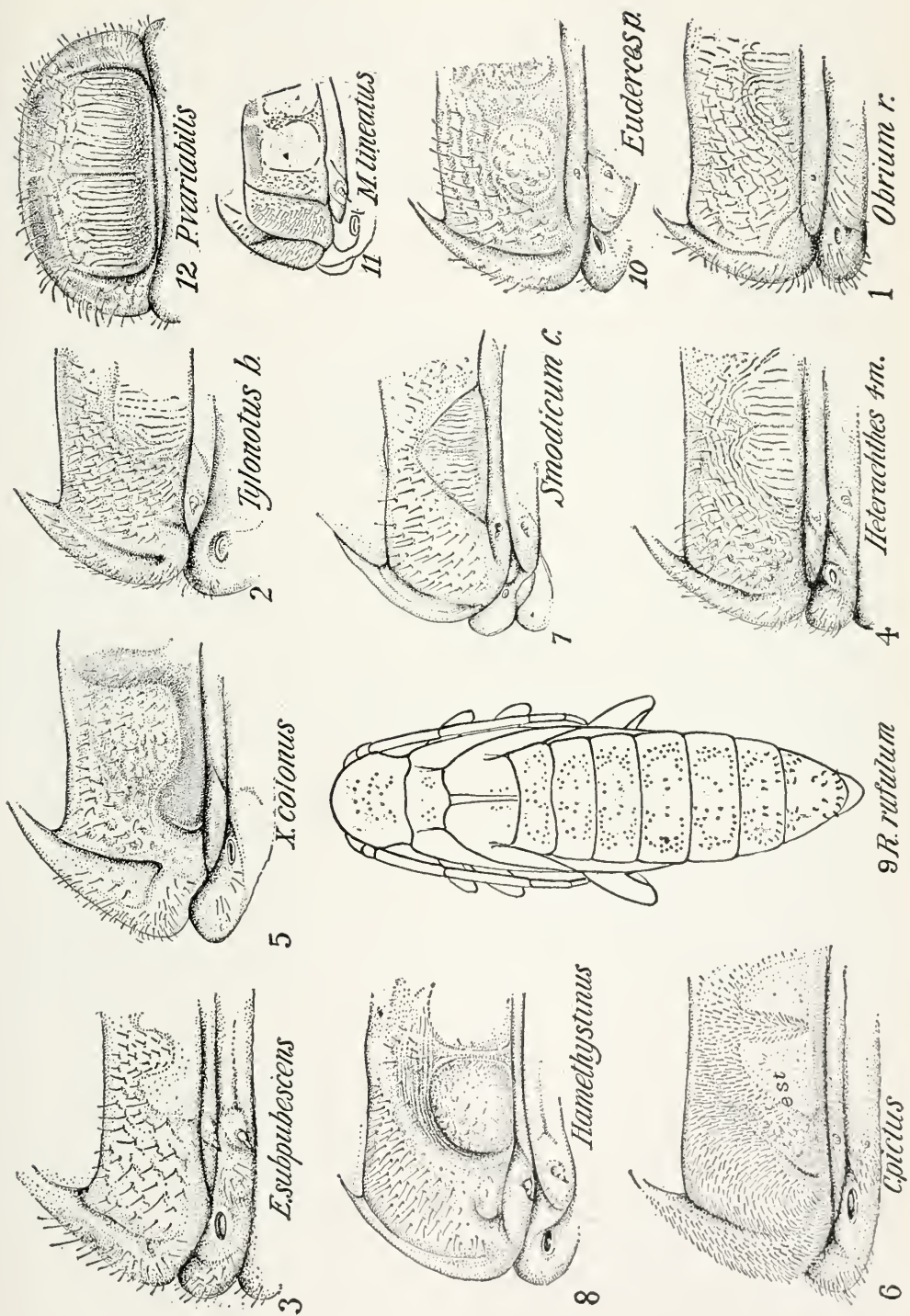


\section{PLATE XIX}

\section{Thorax of Larvae of Cerambycinae}

Fici. 1. - Hylotrupcs amethystinus: Protergum. Note the degree of granulation and the striations; also the median suture.

FIG. 2,-Euderces picipes: Protergum.

Fig. 3.-Malcopterus lineatus: Dorsal view of prothorax, mesothorax, and metathorax.

Fig. 4.-Microclytus gazellula: Protergum.

Fig. 5.-Obrium rufulum: Protergum.

FIG. 6.-Cyrtophorus verrucosus: Protergum.

FIG. 7.-Neoclytus cordifer: Prosternal regions.

FIG. 8.-Curius dentatus: Prothorax, ventral view.

Fig. 9.-Callidium aereum: Protergum.

Fig. 10.-Phymatodes amoenus: Protergum.

Fic. 11,-C'lytanthus ruricola: Protergum.

Fig. 12.-Merium proteus: Protergum.

Fig. 13.-Romaleum rufulum: Prosternum. 

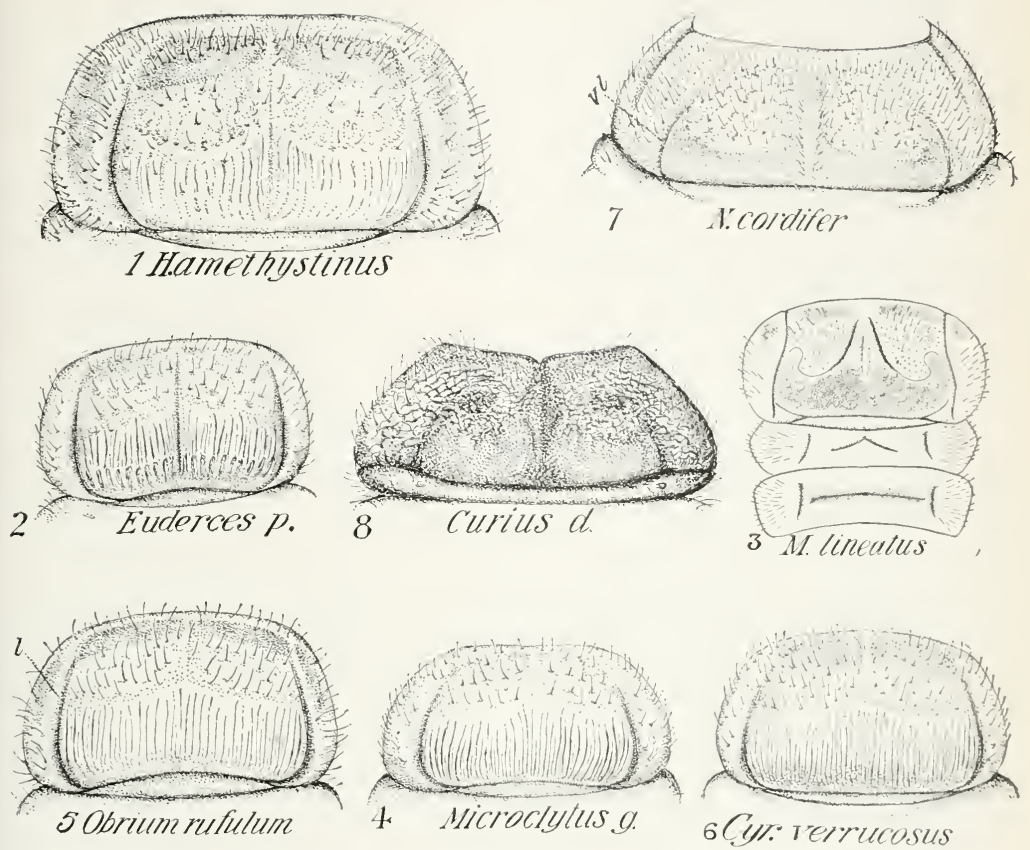

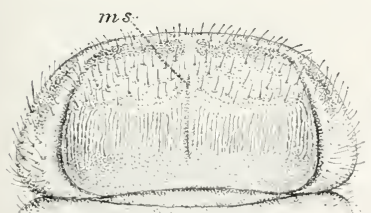

9 Call aereurn

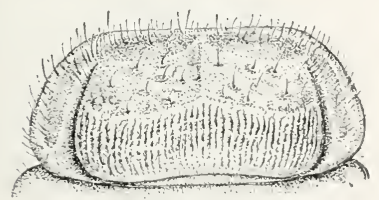

12. Merium $p$.
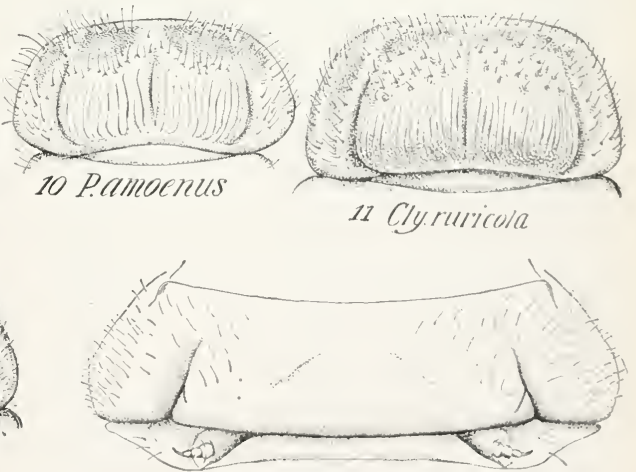

13 hirifilum 


\section{PLATE XX}

\section{Thorax of Larvae of Cerambycinae}

Fig. 1.-Curius dentatus: Protergum.

Fig. 2.-Oeme rigida: Dorsal view of prothorax, mesothorax, and metathorax.

Fig. 3.-Cyllene pictus: Protergum, mesotergum, and metatergum.

FIG. 4.-Oeme rigida: Prosternum.

Fig. 5.-Xylotrechus colonus: Protergum.

Fig. 6.-Romaleum rufulum: Protergum, mesotergum and metatergum. Compare the sutures of the metathorax with those of Cyllene (Fig. 3). 

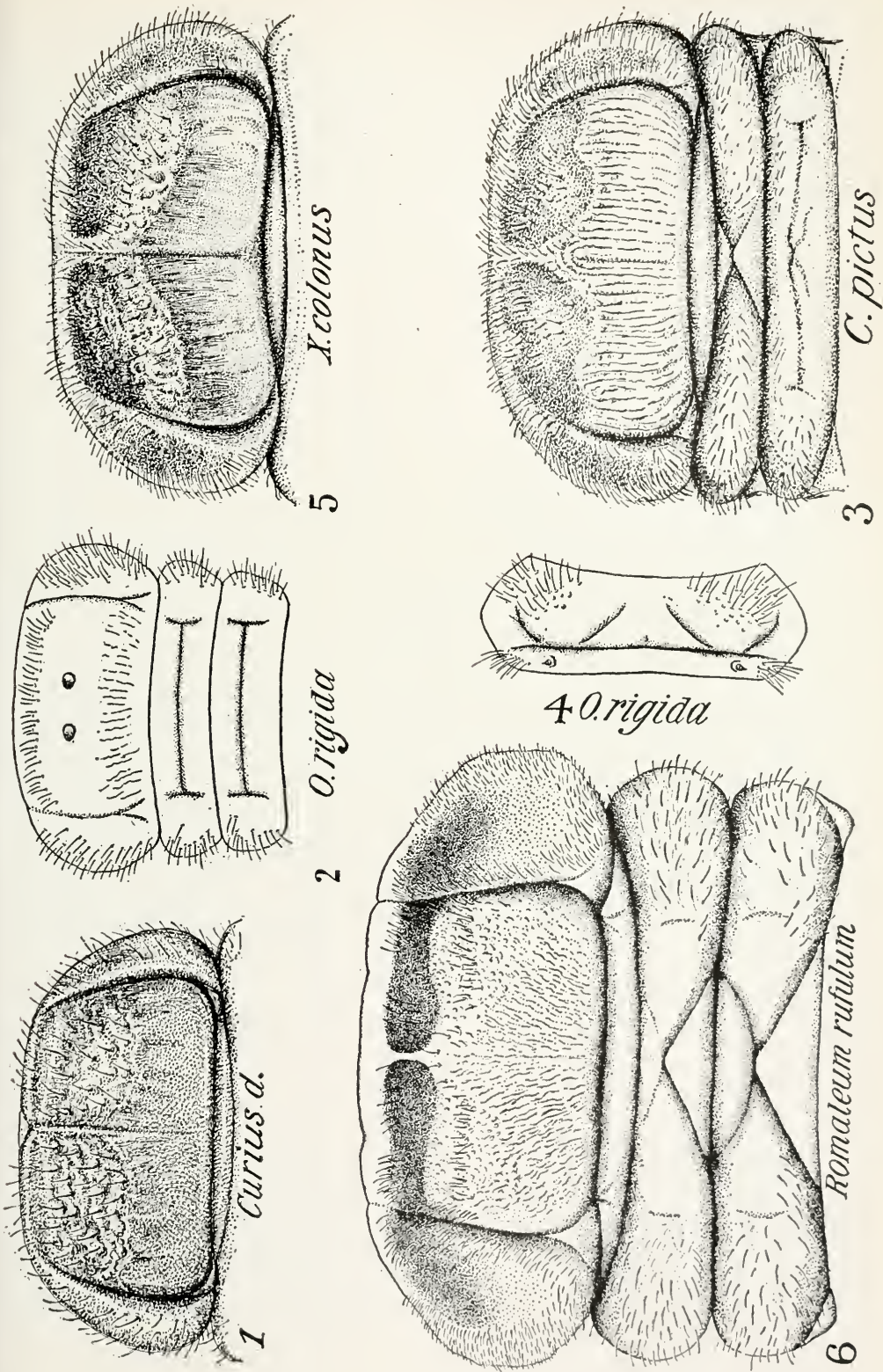


\section{PLATE XXI}

\section{Thorax of Larvae of Cerambycinae}

FiG. 1.-Rhopalophora longipes: Protergum.

FIG. 2.-Callimoxys fuscipennis: Protergum.

FIG. 3.-Elaphidion villosum: Protergum.

Fig. 4.-Tylonotus bimaculatus: Protergum.

Fig. 5.-Elaphidion subpubeseens: Protergum, mesotergum, and metatergum.

Fig. 6.-Stenosphenus notatus: Protergum.

Fig. 7.-Eburia quadrigeminata: Protregum.

Fig. 8.-Elaphidion alienum: Protregum. 

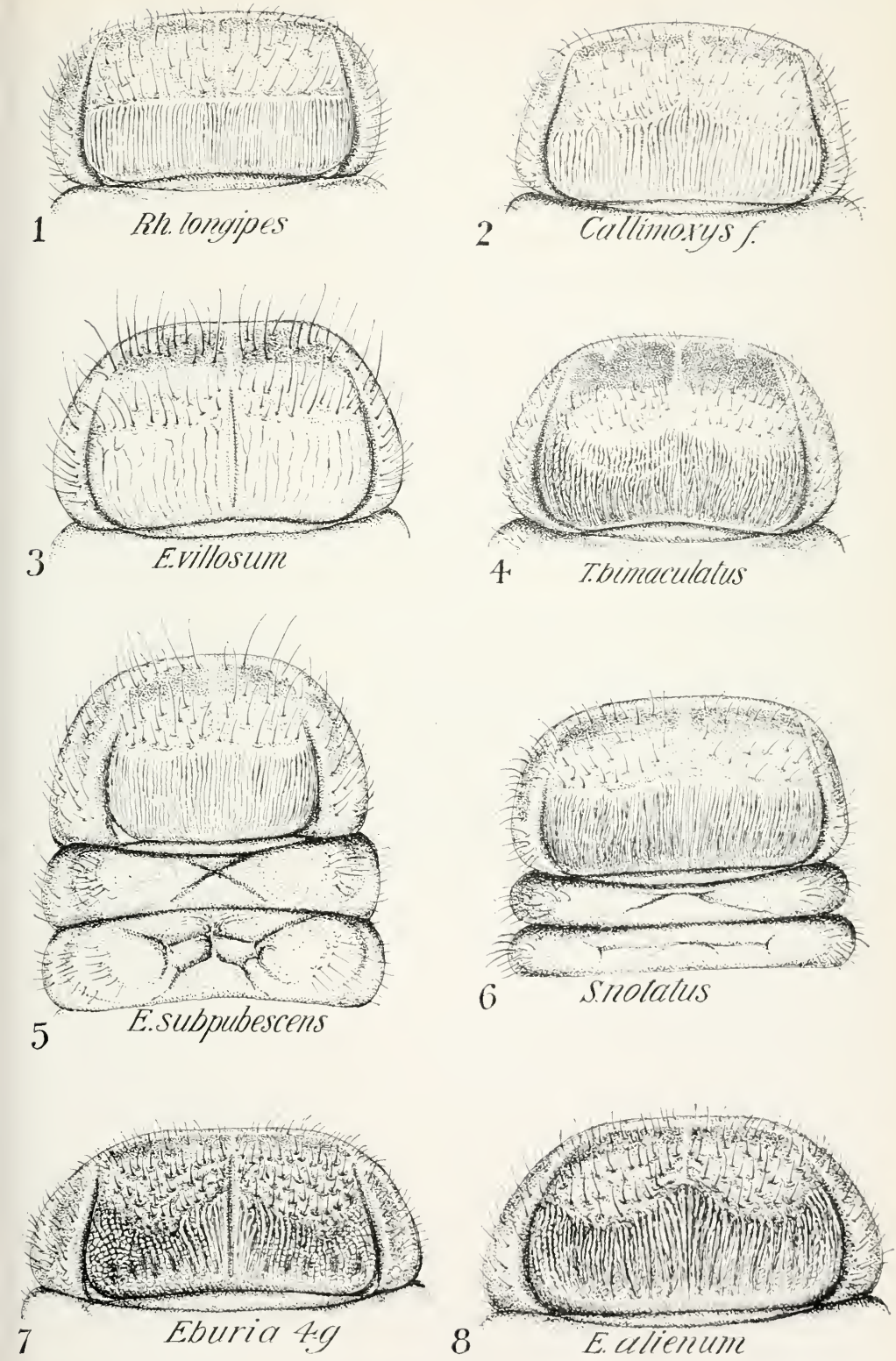

4. Thimaculatus

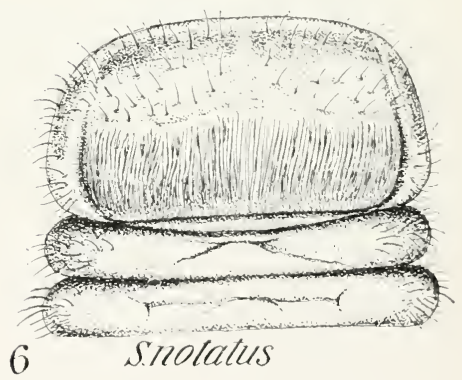




\section{PLATE XXII}

\section{THORIX AND LEGS OF LARVAE OF LEPTIRINAE}

Firs. 1-3.-Comparison of mesonotum and metanotum in different species of lepturine larvae. The illustrations show also the first abdominal ampullae.

Fici. 1.-Leptura proxima.

Fig. 2.-Typocerus velutinus.

Fig. 3.-Leptura canadensis.

Fir. 4.-Leptura rubrica: Comparison of prosternum. Note the difference in pubescence on the eusternum.

Fig. 5.-Bellamira scalaris.

Fig. 6.- Anthophilax attenuatus: Comparison of slender and robust legs. Note especially the difference in the tarsus.

FIG. 7.-Bellamira scalaris.

FIG. 8.- - Vecydalis cavipennis: Pronotum, showing rugose texture.

Fic. 9.- Tecydalis cavipennis: Prosternum, showing triangular, finely pubescent eusternum and coxae nearly meeting at middle.

FIG. 10.- Neydelis cavipennis: Dorsal ampullae of third abdominal segment, showing irregularly disposed tubercles.

FIG. 11.-Rhagium lineatum: Prosternum. Note the large, roundly trapezoidal eusternum.

Fis. 12.-Rhagium lineatum: Mesosternum.

Fig. 13.-Rhagium lineatum: Metasternum. Note that these segments are not tukerculate, as they are in nearly all other lepturine larvae.

lig. 14.-Centrodera decolorata: Caudal spines or cerci.

FIG. 15.-Pachyta monticola: Caudal spines or cerci.

Fig. 16.-Anthophilax sp.: Caudal spines or cerci.

FIG. 17.-Anthophilax attenuatus: Caudal spines or cerei. 



\section{PLATE XXIII}

THORAX OF LIRTIE OF ('ERAMBYCIDAE

Fig. 1.-Ataxia crypta: Pronotum.

Fig. 2.-Ataxia crypta: Prosternum.

Fig. 3.- Acanthoderes decipiens: Prosternum.

FIG. 4.-Acanthoderes decipiens: Pronotum.

FIG. 5.- Itimia dorsalis: Protergum, showing pronotum, posteriorly velvety pubescent, and the large irregular glabrous area.

Fig. 6.-Criocephalus productus: Protergum, showing pronotum, posteriorly finely asperate, and glabrous spots.

Fig. 7.-Ptychodes trilineatus: Pronotum.

FIG. 8.-Monochamus scutellatus: Pronotum.

FIG. 9.-Saperda hornii: Prosternum.

Fig. 10.-Saperda concolor: Prosternum.

Fig. 11.-Ulochaetes leoninus: Showing asperities of protergum and well impressed lateral sutures limiting the pronotum. 
PL.ATE No. XXIII.

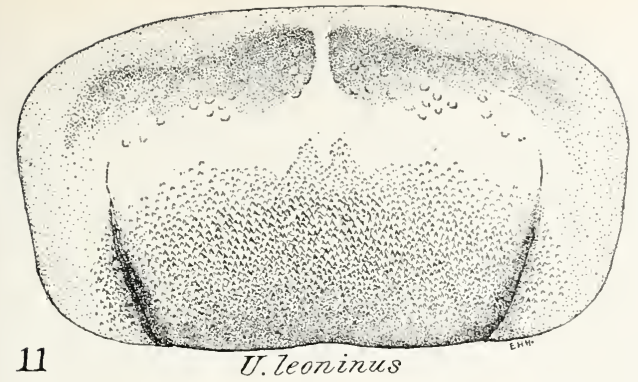

A.t.crypto

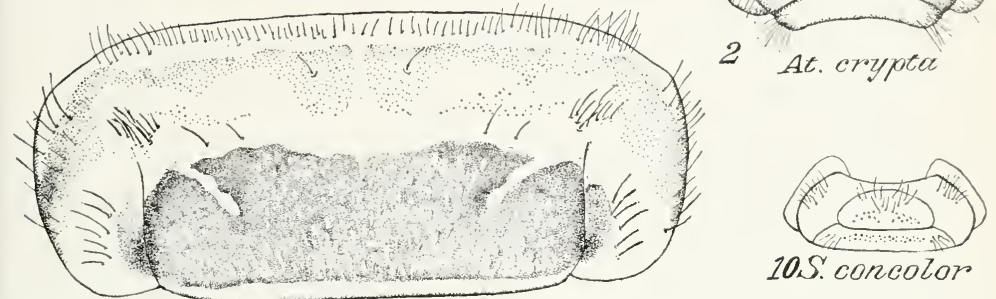

\section{Pbyctuodes}
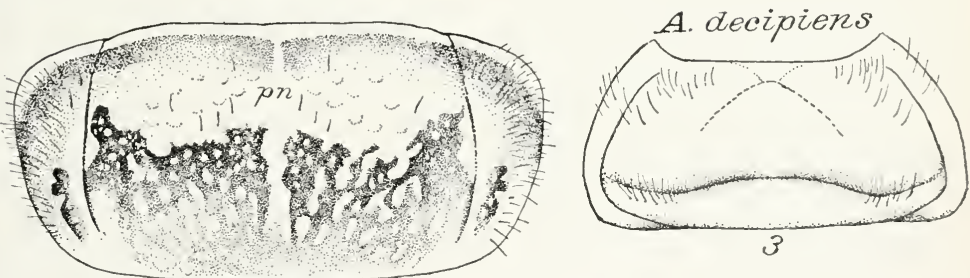

6 c. poroductus.
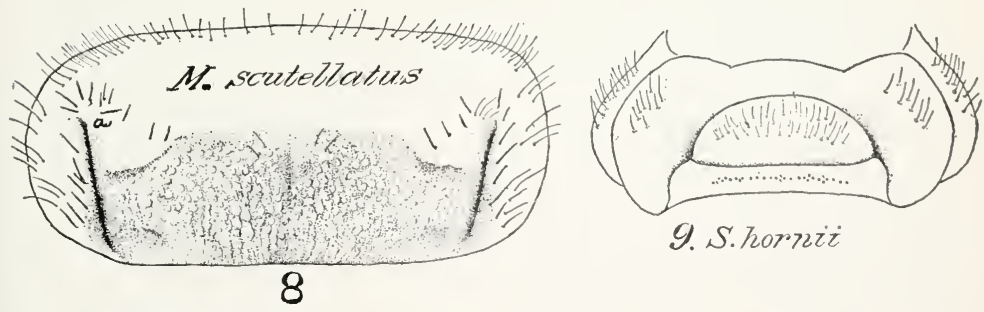

\section{8}
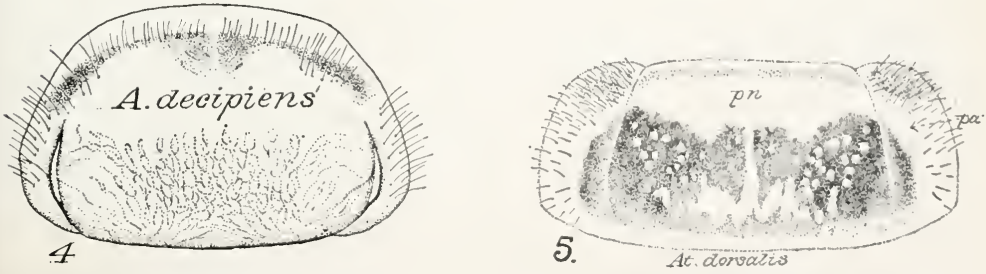


\section{PLATE NXIV}

\section{Prothorax of Larvae of Laminae}

FIG. 1.-Cyrtinus pygmaeus: Pronotum.

Fig. 2.-Plectrura spinicauda: Pronotum.

Fig. 3.-Oberea ruficollis: Prosternum.

Fig. 4.-Ecyrus dasycerus: Prosternum.

FIG. 5.-Adetus subellipticus: Prosternum.

Fig. 6.-Liopus variegotus: Pronotum.

Fig. 7.-Oberea ruficollis: Pronotum.

Fig. 8.-Psenocerus supernotatus: Pronotum.

FIG. 9.-Dorcaschema wildii: Pronotum.

FIG. 10.-Michthysoma heterodoxum: Pronotum.

FIG. 11.-Goes tigrinus: Prosternum.

Fra. 12,-Goes tigrinus: Protergum.

FIG. 13.-Hippopsis lemniscata: Prosternum, mesosternum, amd metasternum.

FIG. 14.-Eupogonius tomentosus: Pronotum.

Fig. 15.-Saperda candida: Prosternum. 

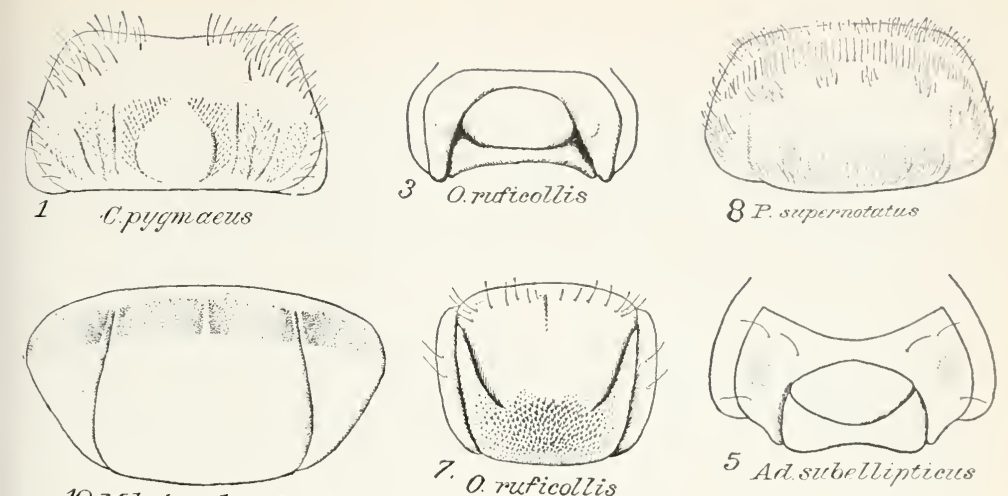

10 A1.heteroetoxzerm
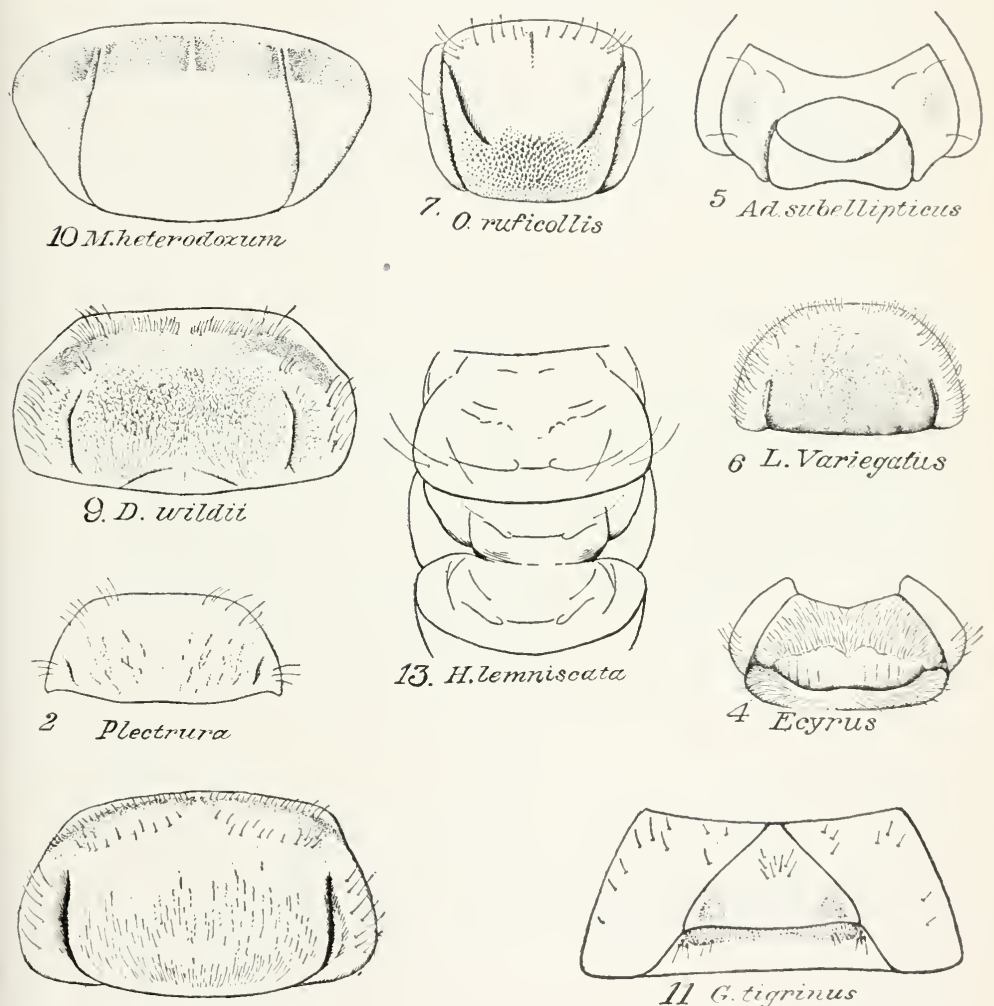

\section{Eup.tomentosus}
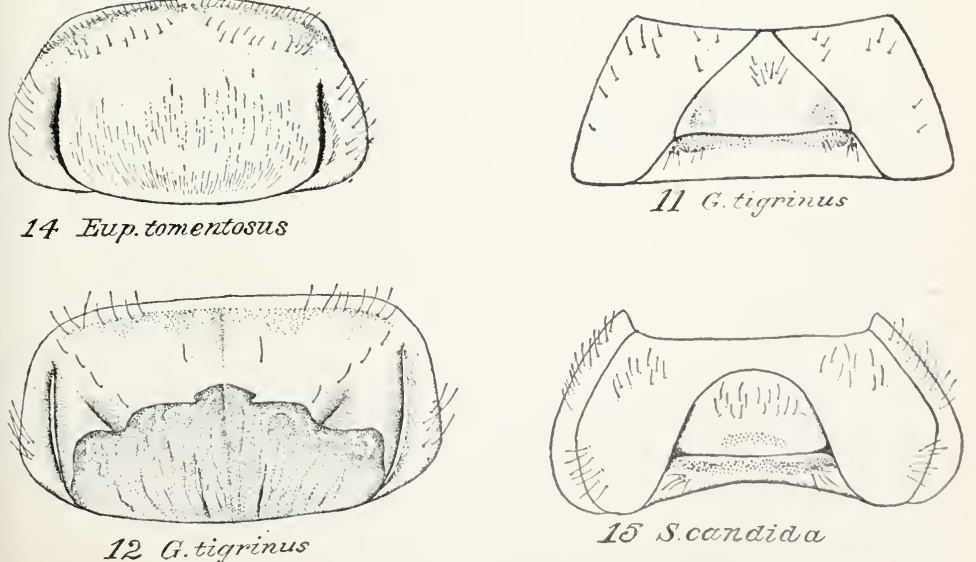


\section{PLATE XXY}

\section{Larvae and Pupa of Aseminae}

Fig. 1.- Asemum moestum: Lateral view of larva, showing lateral folds of the body.

FIG. 2.-Asemum moestum: Dorsal view of larva, showing velured pronotum and sutures of terga. Fig. 3.-Atimia dorsalis: Dorsal view of larva.

Fig. 4.-Atimia dorsalis: Latero-dorsal view of larva to show bilobed ampullae. Fig. 5.-Criocephalus productus: Dorsal view of pupa. 
PLATE NO. XXV.

\section{(이연.}
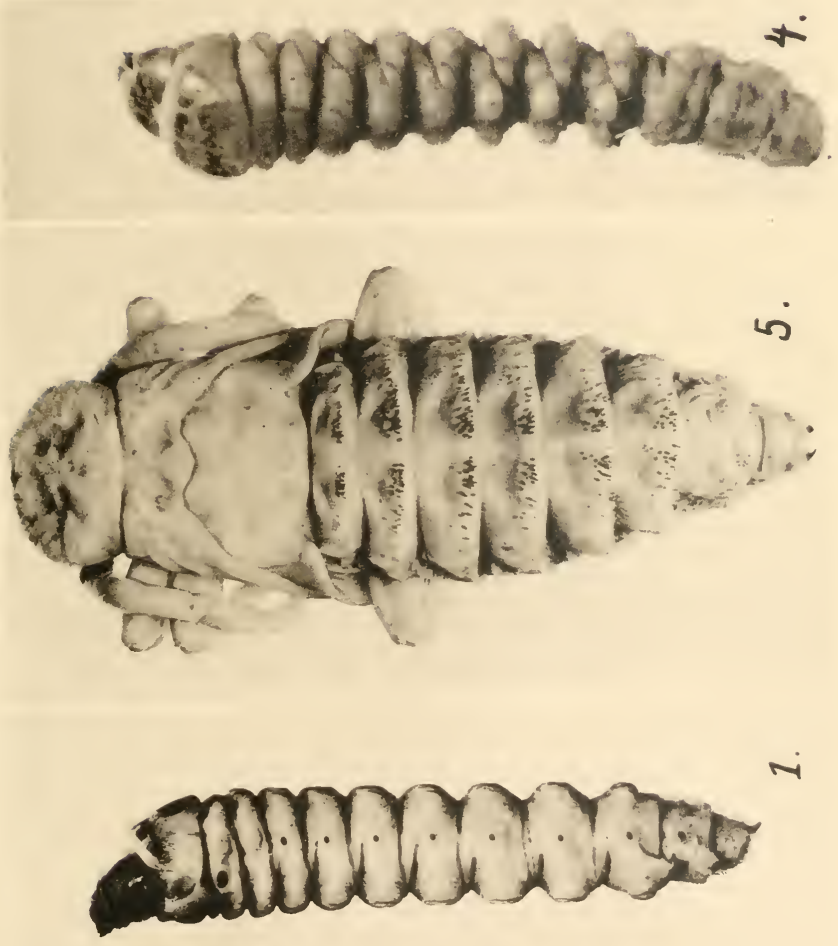

$$
\text { Ni }
$$






\section{PLATE XXVI}

\section{LARVAE OF ('ERAMBYCINAE}

Fig. 1.-C'yllene pietus: Dorsal view of larva.

FIG. 2.- ('yllene pictus: Lateral view of larva. Note that the prosternellar fold in front of the spiracle passes beyond it.

Fig. 3.-Dysphaga tenuipes: Dorsal view of pupa.

Fig. 4.-Parandra brunnea: Dorsal view of head and thorax of larva, to show ehitinous asperities.

FIG. 5.-Hylotrupes ligneus: Lateral view of larva. Note that the prosternelar fold is broadly fused at the extremity.

FIG. 6.-Elaphidion subpubescens: Lateral view of larva. 
PLATE NO. XXVI.
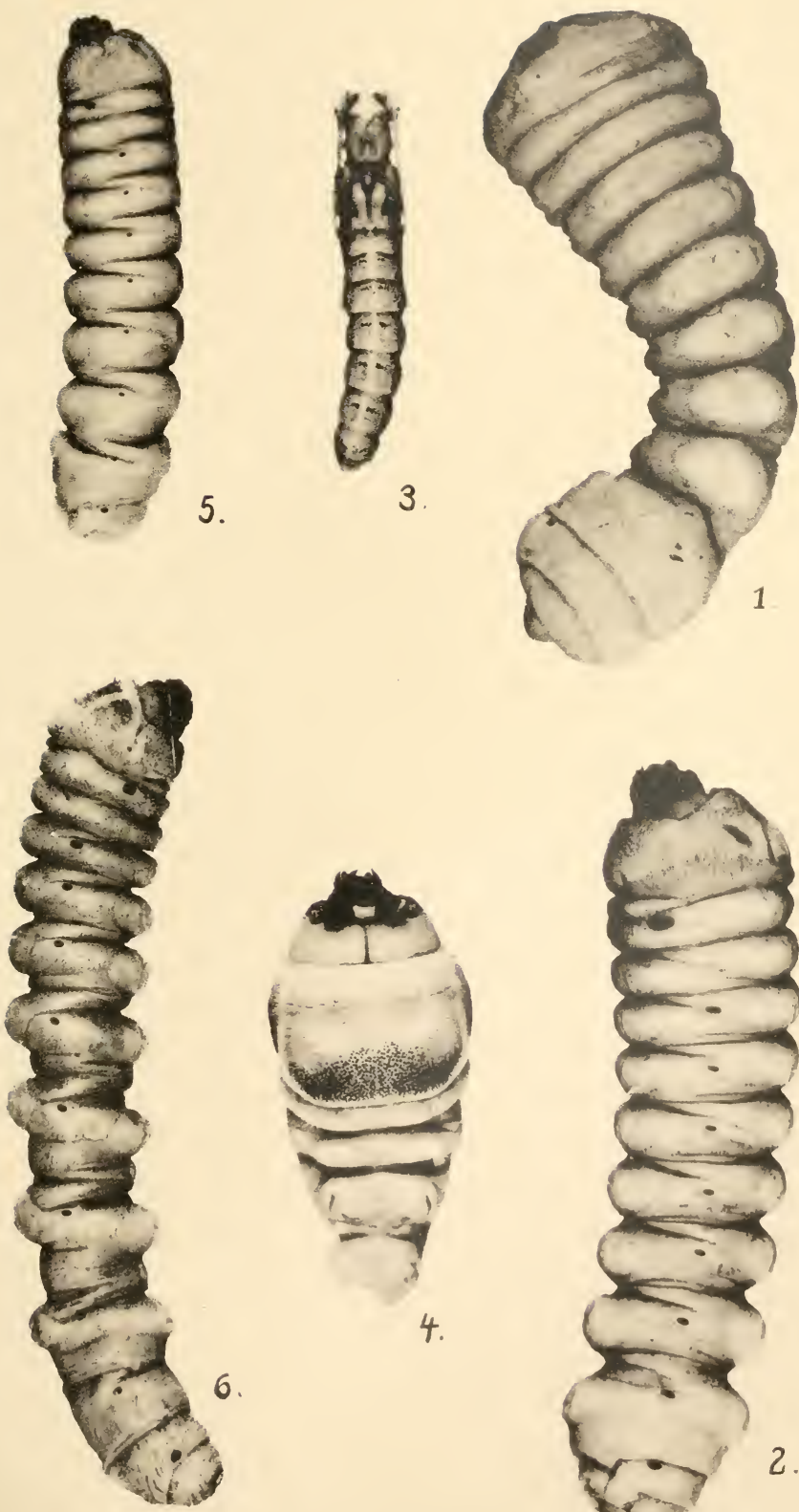

4.

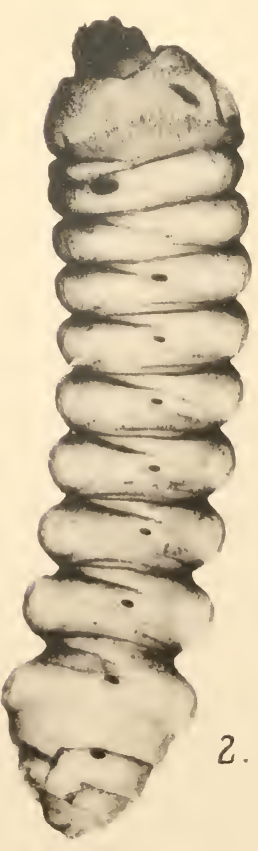






\section{PLATE NXVII}

\section{LARVAE OF LEPTLRINAE}

Fig. 1. Leptura obliterata: Dorsal aspect of larva, showing tubercles of ampullae, and pigmentation on ant rior area of protergum so characteristic of lepturine larvae.

FIG. 2.-Encyclops caeruleus: Lateral aspect of larva, to show the prominent, projecting, bilobed ampullae.

Fig. 3.- Tragidion armatum: Dorsal view of thorax and abdomen, to show the prominent protergal plates.

Fic. 4.-Curius dentatus: Ventral view of larva. 
PLATE NO. XXVII.
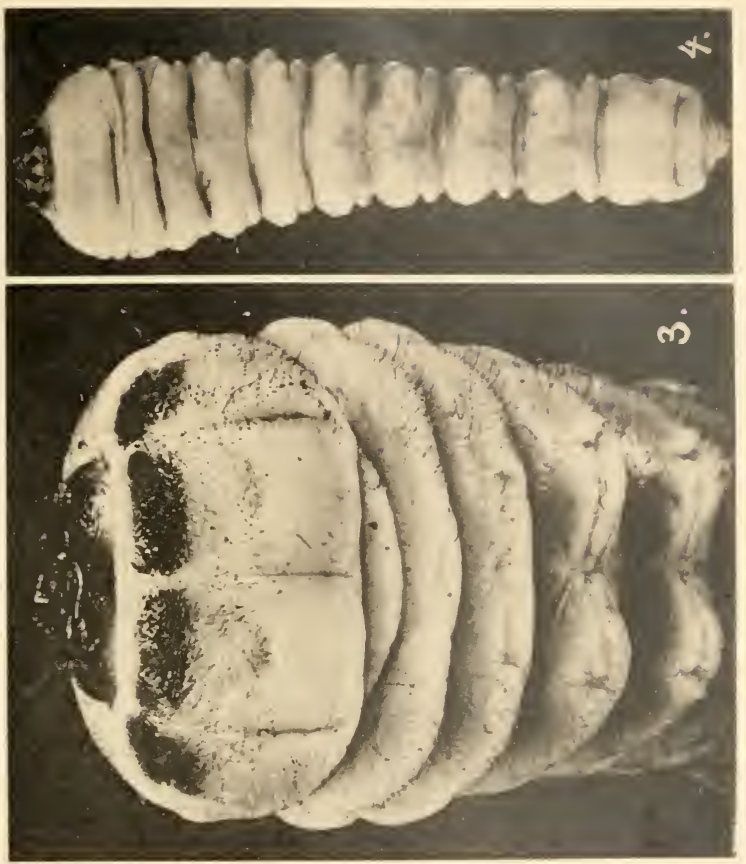

v
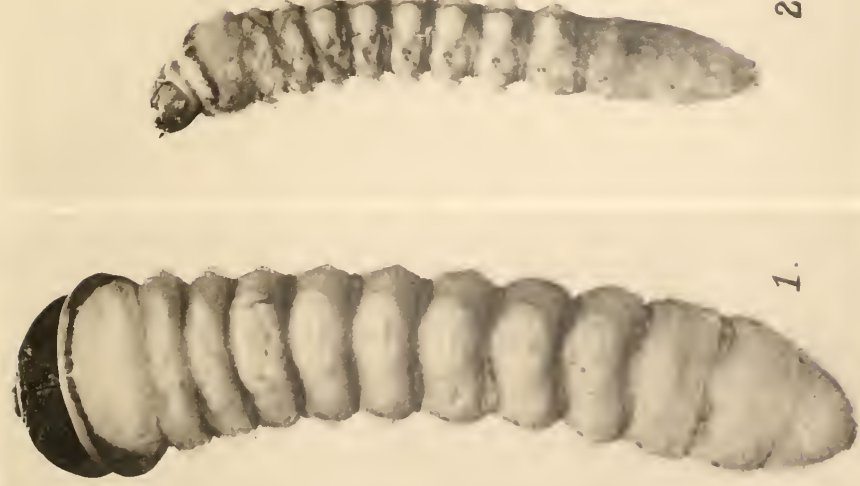


PLATE XXVIII

\section{LARVAE OF CERAMBYCIDAE}

Fig. 1.-Goes tigrinus: Lateral riew of larva.

Fig. 2.-Leptura canadensis: Latero-ventral aspeet of larva, showing general form, tubercles of ventral ampullae, and protuberant epipleurum.

Fig. 3.-Eburia quadrigeminata: Dorsal view of larva.

Fig. 4.--Aeanthophilax attenuatus: Lateral aspeet of larva. Note that the tubercle on the epipleurum is well indieated, as also the eaudal spines.

FIG. 5.-Chion cinctus: Lateral view of larva. 

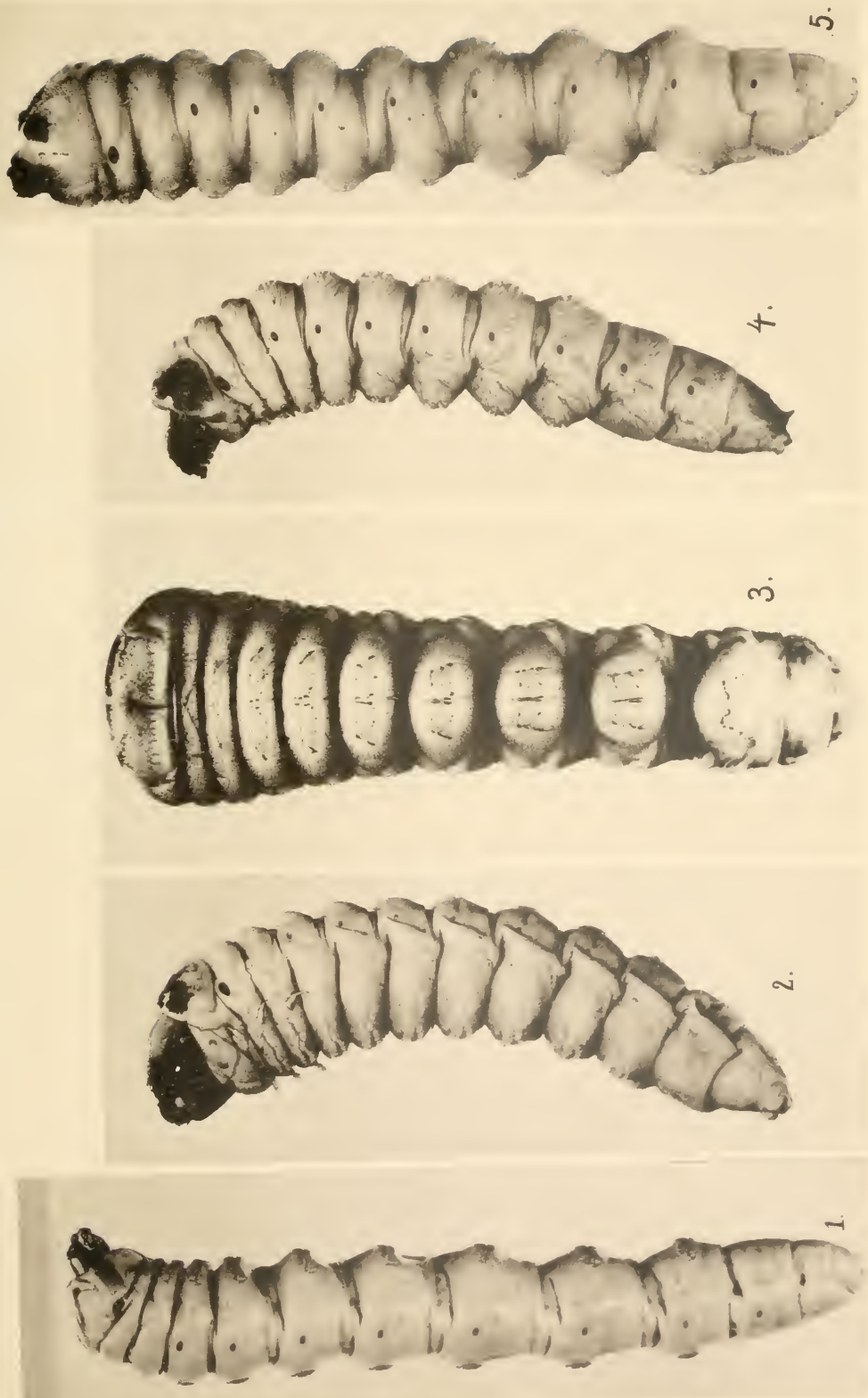



\section{PLITE XXIX}

\section{LARYAE OF CERAMBYCIDAE}

Fu,. 1. - Physocnemum andrea: Lateral view of larva.

Fig. 2. Clochactes leoninus: Dorsal aspeet of larva. Note the texture of the pronotum and the two lateral impressed lines on the ampullae. The form is abnormally eompressed on the left side.

Fig. 3. Rhagium lineatum: Dorsal view of larva, to show depressed form.

Fig. 4. - Saperda calcarata: Lateral view of larva.

Fig. 5.- Monilema sp.: I orso-lateral view of larva-a robust typo. 

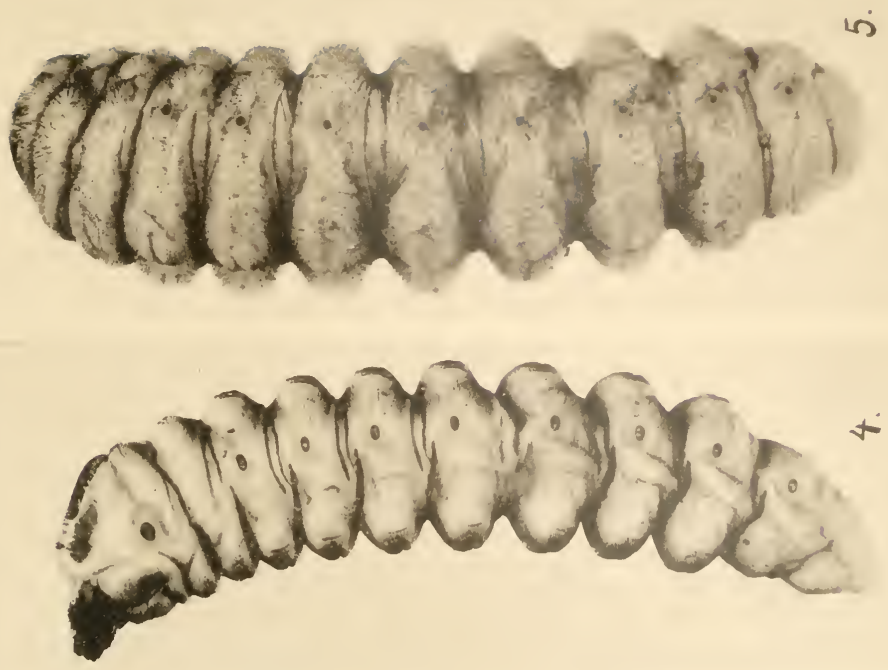

ginararian
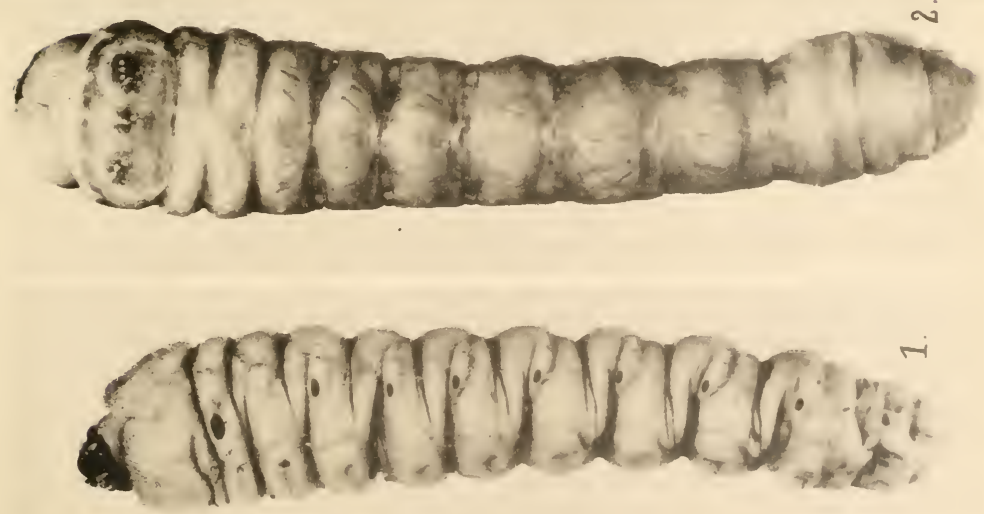

$57951-14$ 
PLATE XXX

\section{Laryae and Plpa of ('erambycidae}

FIG. 1-Distenin undata: Dorsal view of larva.

Frci. 2.-Distenia undata: Lateral view of larva.

Fif. 3.-Saperda calcarata: Lateral view of pupa.

Fici. 4.-Strangatia luteicornis: Lateral aspect of larva, to show general form.

Fig, 5,-Obrium rufulum: Lateral view of larva, showing projecting ampullae. 
PLATE NO. XXX.
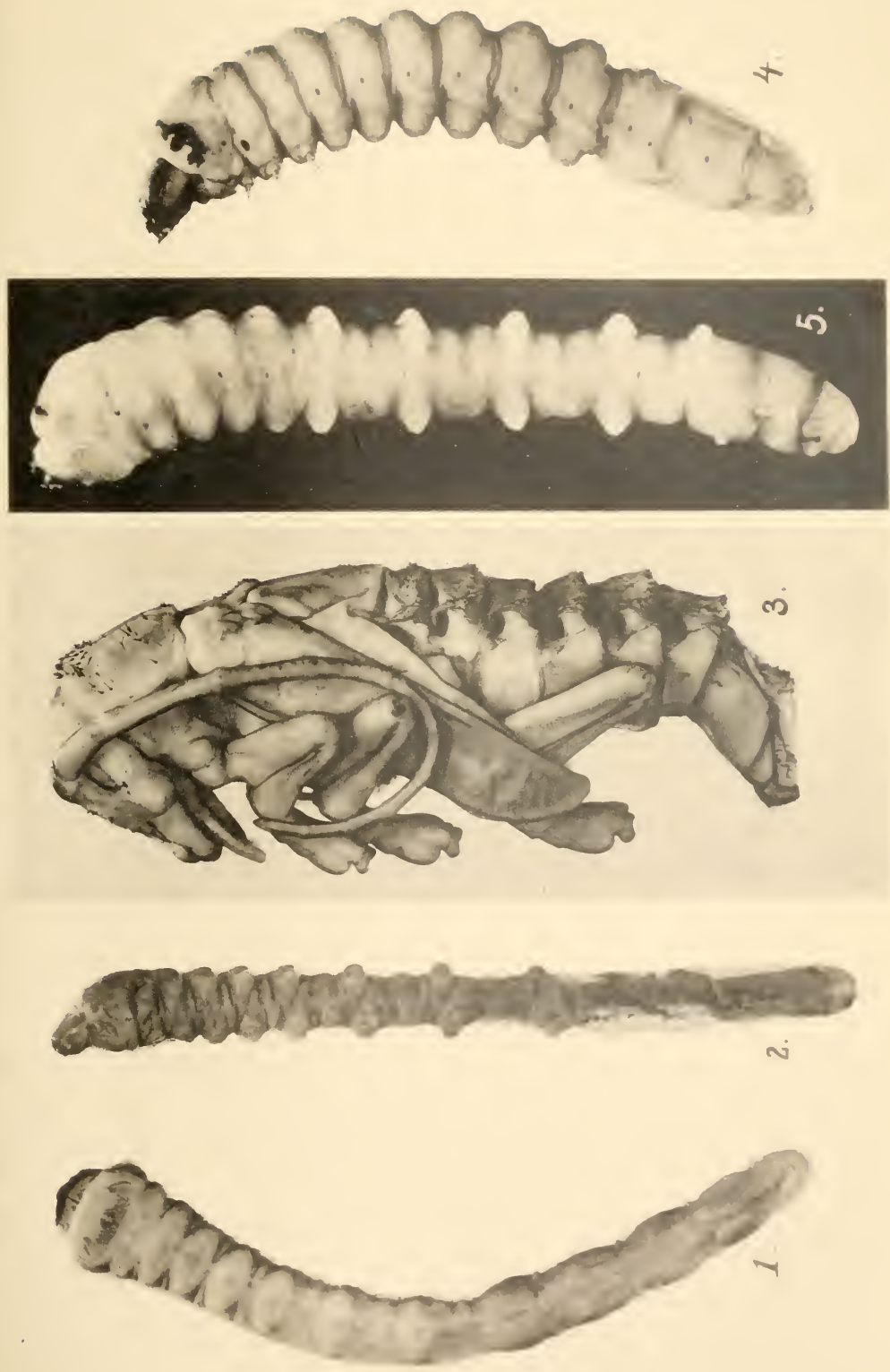

$57951-14^{\frac{1}{2}}$ 


\section{PLITE YYY}

Larvae of Laminae aNd PLPA OF Lepturin.ae

Fig. 1.-Hippopsis lemniscata: Lateral view of larva.

Fig. 2.-Ecyrus dasycerus: Lateral view of larva.

Fig. 3.-Leptostylus macula: Dorsal view of larva.

Fig. 4.-Ataxia crypta: Lateral view of larva.

FIG. 5.-Oncideres cingulata: Lateral view of larva.

FIG. 6.-Bellamira scalaris: Lateral aspect of pupa.

FIG. 7.-Leptura nitens: Dorsal aspect of pupa.

FIG. 8.-Desmocerus palliatus: Dorsal aspect of pupa.

FIG. 9.-Rhagium lincatum: Ventral aspert of pupa. 

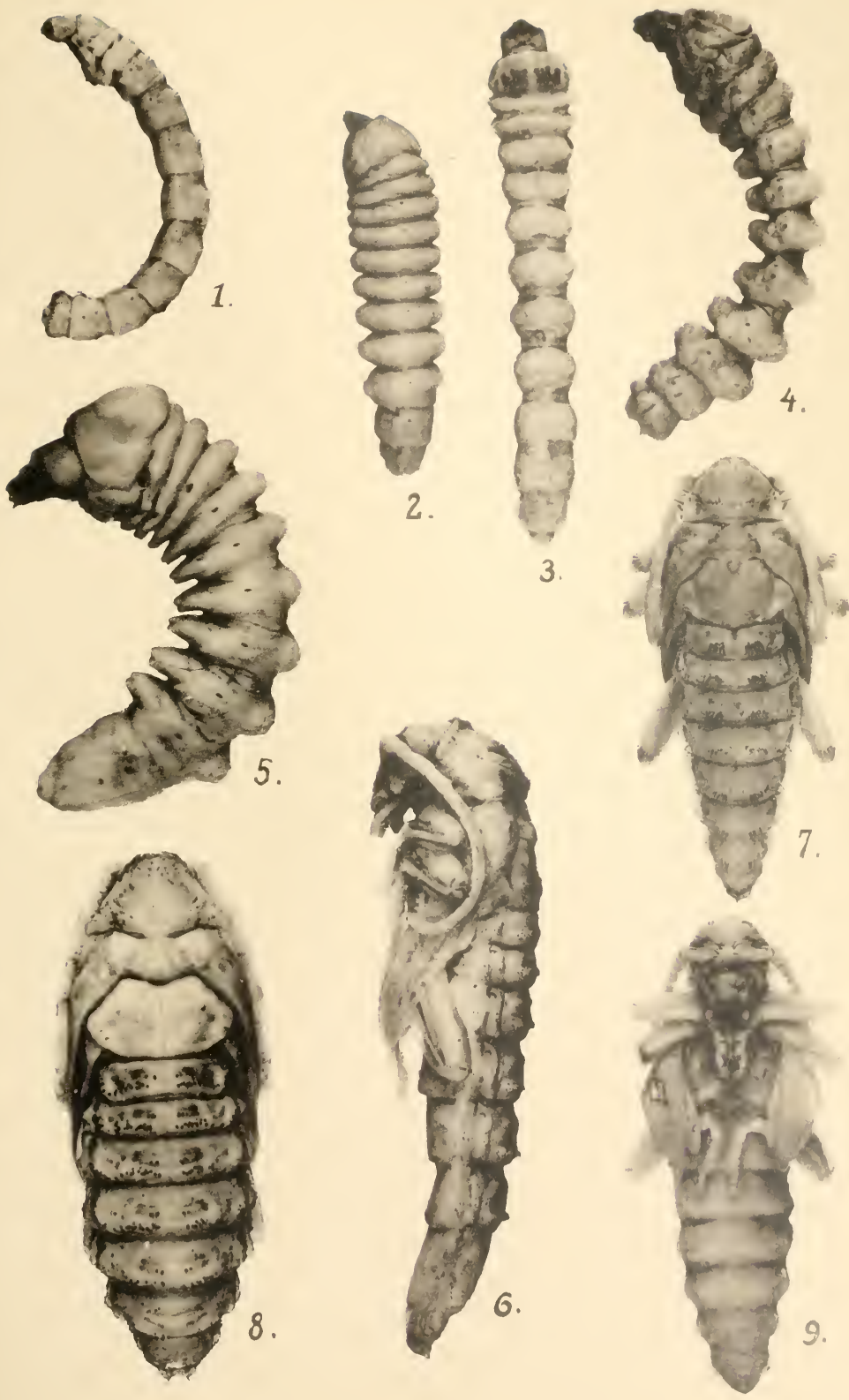


PLATE XXXII

L.ARYAE AND PUPAE of LaMinaE

Fic. 1. Tetraopes tetroophthalmus: Lateral view of larva. Note the hairy body. Fig. 2.-Oncidercs cingulata: Lateral view of pupa.

Fig. 3.-Graphisu us fasciatus: Dorsal view of pupa.

Fig. 4.-Oberea ruficollis: Latero-dorsal view of larva. 
PLATE NO. XXXII.
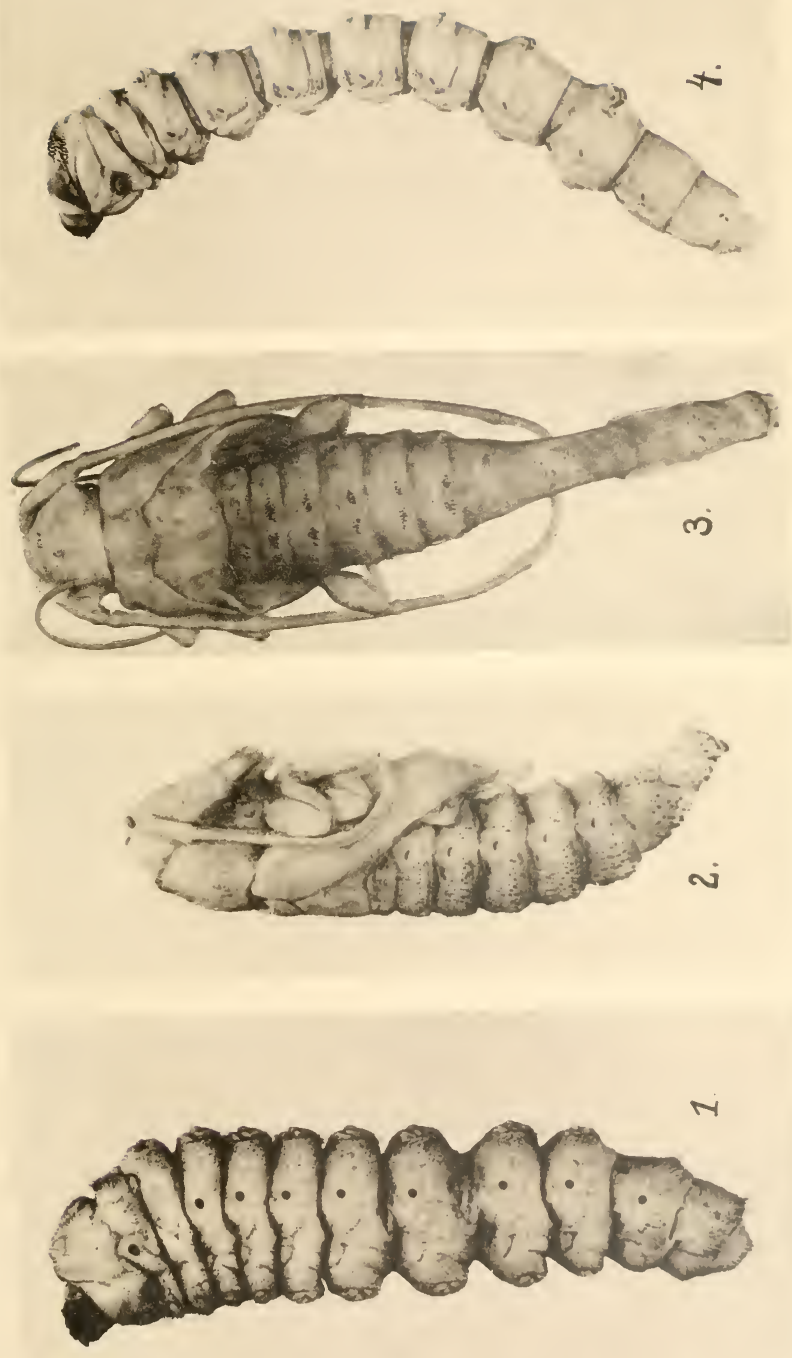


PLATE XXXIII

Work of Cerambycidae

Fis. 1.- Gioes tigrinus: Larval mines in living Quercus alba. Note the open type of mine. Fig. 2.-Mecas pergrata: Larval mines in stem of Aster.

FiG. 3.-Phymatodes varius: Larval mines beneath bark of Quereus alba. 

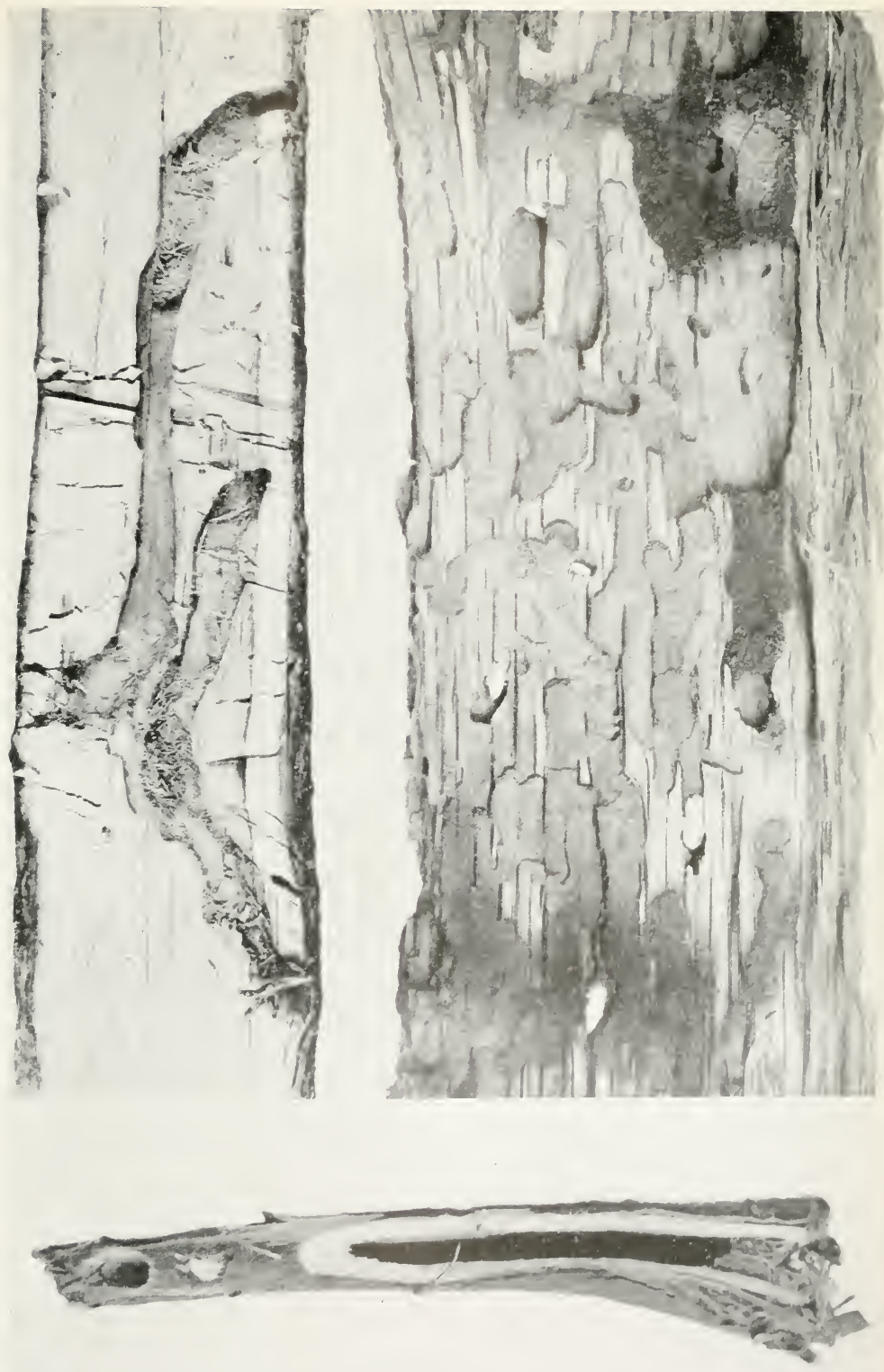
PLATE XXXIV

WORK OF HYLOTRUPES

Larval mines of Hylotrupes amethystinus under bark of Litocens 
PL.ITE No, XXYIV.

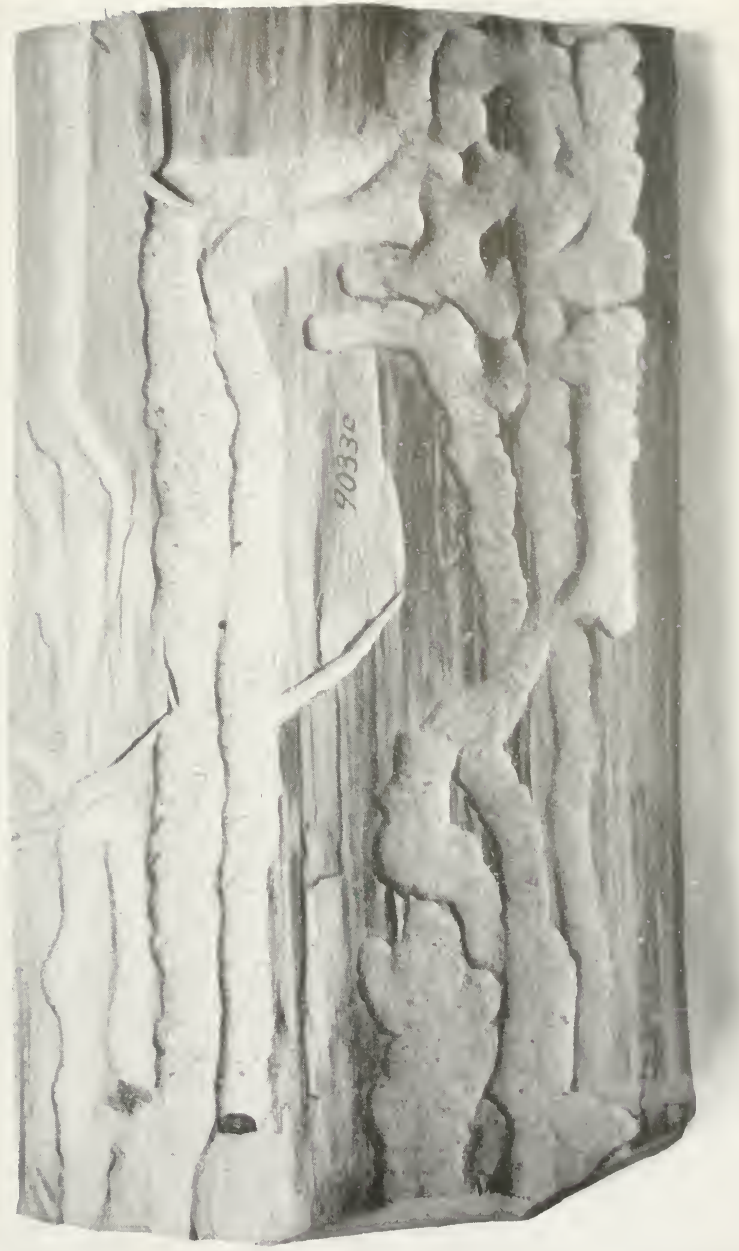




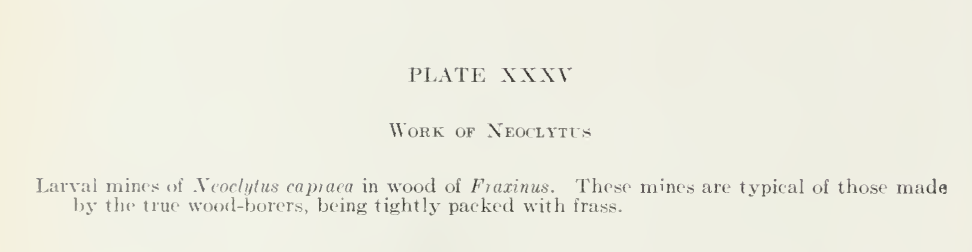


PLATE NO, XXYV

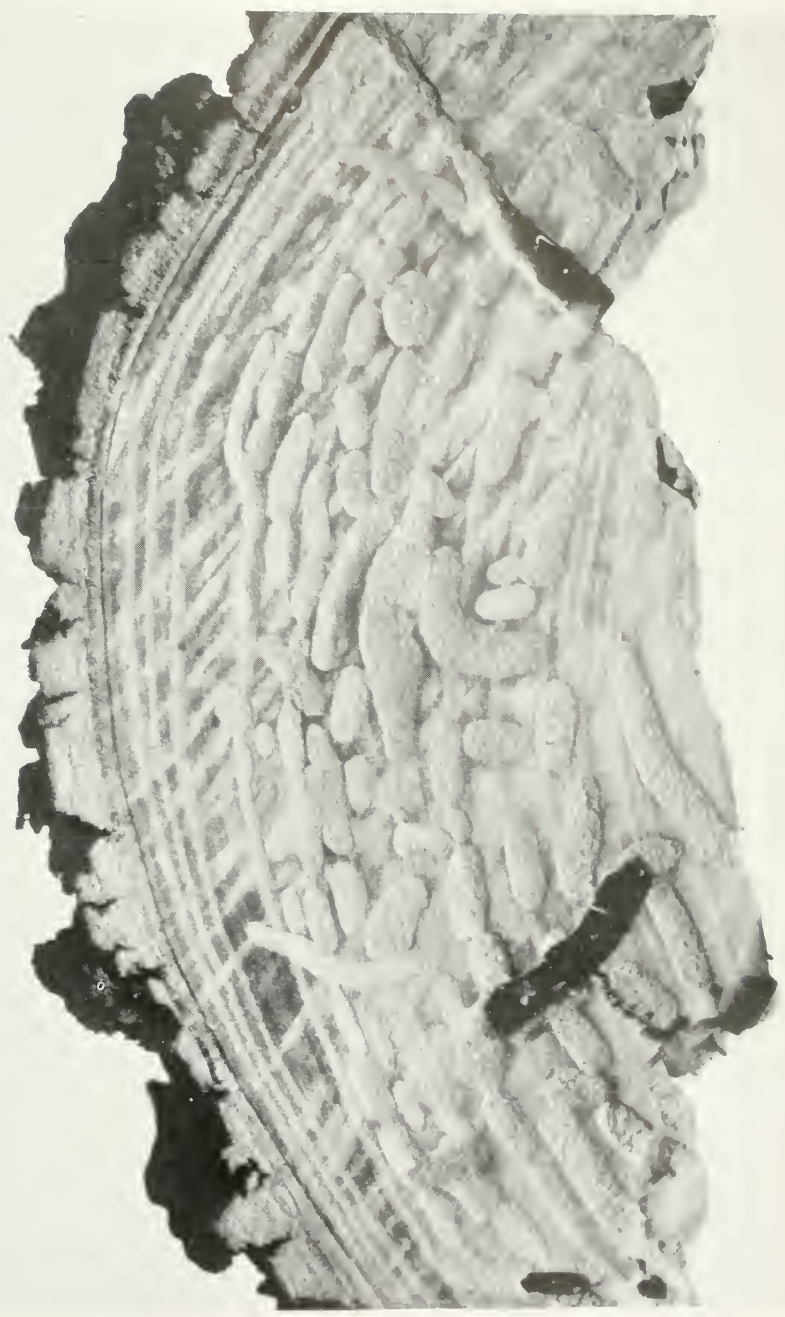




\section{PLATE XXXII}

\section{Eggs and Preptpal Larva of Cerimbycidae}

lig. 1. Prionus laticollis: (iroup of eggs inserted about 1 inch into the ground.

lig. 2.-Prionus californicus: Prepupal larva in earthen cell which it has construeted.

Fici. 3.-Saperda calcarata: View of egg scar from beneath, showing eggs.

Fic. 4. - Saperda calcarata: Egg scar on bark of Populus. 
PLATE No. XXXY

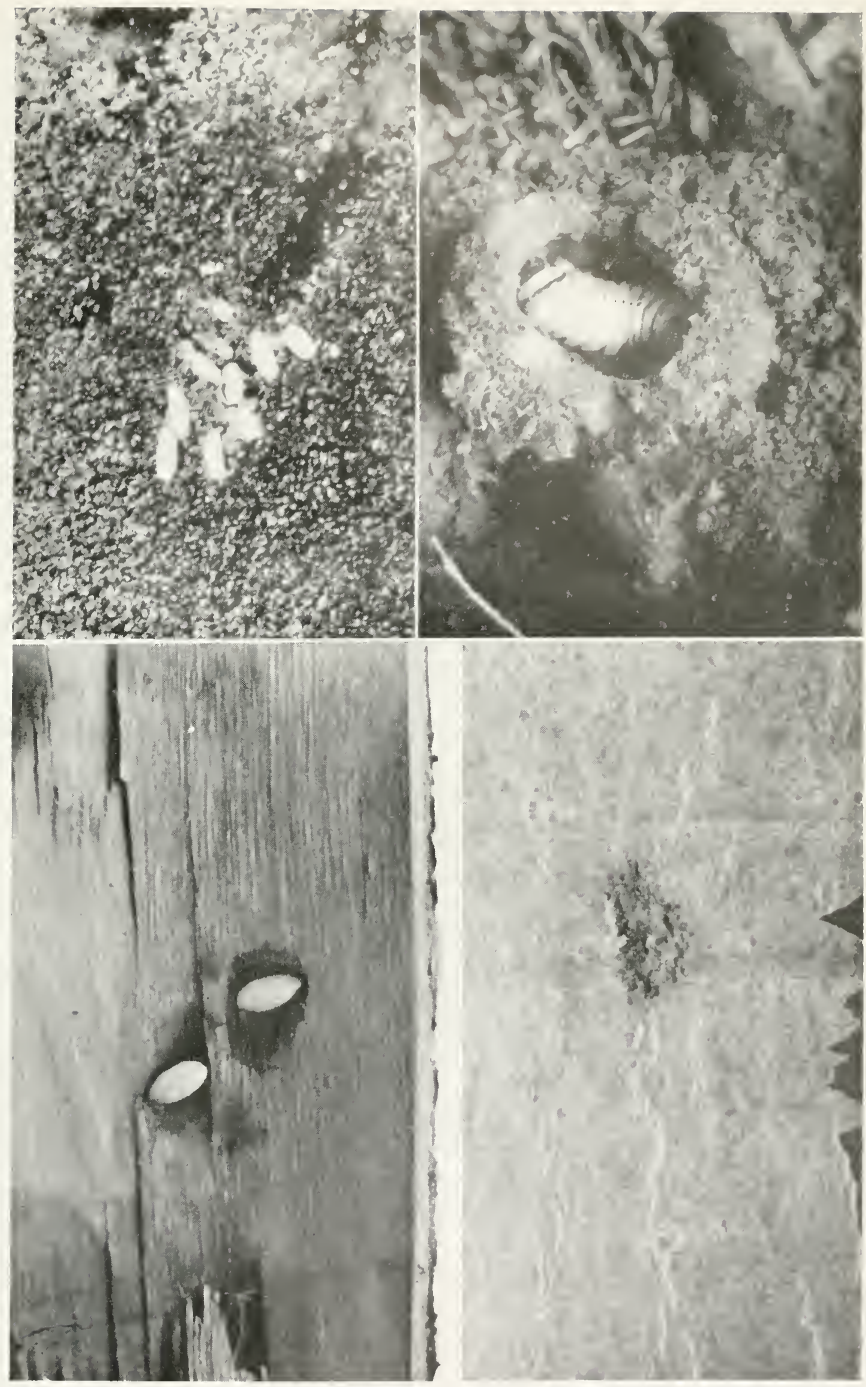


PLATE NXXVII

Work of Leptura

Larval mines of Leptura nitens in bark of c'astanea. 
PLATE Noo, XXXVII

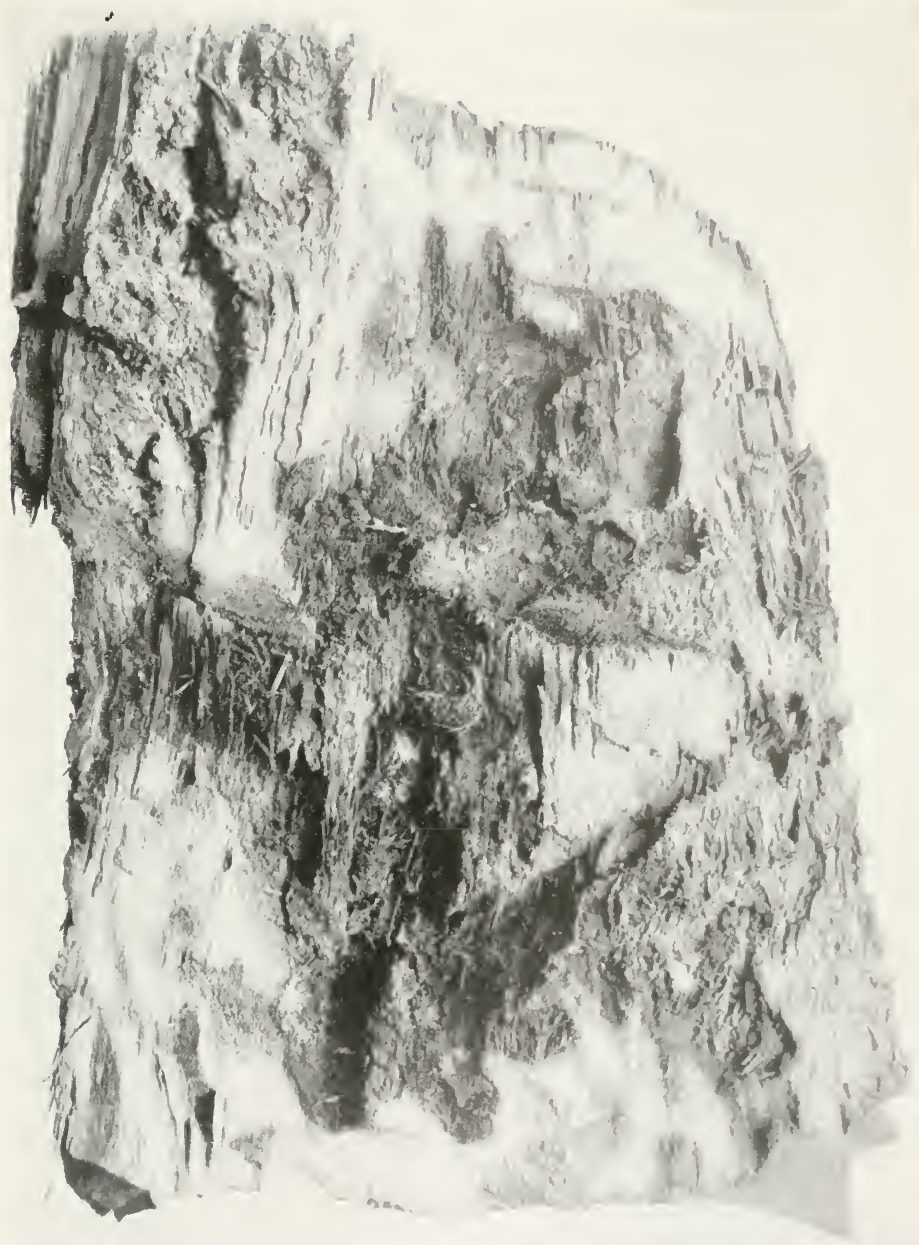




\section{PLATE XXXVII}

WORK OF MONOCHAMUS

Larval mines of Monochamus maculosus under bark of Pinus. Note several plugs of frass where the larvae entered the wood, and fibrous frass. 
PLATE No. XXXviII.

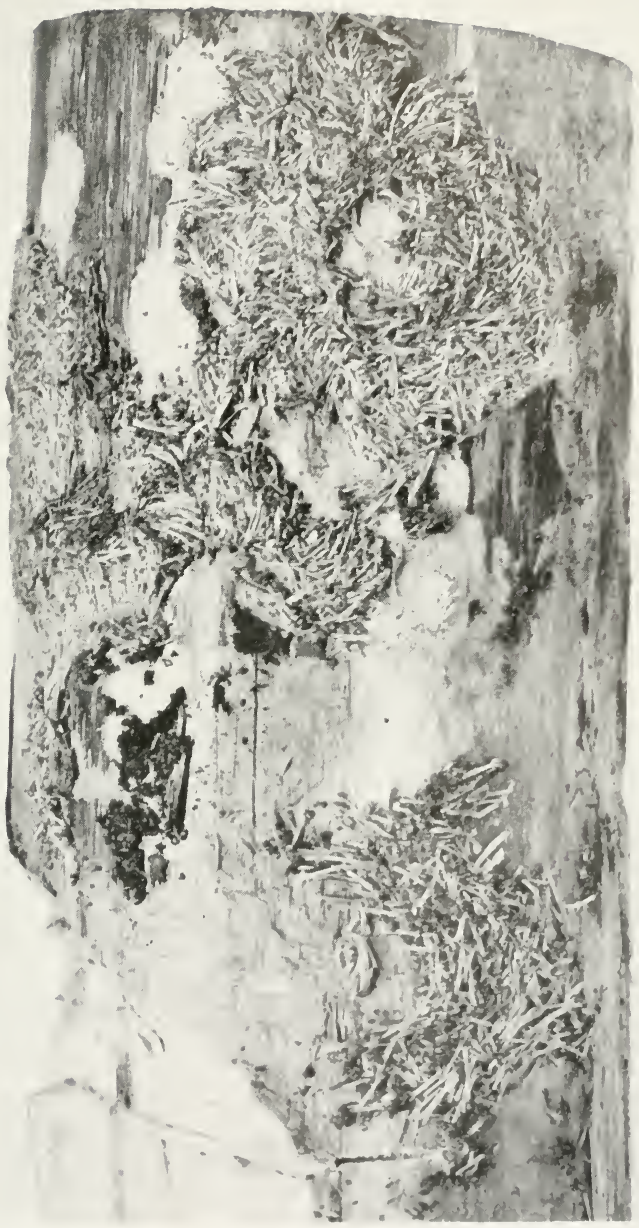




\section{PLATE XXXIX}

\section{WORK OF CERAMBICIDAE}

Frg. 1.-Romalcum rufulum: Larval mines in living Quercus.

FIG. 2.-Oberea ocellata: Branch of sumac girdled by adult when ovipositing.

FIG. 3.-Oberea ocellata: Enlargement of girdle, showing more shallow ring beneath point where egg is placed. 


\section{PLITE No. XXXIX.}

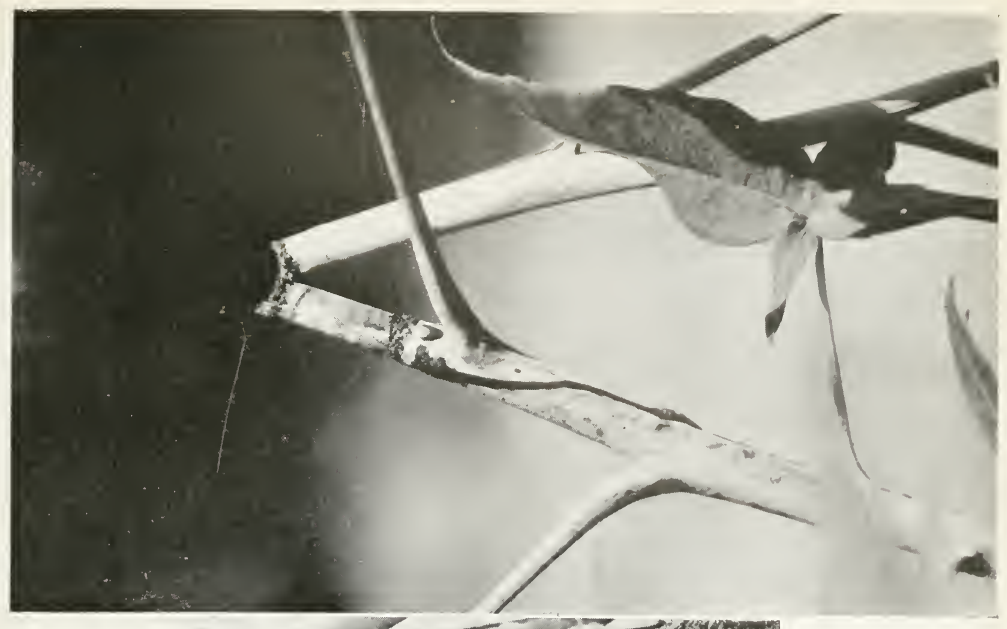

$-12=250$

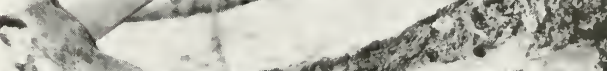

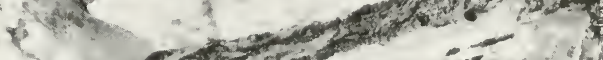

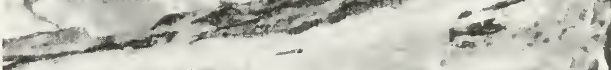

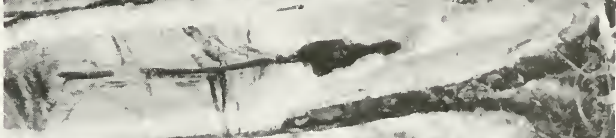

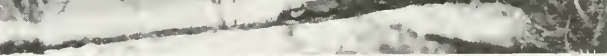

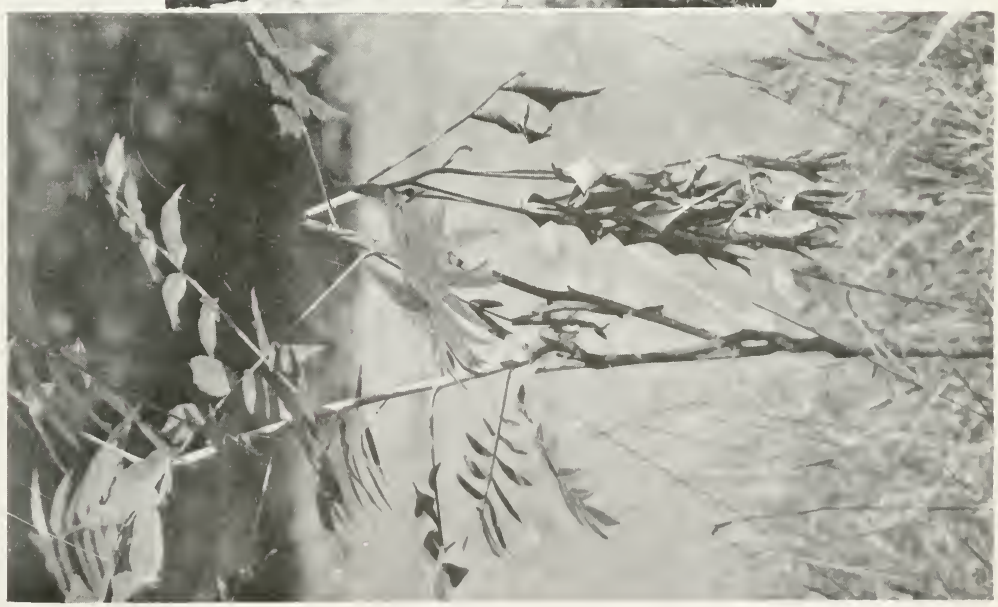




\section{PLATE XL}

\section{WORK of Cerambycid Larvae}

Fig. 1.- Tylotrechus quadrimaculatus: Branch of Fagus cut by larvae.

Fig. 2.- Tylotrechus quadrimaculatus: Branch of Fagus cut by larvae.

Fig. 3.-Goes tigrinus: Frass cxuded from larval mine, showing fibrous type.

Fig. 4.-Romaleum rufulum: Frass exuded from larval mine, showing granular type.

Fig. 5.-Prionoxystus robiniae: Frass exuded from larval mine, showing pellet type, for comparison with that of cerambycid borers. In the case of this and other lepidopterous borers the frass is of this type, thus being readily distinguished from that of all coleopterous borers, so far as known.

Figs. 6 and 7.-Larval mines of Paratimia conieola in cones of Pinus attcnuatus. 

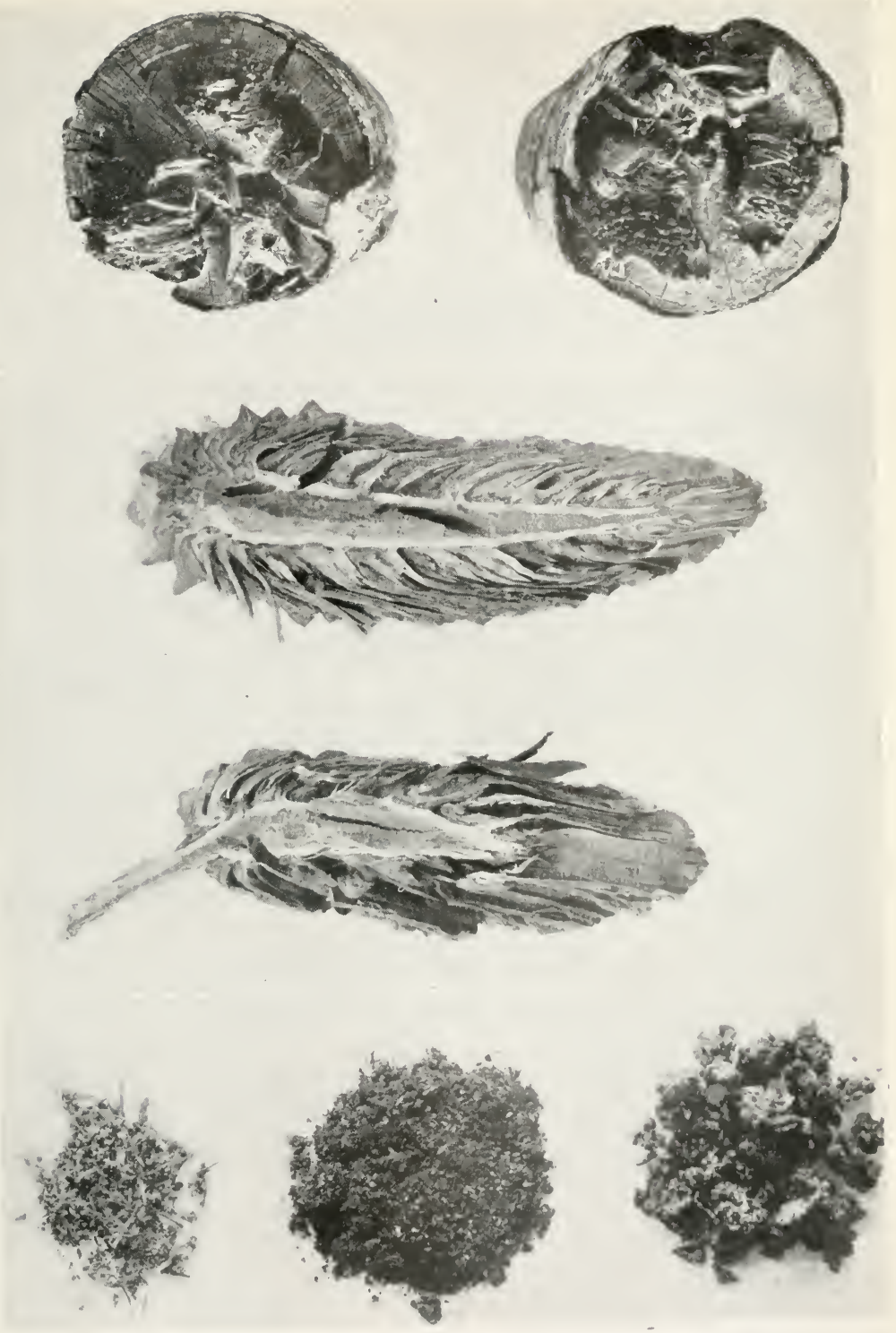


\section{PLATE XLI}

\section{Cerambycid Galls}

Galls of Saperda concolor on twigs of Populus. 
PLATE No. XII.
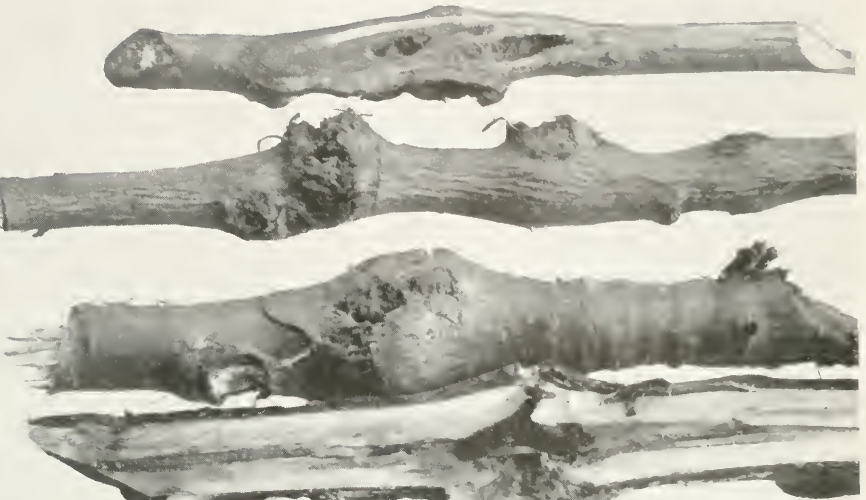

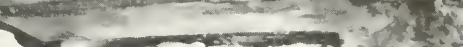

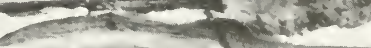

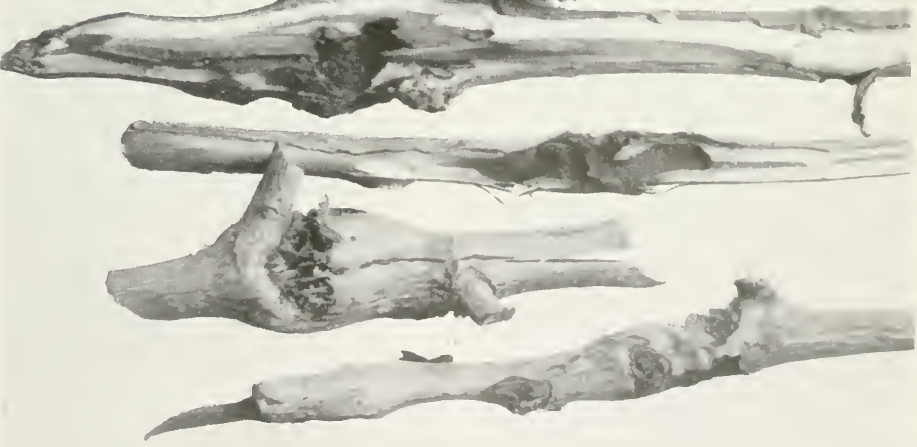




\section{PLATE XLII}

Pupal Cells and Work of Cerambycid Larvae

Fis. 1.-Molorehus bimaeulotus: simple type of pupal cell in sapwood of Cereis. Note the plug of frass in the cell, and that the adult must gnaw only through the bark to eseape.

Fic. 2.-Cyrtinus pygmacus: Simple type of pupal cell under bark in Quereus-merely the wood surface searred.

Fig. 3.-Elaphidion subpubeseens: Peculiar series of holes in girdled branch of Quereus for exudation of frass. Note type of eut where twig is girdled.

FIG. 4.-Ela phidion subpubescens: Pupal cell in Castanea dentata made by two wads of frass.

FIG. 5.-Elaphidion sp. (9901q): Type of eut made by this girdler on twigs of Thurberia.

FIG. 6.-Rhagium. lineatum: A more elaborate type of pupal cell made of fibrous frass beneath the bark of Pinus.

Fig. 7.-Arhopalus fulminans: Angular type of pupal cell in Castanea dentata. The pupal eell is cpen to the exterior except for the wad of frass.

Fig. S.-Oeme rigida: Pupal eell in Juniperus. This is a rather elaborate type, rarely seen in the ecrambyeids.

Fig. 9.-Hylotrupes ligneus: Simple type of pupal eell in sapwood of Juniperus. Note wad of granular frass projecting from the surfaee of the sapwood. Compare with figure 1 . 
PLATE No. XLII.
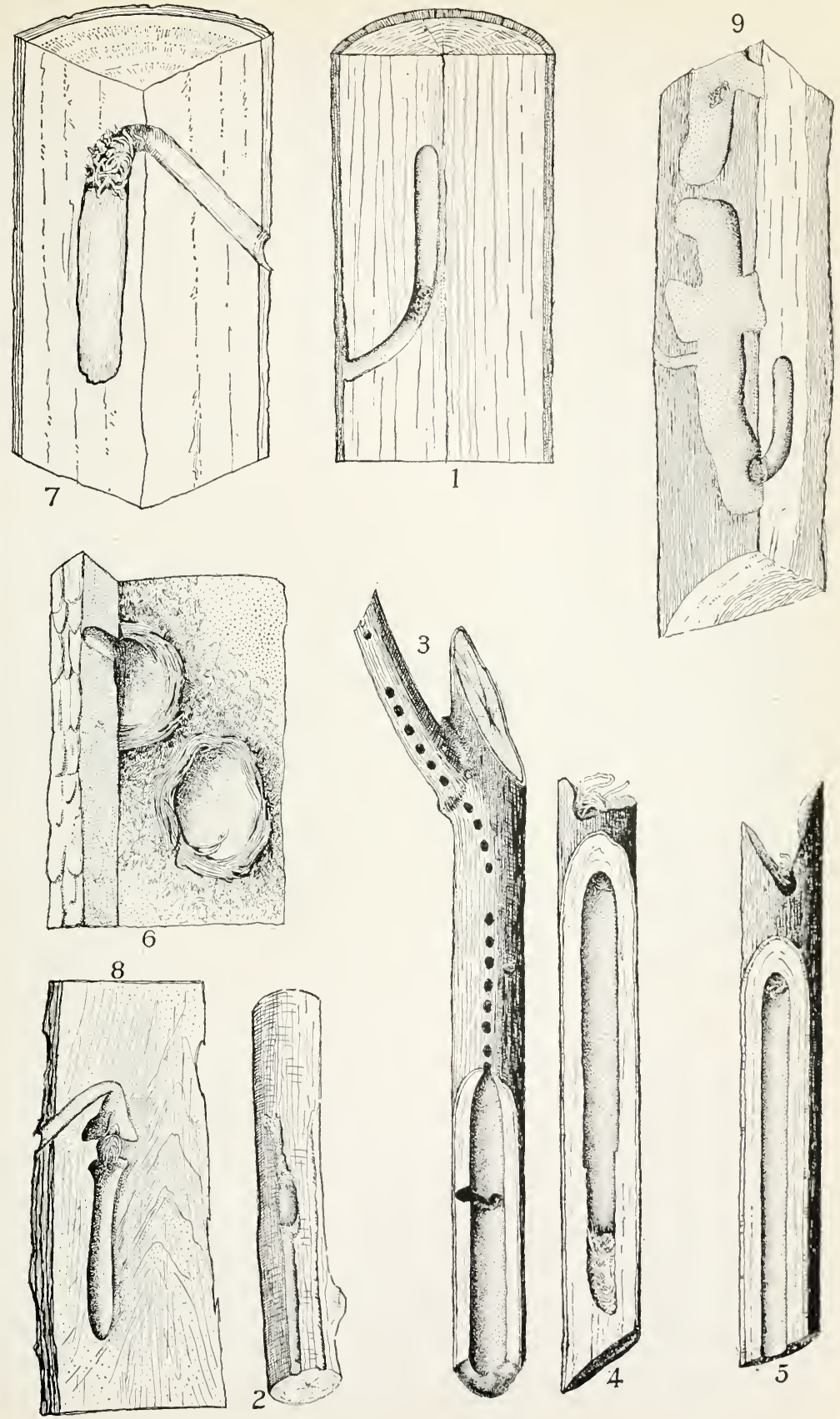


\section{PLATE XLIII}

\section{Diagramiatic Figures to Illustrate Pupal Cells of Cerambycidae}

Fig. 1. Mono hamus scutellatus: Pupal cell in Pinus. Note the plugred entrance into the wood, the curved type of cell, and the fact that the adult will gnaw through the wood to escape.

FIG. 2.-Romaleum rufulum: Pupal cell in Quercus. Note that the plug is below the pupa and that the larva has opened an exit hole to the bark.

FIg. 3.-Goes tigrinus: Pupal cell in Quercus alba, showing the plug behind the larva. The adult must gnaw through the wood to escape. 


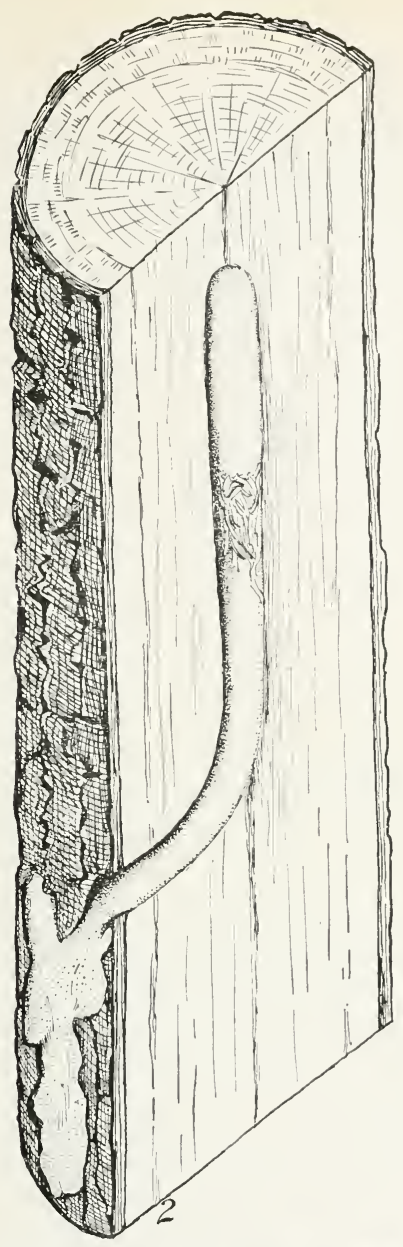

PLATE No. XLIII.
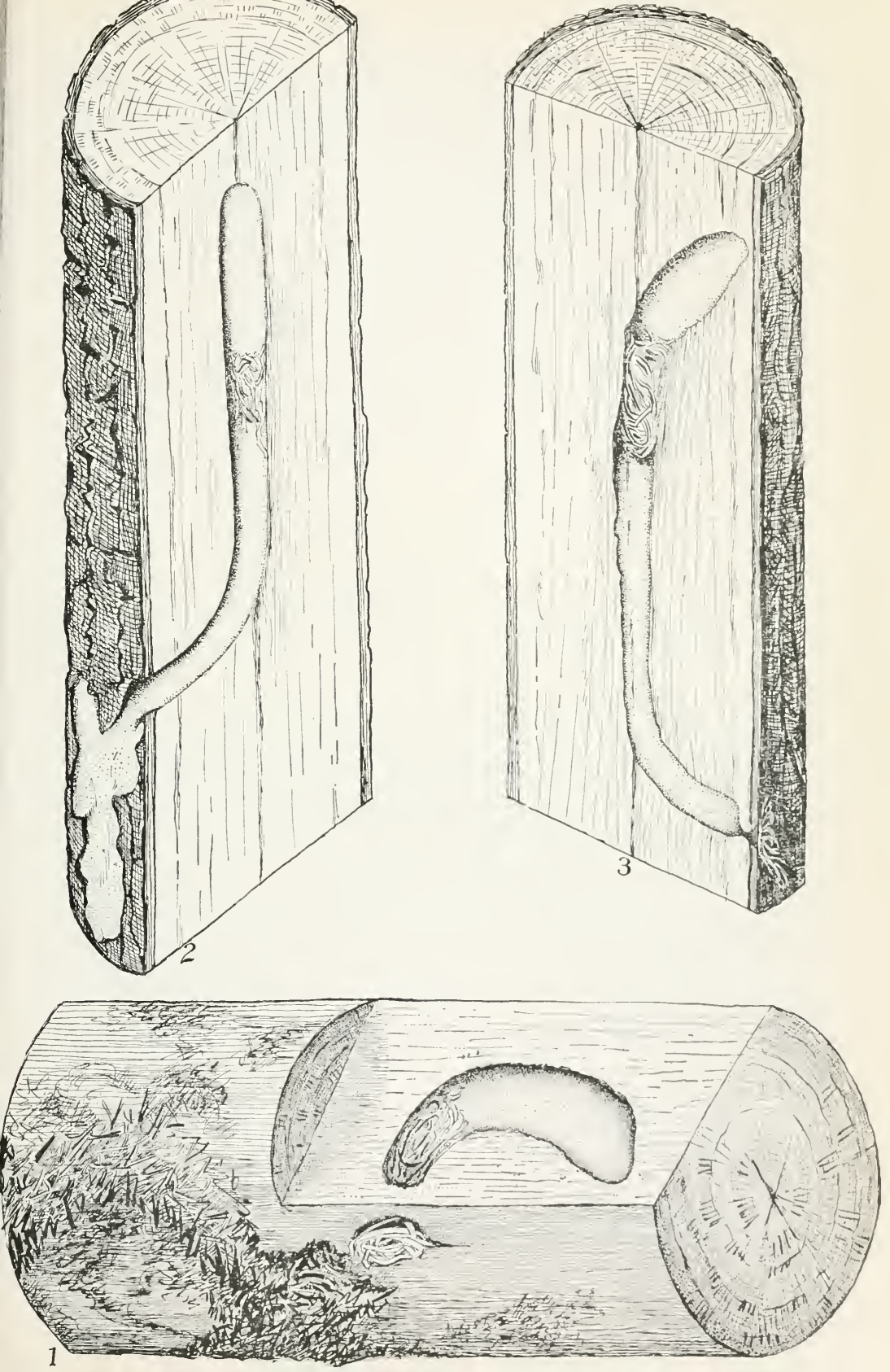
PLATE XIIV

Feeding by Adults of Cerambycidae

FIG. 1.- Saperda discoides: Feeding of adult on hickory leaves.

FIG. 2.-Goes pulverulenta: Feeding of adult on twigs of ironwood.

Fig. 3.-Romaleum sp.: Pupal cells and healed scars from old pupal cells on white oak. These scars are very common on large mature oaks. 
PLATE No. XLIV,
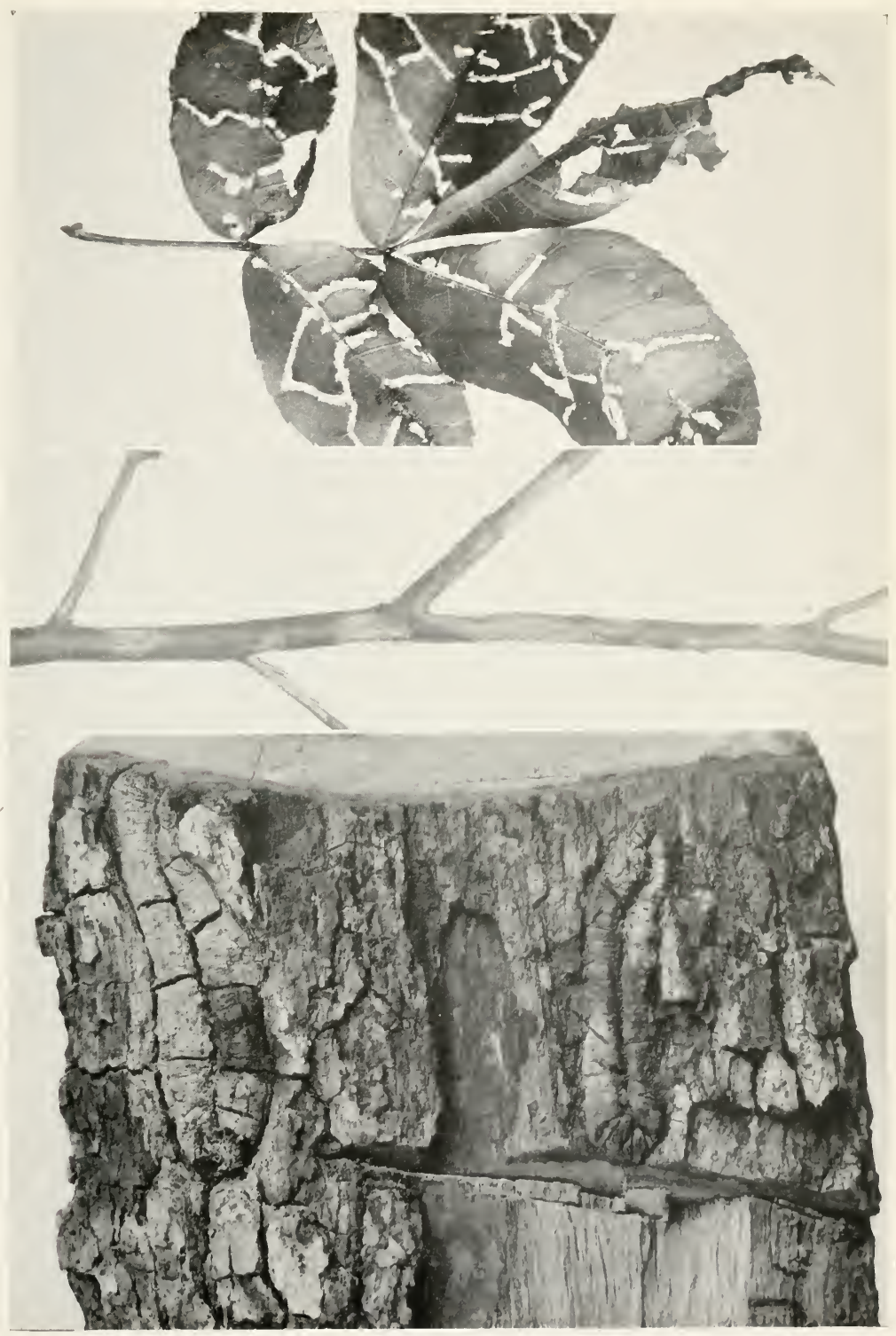
$1059 \quad 4$

18 






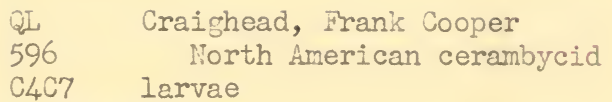

\title{
$\mathrm{ESCl}$
}

\author{
PLEASE DO NOT REMOVE \\ CARDS OR SLIPS FROM THIS POCKET
}

UNIVERSITY OF TORONTO LIBRARY 


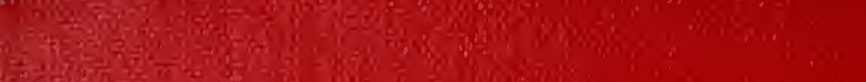
incosing a

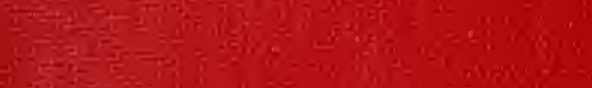

